2008

\title{
Significance Testing of Site 41SS164, San Saba County, Texas
}

\author{
Mindy L. Bonine \\ Michael R. Chavez \\ Charles Frederick
}

Follow this and additional works at: https://scholarworks.sfasu.edu/ita

Part of the American Material Culture Commons, Archaeological Anthropology Commons, Environmental Studies Commons, Other American Studies Commons, Other Arts and Humanities Commons, Other History of Art, Architecture, and Archaeology Commons, and the United States History Commons

Tell us how this article helped you.

This Article is brought to you for free and open access by the Center for Regional Heritage Research at SFA ScholarWorks. It has been accepted for inclusion in Index of Texas Archaeology: Open Access Gray Literature from the Lone Star State by an authorized editor of SFA ScholarWorks. For more information, please contact cdsscholarworks@sfasu.edu. 


\section{Significance Testing of Site 41SS164, San Saba County, Texas}

\section{Licensing Statement}

This is a work for hire produced for the Texas Department of Transportation (TxDOT), which owns all rights, title, and interest in and to all data and other information developed for this project under its contract with the report producer. The report may be cited and brief passages from this publication may be reproduced without permission provided that credit is given to TXDOT and the firm that produced it. Permission to reprint an entire chapter, section, figures or tables must be obtained in advance from the Supervisor of the Archeological Studies Branch, Environmental Affairs Division, Texas Department of Transportation, 125 East 11th Street, Austin, Texas, 78701. 
TxDOT CSJ Number: 0923-25-014

\author{
Prepared for \\ TEXAS DEPARTMENT OF TRANSPORTATION \\ Environmental Affairs Divison \\ 125 East $11^{\text {th }}$ Street \\ Austin, Texas 78701-2483
}

Prepared by

Mindy L. Bonine, Michael R. Chavez, and Charles Frederick

\author{
SWCA ENVIRONMENTAL CONSULTANTS \\ 4407 Monterey Oaks Blvd. \\ Building 1, Suite 110 \\ Austin, Texas 78749 \\ www.swca.com
}
Principal Investigator
Kevin A. Miller

Texas Antiquities Permit 4156

SWCA Project Number 12910-192-AUS

SWCA Cultural Resources Report No. 2007-537

February 1, 2008 


\section{SIGNIFICANCE TESTING OF SITE 41SS164, SAN SABA COUNTY, TEXAS}

Copyright $(\mathcal{C} 2007$

Texas Department of Transportation (TxDOT) and SWCA, Inc.

TxDOT and SWCA, Inc., jointly own all rights, title, and interest in and to all data and other information developed for this project under Contract 577XXSA002. Brief passages from this publication may be reproduced without permission provided that credit is given to TxDOT and SWCA, Inc. Permission to reprint an entire chapter, section, figures, or tables must be obtained in advance from the Supervisor of the Archeological Studies Program, Environmental Affairs Division, Texas Department of Transportation, 125 East $11^{\text {th }}$ Street, Austin, Texas 78701. Copies of this publication have been deposited with the Texas State Library in compliance with the State Depository requirements.

Printed by Ginny’s+Merit, Austin, Texas.

jointly published by the

Texas Department of Transportation

Environmental Affairs Division

Archaeological Studies Program

Scott Pletka, Ph.D., Supervisor

Archeological Studies Program, Report No. 105

A. McGraw, Series Editor

and

SWCA, Inc.

Austin, Texas

SWCA Cultural Resources Report No. 2007-537

Texas Antiquities Permit 4156

ISBN: 1-930788-74-6 


\begin{abstract}
SWCA Environmental Consultants (SWCA) conducted significance testing excavations at site 41SS164, San Saba County, Texas on behalf of the Texas Department of Transportation (TxDOT). The tested portion of the site is in TxDOT's right-of-way (ROW) of County Road (CR) 228 on the eastern bank of Richland Springs Creek, a tributary of the San Saba River. SWCA performed the investigations under General Services Contract \#575XXSA007, Work Authorization \#575 21 SA007, and Texas Antiquities Permit 4156. The final report was written under General Services Contract \#577XXSA002, Work Authorization \#577 05 SA002.
\end{abstract}

In the course of the investigations, SWCA conducted backhoe trenching, hand excavations, special sampling, and other documentation at the project area. As the ROW on the eastern side of the CR 228 bridge is extremely narrow, all trench and hand excavations were conducted in the roadway after the removal of the gravel roadbed and several layers of fill. In all, approximately $3 \mathrm{~m}^{3}$ were excavated by hand at the site, beginning at the transition point between the fill layers and layers containing cultural material, or just above it. In addition to the hand excavations, the testing project included two backhoe trenches excavated perpendicular to each other. As an additional element of the investigations, SWCA excavated one 50-x-50-cm column sample to assess the site's potential artifact recovery and potential cultural layers.

The testing determined that the site contains one intact cultural component, designated Analytical Unit 1 (AU 1), in an alluvial setting. A second deposit containing cultural material above AU 1 was determined to be part of an ambiguous interface fill deposit and not an in situ component. AU 1 contains two burned sandstone rock features, debitage, bone, a dart point, lithic tools, and two charcoal samples. The radiocarbon samples yielded widely disparate dates; one is interpreted as an intrusive sample, and the other found in Feature 2 dated to the Late Archaic. A Pandale dart point dating to the Early/Middle Archaic (8,800-4,000 B.P.) was also found in Feature 2 within AU 1. The deposits appeared to be highly compressed. Geomorphological investigations of the east-west backhoe trench revealed a steady downward slope of cultural material in both AU 1 and the ambiguous interface fill deposit as one approached Richland Springs Creek. Thus, although cultural material was encountered at various depths within the site area, it was identified as one cultural component. Artifact recovery was sparse, with modest amounts of organic material preserved.

Although the site contains one analytical unit with prehistoric cultural material in an observable natural stratum, the sloping stratigraphy and complex soil deposition makes it difficult to subdivide the component into more than one occupation period subject to specific research questions. Geomorphic analysis suggests a level of compression in the component. Additionally, the quantity and diversity of cultural material recovered from the site indicates the potential data yield to answer specific research questions is marginal. SWCA recommends that the portion of 41SS164 within the road ROW is not eligible for National Register of Historic Places (NRHP) listing under Criterion D, 36 CFR 60.4, and is not eligible for State Archeological Landmark (SAL) designation under Criteria 1 and 2 of the Rules of Practice and Procedure for the Antiquities Code of Texas, 13 TAC 26.8. Data recovery investigations are not recommended for the portion of the site within the ROW. Portions of the site outside of the ROW have not been fully evaluated. 


\section{TABLE OF CONTENTS}

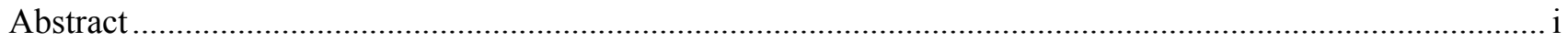

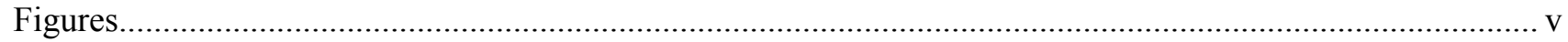

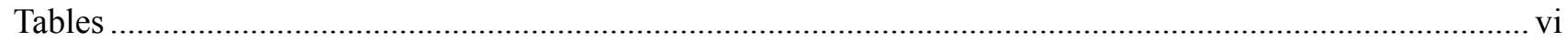

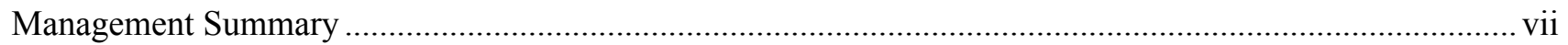

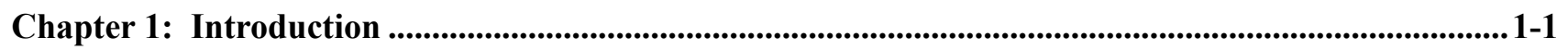

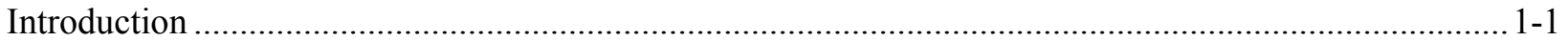

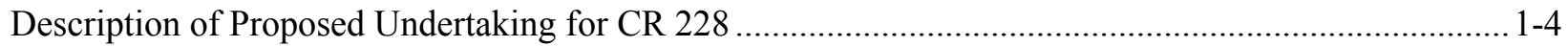

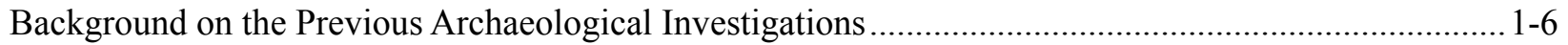

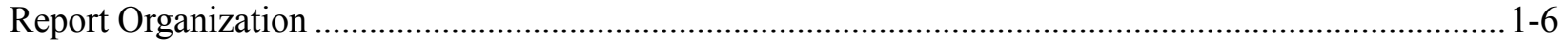

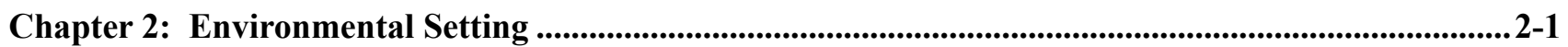

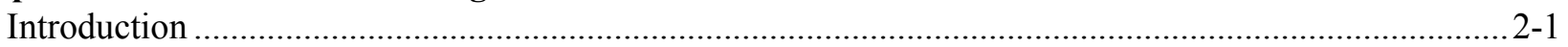

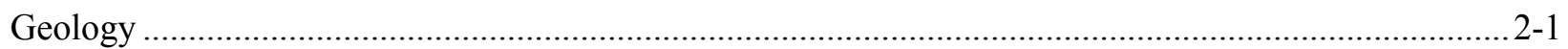

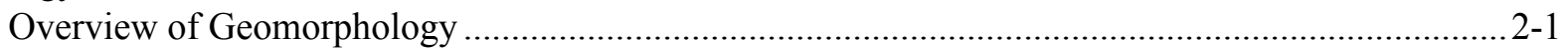

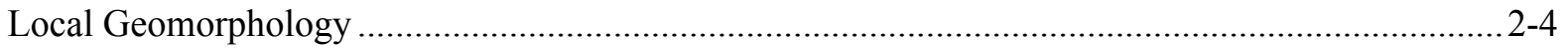

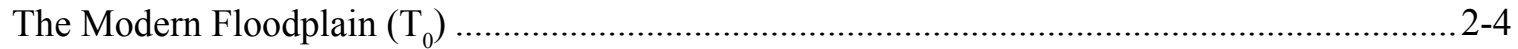

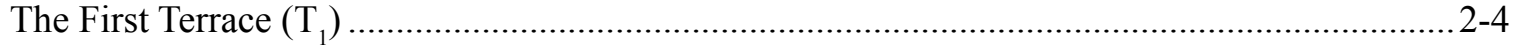

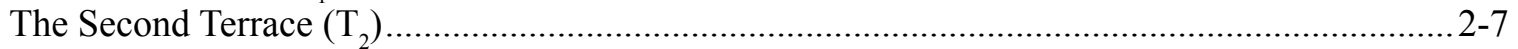

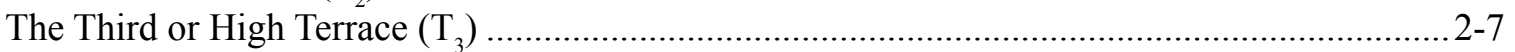

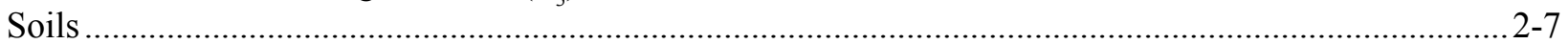

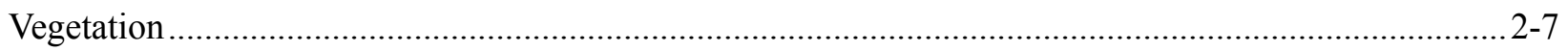

Fauna

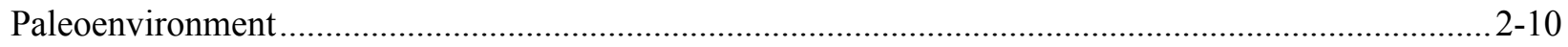

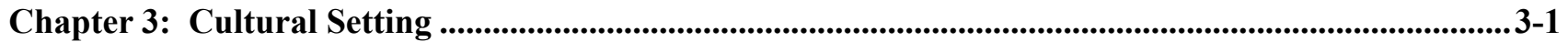

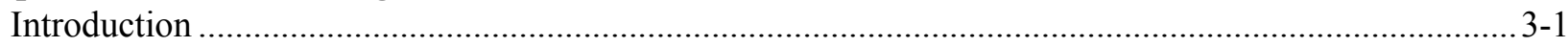

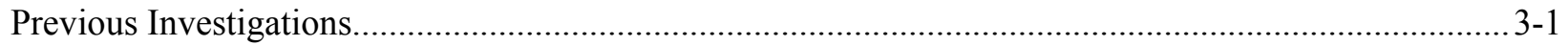

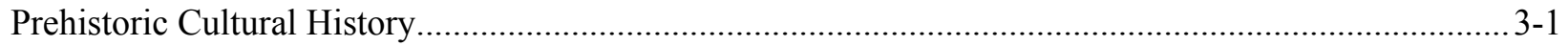

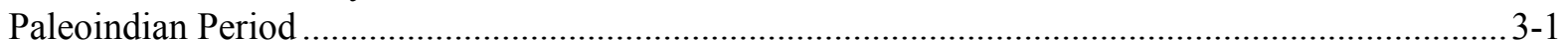

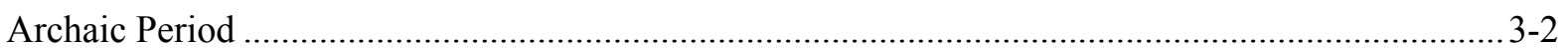

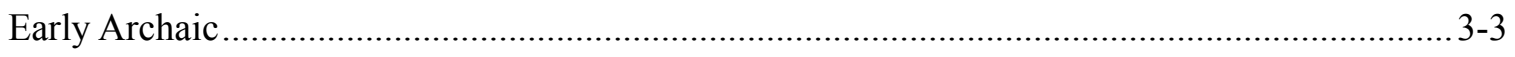

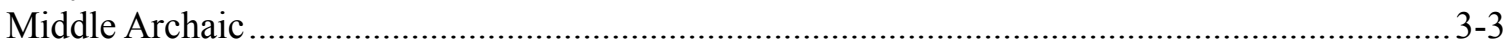

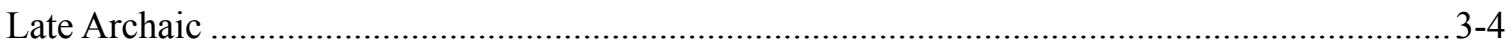

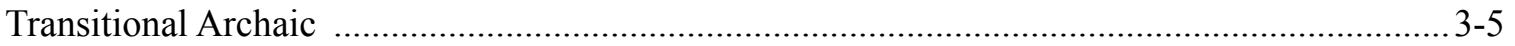

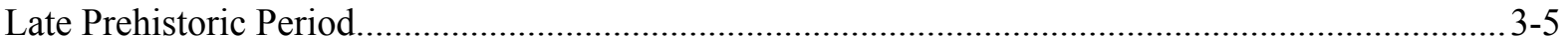

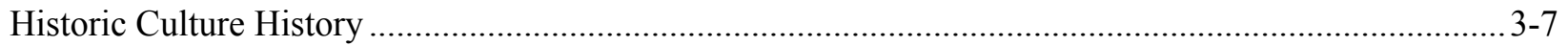

Spanish Colonial/Mexican Independence Period (1630-1820s) .................................................. 3-7

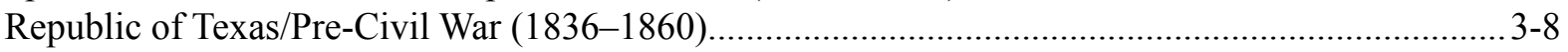

The Post-Civil War to Early Twentieth Century (1865-1920)...................................................... 3-8

Depression Era to Post-World War II (1930-1950s) .................................................................... 3-9

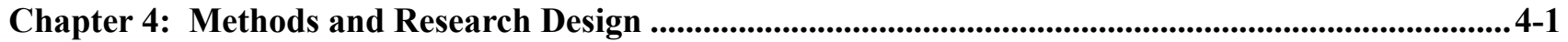

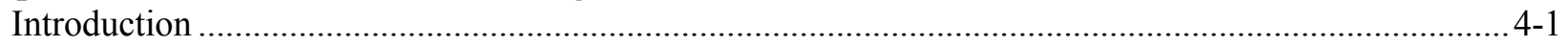

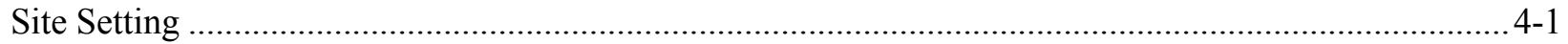

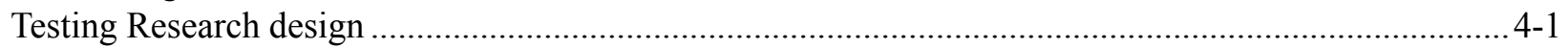

Research Issue 1: Integrity of the Archaeological Deposits ....................................................... 4-1

Research Issue 2: Potential Data Yield ........................................................................................ 4-1 


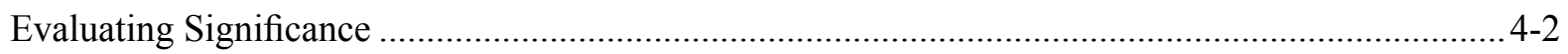

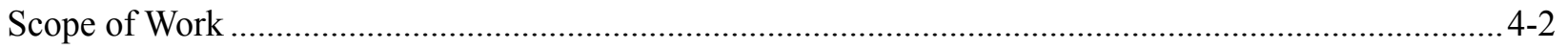

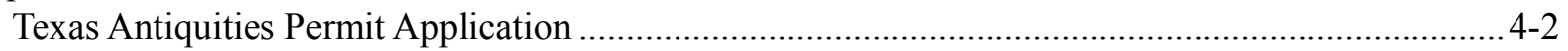

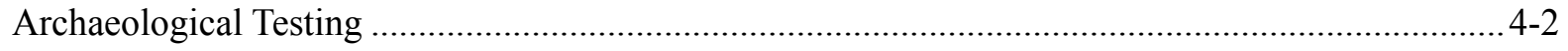

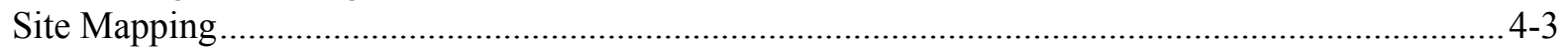

Artifact Collection and Special Samples …............................................................................... 4-3

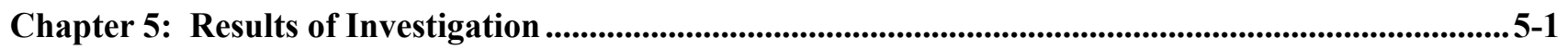

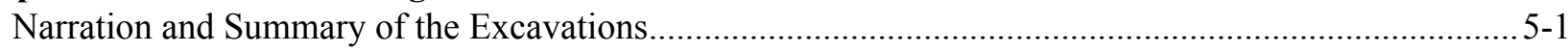

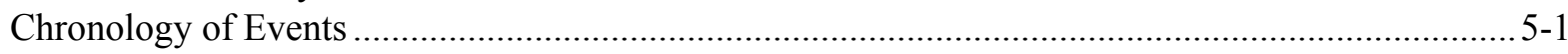

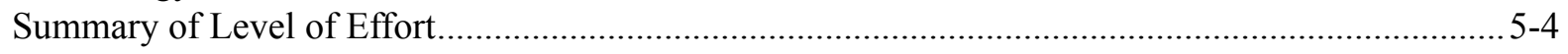

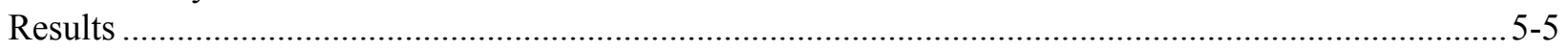

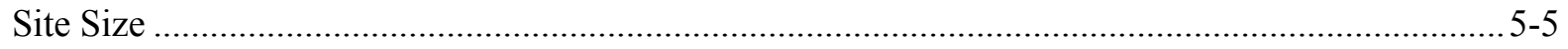

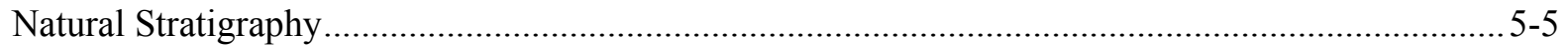

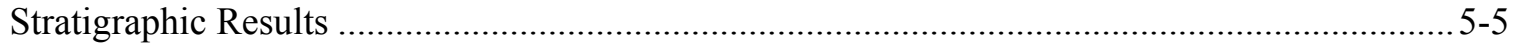

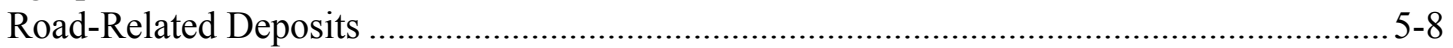

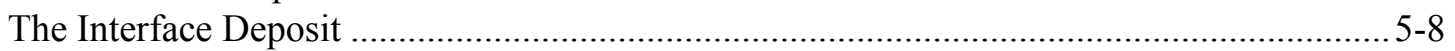

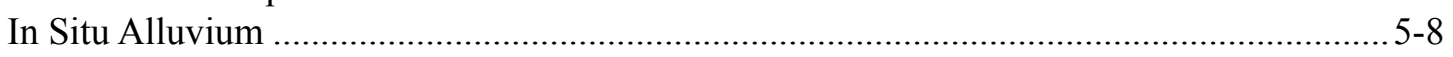

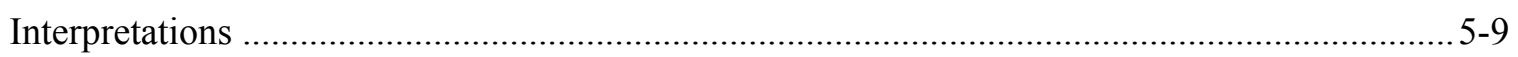

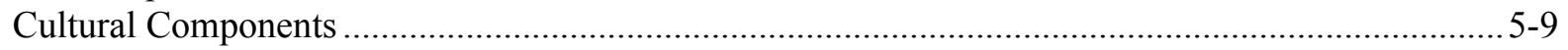

Disturbed Cultural Component ….............................................................................. 5-10

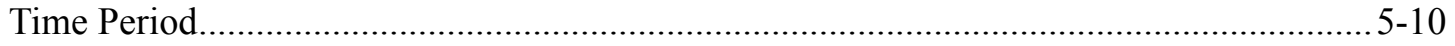

Stratigraphic Position and Vertical Limits .................................................................... 5-10

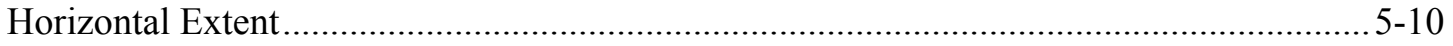

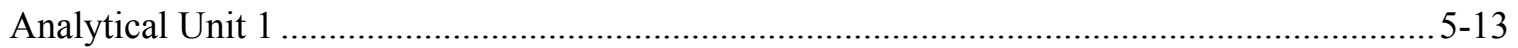

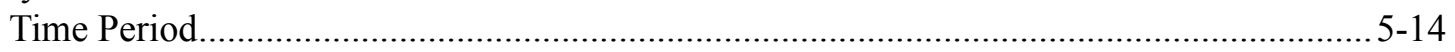

Stratigraphic Position and Vertical Limits ................................................................ 5-14

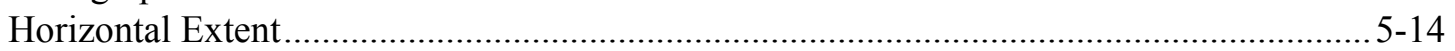

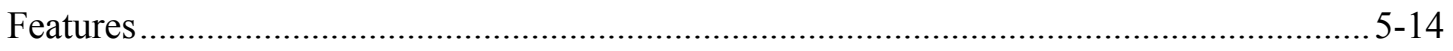

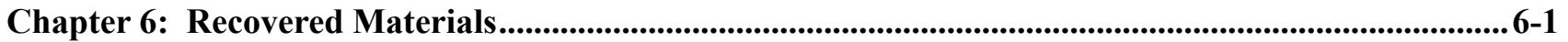

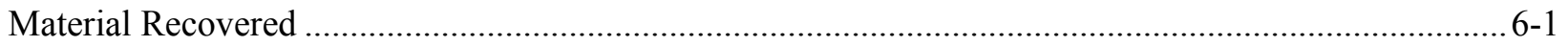

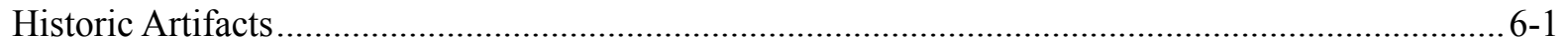

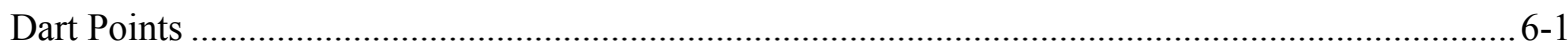

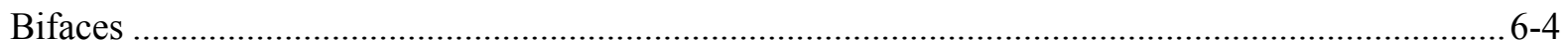

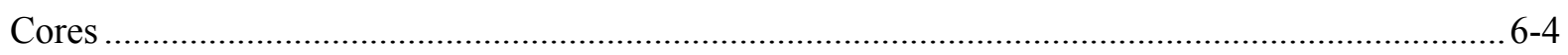

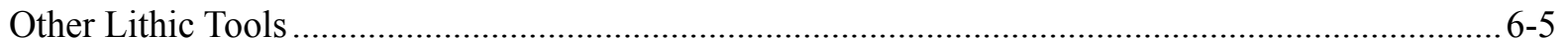

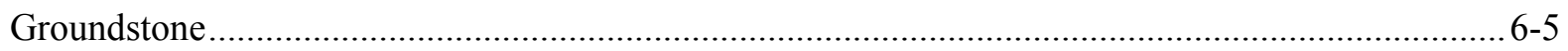

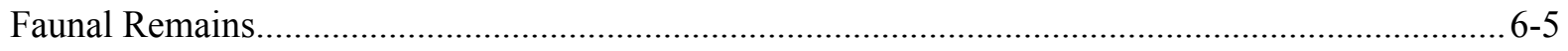

Special Samples

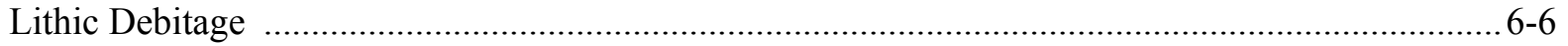

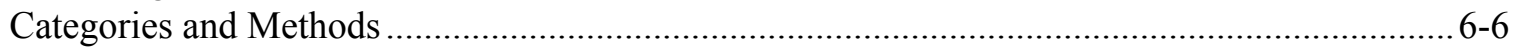

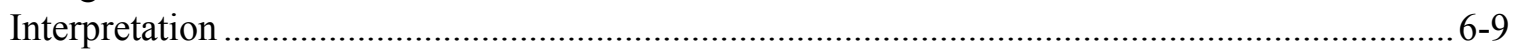

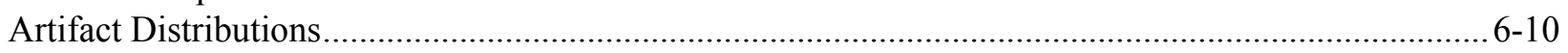

Chapter 7: Data Set for Comparative Literature Review ..................................................................7-1

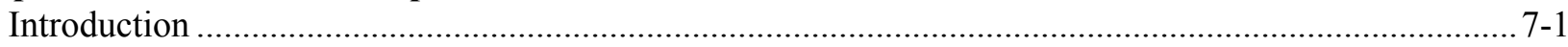

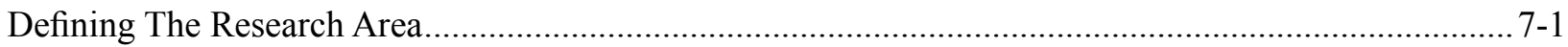

Archaeological Sites in Mesquite Plains, Lampasas Cut Plains, and the Llano Uplift Research Area......7-3

"Tested" Archaeological Sites in The Tri-county Research Area.......................................................... 7-5 


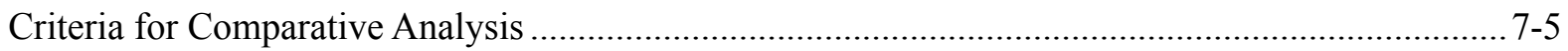

Summary of Tested Sites Found Within the Tri-County Area ...................................................... 7-12

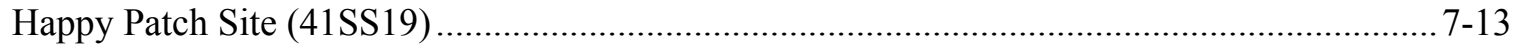

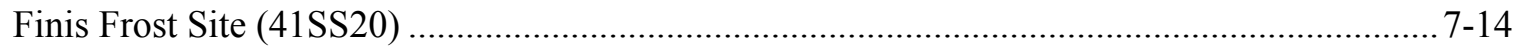

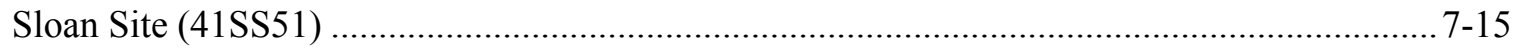

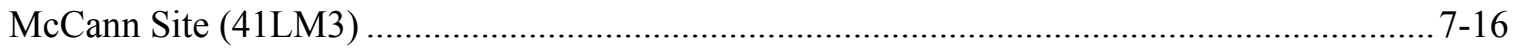

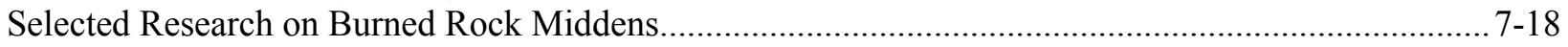

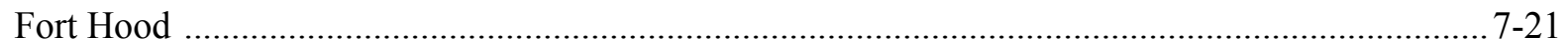

Four Burned Rock Midden Sites on the Greater Edwards Plateau............................................... 7-23

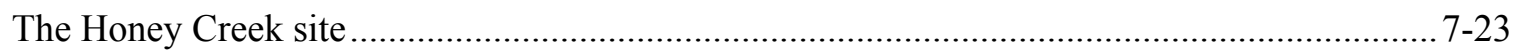

The Corn Creek Sites ................................................................................................. 7-24

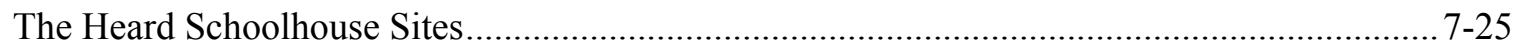

Four Burned Rock Midden Sites Interpretation .............................................................

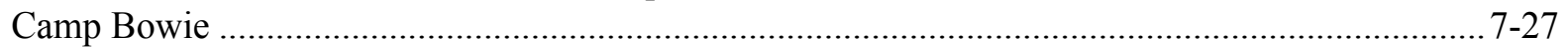

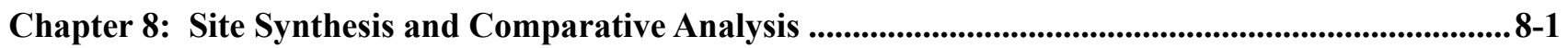

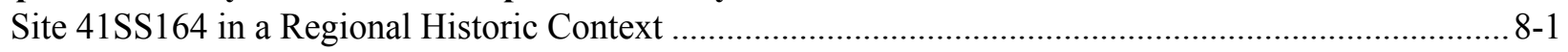

Patterns in Previously Recorded Sites .............................................................................. 8-1

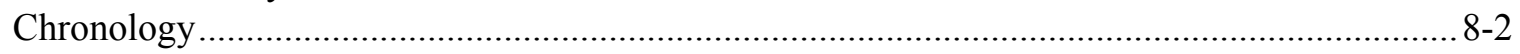

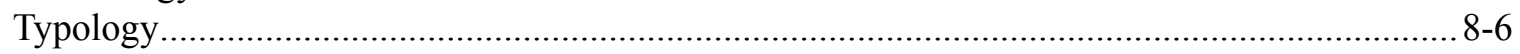

Patterns in Tested Archaeological Sites ........................................................................... 8-10

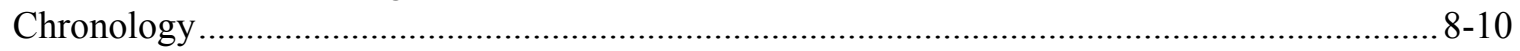

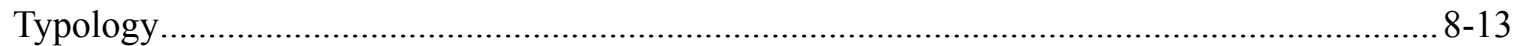

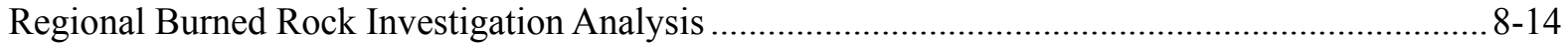

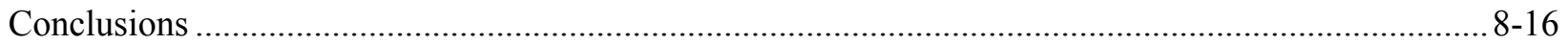

Chapter 9: Summary, Conclusions, and Recommendations......................................................................9-1

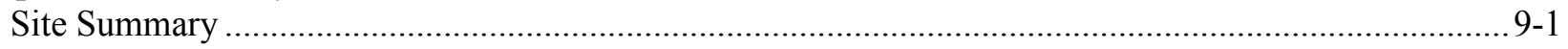

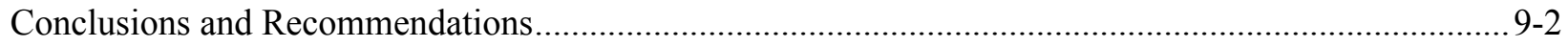

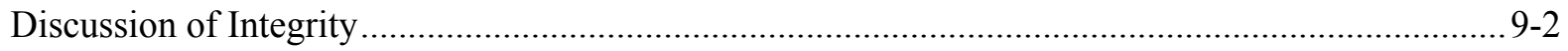

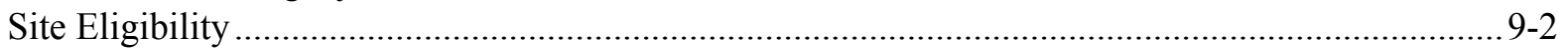

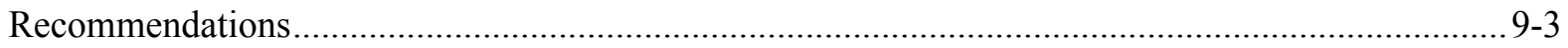

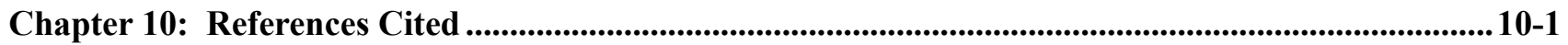

\section{Appendix A: Materials Recovered}

Appendix B: Radiocarbon Results

Appendix C: Macrobotanical Results

Appendix D: Specimen Inventory 


\section{Figures}

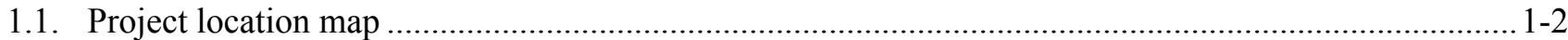

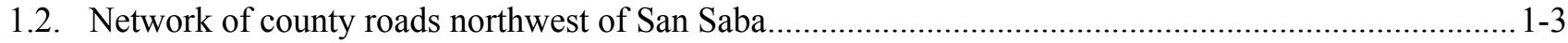

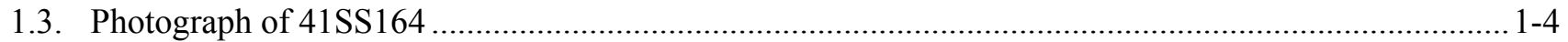

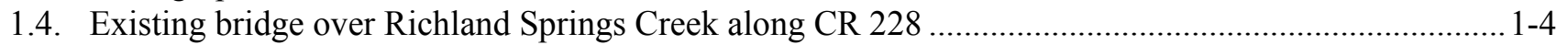

1.5. Proposed concrete slab replacement bridge and site location ..................................................... 1-5

2.1. Natural Regions of Texas, with the location of site 41 SS164 .......................................................2-2

2.2. Geology of San Saba County and the San Saba River Valley ..........................................................2-3

2.3. Local geomorphology of the area around Richland Springs Creek................................................2 2-5

2.4. Location of terraces around Richland Springs Creek .............................................................. 2-6

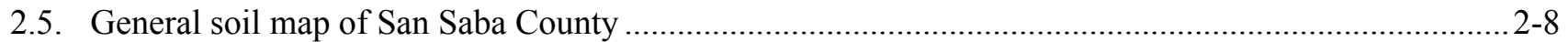

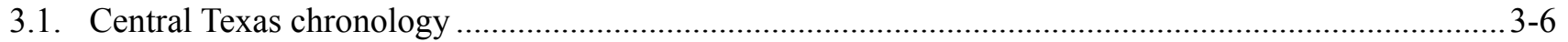

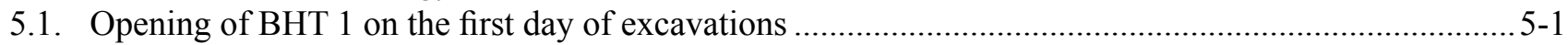

5.2. Location of backhoe trenches and excavation units during testing of $41 \mathrm{SS} 164$................................. 5-2

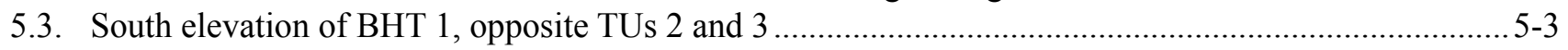

5.4. Clearing of the roadbed on the north side of BHT 1 prior to hand excavations ...................................5-4

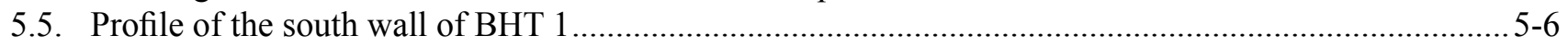

5.6. Profile of the south wall of BHT 1 with details of the cultural components ..................................... 5-11

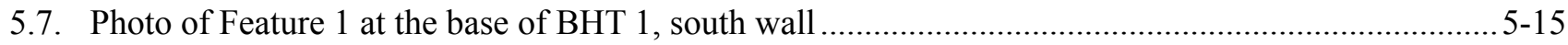

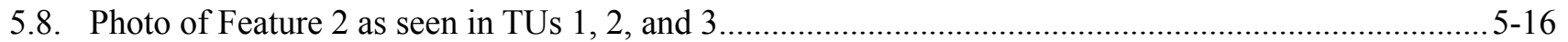

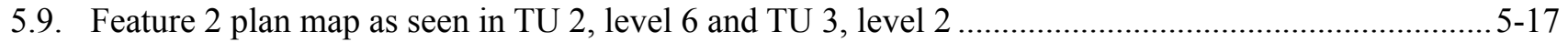

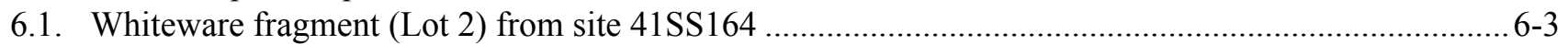

6.2. Pandale projectile point (Lot 18) from site 41SS164 ................................................................. 6-3

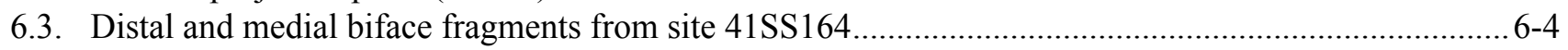

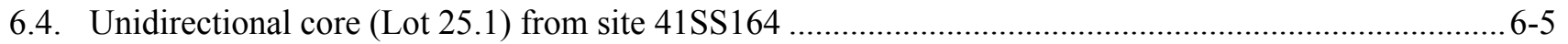

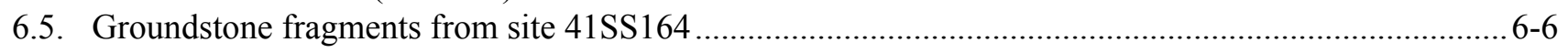

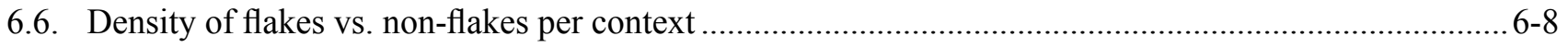

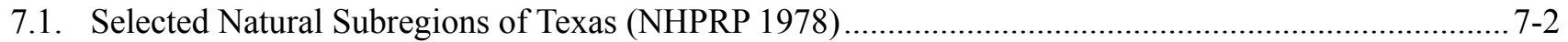

7.2. Close-up of the tri-county research area, San Saba, Mills, and Lampasas Counties............................. 7-4

7.3. Location of tested archaeological sites in the tri-county research area .......................................... 7-13

7.4. Select locations where previous research has been conducted on burned rock middens .................... 7-20 


\section{Tables}

5.1. Excavated Volume of 1-x-1-m Excavation Units and Column Sample at 41SS164 _......................... 5-5

5.2. Description of the Deposits Illustrated in Figure 5.5

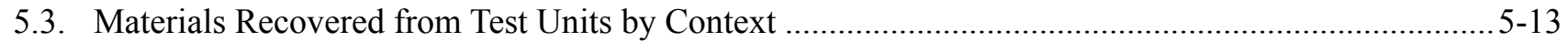

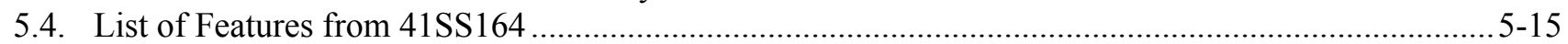

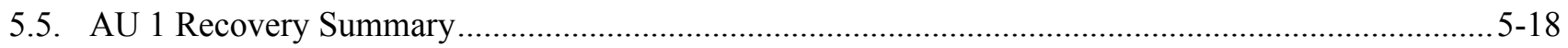

6.1. Material Recovered or Recorded from 41SS164 Testing ............................................................... 6-1

6.2. Artifact Recovery from 41SS164 by Excavation Unit and Column Sample...................................... 6-2

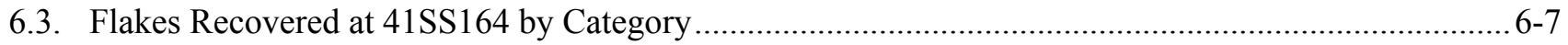

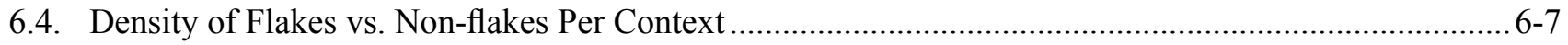

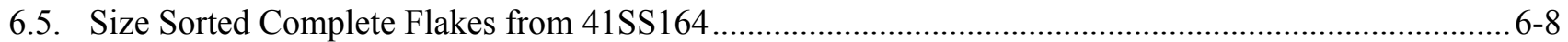

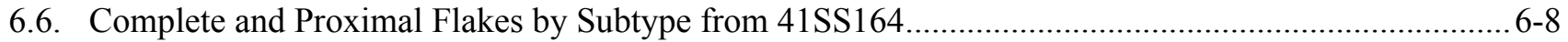

6.7. Ratio of Complete and Proximal Flakes by Recovered Context ..................................................... 6-9

6.8. Distribution of Complete Flakes by Size Class and General Elevation Range ................................... 6-10

7.1. Previously Recorded Sites in the Lampasas Cut Plains.................................................................. $7-6$

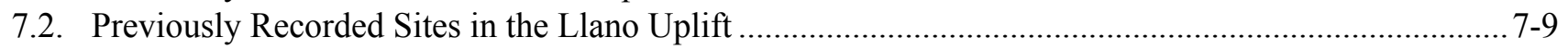

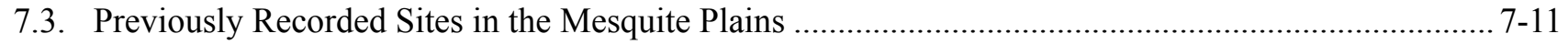

7.4. Summary of Tested Sites Selected for Study ................................................................................ 7-14

7.5. Numbers of Identified Projectile Point Types Recovered from the McCann Site .............................. 7-18

7.6. Numbers of Identified Chipped Stone Tools Recovered from the McCann Site................................ 7-19

8.1. Previously Recorded Sites with Temporal Information................................................................. 8-3

8.2. Matrix of Previously Recorded Sites in San Saba, Mills, and Lampasas Counties............................... 8-7

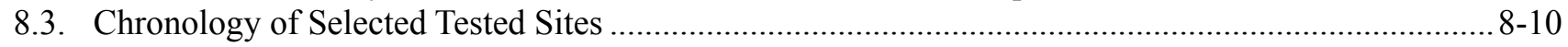

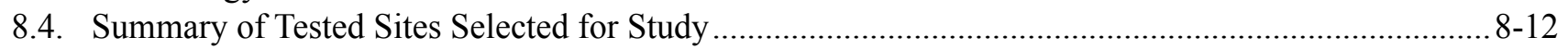

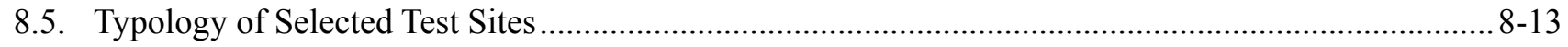




\section{MANAGEMENT SUMMARY}

Project Title: Significance Testing of Site 41SS164, San Saba County, Texas.

TxDOT CSJ Number: 0923-25-014.

SWCA Project Number: 12910-192-AUS.

Project Description: TxDOT proposes to remove the existing single span steel Pratt through truss bridge on CR 228 at Richland Springs Creek in central San Saba County, Texas, and replace it with a two-lane concrete slab bridge with girder spans. Some grading of the existing roadway adjacent to the bridge will be required. The new bridge and modified roadway will need additional ROW, which will be obtained from the northern side of the existing TxDOT ROW. Site 41SS164, a buried prehistoric campsite, is located within the area of potential effect for the project. As the site had not been assessed for its eligibility for inclusion to the NRHP or for listing as a SAL, significance testing was conducted.

Location: Site 41SS164 is located on the east side of Richland Springs Creek, northwest of the City of San Saba, central San Saba County, Texas. The site is located within public property controlled by TxDOT, as well as adjacent private land. On the publicly owned portion of the site, CR 228, a graded dirt road, and several layers of fill cover the site. A steel truss bridge has impacted the site at the edge of the terrace overlooking Richland Springs Creek. Although the site extends to the south of CR 228, the testing project was confined to the TxDOT ROW. The site appears on the Blucher Mountain, Texas USGS 7.5-minute topographic map.

Excavated Volume: $3.53 \mathrm{~m}^{3}$.

Principal Investigator: Kevin A. Miller.

Texas Antiquities Permit: 4156.

Dates of Work: June 6-13, 2006.

Purpose OF Work: As the construction project will involve federal funds from the Federal Highway Administration (FHWA) and involves state land controlled by the Brownwood District of TxDOT, investigations were conducted in compliance with the Texas Antiquities Code; the National Historic Preservation Act (NHPA); the Programmatic Agreement between the FHWA, the Advisory Council on Historic Preservation (ACHP), TxDOT, and the Texas Historical Commission (THC); and the Memorandum of Understanding between TxDOT and the THC.

Number of Sites: One, 41SS164.

ELIGIBILITY OF Sites: The portion of 41SS164 within the road ROW is not eligible for NRHP listing under 36 CFR 60.4 and does not warrant SAL designation under 13 TAC 26.8.

Recommendations: Data recovery investigations are not recommended.

Curation: The artifacts and records from the project will be curated at the Texas Archeological Research Laboratory (TARL). 



\title{
Chapter 1
}

\section{INTRODUCTION}

\author{
Mindy L. Bonine
}

\section{INTRODUCTION}

Site 41SS164, a small prehistoric campsite, occupies a portion of a terrace overlooking Richland Springs Creek, a tributary of the San Saba River in San Saba County, Texas (Figure 1.1). Richland Springs Creek flows roughly from west to east, weaving its way around the hilly topography of the area to the San Saba River about 4 miles west of the city of San Saba, Texas. Terraces parallel Richland Springs Creek along its windy path, and separate the floodplain of the creek from the rocky uplands of hilltops and hillslopes. It is upon one of these terraces on the eastern bank that $41 \mathrm{SS} 164$ sits. The site is approximately $7.4 \mathrm{~km}(4.6$ miles) northwest of the confluence of Richland Springs Creek and the San Saba River.

Northwest of San Saba, between U.S. Highway (US) 190 and State Highway (SH) 16, a network of county roads connects the rural farms and ranches with larger roadways. One of these roads, County Road (CR) 228, is an "L" shaped road connecting CR 226 with $\mathrm{CR}$ 224 (Figure 1.2). Many of these county roads are not paved, but consist of densely compressed gravel beds just wide enough for two vehicles to pass each other. CR 228 crosses both Richland Springs Creek and Elm Branch; at Richland Springs Creek a steel one-lane Pratt through truss bridge spans the banks. Just east of the bridge, site $41 \mathrm{SS} 164$ lies on the terrace occupied by the edge of the bridge, the roadway of CR 228, and farm and ranch land beyond (Figure 1.3). The bridge crossing the creek banks is located 0.37 miles east of the bend in CR 228. The vegetation surrounding the area includes short clump grasses, with large oak and pecan trees near the creek bank.

The site was initially located during an archaeological survey prompted by the planned replacement of the bridge at Richland Springs Creek (Clark and Owens 2006). At the time of the survey, only the areas along the narrow shoulder and portions of the adjacent private property to the south were investigated with subsurface excavations. Subsequently, the Texas Department of Transportation (TxDOT) determined that additional investigations were necessary to determine if the site retained sufficient integrity and information potential to be eligible under Criterion D of the National Register of Historic Places (NRHP) or for listing as a State Archeological Landmark (SAL). As such, SWCA Environmental Consultants (SWCA) was contracted by the Environmental Affairs Division (ENV) of TxDOT to conduct significance testing at site 41SS164.

At the time of the archaeological survey, prehistoric cultural material was observed on the ground surface, in a shovel test, and within a backhoe trench in the area southwest of the bridge over Richland Springs Creek. The construction of the bridge, a fence, and the roadway had impacted the surface of the site, but no other disturbances were observed. As the possibility of more intact prehistoric cultural material under the current road base was evident in the backhoe trench, the current research focused on investigating portions of site $41 \mathrm{SS} 164$ within the current right-of-way (ROW) that would be further impacted by the proposed undertaking. Additional backhoe trenches and test excavation units were utilized to determine the depth of deposits and the overall site limits, where possible. Although the site extends outside of the current ROW of CR 228, the significance testing investigations were limited to the portion of the site within the CR 228 ROW.

SWCA performed the investigations under General Services Contract \# 575XXSA007, Work Authorization \# 57521 SA007. The Texas Historical Commission (THC) issued Texas Antiquities Permit 4156 to Principal Investigator Kevin A. Miller. Project Archaeologist Mindy L. Bonine supervised the daily fieldwork, which took place June 6-13, 2006. Co-Principal Investigator Brett A. Houk assisted with the initial fieldwork setup and interpretation. The completion of this final report was conducted under General Services Con- 


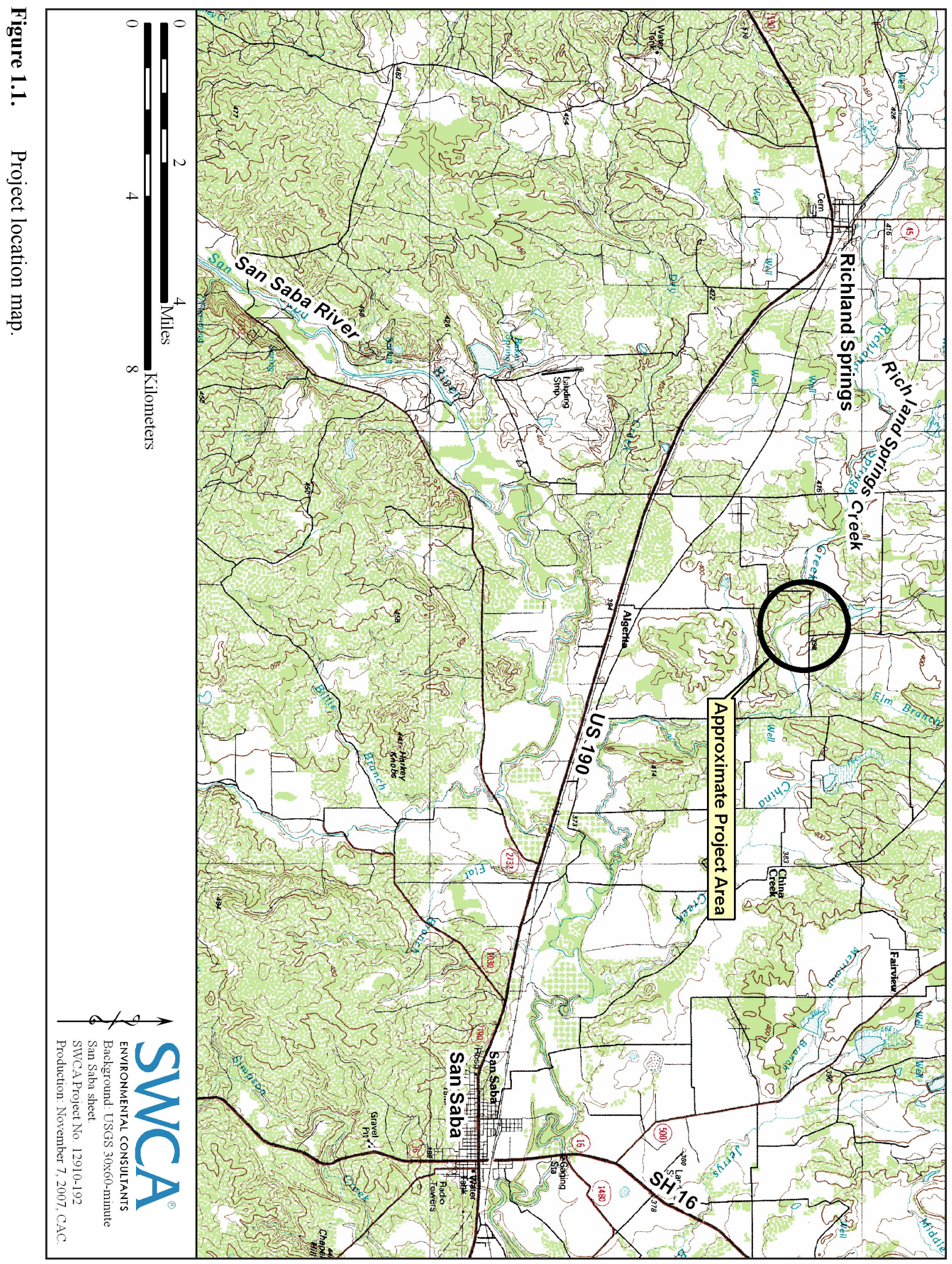




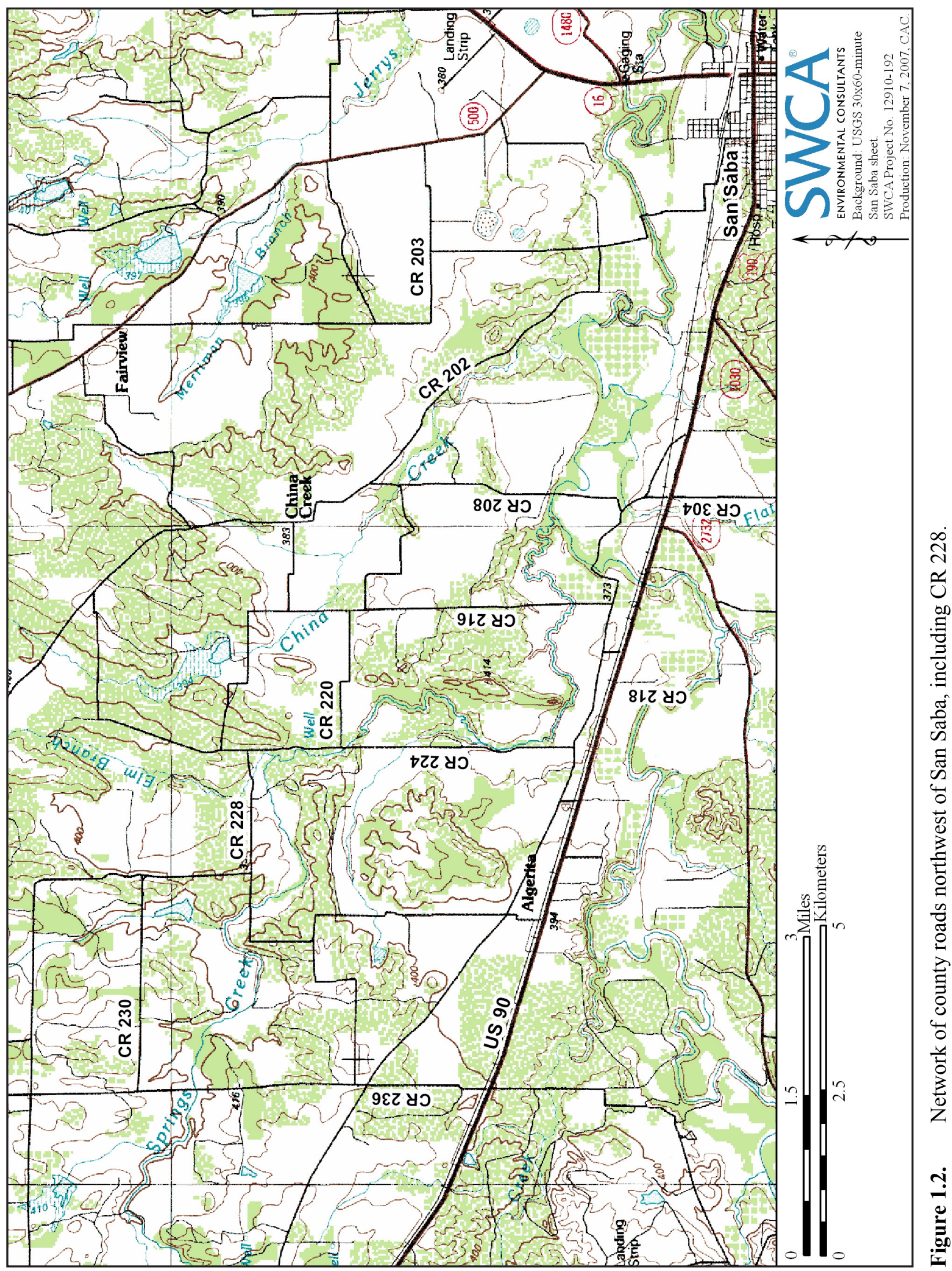




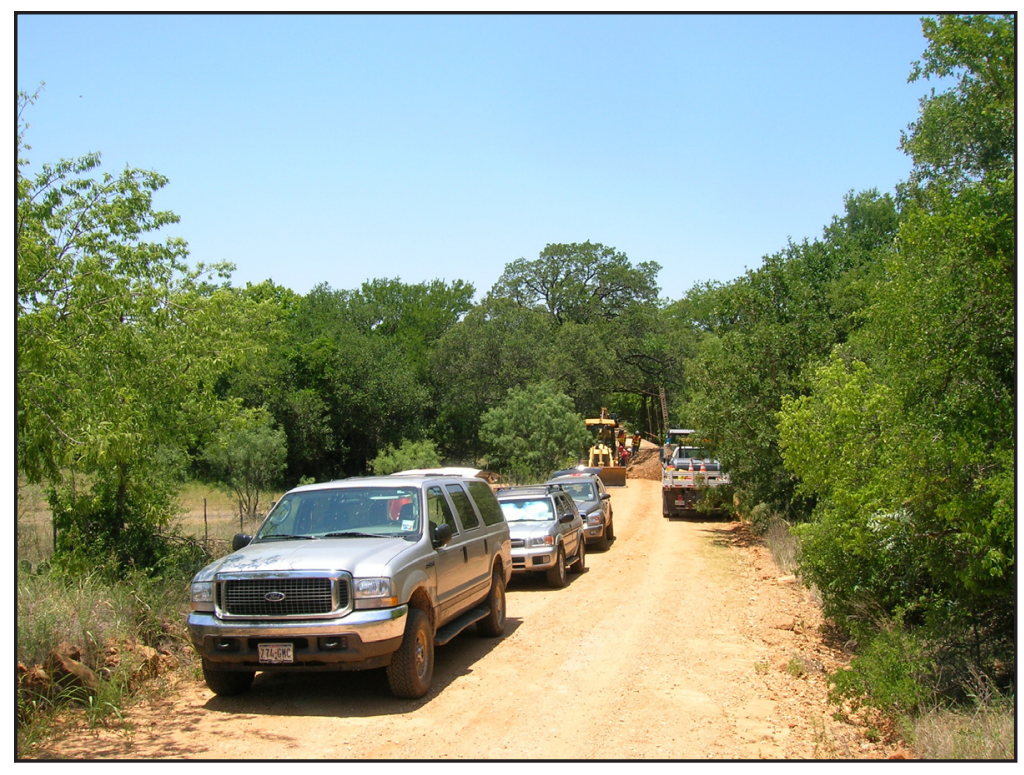

Figure 1.3. Photograph of 41SS164, facing west. Site area is located between the parked vehicles and the bridge.

tract \# 577XXSA002, Work Authorization \# 577 05 SA002.

\section{Description of Proposed UNDERTAKING FOR CR 228}

Currently, CR 228 is an unimproved gravel road with an aging single span steel Pratt through truss bridge crossing Richland Springs Creek (Figure 1.4). Because of the need to replace the bridge and provide two-lane access across the creek, the Brownwood District of TxDOT proposes to construct a concrete slab bridge with three girder spans. The project would require some new ROW at the location of the bridge crossing in order to widen the roadway as it approaches the bridge. Site 41SS164 is located within the Area of Potential Effects (APE) of direct and indirect impacts related to construction of the bridge.
The existing steel truss bridge is 76.5 feet long and 15.58 feet wide. The current fence line indicates the extent of the current ROW. The new bridge structure would be 125.25 feet long and 25 feet wide. Four vertical concrete walls 41.75 feet apart will support pre-stressed concrete I-beams, which in turn will support the concrete deck of the bridge. Additional ROW, which will be needed to widen the bridge, will be taken from the northern side. The eastern end of the bridge, including one of the vertical concrete support walls and a 50-foot wide soil retention wall, will impact the western end of the site (Figure 1.5). This is the only area that will be significantly impacted, however. The central and eastern ends of the site will not be impacted to the same degree, as several layers of roadway fill have covered the site, and deep trenching is not expected at this end of the bridge construction. Indirect impacts associated with transporting construction material and building the new bridge would take place within the current ROW and may impact the site.

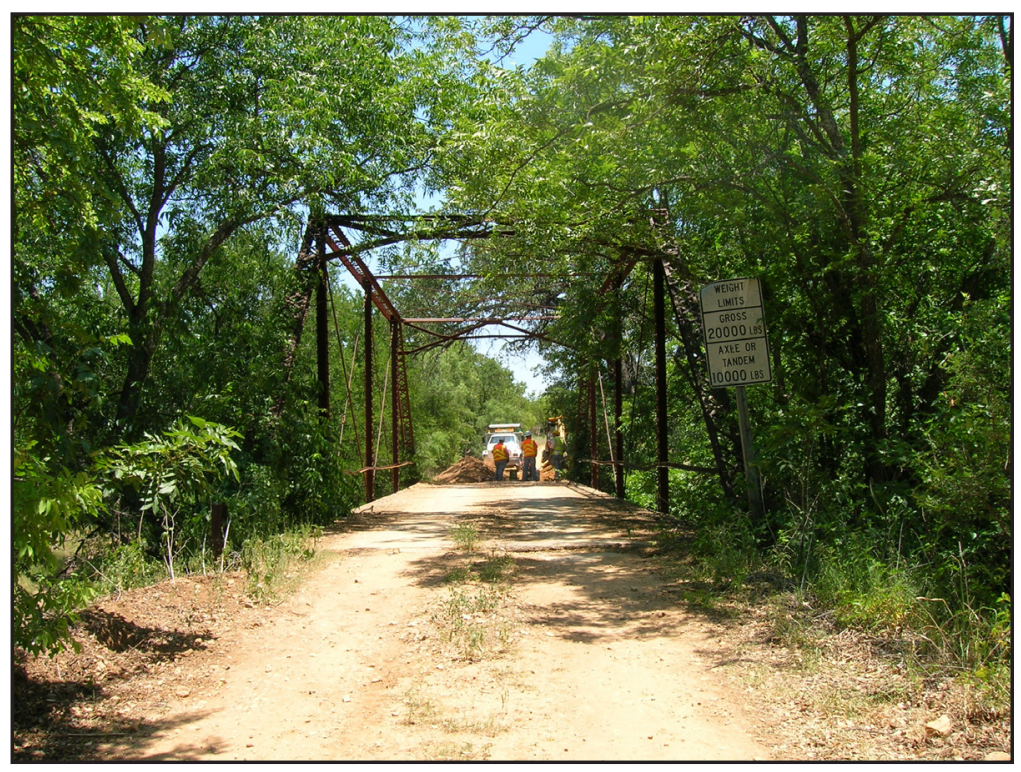

Figure 1.4. Existing bridge over Richland Springs Creek along CR 228. 


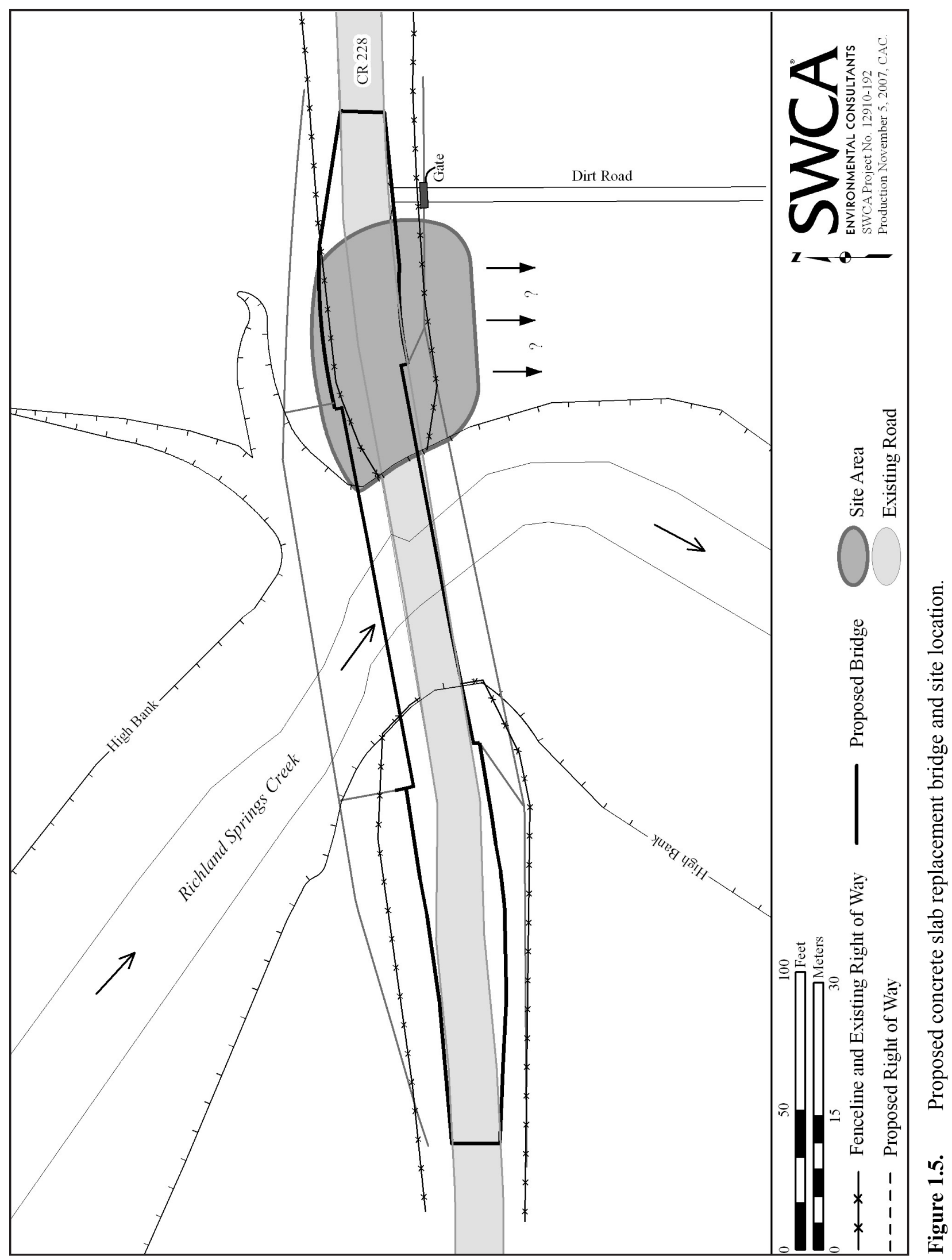




\section{Background on the Previous Archaeological Investigations}

In May 2006, Horizon Environmental Services, Inc. (Horizon) conducted a cultural resources survey of the intersection of CR 228 and Richland Springs Creek, a tributary of the San Saba River, San Saba County (Clark and Owens 2006). The survey stemmed from the need for TxDOT to replace the existing bridge over the creek. During those investigations, site 41SS164 was discovered on the east bank of Richland Springs Creek and on the south side of CR 228.

The Horizon intensive pedestrian survey included surface inspection, shovel testing, and backhoe trenching (Clark and Owens 2006). The investigation began with four shovel tests placed within each on the four quadrants surrounding the existing bridgenortheast, southeast, northwest, and southwest. In addition, three backhoe trenches were excavated in three of the four quadrants of the bridge, all but the northeast quadrant (Clark and Owens 2006).

Cultural material was initially noted on the ground surface in the ROW between the gravel road and a private property fence line in the southeastern quadrant of the crossing. In addition, a positive shovel test was excavated in that area. Subsequently, the landowner gave permission to place a backhoe trench on the opposite side of the fence just south of the original shovel test. The 4-m long backhoe trench placed there encountered an upper level of approximately $1.9 \mathrm{~m}$ of brown to strong brown silty clay loam (Clark and Owens 2006). Cultural material (consisting of burned sandstone, a biface fragment, and chert debitage) was concentrated between 30 and $70 \mathrm{~cm}$ below the surface (cmbs). The remainder of this stratum consisted of strong brown silty clay loam with only one piece of burned sandstone evident in the trench profile. A 1.5-m thick level of strong brown very silty loam was located under the stratum with cultural material (Clark and Owens 2006).

As a result of the investigation by Horizon, site 41SS164 was defined as a prehistoric campsite consisting of a surface scatter and subsurface remains including lithic debitage, bifacial tools, and fire- cracked sandstone (Texas Archeological Research Laboratory [TARL], 41SS164 site form). It was also reported that the landowner found a Fairlandlike projectile point on the morning of the Horizon investigations. It was found approximately $10 \mathrm{~m}$ east of their backhoe trench on the modern ground surface in the southern quadrant (Clark and Owens 2006).

\section{Report Organization}

This report presents the results of SWCA's testing investigations at site 41SS164. Chapter 2 provides an overview of the natural setting of the project area, and Chapter 3 presents a summary of the cultural setting, including discussions on previous archaeological investigations and a regional cultural history. The research design and methods used to conduct the fieldwork and analysis are described in Chapter 4. The results of the investigations, including a narration of the excavation as they progressed, descriptions of cultural material, and a general summary of the site, are presented in Chapter 5. An analysis and detailed description of the recovered materials is described in Chapter 6. Chapter 7 presents the data set used to conduct a comparative analysis and place site 41SS164 in a wider prehistoric context, and Chapter 8 presents the results of the comparative analysis and a general discussion of the study. Chapter 9 summarizes the content of the report and makes recommendations on the significance of site 41SS164, and Chapter 10 consists of references cited. Supporting documentation in the form of appendices include tables of materials recovered, the results of the radiocarbon assays, the macrobotanical analysis, and a specimen inventory. 


\title{
Chapter 2
}

\section{EnVironmental Setting}

\author{
Mindy L. Bonine and Charles Frederick
}

\section{INTRODUCTION}

Site 41SS164 is located in central Texas within the Llano Uplift, near its northern boundary. It is only a few hundred meters from the border of the Llano Uplift and the Rolling Plains (Figure 2.1). The Llano Uplift is a distinct mound of granite and sandy soils that is surrounded on the east, south, and west by the Edwards Plateau. The Llano Uplift and Edwards Plateau together are generally known as the "Hill Country," and are bounded on the east and south by the Balcones Fault (the surface expression of this fault is the Balcones Escarpment, which separates the Hill Country from the Texas Coastal Plain), on the north by the Rolling Plains, and on the west by the Trans Pecos and a small portion of the High Plains (Natural Heritage Policy Research Project [NHPRP] 1978).

The environmental and climatic conditions of this region have fluctuated considerably over the past 12,000 years, and the current conditions were not always prevalent in and around site 41SS164. Thus, the discussion below provides an overview of the presentday environmental setting, for which we have the most information. Geomorphological investigations were conducted during the significance testing fieldwork, providing regional and local geomorphology. The present environmental setting is followed by a brief history of the regional paleoenvironmental record as it is currently understood. This discussion is based on the results of field investigations preformed by SWCA archaeologists and a review of relevant literature.

\section{GeologY}

Site 41SS164 is approximately 4.6 miles northwest of the confluence of Richland Springs Creek and the San Saba River. Geologically, Richland Springs Creek at this point is located at the center of a very thin line of alluvium, consisting of floodplain deposits or low ter- race deposits made up of gravel, silt, clay, and organic matter to a depth of 35 feet (Keir et al. 1995) (Figure 2.2). Immediately adjacent to the alluvial deposits around the site area is the sandstone, shale, mudstone, conglomerate, siltstone, and limestone of the Strawn Group, undivided (Keir et al. 1995). As can be seen in the stratigraphy of the immediate site area, 41SS164 is situated both in the alluvium from Richland Springs Creek and the transition area to the Strawn Group (see Chapter 5).

\section{OVERVIEW OF GEOMORPHOLOGY}

Site 41SS164 is in an area mapped by the Bureau of Economic Geology as underlain by the Upper Pennsylvanian-age Strawn Group (Kier et al. 1995). The Strawn Group consists of alternating beds of sandstones, shale, and occasional limestones that were deposited in a shallow-water sea. The terrigenous component of these deposits was derived from erosion of a landmass that was located to the east or northeast that is now concealed beneath later Cretaceous deposits (Sellards et al. 1932:109). In the immediate vicinity of the site, Kier et al. (1995) have mapped the ridge forming the southern valley wall as Sandstone 15, and the northern valley wall as Strawn Group, undivided. The sandstones mapped by Kier et al. (1995) were mapped on the basis of their geomorphic expression observed on aerial photographs, and are not necessarily entirely sandstone, but may contain significant amounts of shale as well.

It is notable that the Kier et al. (1995) map does not reflect the plethora of ancient (Quaternary) fluvial geomorphic features and deposits that are present in the immediate landscape that are associated with the activity of Richland Springs Creek and the San Saba River during the Pleistocene. Chert-rich ancient fluvial gravels cap many of the low bedrock hills and ridges in this area, and Pleistocene terrace deposits and/or 


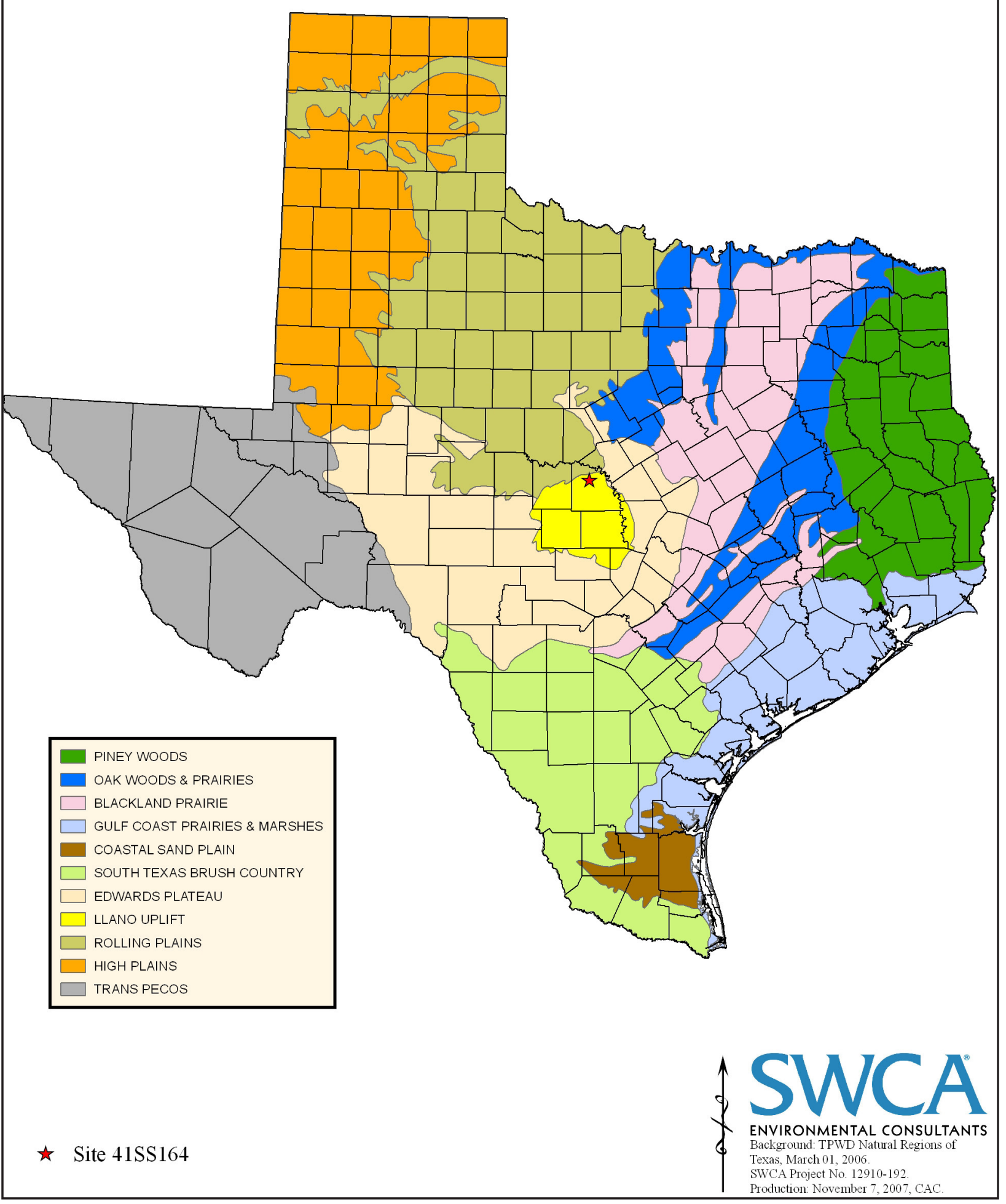

Figure 2.1. Natural Regions of Texas, with the location of site 41SS164. 


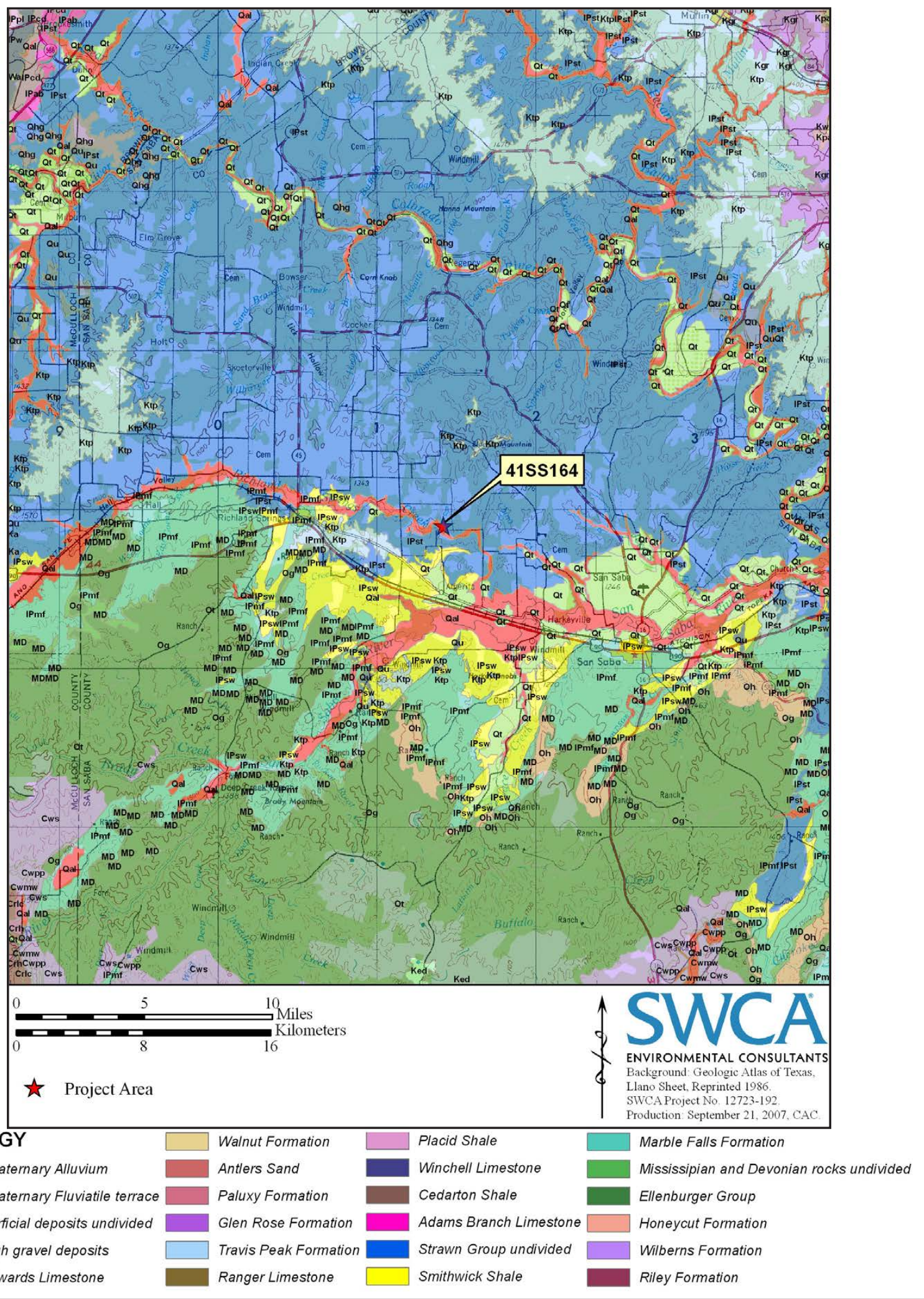

Figure 2.2. Geology of San Saba County and the San Saba River Valley. 
erosional surfaces dominate much of the landscape south of this segment of the Richland Springs Creek valley. For instance, today, Richland Springs Creek flows within a bedrock confined valley that ranges from as little as $200-700 \mathrm{~m}$ or more wide, and lies around $30-40 \mathrm{~m}$ below the adjacent upland knolls. Immediately to the south of the ridge that forms the southern boundary of Richland Springs Creek now lies a prominent arcuate bedrock cut valley. Although it may have at one time been occupied by the San Saba River, this feature is much more consistent with the modern Richland Springs Creek valley, and the floor of this paleo-valley lies about 20-40 feet above the present day Richland Springs Creek valley. This feature is now occupied by a low order, unnamed drainage, which flows into Richland Springs Creek a couple of miles downstream of the site. The upstream end of this arcuate valley is a very large terrace surface, which has its southern border at the modern San Saba River channel.

That the Geologic Atlas of Texas map significantly under-represents the Quaternary deposits in this region is not unusual, and this point may seem to be a mere geological detail. But the abundance of ancient terraces containing workable stone presents a wealth of lithic resource opportunities for prehistoric groups, in a landscape, which to the immediate north and west, is rather chert poor. To the south of the San Saba River there are several chert-bearing deposits (e.g., the Ordovician age Gorman and Tanyard Formations), and to the east lies the Colorado River and the Calahan Divide, which is capped by the Lower Cretaceous Edwards Group. The Strawn Group outcrop to the north and west, however, especially north of Richland Springs Creek, appears to contain little in the way of workable stone.

\section{LOCAL GEOMORPHOLOGY}

Site 41SS164 is situated within Quaternary alluvium at the eastern edge of the Richland Springs Creek valley (Figure 2.3). It is located on the left bank of the stream, at the confluence of a low order $\left(2^{\text {nd }}\right)$ tributary, $10 \mathrm{~m}$ north of the bridge, and just downstream of the point where Richland Springs Creek emerges from partial bedrock confinement. Immediately to the north of CR 228, the stream is incised at the extreme edge of the valley, between the Holocene valley deposits on the right bank and a bedrock upland on the left bank. Bedrock is exposed in the streambed a short distance $(\sim 50 \mathrm{~m})$ upstream from the site and is visible from the existing bridge.

At least four constructional alluvial surfaces are present in the Richland Springs Creek valley and are present in the immediate vicinity of the bridge: the modern floodplain $\left(\mathrm{T}_{0}\right)$, a first $\left(\mathrm{T}_{1}\right)$ and second terrace $\left(\mathrm{T}_{2}\right)$, and high terrace $\left(\mathrm{T}_{3}\right)$ which caps the surrounding hills (Figure 2.4). These investigations were restricted to the roadway and bounded by private property on either side. It is likely that a more comprehensive examination of this landscape would reveal additional alluvial landforms in this valley.

\section{The Modern Floodplain ( $\left.\mathbf{T}_{0}\right)$}

The modern floodplain is relatively narrow and comprises paired surfaces that lie about $2.5 \mathrm{~m}$ above the thalweg and are inset below the $\mathrm{T}_{1}$ and $\mathrm{T}_{2}$ surfaces. Narrow point bars are present on the insides of prominently arcuate meanders and form narrow gravelly ramps that rise up onto the $T_{0}$ surface. A narrow fragment of the floodplain lies beneath and immediately to the north of the bridge. In the immediate vicinity of the site, the $\mathrm{T}_{0}$ surface is about 25-35 m wide, when measured from the channel margin to the scarp where it abuts the $T_{1}$ or $T_{2}$ surface. Discussions with local residents revealed that a flood inundated the entire valley floor in 1938 and that overbank flooding has occurred at least once since the early 1980 s.

\section{The First Terrace $\left(T_{1}\right)$}

At least half of the valley floor is represented by the $\mathrm{T}_{1}$ surface. This terrace rises about $4 \mathrm{~m}$ above the thalweg and has a generally flat tread, but there is a prominent levee-like rise present where this surface abuts the active stream channel. This surface is prominently visible on the aerial photograph of this area, especially south of the county road, where it exhibits a clearly darker tone than the adjacent $T_{2}$ surface. 

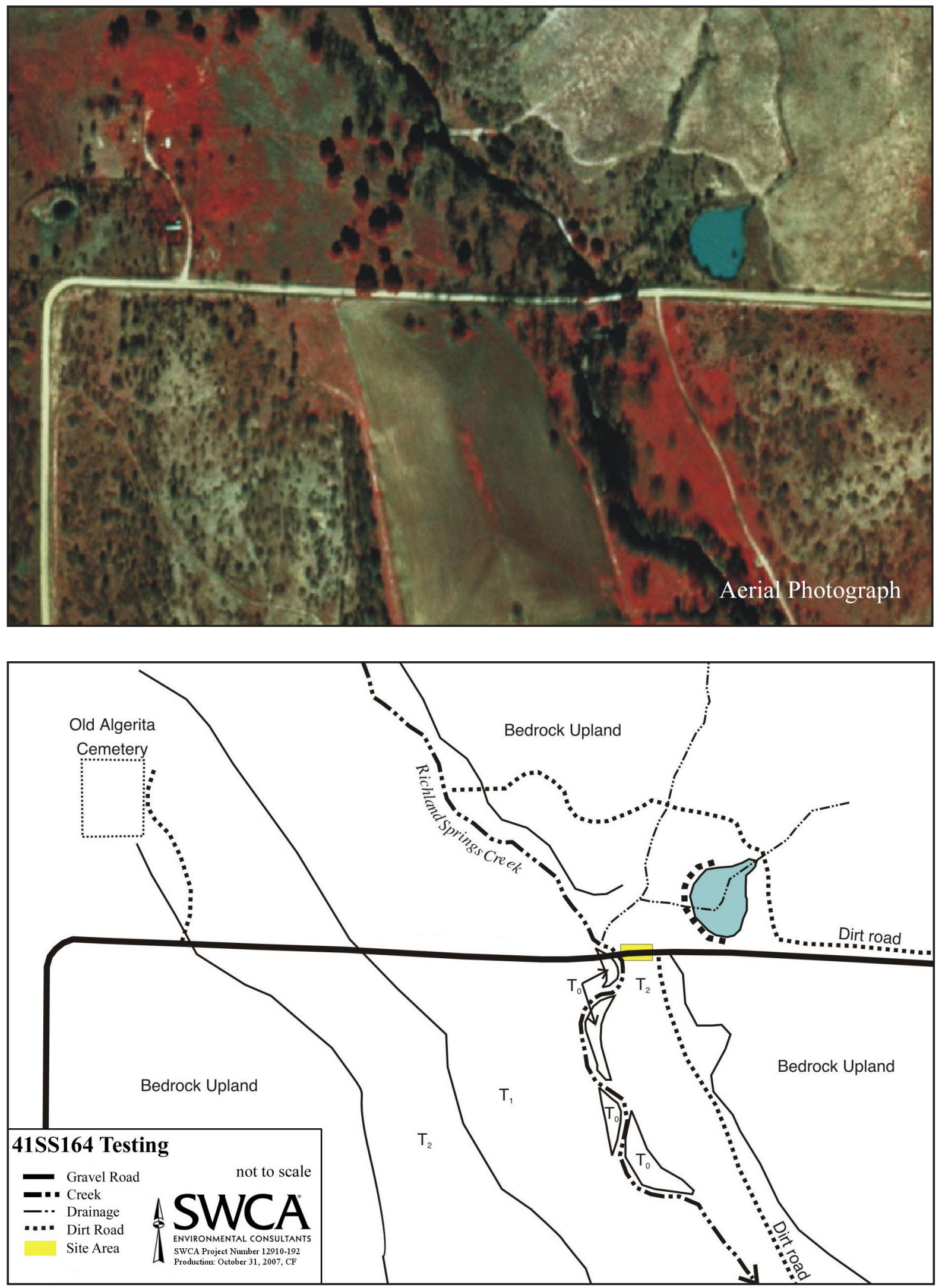

Figure 2.3. Local geomorphology of the area around Richland Springs Creek. 


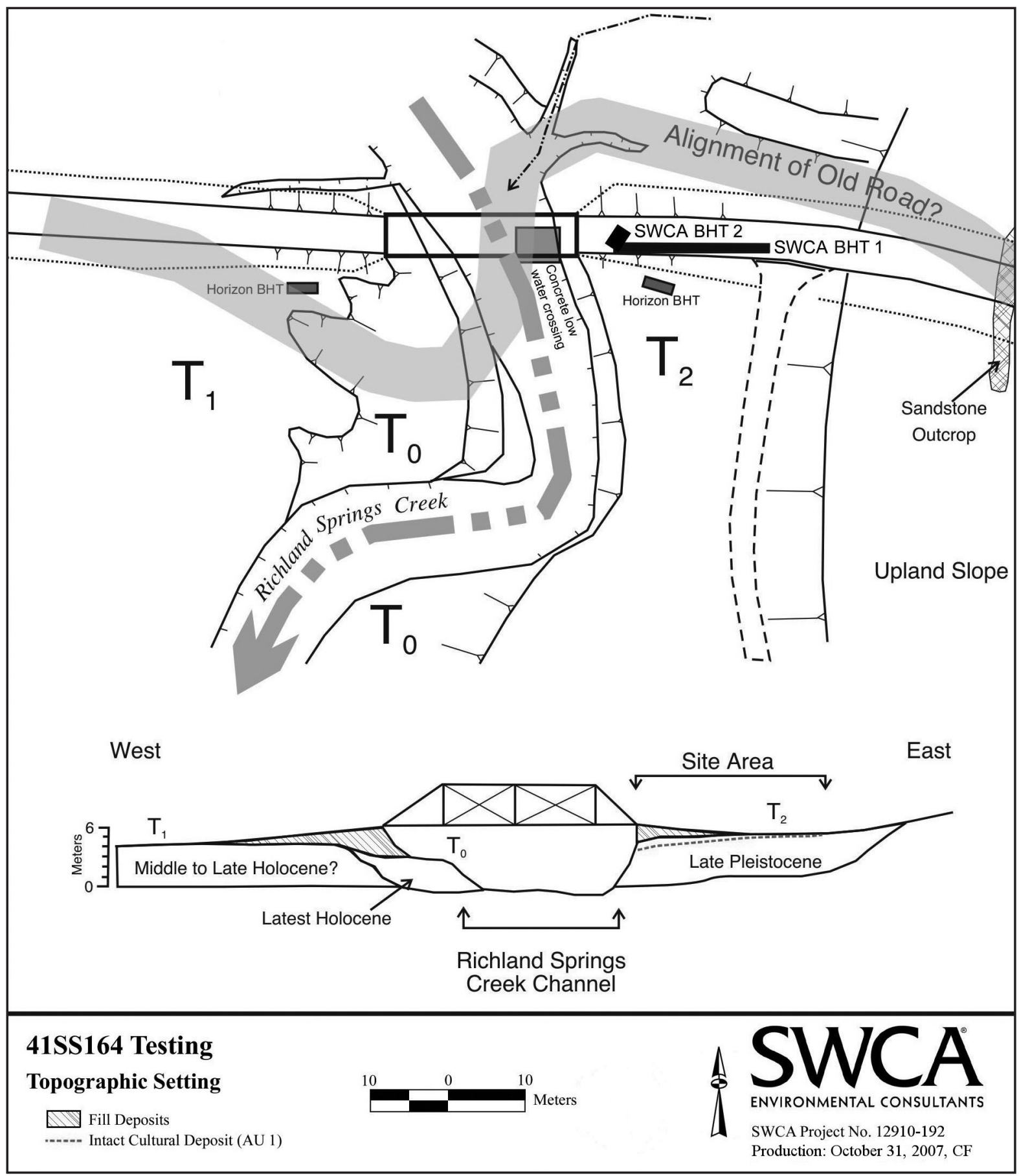

Figure 2.4. Location of terraces around Richland Springs Creek. 


\section{The Second Terrace $\left(\mathrm{T}_{2}\right)$}

The site is situated upon and beneath the $\mathrm{T}_{2}$ surface, and this terrace lies at the rear of the Late Quaternary alluvial valley. It is slightly higher than the $T_{1}$ surface. At the bridge, the $\mathrm{T}_{2}$ surface lies about $5 \mathrm{~m}$ above the thalweg, and another fragment is clearly visibly from CR 228, along the western valley margin in the vicinity of the Old Algerita Cemetery to the west of site 41SS164. The differences in height between the $T_{1}$ and $T_{2}$ surfaces can be easily seen at the bridge, which is graded to the $\mathrm{T}_{2}$ surface on the east and the $T_{1}$ surface on the west (Figure 2.4).

\section{The Third or High Terrace $\left(\mathbf{T}_{3}\right)$}

The highest constructional surface recognized during this phase of work is the $T_{3}$ surface, which comprises the flat to moderately dissected ridge crests forming the drainage divide between Richland Springs Creek and the San Saba River. A widespread body of alluvial gravels, which are probably ancestral San Saba River deposits, underlies this surface. Although CR 228 crosses this surface in at least one place west of the bridge, across a small knoll about $460 \mathrm{~m}$ south of the Old Algerita Cemetery, the best exposure of the gravels which underlie it are found in the road cut across a hill on CR 226, southeast of the intersection of CR 226 and CR 228. In this location the road cut exposes a Stage V calcic horizon formed in alluvial gravel. The calcic horizon appears to have experienced karstic etching, with small solution pits separating pinnacle-like parts of the K horizon, which exhibit both laminar and massive carbonate morphology.

\section{SoILS}

The soils for the site consist of Frio silty clay loam, occasionally flooded, with Nocken-Callahan-Throck association, hilly just to the east. The Frio silty clay loam soils are deep, nearly level to gently sloping soils on floodplains of the San Saba River and its tributaries. Slopes are generally less than 1 percent. The soils are moderately alkaline, well drained, with slow permeability, flooding about once every 5-12 years. Frio silty clay loam soils are present along both sides of Richland Springs Creek around the area of site 41SS164. Just to the east at higher elevations, Nocken-Callahan-Throck association soils are moderately deep, loamy and clayey soils on uplands, dissected by drainageways. They are located on hill summits, side slopes, and along escarpments of low hills. Sandstone boulders, stones, and cobbles cover about 60 percent of the ground surface. The soils are mildly alkaline and well drained, with moderately slow permeability and rapid runoff.

The soils and geology as well as aerial and topographic maps indicate that the site sits on a large alluvial $\mathrm{T}_{2}$ terrace of a creek segment that effectively divides two areas: one that consists of limestone bedrock (to the south), and another that contains sandstone and shale bedrock (to the north). The area lies on the outwash plains above the bottom lands of the San Saba River valley, which begins downstream near the confluence of Richland Springs Creek and the San Saba River (Figure 2.5). Around site 41SS164's location, Richland Springs Creek occupies the northern end of the outwash plains, very near the Nocken-Callahan-Throck association soils over sandstone and shale bedrock, as indicated by these upland soils appearing just east of the site. A pocket of Nocken-Callahan-Throck association soils within the outwash plains also emerges to the south of Richland Springs Creek near the site location.

\section{Vegetation}

As mentioned above, site 41SS164 is located at the northern edge of the Llano Uplift. The Llano Uplift is the central mineral region of Texas exhibiting a rolling to hilly topography with granite exfoliation domes and sandy soils. Mesquite and whitebrush dominate the area, but pockets of oak and oakhickory woodlands are found in sandy, well watered soils (NHPRP 1978:22). This area is included with the Edwards Plateau in the Balconian biotic province, just south of the Texan biotic province (Blair 1950). However, maps of the Level III Ecoregions of Texas, based on an analysis of geology, physiography, vegetation, climate, soils, land use, wildlife, and hydrology, indicate that the area where site 41SS164 sits is not within the Edwards Plateau region, but the Central Oklahoma/Texas plains (Omernik 1987). 
2-8 Chapter 2




In addition, another ecoregion map places the area within the Cross Timbers and Prairies (Gould et al. 1960). Taken together, these data shows the transitional nature of the area where site 41SS164 is located and its easy incorporation into more than one ecologically defined area. For the purposes of this report, the vegetation descriptions will be based on the Edwards Plateau and the Cross Timers and Prairies ecoregions, and the faunal descriptions will be based on the Balconian and Texan biotic provinces.

Typical canopy cover for the Edwards Plateau region consists of live oak (Quercus virginiana), blackjack oak (Quercus marilandica), Lacey oak (Quercus glaucoides), plateau live oak (Quercus fusiformis), Mexican cedar (Juniperus mexicana), mesquite (Prosopis glandulosa), and some bald cypress (Taxodium distichum). Characteristic vegetation of the Cross Timbers and Prairies include an overstory of post oak (Quercus stellata), blackjack oak (Quercus marilandica), Texas Buckeye (Aesculus glabra), Texas Ashe (Fraxinus texensis) Mexican plum (Prunus mexicana), cedar elm (Ulmus crassifolia), pecan (Carya illinoensis), and some mesquite (Prosopis sp.) (Blair 1950; Simpson 1988; Spearing 1991). Texas oak (Quercus texana), common in the Edwards Plateau, and ashe juniper (Juniperus ashei), common in both areas, are generally absent in the Llano Uplift (Griffith et al. 2004).

Grasses that are typical of the Edwards Plateau region include switchgrass (Panicum virgatum), Indian grass (Sorghastrum nutans), beardgrass (Bothriochloa spp.), sideoats grama (Bouteloua curtipendula), King Ranch bluestem (Bothriochloa ischaemum), little bluestem (Schizachyrium scoparium), sideoats grama (Bouteloua curtipendula), Canada wildrye (Elymus canadensis), curly mesquite (Hilaria belangeri) and buffalograss (Buchloe dactyloides). Other plants commonly found within this vegetational area include agarita (Berberis trifoliolata), ashe juniper (Juniperus ashei), Texas persimmon (Diospyros texana), elbowbush (Forestiera pubescens), Texas mountain laurel (Sophora secundiflora), Spanish moss (Tillandsia usneoides), prickly-pear cactus (Opuntia spp.), claret cup cactus (Echinocereus triglochidatus), and pencil cactus (O. leptocaulis). The Cross Timbers and Prairies includes an understory of bunch grasses (e.g., big bluestem,
Indian grass, Canada wild-rye, hairy grama, and Texas wintergrass), various shrubs, hairy tridens ( $E r$ ioneuron pilosum), laurel greenbriar (Smilax laurifolia), American beautyberry (Callicarpa americana), saw greenbriar (Smilax bona-nox) (Correll and Johnston 1979; Cox and Leslie 1999; Gould 2002; Hatch et al. 1990; Kutac and Caran 1994; Niehaus et al. 1984; Niering and Olmstead 1990; Petrides 1979; Petrides and Petrides 1992; Schmidly 1983; Simpson 1988; Stein et al. 2003; Vines 1997).

\section{Fauna}

The Balconian and Texan biotic provinces are transitional zones extending from the mesic forests of eastern North America to the xeric grasslands of the central United States, which provide a varied habitat that contains a high faunal diversity. At least 49 species of mammal, 57 species of reptiles, and 23 species of amphibians have been identified as native to the Texan biotic province (Blair 1950). For the Balconian biotic province, Blair (1950) identifies 57 species of mammal, over 42 species of reptile, and 15 species of amphibians. None of the fauna for the Balconian is restricted solely to this province (Blair 1950).

Some mammals common to the Balconian province include: oppossum (Didelphis virginiana), eastern pipistrel (Pipistrellus subflavus), eastern fox squirrel (Sciurus niger), eastern cottontail rabbit (Sylvilagus floridanus), pocket gopher (Geomys breviceps), pallid bat (Antrozous pallidus), valley pocket gopher (Thomomys bottae), and badger (Taxidus taxus) (Burt and Grossenheider 1976).

Some native mammals common to the Texan biotic province include: oppossum (Didelphis virginiana), eastern mole (Scalopus aquaticus), eastern fox squirrel (Sciurus niger), pocket gopher (Geomys breviceps), fulvous harvest mouse (Reithrodontomys fulvescens), white-footed mouse (Peromyscus leucopus), hispid cotton rat (Sigmodon hispidus), eastern cottontail rabbit (Sylvilagus floridanus), and swamp rabbit (Sylvilagus aquaticus) (Burt and Grossenheider 1976). 
Mammals common to both of these provinces include coyote (Canis latrans), gray fox (Urocyon cinereoargenteus), mink (Mustela vison), muskrat (Ondata zibethica), raccoon (Procyon lotor), striped skunk (Mephitis mephitis), and white-tailed deer (Odocoileus virginianus). Historically, red wolf, gray wolf, bison, jaguar, pronghorn, and black bear ranged into or near these regions (Burt and Grossenheider 1976; Schmidly 1983).

The general reptilian assemblage for both provinces include the Great Plains rat snake (Elaphe guttata emoryi), Eastern yellowbelly racer (Coluber constrictor flaviventris), Yellow mud turtle (Kinosternon flavescan flavescan), bullfrog (Rana catesbiana), southern leopard frog (Rana utricularia), and the gulf coast toad (Bufo vallicepus) (Blair 1950; Conant and Collins 1998; Kutac and Caran 1994).

\section{Paleoenvironment}

Over the past 15,000 years, the environmental and climatic conditions in central Texas have varied considerably. Although researchers rely on pollen and phytolith studies to reconstruct the paleoenvironment, there are often contradictions between these two sources, as well as the data from different regions and time periods. Combined, most of the data can only indicate a general overview of the paleoenvironmental conditions. Hopefully, as the practice of collecting samples of pollen and phytoliths for paleoenvironmental conditions continues, a more concise and accurate reconstruction can be generated for each archaeological region in the state. Currently, the pollen studies in central Texas indicate a cool grassland environment was present roughly between 17,000 B.P. and 15,500 B.P. with a trend towards a warmer or more arid climate after 15,000 B.P. (Bousman 1992, 1994, 1998; Camper 1991; Nickels and Mauldin 2001).

After 10,000 B.P., changes in paleoclimatic conditions led to mass extinctions of megafauna across the region (Graham 1987; Graham and Lundelius 1984). Various pollen studies suggest a gradual and consistent warming and drying trend coupled with more seasonal climatic conditions throughout the Early to Middle Holocene (Bousman 1994, 1998;
Nickels and Mauldin 2001). Woodland environments were in decline throughout most of the Early to Middle Holocene and stopped around 6,000-5,000 B.P. Arboreal pollen then continued to decline after 5,000 B.P. and slightly increased during a period of a wetter climate (Bousman 1994). This arid interval is also presented by Nordt et al. (1994) from the Applwhite project from 6,000-4,800 B.P. However, Johnson and Goode's (1994) reconstruction of paleoenvironmental conditions do not correlate with Bousman's (1998) pollen based reconstruction dating from $8,000-6,000$ B.P. and report the arid interval between 5,000-2,500 B.P. Toomey and Stafford's (1994) revised interpretation of Hall's Cave in Kerr County indicates the arid episode occurred between 7,000-2,500 в.P. The phytolith analysis at WilsonLeonard indicates a general expansion of grasslands throughout most of the Holocene beginning around 9,500-4,000 B.P. (Fredlund 1998).

In the Late Holocene, Nordt et al. (1994) indicates a warm and dry period from 3,000-1,500 B.P. and Toomey and Stafford (1994) indicate a wet period around 2,500 B.P. at Hall's Cave. Other studies from the Gulf Coast and Choke Canyon indicate a wetter climate around 3,000 B.P. and 2,450 B.P. respectively (Ricklis 1994; Robinson 1982). Bousman's (1994) grass pollen frequencies indicate drying episodes around 1,600-1,500 B.P. and 500-400 в.P. 


\title{
Chapter 3
}

\section{Cultural Setting}

\author{
Mindy L. Bonine and Michael R. Chavez
}

\section{INTRODUCTION}

San Saba County resides within the Central Texas archaeological region, which extends across the Edwards Plateau and includes portions of the Blackland Prairie and Post Oak Belt (Collins 2004; Prewitt 1981; Turner and Hester 2002). This archaeological region is arbitrarily defined by a combination of physiographic and biogeographic characteristics that are thought to have influenced prehistoric systems of subsistence and settlement. Archaeological investigations in this and other archaeological regions are frequently aimed at identifying broad-scale diachronic changes in the prehistoric record across large geographic zones. This is not to say that these archaeological regions define specific areas where prehistoric communities with common cultural traits are located, as many hunter-forager groups are transphysiographic by nature, but there are some indications of specific environmentally-based behaviors exhibited in these regions, the Central Texas archaeological region included (i.e., the large quantity of burned rock middens in the region).

\section{Previous Investigations}

Records at TARL indicate that a little over 160 archaeological sites have been recorded in San Saba County as of October 2007. The types of sites found in San Saba County are quite variable, but open campsites with burned rock middens dominate the assemblage, followed by lithic scatter and procurement sites, rockshelters, a "buffalo jump," and various historic sites. Not many prehistoric sites are attributable to specific dates of occupation, but at least four sites show some evidence of Paleoindian occupation, and a little less than 30 sites (about 17 percent) date to the Archaic Period. Only a few sites are confirmed Late Prehistoric in occupation. Very few sites in San Saba County have been investigated beyond the basic recording stage; the majority of these sites are profiled in Chapter 7 and used in a comparative analysis with site 41SS164.

\section{Prehistoric Cultural History}

The following prehistoric cultural history derives its information from several central Texas regional chronologies: Black (1989), Collins (2004), Johnson and Goode (1994), which build upon the seminal efforts of Suhm (1960) and Prewitt (1981, 1985). Furthermore, significant archaeological sites within the Central Texas archaeological region have contributed important information to understanding prehistory, including the Richard Beene site at Applewhite Reservoir (McGraw and Hindes 1987; Thoms et al. 1996; Thoms and Mandel 1992), the Cibolo Crossing site at Camp Bullis (Kibler and Scott 2000), the Panther Springs Creek site in Bexar County (Black and McGraw 1985), the Jonas Terrace site in Medina County (Johnson 1995), the Camp Pearl Wheat site in Kerr County (Collins et al. 1990), 41BX1 in Bexar County (Lukowski 1988), 41BX300 in Bexar County (Katz 1987), and several sites at Canyon Reservoir (Johnson et al. 1962).

The following prehistoric cultural sequence is divided into three periods: Paleoindian, Archaic, and Late Prehistoric. The Historic period follows the Late Prehistoric, announcing the arrival of Europeans to central Texas. The Archaic period is subdivided into four subperiods: Early, Middle, Late, and Transitional.

\section{Paleoindian Period}

Human occupation of the Central Texas archaeological region is thought to have begun approximately 11,000 years ago. This period correlates with the end of the late Pleistocene, the last ice age in North America. These early Texans are characterized by small but highly mobile bands of foragers who were specialized hunters 


\section{3-2 Chapter 3}

of Pleistocene megafauna. But Paleoindians probably used a much wider array of resources (Meltzer and Bever 1995:59), including small fauna and plant foods. Faunal remains from Kincaid Rockshelter and the Wilson-Leonard site (41WM235) support this view (Collins 1998; Collins et al. 1989). Longstanding ideas about Paleoindian technologies also are being challenged.

Surficial and deeply buried sites, rockshelter sites, and isolated artifacts represent Paleoindian occupations in the central Texas region. Although Paleoindian site types are not well documented within San Saba County, they can be generally classified according to broad site type categories extrapolated from nearby regions. Both open and protected (rockshelter) types are known. Usually these sites are near permanent sources of water such as tributary creeks or springs. Bison kill sites, open and protected campsites, and non-occupation lithic sites are known from the Paleoindian period in Texas. Intra-site features include hearths and isolated burials. The WilsonLeonard site (41WM235), 41BX52, and 41BX229 contain stratified Paleoindian deposits (Hester 1980). The lower component at the Wilson-Leonard site contained a Paleoindian burial (Collins et al. 1998). The Vera Daniels site (41TV1324), at the confluence of the Colorado River and Barton Creek, has deeply buried deposits which yielded a Plainview fragment and a possible Clovis preform during limited testing (Ricklis et al. 1991).

Collins (2004) divides the Paleoindian period into early and late subperiods. Two projectile point styles, Clovis and Folsom, are included in the early subperiod. Clovis chipped stone artifact assemblages, including the diagnostic fluted lanceolate Clovis point, were produced by bifacial, flake, and prismatic-blade techniques on high-quality and oftentimes exotic lithic materials (Collins 1990). Along with chipped stone artifacts, Clovis assemblages include engraved stones, bone and ivory points, stone bolas, and ochre (Collins 1995:381; Collins et al. 1992). Clovis points are found evenly distributed along the eastern edge of the Edwards Plateau, where the presence of springs and outcrops of chert-bearing limestone are common (Meltzer and Bever 1995:58). Sites within the area yielding Clovis points and Clovis-age materials include Kincaid Rockshelter (Collins et al. 1989), Pavo
Real (Henderson and Goode 1991), and San Macros Springs (Takac 1991). Probable Clovis polyhedral blade core and blade fragments were found at the Greenbelt site in San Antonio (Houk et al. 1997b). Analyses of Clovis artifacts and site types suggest that Clovis peoples were well-adapted, generalized hunter-gatherers with the technology to hunt larger game but did not solely rely on it.

In contrast, Folsom tool kits - consisting of fluted Folsom points, thin unfluted (Midland) points, large thin bifaces, and end scrapers - are more indicative of specialized hunting, particularly of bison (Collins 1995:382). Folsom points have been recovered from Kincaid Rockshelter (Collins et al. 1989) and Pavo Real (Henderson and Goode 1991).

Postdating Clovis and Folsom points in the archaeological record are a series of dart point styles (primarily unfluted lanceolate darts) for which the temporal, technological, or cultural significance is unclear. Often, the Plainview type name is assigned to these dart points, but Collins (1995:382) has noted that many of these points typed as Plainview do not parallel Plainview type-site points in thinness and flaking technology. Recent investigations at the Wilson-Leonard site (Bousman 1998) and a statistical analysis of a large sample of unfluted lanceolate points by Kerr and Dial (1998) have shed some light on this issue. At Wilson-Leonard, the Paleoindian projectile point sequence includes an expanding-stem dart point termed Wilson, which dates to ca. 10,000-9,500 в.P. Postdating the Wilson component is a series of unfluted lanceolate points referred to as Golondrina-Barber, St. Mary's Hall, and Angostura, but their chronological sequence is poorly understood. Nonetheless, it has become clear that the artifact and feature assemblages of the later Paleoindian subperiod appear to be Archaic-like in nature and in many ways may represent a transition between the early Paleoindian and succeeding Archaic periods (Collins 1995:382).

\section{Archaic Period}

The Archaic period for the Central Texas archaeological region dates from ca. 8,800 to $1,300-1,200$ B.P. (Collins 2004) and generally is believed to repre- 
sent a shift toward hunting and gathering of a wider array of animal and plant resources and a decrease in group mobility (Willey and Phillips 1958:107-108). In the eastern and southwestern United States and on the Great Plains, development of horticultural-based, semi-sedentary to sedentary societies succeeded the Archaic period. In these areas, the Archaic truly represents a developmental stage of adaptation as Willey and Phillips (1958) define it. For central Texas, this notion of the Archaic is somewhat problematic. An increasing amount of evidence suggests that Archaic-like adaptations were in place before the Archaic (Collins 1995:381-382, 1998; Collins et al. 1989) and that these practices continued into the succeeding Late Prehistoric period (Collins 1995:385; Prewitt 1981:74). In a real sense, the Archaic period of central Texas is not a developmental stage, but an arbitrary chronological construct and projectile point style sequence. Establishment of this sequence is based on several decades of archaeological investigations at stratified Archaic sites along the eastern and southern margins of the Edwards Plateau. Collins (2004) and Johnson and Goode (1994) have divided this sequence into three parts - early, middle, and late - based on perceived (though not fully agreed upon by all scholars) technological, environmental, and adaptive changes. However, Turner and Hester (1999) and Black (1989) have designated another period at the end of the Archaic, referred to as Transitional Archaic or Terminal Archaic.

\section{Early Archaic}

The Early Archaic period ( $8,800-6,000$ B.P.) is better documented than the Paleoindian period, however a complete understanding of cultural patterns does not yet exist. Early Archaic sites are small, and their tool assemblages are diverse (Weir 1976:115-122), suggesting that populations were highly mobile and densities low (Prewitt 1985:217). It has been noted that Early Archaic sites are concentrated along the eastern and southern margins of the Edwards Plateau (Johnson and Goode 1994; McKinney 1981). This distribution may indicate climatic conditions at the time, given that these environments have more reliable water sources and a more diverse resource base than other parts of the region.
Artifact assemblages of the Early Archaic include projectile points styles such as Hoxie, Bulverde, Gower, Wells, Martindale, and Uvalde, as well as early split stem projectile points. A variety of choppers and gouges, such as the triangular, concave based bifaces known as Guadalupe tools, and the distally beveled Clear Fork unifaces are present in the archaeological record. A variety of expediency tools, often nothing more than utilized flakes, are increasingly present in the Early Archaic (Black 1989).

The construction and use of rock hearths and ovens, which had been limited during the Paleoindian period, become commonplace in the Early Archaic. The use of rock features suggests that retaining heat and releasing it slowly over an extended period were important in food processing and cooking and reflects a specialized subsistence strategy. Such a practice probably was related to cooking plant foods, particularly roots and bulbs, many of which must be subjected to prolonged periods of cooking to render them consumable and digestible (Black et al. 1997:257; Wandsnider 1997; Wilson 1930). Botanical remains, as well as other organic materials, are often poorly preserved in Early Archaic sites, so the range of plant foods exploited and their level of importance in the overall subsistence strategy are poorly understood. But recovery of charred wild hyacinth (Camassia scilloides) bulbs from an Early Archaic feature at the Wilson-Leonard site provides some insights into the types of plant foods used and their importance in the Early Archaic diet (Collins 1998).

Significant Early Archaic sites include the Richard Beene site in Bexar County (Thoms and Mandel 1992), the Camp Pearl Wheat site in Kerr County (Collins et al. 1990), and the Jetta Court site in Travis County (Wesolowsky et al. 1976).

\section{Middle Archaic}

Cultural patterns during the Middle Archaic period $(6,000-4,000$ B.P.), point toward an increased sedentary population intensively harvesting acorns, Yucca "tuna", and pecans, and hunting small and mediumsize game such as deer and turkey. The increase in the number of Middle Archaic sites and burials supports the concept of a larger, more sedentary population 
(Black and McGraw 1985; Prewitt 1981:73; Weir 1976:124, 135). Large bands may have formed at least seasonally to occupy a single area, or small groups may have used the same sites for longer periods (Weir 1976:130-131).

Sites of the Middle Archaic are numerous and often large in size. Burned rock middens are found at many sites with Middle and Late Archaic components in the Central Texas archaeological region. The development of burned rock middens toward the end of the Middle Archaic suggests a greater reliance on plant foods, although tool kits still imply a considerable dependence on hunting (Prewitt 1985:222-226). Middle Archaic projectile point styles include Bell, Andice, Calf Creek, Taylor, Nolan, and Travis. Other artifacts from the Middle Archaic are choppers, gouges, and expediency tools such as the small, bifacial and unifacial Clear Fork tools. Grinding stones and bases, referred to as manos and metates, show up in Middle Archaic artifact assemblages as well as a number of perforators, drills and awls. Chipped, polished, and ground stone artifacts are common in central Texas and surrounding regions. Less frequently encountered artifacts include tools and ornaments of bone, antler, and marine shell (Turner and Hester 2002).

Bell and Andice points reflect a shift in lithic technology from the preceding Early Archaic Martindale and Uvalde point styles (Collins 1995:384). Johnson and Goode (1994:25) suggest that the Bell and Andice darts are parts of a specialized bison-hunting tool kit. They also believe that an influx of bison and bisonhunting groups from the Eastern Woodland margins during a slightly more mesic period marked the beginning of the Middle Archaic. Though no bison remains were recovered, Bell and Andice points and associated radiocarbon ages were recovered from the Cibolo Crossing (Kibler and Scott 2000), Panther Springs Creek, and Granberg II (Black and McGraw 1985) sites in Bexar County.

Bison populations disappeared as more-xeric conditions returned during the later part of the Middle Archaic. Later Middle Archaic projectile point styles (Nolan and Travis) represent another shift in lithic technology (Collins 1995:384; Johnson and Goode 1994:27). At the same time, this shift to drier condi- tions saw the burned rock middens develop, probably because intensified use of geophytic or xerophytic plants meant the debris from multiple rock ovens and hearths accumulated as middens on stable to slowly aggrading surfaces, as Kelley and Campbell (1942) suggested many years ago. Johnson and Goode (1994:26) believe that the dry conditions promoted the spread of yuccas and sotols, and that it was these plants that Middle Archaic peoples collected and cooked in large rock ovens.

\section{Late Archaic}

During the succeeding Late Archaic period (4,000 to 1,300-1,200 в.P.), populations continued to increase (Prewitt 1985:217). As evidenced by stratified Archaic sites such as Loeve-Fox, Cibolo Crossing, and Panther Springs Creek, the Late Archaic components contain the densest concentrations of cultural materials of all these periods. Establishment of large cemeteries along drainages also suggests certain groups had strong territorial ties (Story 1985:40).

Middle Archaic subsistence technology, including the use of rock and earth ovens, continues into the Late Archaic period. Collins (1995:384) states that, at the beginning of the Late Archaic period, the use of rock ovens and the resultant formation of burned rock middens reached its zenith and that the use of rock and earth ovens declined during the latter half of the Late Archaic. There is, however, mounting chronological data that midden formation culminated much later and that this high level of rock and earth oven use continued into the early Late Prehistoric period (Black et al. 1997:270-284; Kleinbach et al. 1995:795). A picture of prevalent burned rock midden development in the eastern part of the Central Texas archaeological region after 2,000 B.P. is gradually becoming clear. This scenario parallels the widely recognized occurrence of post- 2,000 B.P. middens in the western reaches of the Edwards Plateau (Goode 1991).

The use of rock and earth ovens (and the formation of burned rock middens) for processing and cooking plant foods suggests that this technology was part of a generalized foraging strategy. Considering the amount of energy involved in collecting plants, 
constructing hot rock cooking appliances, and gathering fuel, the caloric return of most plant foods is relatively low (Dering 1999). This suggests that plant foods were part of a broad-based diet (Kibler and Scott 2000:134) or part of a generalized foraging strategy, an idea Prewitt (1981) put forth earlier. At times during the Late Archaic, this generalized foraging strategy appears to have been marked by shifts to a specialized economy focused on bison hunting (Kibler and Scott 2000:125-137). Castroville, Montell, and Marcos dart points are elements of tool kits often associated with bison hunting (Collins 1968). Archaeological evidence of this association is seen at Bonfire Shelter in Val Verde County (Dibble and Lorrain 1968), Jonas Terrace in Medina County (Johnson 1995), Oblate Rockshelter (Johnson et al. 1962:116), John Ischy in Williamson County (Sorrow 1969), and Panther Springs Creek (Black and McGraw 1985).

\section{Transitional Archaic}

As Collins (1995:384-385) notes, diverse and comparatively complex archaeological manifestations toward the end of the Late Archaic attest to the emergence of kinds of human conduct without precedent in the area. This period (2,250-1,250 B.P.), referred to as the Transitional Archaic (Turner and Hester 2002) or Terminal Archaic (Black 1989), is not recognized by all researchers. Other chronologies terminate the Late Archaic at around 1,200-1,250 B.P. (Collins 2004; Johnson and Goode 1994) to encompass this later subperiod. Johnson et al. (1962) originally designated the Transitional Archaic as a subperiod of the Archaic because of the similarities between the latest dart point types and the earliest arrow point types. Since then, however, the designation has failed to be universally accepted by researchers. In two recent chronologies for central Texas, Collins (2004) does not include the Transitional as a subperiod of the Archaic, and Johnson and Goode (1994) separate the Late Archaic into two subperiods designated Late Archaic I and Late Archaic II. The Transitional Archaic, as it is used here, closely corresponds to Johnson and Goode's (1994) Late Archaic II, but begins after the appearance of Marcos points, not with it. In this scheme, the Transitional Archaic coincides with the last two style intervals recognized by Collins (2004) (Figure 3.1) for the Late Archaic subperiod.

During the Transitional Archaic, smaller dart point forms such as Darl, Ensor, Fairland, and Frio were developed (Turner and Hester 2002). These points were probably ancestral to the first Late Prehistoric arrow point types and may have overlapped temporally with them (Hester 1995; Houk and Lohse 1993).

Several researchers believe that the increased interaction between groups at the end of the Late Archaic was an important catalyst for cultural change (Collins 2004; Johnson and Goode 1994). This change may have included increased regional stress and conflict between groups as interaction became more frequent (Houk et al. 1997a). In Bexar County, for instance, researchers noted a distinct shift in settlement patterns during this period (Houk et al. 1997a). Groups began to use hilltops as camps rather than just lithic procurement locations. These elevated locations would have provided points from which to observe game and other groups of humans as they moved through the surrounding creek valleys and upland prairies (Houk et al. 1997a).

Overall, the Archaic period represents a hunting and gathering way of life that was successful and remained virtually unchanged for more than 7,500 years. This notion is based in part on fairly consistent artifact and tool assemblages through time and place and on resource patches that were used continually for several millennia, as the formation of burned rock middens show. This pattern of generalized foraging, though marked by brief shifts to a heavy reliance on bison, continued almost unchanged into the succeeding Late Prehistoric period.

\section{Late Prehistoric Period}

Introduction of the bow and arrow and, later, ceramics into the Central Texas archaeological region marks the Late Prehistoric period (1,250-350 B.P.). Population densities dropped considerably from their Late Archaic peak (Prewitt 1985:217). Subsistence strategies did not differ greatly from the preceding period, although bison again became an important 


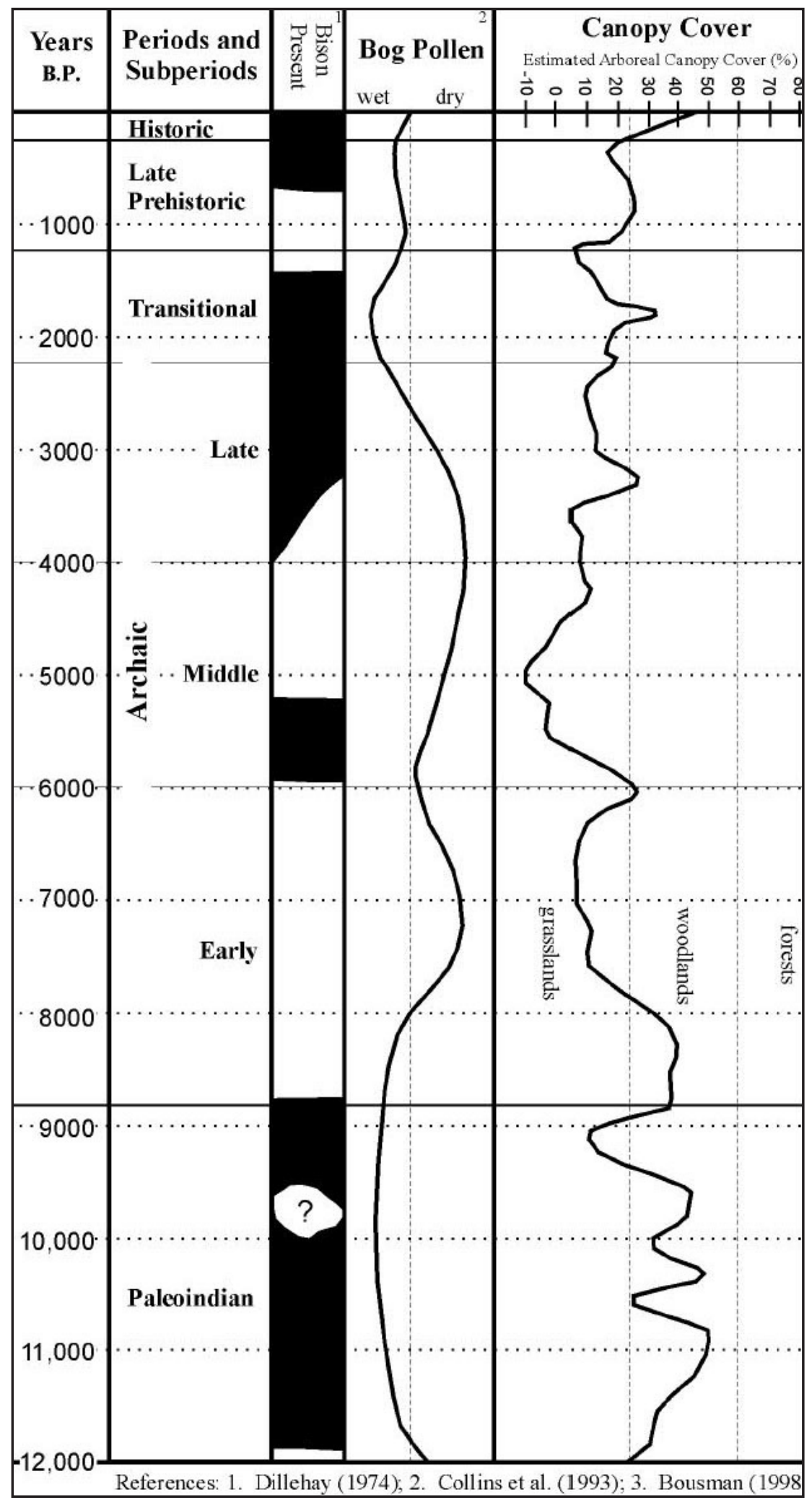

Figure 3.1. Central Texas chronology. 
economic resource during the latter part of the Late Prehistoric period (Prewitt 1981:74). Use of rock and earth ovens for plant food processing and the subsequent development of burned rock middens continued throughout the Late Prehistoric period (Black et al. 1997; Kleinbach et al. 1995:795). Horticulture came into play very late in the region but was of seemingly minor importance to overall subsistence strategies (Collins 1995:385).

Artifact assemblages include Scallorn, Perdiz, and Edwards projectile points, worked stone, thermally altered stone, hematite, bone, and shell. The points are associated with the use of the bow and arrow in the region, probably introduced sometime around $1,350-1,150$ в.P.

The earlier Austin phase (identified by Scallorn and Edwards points) and the later Toyah phase (defined through Perdiz points) divide the Late Prehistoric period throughout central Texas (Black 1989; Story 1990). These divisions were originally recognized by Suhm (1960) and Jelks (1962), and remain an accepted separation of the period. Although a distinct change in the material culture between the two phases can be seen in the archaeological record, there is some debate over the cultural underpinnings that prompted the change. The different arrow point styles (and other associated artifacts in the assemblage) may represent distinct cultural groups (Johnson 1994), but others challenge this view (e.g., Black and Creel 1997), and attribute the change to a spread of new technological ideas in response to the increase of a different economic resource in bison populations (Ricklis 1992). Nevertheless, prehistoric communities traced through cultural remains assigned to the Austin phase (1,250-650 B.P.), like many of the Archaic period cultures before them, relied on a hunting and gathering subsistence with more of an emphasis on gathering (Prewitt 1981:83). Communities attributed to the Toyah phase (650-200 B.P.) relied more on bison procurement (Prewitt 1981:84).

Around 1,000-750 B.P., slightly more-xeric or drought-prone climatic conditions returned to the region, and bison came back in large numbers (Huebner 1991; Toomey 1993). Using this vast resource, Toyah peoples were equipped with Perdiz point-tipped arrows, end scrapers, four-beveled-edge knives, and plain bone-tempered ceramics. Toyah technology and subsistence strategies represent a completely different tradition from the preceding Austin phase. Collins (1995:388) states that formation of burned rock middens ceased as bison hunting and group mobility obtained a level of importance not witnessed since Folsom times. Although the importance of bison hunting and high group mobility hardly can be disputed, the argument that burned rock midden development ceased during the Toyah phase is tenuous. A recent examination of Toyah-age radiocarbon assays and assemblages by Black et al. (1997) suggests that their association with burned rock middens represents more than a "thin veneer" capping Archaic-age features. Black et al. (1997) claim that burned rock midden formations, although not as prevalent as in earlier periods, was part of the adaptive strategies of Toyah peoples.

\section{Historic Culture History}

The Historic period (A.D. 1630 to present) in Texas roughly begins when Europeans first entered the region. From just after A.D. 1550 to the late 1600s, European journeys into the area were rare. Motivated primarily by European politics, the first Europeans into Texas were probably Spanish explorers and missionaries (Murphy 2007; Foster 1995). With the exception of these Spanish expeditions or entradas, Texas during the early Historic Period was claimed by Spain but basically remained without an established Spanish presence until around A.D. 1700 (Foster 1995; Taylor 1996).

\section{SPANISH COLONIAL/MEXICAN INDEPENDENCE PERIOD (1630-1820s)}

The Spanish Colonial period (A.D. 1630-1821) may be characterized as the initial period of Aboriginal/ European contact and European settlement in Texas. During this time San Saba County was inhabited by the Comanche and Lipan Apaches (Murphy 2007). Motivated more by a fear of French expansion than anything else, the Spanish explored and established missions in eastern and central Texas during the latter part of the seventeenth century (Foster 1995). These early overland Spanish entradas utilized 
established Indian trade routes, with the first being led by Governor Alonso de Léon (1689 and 1690) (Foster 1995). The Spanish governor of Texas, Juan Antonio Bustillo y Ceballos, led an expedition that passed through the vicinity of San Saba County in 1732. José Mares, a successful pathfinder between New Mexico and Spanish Texas, is also supposed to have crossed the area in 1788 on an expedition from San Antonio to Santa Fe (Murphy 2007).

Other than these expeditions, the area of San Saba County was not settled by Europeans until the nineteenth century. ${ }^{1}$ A group of 28 Anglo-American citizens from Austin's colony at Gonzales traveled through the eastern area of the county in December 1828 on their way to recapture a band of horses. A little earlier, the first land grants of a league each along the San Saba River were given to Spanish grantees. However, claim to the land was only on paper, and no Spanish settlers came to San Saba County. Additionally, a part of the county was included in one of the grants ceded to Stephen F. Austin under the Mexican empresario system, and the Beall grant, which overlapped the Austin grant, also included a portion of San Saba County. As with the previous grants, individuals took legal but not physical possession of the land (Murphy 2007).

\section{RePUblic of TEXas/Pre-CiVIL War (1836-1860)}

During the Republic of Texas era, from 1836-1845, the San Saba County area remained an Indian stronghold until the 1870s. San Saba County was first mentioned in Republic of Texas documents in 1842, when a petition was made by Henry Francis Fisher, Burchard Miller, and Joseph Baker to settle 1,000 immigrant families of German, Dutch, Swiss, Danish, Swedish, and Norwegian ancestry in Texas, under the auspices of the San Saba Colonization Company. The grant included more than three million acres between the Llano and Colorado rivers (Loving 1934). However, few settlers arrived in the area and most soon moved to New Braunfels or Fredericksburg, selling their grants in the Fisher-Miller tract.

On December 29, 1845, Congress signed the Texas Admission Act, the result of several years of annexation debate. A few months later on February 19 , members of the newly formed state government conducted a ceremony in front of the Capitol at Austin marking Texas' official annexation into the Union and the end of the Republic of Texas (Campbell 2003:186; Miller and Faux 1997:78).

After annexation, San Saba began to be developed by permanent settlers, including the Harkey family, who settled at Wallace and Richmond creeks in the fall of 1854, and the David Matsler family, who moved from Burnet County and settled on Cherokee Creek that same year (Murphy 2007). San Saba County was organized from Bexar County in 1856 and was named after the San Saba River. The act establishing the county was passed by the Sixth Legislature and approved on February 1, 1856.

\section{The Post-CiVIL War to EARLY TWENTIETH Century (1865-1920)}

The years between 1860 and 1920 marked a period of slow growth in the county. The 1860 census documented a population of 913 , with 89 listed as slaves. The following census after the Civil War the number of African Americans grew to 144, while whites increased to 1,281. Lawlessness became a problem during the $1880 \mathrm{~s}$, and the county experienced a period of "mob rule." Citizens formed an anti-mob organization, but competing groups conducted essentially open warfare. After several people were killed, the Texas Rangers were dispatched to the area and order was eventually restored (Murphy 2007). At the turn of the century the county population was 7,569 , but the percentage of blacks decreased. By 1920 the population grew to 10,045. San Saba County was essentially a rural agricultural area, and the number of farms grew from 34 in 1860 to 1,268 in 1920. Between 1860 and 1900 the number of

\footnotetext{
${ }^{1}$ Mission Santa Cruz de San Sabá, founded by Franciscan Missionaries in 1757, and Presidio San Luis de las Amarillas (popularly known as San Sabá Presidio) founded in April 1757, are located in Menard County. The roads between these sites and San Antonio ran southwest of San Saba County (Bolton 1916).
} 
cattle jumped three-fold, and the number of sheep increased almost 900 percent. Wheat and oats originally emerged as primary crops, and peaches were produced in significant numbers after 1900. Edmund E. Riesen, an Englishman who moved to San Saba County in 1874, developed the harvesting of pecans that led San Saba County to proclaim itself Pecan Capital of the World (Murphy 2007).

In 1886 the Santa Fe Railroad completed a route that came within 21 miles of the town of San Saba, but it was 25 years before railroad officials were convinced that the level of agricultural production merited a line extension. Not until August 1911 did the Lometa-Eden branch cross the county, with stations at San Saba, Algerita, Richland Springs, and Hall Valley (Murphy 2007). Highway construction in the county was equally slow; it was the last county in Texas to have its roads paved.

\section{Depression ERa to Post-World War II (1930-1950s)}

The county population totaled 10,273 in 1930 and increased to 11,012 in 1940 . That same year there were 11,327 cattle, 127,207 sheep, and 63,911 goats counted in the county. Oats, pecans, and peaches continued to hold strong, but wheat production was surpassed by sorghum and corn, with 70,032 bushels of sorghum and 190,633 bushels of corn harvested in 1940. However, difficult agricultural conditions in the 1920s followed by the Great Depression affected farming in the county. Although the number of farms increased in 1930, their overall value decreased by 5 percent between 1920 and 1930. Approximately half of the county farms were worked by tenants (Murphy 2007).

However, the down times had not ended there. By 1940 the number of farms had declined, and their value decreased by another 15 percent. A recordbreaking flood of the San Saba River in July 1938 caused destruction throughout the county, and a prolonged drought from 1953 to 1956 did extensive harm to the agricultural economy. Between 1950 and 1959 the number of farms decreased from 1,105 to 784 , and the county's population declined to 8,666 by 1950 and to 5,540 by 1970 (Murphy 2007). The number of farms never reached above 1,000 in the later twentieth century, and the population remained small, about 5,000-6,000 people. 



\title{
Chapter 4
}

\section{Methods and Research Design}

\author{
Mindy L. Bonine
}

\section{INTRODUCTION}

At the time of site 41SS164's discovery within the ROW of CR 228, it was determined that further investigations were needed to establish the integrity and information potential of archaeological deposits that would be impacted by the proposed undertaking. As such, SWCA was tasked with developing a research design, methodology, and scope of work for significance testing at site 41SS164 that would determine if the site was considered eligible under Criterion D of the NRHP or for listing as an SAL. The research design was based around general research issues given that very little was known about the site prior to testing, and the methodology and scope of work were designed to obtain the best information possible given the limitations of the site setting and land access constraints. As the explanation of the methodology and scope of work will be better understood within the context of the site setting, a brief description is presented below.

\section{Site Setting}

The site is situated on a relatively flat $T_{2}$ terrace overlooking Richland Springs Creek. The terrace has been impacted by the current CR 228 roadway, the bridge, a dirt road leading to the property on the southeast side of the bridge crossing, and the remains of a possible low water crossing indicated by several gullies on the northeast and southwest banks of the creek (see Figure 2.4). Based on the current topography, it seemed unlikely the site extends further north beyond the ROW of CR 228, as the gullies had significantly altered the bank slope, and investigations by Horizon on the west side of Richland Springs Creek indicated that cultural material did not extend to that side. Thus, the site was determined to be only on the east side of the creek, located on the south side of the road ROW and possibly under the road itself.

\section{Testing ResearCh DESIGN}

SWCA's initial research design was based on information provided by Horizon regarding the nature of the archaeological deposits at 41SS164. The project's stated goals were to systematically identify, record, and assess the significance of archaeological materials discovered at 41SS164. Levels of artifactual and contextual integrity, chronology, potential data yield, and preservation potential were key criteria in this evaluation. The investigations focused on two main issues: integrity and potential data yield.

\section{RESEARCH ISSUE 1: INTEGRITY OF THE Archaeological Deposits}

A primary factor in determining the significance of site 41SS164 was the integrity of its archaeological deposits. One goal of these investigations was to acquire data on depositional context, define any relationships between natural strata and subsurface cultural features/deposits, and determine if the integrity of the buried deposits is sufficient to establish relative and/or absolute chronological dates for any subsurface components and to subdivide recovered materials into analytical units relevant to specific research questions. Therefore, excavations were performed with sufficient detail and observations to provide for identification and documentation of relevant analytical units. Several charcoal samples were collected to establish a chronology for the components at the site and to evaluate integrity (i.e., are the deposits compressed, are they mixed, are they stratified?).

\section{Research Issue 2: Potential Data YIELD}

A secondary factor in determining the significance of the site was the potential for additional excavations 
to recover meaningful data in terms of artifacts and other special samples that could be used to address specific research questions related to one or more historic contexts during data recovery. At this stage in the process, with so little known about the site, proposing detailed research questions was premature. Thus, general questions relevant to any archaeological investigation were addressed by the testing project, including site size, function, and chronology. Preservation potential for macrobotanical or faunal remains was also a criterion used to evaluate potential data yield. Two gallon-sized bags of soil matrix were collected from one of the features to provide macrobotanical samples for analysis.

\section{EVALUATING SigNificanCE}

Prior to testing, SWCA proposed that for the site to be found significant under Criterion $\mathrm{D}$, the deposits must demonstrate sufficient integrity and data yield potential to address specific, detailed research questions that would contribute to the understanding of the regional prehistory within the framework of one or more historic contexts. If the site had good integrity but a stratigraphically dispersed, low density of artifacts, no dateable materials, no features, and poor preservation of organics, it would be less likely to contribute new or important information. Similarly, if the site had abundant artifacts and materials but poor archaeological integrity, eligibility would be contraindicated. In either case, site eligibility is hinged on its ability to address one or more explicit, nontrivial questions about prehistory.

\section{SCOPE OF Work}

The methodology and scope of work were designed to provide the information necessary to address the research issues described above and make a determination as to site 41SS164's integrity and information potential. The proposed undertaking would gradually expand the ROW from 50 feet to about 80 feet at the site location on the eastern bank of Richland Springs Creek, and all of the new ROW would be taken from the north side of the road (see Figure
1.5). The site both within the existing ROW and the proposed expansion area to the north would be impacted. However, as the new ROW is located where several gullies cut into the bank of Richland Springs Creek, the potential for intact cultural deposits in that area were low. Thus, all of the significance testing investigations were conducted within the existing 50-foot ROW of CR 228.

\section{Texas Antiquities Permit Application}

As the initial step in the investigation, SWCA completed a Texas Antiquities Permit application to conduct the fieldwork for the project. As part of this task, SWCA wrote a preliminary scope of work that addressed artifact collection, site mapping, feature documentation, and special samples. Included in the scope of work was a task to complete an interim report that provided a summary of the excavations, stratigraphy, integrity, and recovered materials, and made recommendations for additional work, if any. A more thorough final report was completed later, including a description of the field and analytical methodologies that were used, background cultural and environmental settings, details of the results of the laboratory analysis, and a discussion of the site within a larger prehistoric context.

\section{Archaeological Testing}

SWCA's testing investigations were designed with two information gathering techniques: 1) backhoe trenching to define the horizontal and vertical site boundaries within the TxDOT ROW, and 2) hand excavation units to determine the research potential of the cultural deposits at site 41SS164. The scope of work called for the removal of the overburden (the roadbed and obvious fill material) as needed via mechanical excavation. Then, archaeologists would supervise the excavation of an approximately $10-\mathrm{m}$ long mechanical trench to approximately $1.5 \mathrm{~m}$ in depth to examine the natural and cultural stratigraphy at the site and to geoarchaeologically evaluate the deposits. Following this, a 50-x-50-cm column sample would be strategically placed and hand excavated to quantify the archeological data resulting from the mechanical trench excavations. The data from the trench and the column sample were to be 
used to guide test unit placement and frame expectations regarding subsurface components. However, as detailed in Chapter 5, the length of the backhoe trench and the purpose of the $50-\mathrm{x}-50-\mathrm{cm}$ column sample were slightly altered to accommodate the specifics of the site setting.

Once the column sample was completed, the scope of work called for archaeologists to dig $3 \mathrm{~m}^{3}$ of hand excavation units, allocated according to the Principal Investigator's and Project Archaeologist's professional judgment. Hand unit excavations were intended to focus on the area between Horizon's mechanical trench and the roadway in the southeastern bridge quadrant. Excavation of the hand excavation units, artifact collection, site mapping, feature documentation, and collection of special samples were all to be conducted using standard techniques approved by the THC. As detailed in Chapter 5, the areas under the roadway were selected for placement of the hand excavation units after features were uncovered in that area.

If necessary, a contingency was established to excavate up to $2 \mathrm{~m}^{3}$ of deposits to assist in determining eligibility, document a feature, or to plan effectively for additional work However, additional excavations were not deemed necessary based on the results of the $3 \mathrm{~m}^{3}$ hand excavation units.

\section{SITE MAPPING}

The locations of all excavation units and features at site 41SS164 were carefully mapped using a digital theodolite during the testing project. The excavations and site boundaries were related to existing roadway limits, modern construction features, the existing topography, and natural features, including Richland Springs Creek. An arbitrary vertical datum with an elevation of $100 \mathrm{~m}$ was established at the site and all subsequent measurements were based off this elevation. A secondary datum was established on the bridge to measure features outside the range of the primary datum. Given the very narrow area in which the excavations were to take place, no grid was established. The horizontal placement of the hand excavation units was based on topography and anticipation of intact deposits, and they were oriented parallel to the backhoe trench.

\section{Artifact Collection and Special SAMPLES}

All artifacts recovered from each provenience unit were collected, bagged, and labeled accordingly. Burned rock was quantified by size category, counted, and weighed in the field, but not collected. Special samples were systematically collected from appropriate contexts across the site. Special samples included materials for radiocarbon dating (from features, geomorphic units, and other appropriate contexts, with AMS dating to be used when necessary) and matrix samples for flotation and/or fine screening (from features). Unfortunately, no appropriate contexts for the collection of pollen/phytolith samples or burned rock samples for lipid residue analysis were found during the testing investigations. 



\section{Chapter 5}

\section{Results OF InVESTIGATION}

Mindy L. Bonine, Michael R. Chavez, and Charles Frederick

\section{INTRODUCTION}

This chapter summarizes the results of the testing investigations, including a description of the daily chronology of excavations, a summary of the level of effort, a discussion of the site size and natural stratigraphy, and an account of the cultural components, including a description of Features 1 and 2.

\section{NarRation ANd Summary OF THE EXCAVATIONS}

In Chapter 4, a description of the methodology and scope of work was presented, which was based on what was known about the site before the testing investigations were conducted. Below is a description of how that scope of work was carried out, and describes the progress of the investigations day-by-day as well as any changes to the scope that were necessary based on the realities of the situation.

\section{Chronology of EVENTS}

SWCA began testing on June 6, 2006 (Figure 5.1). Immediately upon arrival to the site, it was clear that the shoulder between the roadbed and the private property fence was too narrow to place a backhoe trench, so the southern edge of the roadbed was mechanically removed, and the first backhoe trench (BHT 1) was excavated to 1.5-2.0 $\mathrm{m}$ below the surface. The western end of this trench was placed only about $4 \mathrm{~m}$ east of the edge of the steel truss bridge (Figure 5.2). The gravel roadbed and obvious fill, indicated by its yellow-red color, was also removed in a strip along the northern side of the trench to facilitate the excavation of the hand excavation units. Discovery of archaeological deposits and the geomorphological analysis would be greatly enhanced with a trench longer than $10 \mathrm{~m}$, and a decision was made to extend the east-west trench much farther to the east. Approximately half of the backhoe trench was excavated the first day, and the machine and operator returned the following day to complete the excavations.

Meanwhile, trench profiles were initiated, and the transit and an arbitrary 100-m datum were set up. The trench revealed several layers of road fill to depths of $80 \mathrm{cmbs}$. Interestingly, discrete layers of burned sandstone could immediately be seen in both sides of the backhoe trench within the upper part of the natural strata, and these deposits were selected as the focus of the hand excavation units. At least two layers were seen in the trench, and the heaviest concentration of each layer guided the placement of the first $1-x-1-m$ hand excavation unit (TU 1), situated on the northern side of BHT 1. 
5-2 Chapter 5

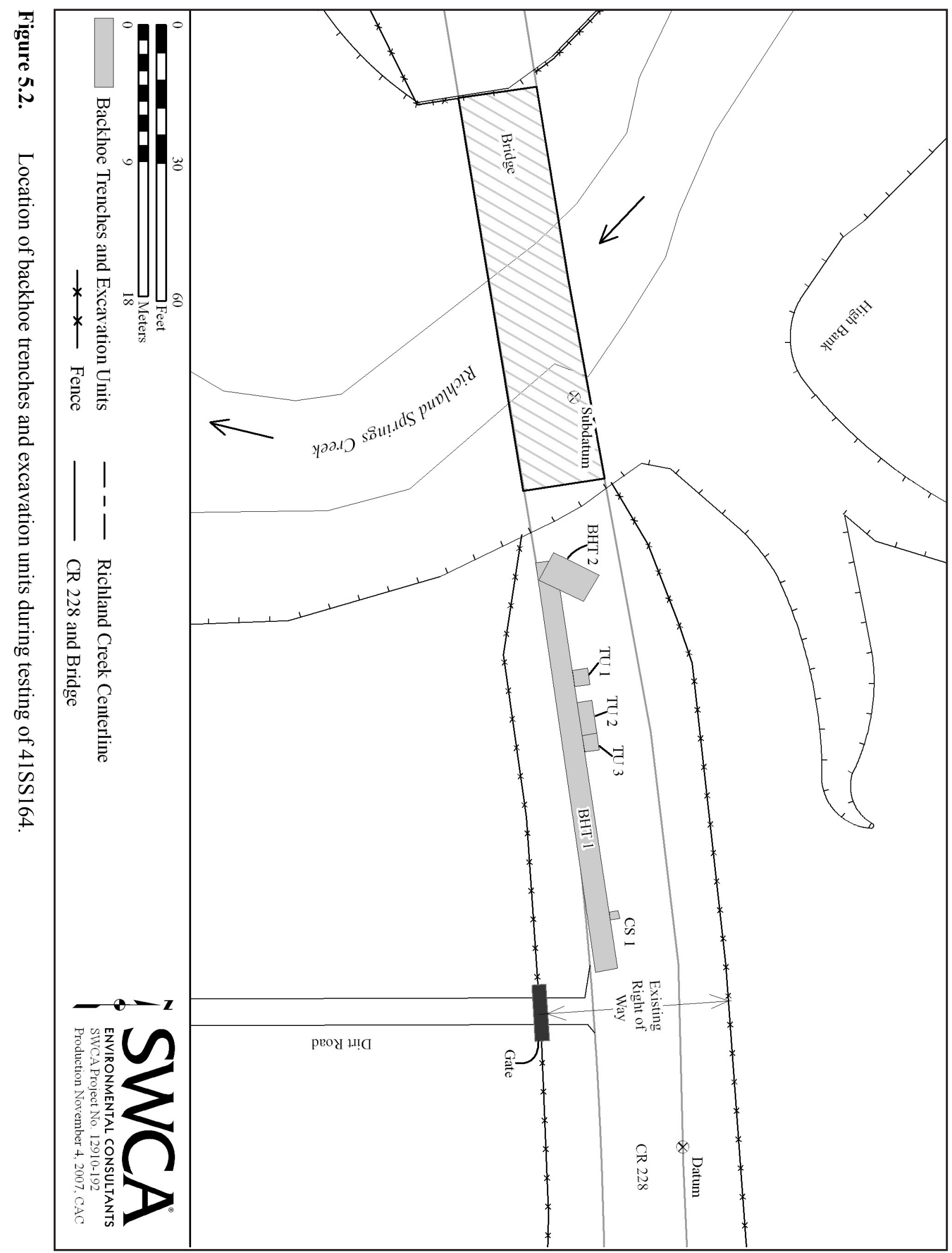


The next day (June 7, 2006), the backhoe returned for additional excavation of BHT 1, which was lengthened to $25.2 \mathrm{~m}$. The trench was monitored to ensure the lowest cultural deposit was uncovered, which seemed to rise in elevation as the trench proceeded east (Figure 5.3). Additional areas north of the trench were cleared of the roadbed and fill material (Figure 5.4).

TU 1, set up the previous day and excavated one $10-\mathrm{cm}$ level, was excavated to a depth of $98.20 \mathrm{~m}$. TU 2, a 1-x-2-m excavation unit, was set up $1 \mathrm{~m}$ to the east of TU 1 and excavated to a depth of 98.00 $\mathrm{m}$. An analysis of the profile in the BHT 1 revealed two identifiable features: Feature 1, a small burned sandstone cluster located at the bottom of the trench on the western side of the site, and Feature 2, a thin lens of burned sandstone with pockets of stacked material extending for about $8.5 \mathrm{~m}$ at an angle sloping towards the creek. As clear layers of cultural material were located in the backhoe trench, the $50-\mathrm{x}-50-\mathrm{cm}$ column sample, intended to guide the placement of the excavation units, was reserved to investigate another section of the site at a later date.

On the second day, the geomorphological assessment of the cultural deposits was refined, and it was determined that an interface layer between the recent road-related deposits and in situ alluvium was not an alluvial deposit, but perhaps soil brought in from another location that just happened to contain cultural material (see below). The mixing of both prehistoric and historic artifacts in this zone, as well as the presence of numerous gravels in the matrix from TU 1, supported this assessment.

Also during the second day of fieldwork, the owner of the land bordering the south side of the road drew our attention to the presence of a concrete low-water crossing immediately below and in line with the existing bridge. He insisted that a low water crossing was present before the bridge was constructed, and that it was in the same exact place as the bridge. If true, it would mean there were likely very few alluvial deposits left in situ in the northern half of the road. Thus, it was possible that a significant amount of the site within the ROW might have been destroyed, and this information would be crucial in determining the overall integrity of the site. However, the topography in the immediate vicinity of the site suggests the road did not cross the creek in a straight line, but rather the western road segment was aligned slightly to the south, and the eastern section was oriented slightly to the north. Both segments had been straightened to approach the existing bridge. This, coupled with multiple gullies on the northeast and southwest sides of the bridge, led the researchers to think the original ford in this location crossed Richland Springs Creek diagonally, rather than on the same orientation as the modern road (see Figure 2.4). To resolve this issue, it was decided that a second trench, excavated perpendicular to the road, would be required to assess the integrity of the deposits across the ROW.

Over the course of the next five days (June 8-12, 2006), the excavation of TUs 1 and 2 continued, and TU 3 was introduced to expand the plan view of Feature 2 (97.9-97.6 m). TU 4 was excavated to explore the area beneath Feature 2. Feature 2 was thoroughly explored through excavation, photogra-

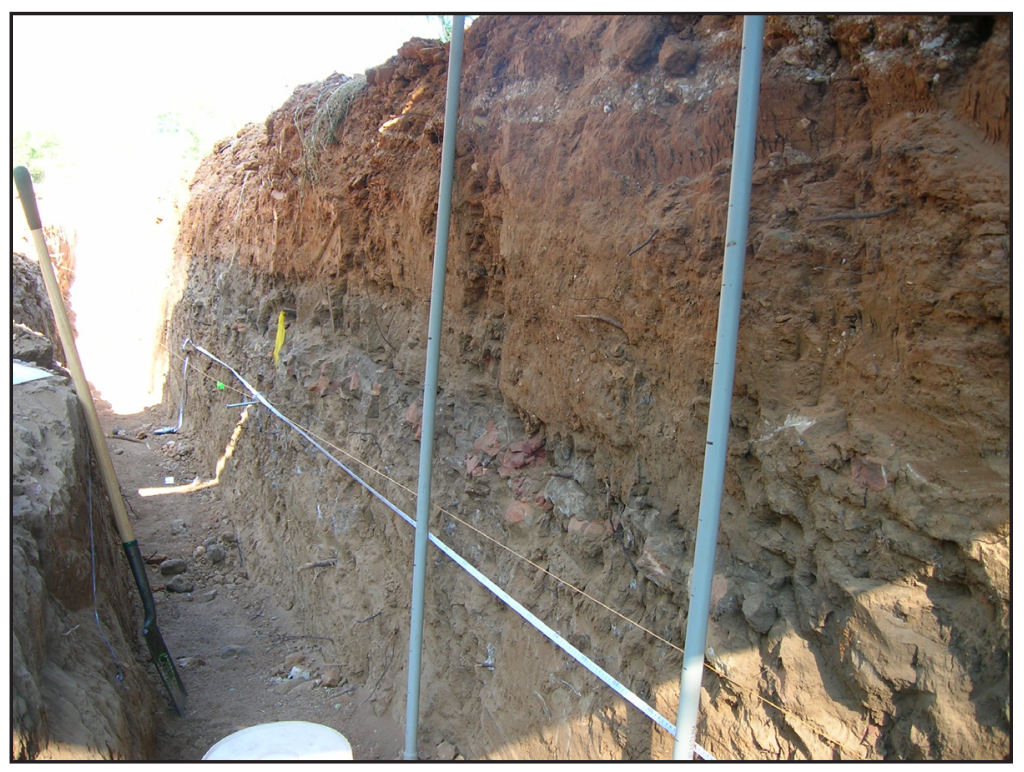

Figure 5.3. South elevation of BHT 1, opposite TUs 2 and 3. Note cultural material just above the string line (Feature 2); the yellow flagging tape indicates the location of a historic iron bar. 


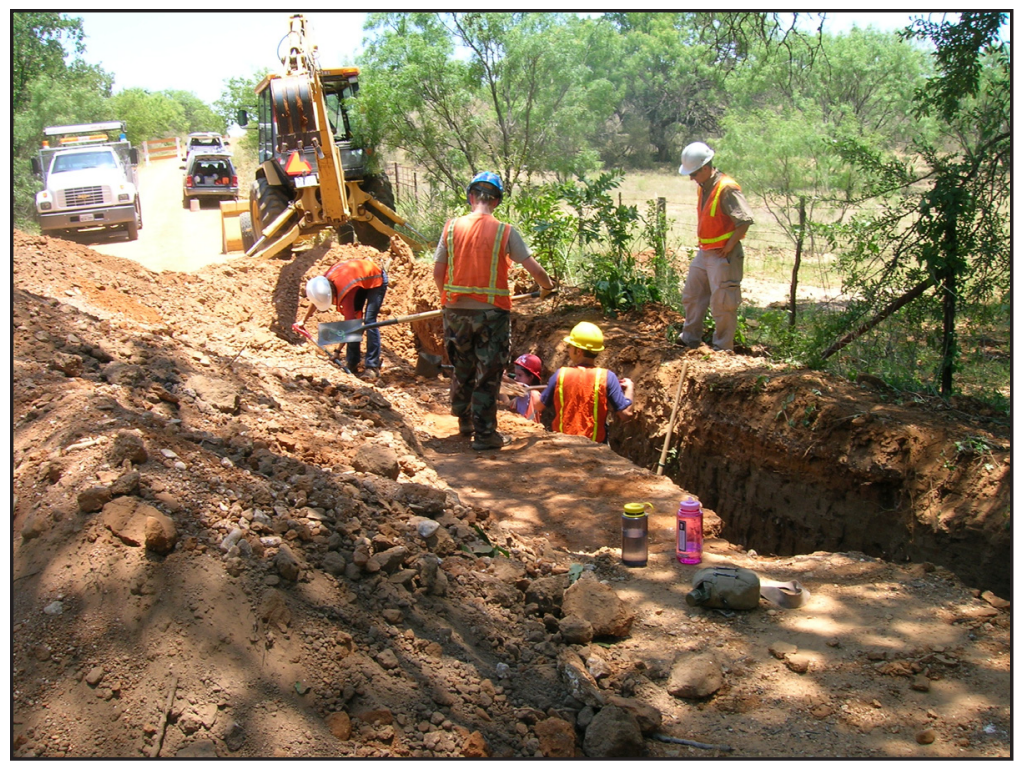

Figure 5.4. Clearing of the roadbed on the north side of BHT 1 prior to hand excavations. Photo facing southeast.

phy, mapping, sampling, and collection. The south wall of BHT 1 was also profiled once more, concentrating on detailing the cultural zones. Additionally, as the eastern end of the site had not been investigated through hand excavation, the $50-\mathrm{x}-50-\mathrm{cm}$ column sample was placed about $10 \mathrm{~m}$ to the east of TU 3 on the northern side of BHT 1. This unit was dug in $20-\mathrm{cm}$ levels to $120 \mathrm{~cm}$ in depth, reaching the bottom of the trench.

On the last day of excavations, June 13, 2006, a second trench was excavated perpendicular to the road, at the western end of BHT 1. First, BHT 1 was filled in and the surface leveled. Then, BHT 2 was excavated. It was not possible to excavate the trench exactly 90 degrees to the existing road, as there was insufficient room within the ROW. Thus, BHT 2 was excavated 27 degrees off of magnetic north for a length of $3.6 \mathrm{~m}$, to a depth of $1.6 \mathrm{~m}$. The trench was placed to clip the northern edge of the previous trench to observe the changes in the stratigraphic layering and confirm the presence of cultural material. The geomorphologist returned at this time to examine BHT 2.

The trench demonstrated that a low water crossing or gully-like feature was not present under the northern side of the roadway, and cultural material was seen in the trench wall about $1.5-1.6 \mathrm{~m}$ below the road surface. Thus, it is most probable that the site extends beneath the entire existing road, and continues north of the road to be truncated by the cutbank just northeast of the bridge (see Figure 2.4). This is the area where new ROW will be taken to build the wider bridge. The soils from BHT 2 were not described, as the strata within it were identical to those exposed at the west end of BHT 1. However, BHT 2 confirmed that the old low crossing is not in the same location as the current roadway, and it was more likely diagonal to the creek. Thus, the concrete fragment of the low water crossing under the bridge has been moved from its original location either during or after the construction of the existing bridge. With this issue resolved, BHT 2 was filled in and the ground leveled.

\section{SUMMARY OF LEVEL OF EFFORT}

In sum, SWCA conducted backhoe trenching, hand excavations, special sampling, and other documentation at the project area. The minimum requirements in the scope of work were met with $3.28 \mathrm{~m}^{3}$ of hand excavations, the excavation of two backhoe trenches to a depth of 1.5-2.0 m, the placement of one 50$\mathrm{x}-50-\mathrm{cm}$ column sample (totaling $0.25 \mathrm{~m}^{3}$ ), and the collection of all encountered artifacts and special samples. As shown in Table 5.1, the hand excavations focused on the deposits containing cultural material, which later turned out to be separated into a disturbed interface layer deposited in the historic era and an intact prehistoric deposit. Roughly equal amounts of material were excavated from each deposit.

In addition to the hand excavations, the testing project excavated two backhoe trenches and profiled the southern wall of the 25.2-m long trench. Features 1 and 2 were located in this trench, and the size of each feature is generally determined by their profiles. BHT 1 was excavated to a variable depth of $1.5-2.0 \mathrm{~m}$, and BHT 2, excavated with a wider 5-foot bucket, was dug to a depth of $1.6 \mathrm{~m}$ and a length of $3.6 \mathrm{~m}$. Feature 1 was not investigated as it was located at 
Table 5.1. Excavated Volume of 1-x-1-m Excavation Units and Column Sample at 41SS164

\begin{tabular}{|c|c|c|c|c|}
\hline \multirow{2}{*}{ Test Unit } & \multicolumn{4}{|c|}{ Excavated Volume $\left(\mathbf{m}^{\mathbf{3}}\right)$} \\
\cline { 2 - 5 } & Road-Related Deposits & Interface Deposit & In Situ Alluvium & Total \\
\hline 1 & 0.15 & 0.50 & 0.60 & 1.25 \\
\hline 2 & 0.08 & 0.90 & 0.60 & 1.58 \\
\hline 3 & 0.00 & 0.15 & 0.10 & 0.25 \\
\hline 4 & 0.00 & 0.00 & 0.20 & 0.20 \\
\hline Column Sample & 0.00 & 0.00 & 0.25 & 0.25 \\
\hline Excavation Total & $\mathbf{0 . 2 3}$ & $\mathbf{1 . 5 5}$ & $\mathbf{1 . 7 5}$ & $\mathbf{3 . 5 3}$ \\
\hline
\end{tabular}

the very edge of the ROW and at a significant depth, but Feature 2 was explored with the hand excavation units. Finally, the eastern side of the site was examined with one 50-x-50-cm column sample, the majority of which was excavated in $20 \mathrm{~cm}$ levels below the intact prehistoric surface.

\section{Results}

\section{SITE SIZE}

The exact dimensions of site 41SS164 are unknown at this time because the site extends beyond the limits of the ROW. The Horizon survey primarily documented the site on the southern side of the road within the ROW and extending into private property (Clark and Owens 2006). A second backhoe trench (BHT 2) indicates that the site likely extends under the roadway and beyond it to the north, including the area in which new ROW will be taken to widen the bridge. The known extent of the site is at least $15 \mathrm{~m}$ north-south by $26 \mathrm{~m}$ east-west. The north-to-south dimension of the site is based on accumulated data derived from the SWCA investigations presented here and the previous survey by Horizon. The eastto-west dimension is derived from SWCA's testing project. It is based primarily on the length of BHT 1 and the distance from the creek bank to the edge of the backhoe trench. Given the presence of, but very low density of cultural deposits in the column sample unit, it is interpreted to be located near the eastern limit of the site. Cultural material seen in BHT 1 to the east of the column sample was very sparse.
The vertical limits of the site were determined from backhoe trench and test unit data from the SWCA testing investigation. These units were placed within the roadway of CR 228. As the cultural material decreases in depth as one proceeds eastward, the westernmost end of the site is the lowest at $150 \mathrm{cmbs}$. In this portion of the site, much of the overlying layers are part of the roadway fill; the interface layer is also quite thick in this location. Proceeding east, the cultural material decreases in depth to about 60 $\mathrm{cmbs}$ at the easternmost end. The interface layer has disappeared by this point, and only the roadway fill tops the cultural deposit. The undisturbed cultural deposits of the site range in thickness from 50-65 $\mathrm{cm}$.

\section{NATURAL STRATIGRAPHY}

SWCA's geomorphologist evaluated the stratigraphy of the site primarily by means of a single backhoe trench (BHT 1), roughly $25.2 \mathrm{~m}$ long, oriented parallel and adjacent to the southern side of the existing county road. This trench was started a few meters east of the bridge and extended to just west of a gate in the barbed wire fence that borders the southern side of the road, near the rear of the $\mathrm{T}_{2}$ surface. The geomorphologist also searched for the low water crossing and examined BHT 2, confirming the similarity of the deposits to BHT 1. As such, he did not describe/profile BHT 2 in detail.

\section{Stratigraphic Results}

The southern wall of BHT 1 was cleaned and drawn (Figure 5.5) and the strata described (correlating descriptions for Figure 5.5 are found in Table 5.2). All 


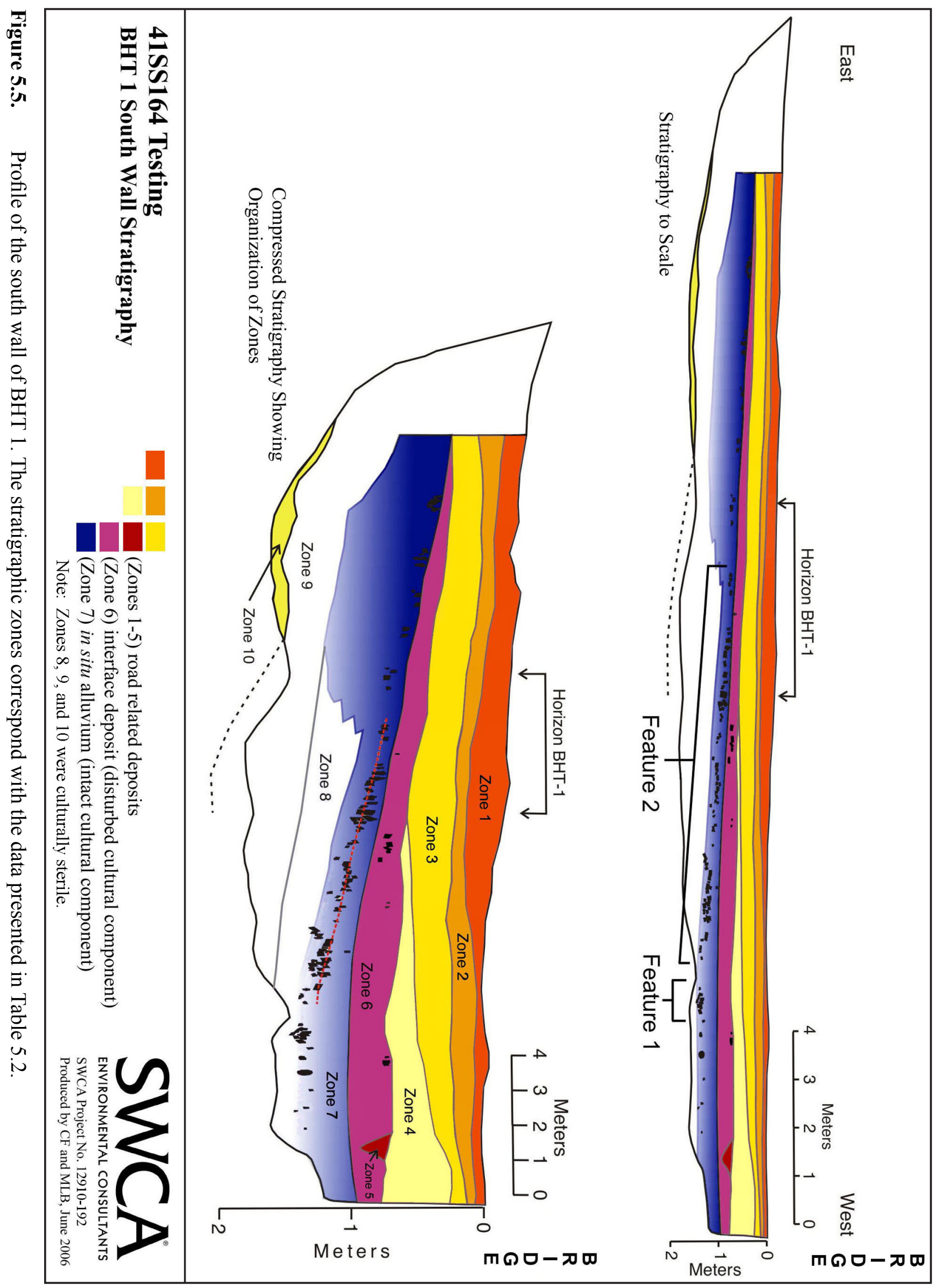


Table 5.2. Description of the Deposits Illustrated in Figure 5.5

\begin{tabular}{|c|c|c|}
\hline Zone & Horizon & Description \\
\hline 1 & C & $\begin{array}{l}\text { Dark reddish brown ( } 5 \text { YR } 3 / 4 \text {, moist; } 7.5 Y R \text { R/4, dry) slightly gravely sand, loam and clay, very hard } \\
\text { to loose, weak very coarse platy structure, abrupt smooth boundary, violently effervescent, } 5-20 \% \\
\text { coarse fragments, multiple variable texture thin beds, often laminated, runoff from road, prominently } \\
\text { bedded in places. }\end{array}$ \\
\hline 2 & C & $\begin{array}{l}\text { Brown ( } 7.5 Y R \text { R/4, moist, } 7.5 Y R 5 / 4 \text {, dry) gravelly sandy clay, loose, single grained, abrupt wavy } \\
\text { boundary, violently effervescent (overall), introduced caliche road base, derived from an ancient } \\
\text { alluvial deposit formed in a gravel, highly variable texture, includes fragments of } \mathrm{Bt} \text { and } \mathrm{K} \text { horizons; } \\
\text { some gravel sized clasts are fragments of indurated } \mathrm{K} \text { horizon, others siliceous gravels with } 2-3 \mathrm{~mm} \\
\text { thick pendant cements. }\end{array}$ \\
\hline 3 & $C$ & $\begin{array}{l}\text { Yellowish red ( } 5 \text { YR } 4 / 6 \text {, moist, } 5 \text { YR } 5 / 8 \text {, dry) loam to sandy clay, hard, strong fine angular blocky } \\
\text { structure, abrupt smooth boundary, non-effervescent, this is a road leveling fill that was derived } \\
\text { from an ancient Bt horizon formed in a sandy parent material, it is clearly reworked by water to east } \\
\text { where it is often thin bedded and laminated, and more resembles redeposited aggregates near the } \\
\text { bridge. }\end{array}$ \\
\hline 4 & C & $\begin{array}{l}\text { Brown (10YR 4/3, moist; } 10 Y R 5 / 3 \text {, dry) loam, slightly hard, weak clear subangular blocky structure, } \\
\text { abrupt smooth boundary, strongly effervescent, includes a few pieces of prehistoric cultural mate- } \\
\text { rial, as well as a few pieces of recent cultural material; this deposit is an introduced fill that forms a } \\
\text { prominent wedge which is thickest adjacent to the bridge and pinches out to the east, forming the } \\
\text { bulk of the grade leading up to the bridge. }\end{array}$ \\
\hline 5 & $C$ & $\begin{array}{l}\text { Dark reddish brown (5YR } 3 / 4 \text {, moist; } 5 \text { YR } 4 / 6 \text {, dry) slightly gravelly loam, slightly hard, moderate } \\
\text { coarse subangular blocky structure, abrupt smooth boundary, non-effervescent, few calcium car- } \\
\text { bonate filaments, common thin discontinuous coats of calcium carbonate on ped faces, this deposit } \\
\text { fills a prominent but narrow u-shaped linear feature that is oriented normal to the existing road, and } \\
\text { the fill appears to have been derived from an ancient Bt horizon formed in sandy parent material. }\end{array}$ \\
\hline 6 & ACk & $\begin{array}{l}\text { Very dark grayish brown (10YR 3/2, moist; 10YR 4.5/3, dry) loam, slightly hard, weak coarse sub- } \\
\text { angular blocky structure, abrupt smooth boundary, matrix is non-effervescent, common thin discon- } \\
\text { tinuous coats of calcium carbonate on ped faces (especially close to bridge), includes numerous, } \\
\text { often large, burnt rocks, bits of lithic debitage, as well as rounded aggregates of reddened earth, } \\
\text { and metal debris, upslope this unit is laminated but becomes more massive towards the bridge; at } \\
\text { first glance this was thought to be a natural deposit, but on whole it looks more like a fine earth fill } \\
\text { derived from a late Holocene alluvial deposit within which there was an archaeological site. }\end{array}$ \\
\hline 7 & $2 A k b$ & $\begin{array}{l}\text { Very dark grayish brown (10YR 3/2, moist; 10YR 4/2, dry) loam, slightly hard, moderate weak } \\
\text { subangular blocky structure, clear smooth boundary, slightly effervescent to non-effervescent, few } \\
\text { calcium carbonate filaments, few granules. }\end{array}$ \\
\hline 8 & $2 A B k$ & $\begin{array}{l}\text { Brown ( } 7.5 Y R \text { R 4/4, moist) loam to sandy clay, hard, strong coarse prismatic structure parting to } \\
\text { strong coarse angular blocky structure, diffuse smooth boundary, matrix is non-effervescent, few } \\
\text { calcium carbonate filaments and common thin discontinuous coats of calcium carbonate on ped } \\
\text { faces, few granules. }\end{array}$ \\
\hline 9 & 2Bk1 & $\begin{array}{l}\text { Yellowish brown (10YR } 5 / 4 \text {, moist) loam to silt loam, very friable, moderate to strong, medium sub- } \\
\text { angular blocky structure, clear smooth boundary, matrix is non-effervescent, few calcium carbonate } \\
\text { filaments, common thin discontinuous coats of calcium carbonate on ped faces, }\end{array}$ \\
\hline 10 & 2Bk2 & $\begin{array}{l}\text { Brown ( } 7.5 \text { YR } 5 / 4 \text {, moist; } 10 Y R \text { 8/2, dry) silt loam, very friable, weak coarse subangular blocky } \\
\text { structure, violently effervescent, many medium to coarse friable irregular shaped very pale brown } \\
\text { (10YR } 7 / 4 \text { moist; white } 10 \text { YR } 8 / 1 \text { dry) masses of calcium carbonate, as well as abundant finely dis- } \\
\text { seminated calcium carbonate in the matrix; Stage II+ calcic horizon. }\end{array}$ \\
\hline
\end{tabular}


but one of the deposits revealed by this trench were easily assignable to one of two groups: 1) recent road-related deposits, and 2) in situ alluvium. The stratum situated at the interface of these two groups shared attributes of both deposits, and it was thought to be a disturbed cultural level, with historic and prehistoric debris mixed with the road related fill. A total of 10 zones were defined, with Zone 1 located at the ground surface and Zone 10 at the bottom of BHT 1 . Zones 8, 9, and 10 were culturally sterile.

\section{RoAD-RELATED DEPOSITS}

The upper five strata revealed by BHT 1 were clearly related to construction and maintenance of CR 228 and had been deposited during and after the construction of the present bridge. These deposits were of variable lithology, but generally have been derived from ancient alluvial deposits, a fact which could easily be determined from their color, clast composition, or inherited pedogenic features. Some of these deposits bore prominently rubified colors in the 5YR and 7.5YR hues (e.g. Zones 1, 2, 3, and 5 ), fragments of former Bt horizons, and in some instances fragments of $\mathrm{K}$ horizons or Bk horizons of advanced morphology. Where the fine-grained fragments of parent material soils were preserved intact, these deposits were non-effervescent, but where significant mixing with caliche during placement, runoff, or subsequent grading had occurred the deposits were typically very reactive with dilute hydrochloric acid. Zone 4 was clearly derived from a different source, which appeared to have been a (possibly late) Holocene alluvial deposit, given that it was not rubified (it exhibited 10YR hues) and strongly effervescent.

\section{The INTERFACE Deposit}

The deposit immediately on top of the in situ alluvium and beneath the clearly road related fills, identified as Zone 6 (Figure 5.5), exhibited a wide range of morphology and composition, and was not immediately assignable to one group or the other as it shared attributes of both. Like Zone 4, this deposit exhibited a 10YR hue, but was non-effervescent and contained prehistoric, historic, and modern cultural material. At the eastern end of the trench this deposit was clearly laminated and appeared to be runoff related, whereas closer to the cutbank/bridge it became more massive. Numerous burned sandstone rocks and pieces of lithic debitage were observed within Zone 6, as was a large piece of metal, presumably part of a farm implement. At first this deposit was thought to be a drape of late Holocene alluvium, but close inspection revealed inclusions of rounded earth fragments and subtle structures that were more consistent with a road-related fill.

\section{IN SITU AlLUVIUM}

The natural deposits beneath the road-related sediments consisted of Zones 7, 8, 9, and 10, and appear to be part of a late Pleistocene alluvial fill, the tread of which is clearly somewhat cumulic. The profile appeared to be an Ak-ABk-Bk1-Bk2 profile with the top three horizons exhibiting minor accumulation of filamentous calcium carbonate, whereas the $\mathrm{Bk} 2$ horizon, only minimally exposed in the eastern end of the trench, exhibited a well-developed Stage II calcic horizon.

Zone 7 is a buried A horizon within which prehistoric cultural material was encapsulated, and this soil was clearly more organic-rich near the stream, and less so away from it. This topsoil appeared to be thicker and presumably cumulic at the foot of the upland slope, but all of the cultural material in this portion of the profile was located at or very shallowly below the former ground surface. Therefore, if it was cumulic in this location, the period of aggradation predated prehistoric occupation. If one examines the stratigraphic position of the cultural material exposed in BHT 1 (Figure 5.5), it is also clear that this material becomes progressively buried toward the bridge. The period of cumulic deposition at the western end of BHT 1 is clearly opposite than at the eastern end, specifically during and/or following the period of occupation. There appeared to be subtle separation (roughly $5-10 \mathrm{~cm}$ ) of some of the cultural material toward the western end of BHT 1, but it was difficult to determine if the separation represented more than one occupational surface or was just a factor of the distribution of burned sandstone piles across the gradually sloping cultural surface. If there were truly two different occupations present, it was 
impossible to determine in the field how much time separated them.

The age assessment of the core of the terrace is based on the presence of a well-developed stage II calcic horizon that was barely exposed at the east end of BHT 1. The degree of development is considered to be consistent with the Pleistocene age, and nearly all of the soil above this horizon was non-effervescent, which is also consistent with such an age. Given the fact that Zone 7 was so clearly cumulic during and following prehistoric occupation, considered together with a change in the thickness of the A horizon $13 \mathrm{~m}$ away from the western end of the trench, it is possible that there may be two alluvial fills present. However, the backhoe trench was too shallow to clearly demonstrate it. Alternatively, and more likely, it is possible that this is largely a Pleistocene alluvial deposit, the leading edge of which has received incremental deposition in the late Holocene, presumably in conjunction with the arrival of the channel near its present position.

\section{INTERPRETATIONS}

It is clear that the prehistoric cultural material at the west end of BHT 1 is shallowly buried and that the sedimentation may have occurred in a discrete enough period to separate different age occupations. The process would have been most effective at the cutbank and increasingly less effective to the east in proximity to the upland. The apparent age of the core of this terrace suggests that this surface may have been exposed for most or all of the Holocene. The occurrence of the cultural material in an A horizon makes bulk sediment dating ineffective. The best means of assessing the period of cumulic sedimentation is through direct radiocarbon dating of culturally associated charcoal.

Four radiocarbon dates were obtained from carbonized wood samples at the site. Two samples were taken from the disturbed interface deposit (Zone 6 ) in TUs 1 and 2, which returned dates of $230 \pm 40$ B.P. and $270 \pm 40$ B.P. Two additional samples were acquired from Feature 2 contexts in Zone 7, one from
TU 2 and another from TU 3. One sample returned a date of $200 \pm 40$ B.P. and the other was measured at $2,920 \pm 40$ B.P. The two dates obtained from the interface deposit are historic in age, and indicate a historic period deposition of the zone (although exactly when this deposition took place, or whether it was natural, is unclear). One date from Feature 2 is also historic in age, and is even slightly younger than the samples from the interface deposit. Most likely this is an intrusive root or other piece of organic material into the zone. The other date from Feature 2 is Late Archaic in age, which is much later than the Early/Middle Archaic represented by the Pandale point found in the same test unit (TU 2) at the same level (level 6). ${ }^{1}$

Presumably, the Pandale point and radiocarbon sample were recovered from a place where the stratigraphic compression is less significant than at the rear of the terrace and would be the location of the greatest separation of cultural components (Figures 5.5 and 5.6). If the Pandale point and the radiocarbon date accurately represent occupation of the site from the Early/Middle to Late Archaic, then this implies that there has been about $40 \mathrm{~cm}$ of sedimentation on the leading edge of this surface since roughly the middle Holocene.

In addition to the recovery of the Pandale point at site 41SS164, Horizon reported the discovery of a Fairland-like point by the landowner on the ground surface at the rear of the $T_{2}$ surface. Specifically it was found south of the county road at the time of the Horizon investigations (Reign Clark, personal communication, 2006). This point implies a presence of a Transitional Archaic occupation at the site, but no further evidence was located during the testing investigations to further support the presence of an occupation during that time period.

\section{Cultural Components}

As mentioned above, the interface deposit between the road-related deposits and the in situ alluvium deposits was determined to be some sort of mixed fill, possibly brought in sometime in the historic

\footnotetext{
${ }^{1}$ See Chapter 6 for a more detailed discussion of the Pandale point and associated dates.
} 
era, which contained both prehistoric and historic cultural material, as well as numerous gravels. Thus, only one intact cultural component, Analytical Unit 1 (AU 1), was documented during the testing excavations. The cultural component in the interface deposit is considered to be disturbed, and is only briefly described here.

For AU 1, the difficulty in distinguishing any separate occupation surfaces and the lone subsurface temporally diagnostic artifact make dividing the cultural material into more discrete occupation surfaces unfeasible. However, as a general observation, AU 1 can be correlated to the natural stratigraphy at the site (entirely located in Zone 7), which slopes downward to the west. This makes statements about elevation ranges somewhat complicated; therefore, the following descriptions generally will give a high and low elevation of features where appropriate. The summary of AU 1 includes descriptions of its temporal association, stratigraphy, horizontal extent, and associated features and artifacts.

\section{Disturbed Cultural Component}

Evidence of the disturbed cultural (component contained within the interface deposit) was found in BHT 1, in an ACk horizon of dark grayish-brown loam (10YR 4.5/3; Zone 6). This deposit is located just above Zone 7 , the intact cultural component (AU 1) of the site. At first this deposit was thought to contain another intact cultural component of a different, perhaps younger, time period, and TUs 1 and 2 were initiated just above this layer to excavate a portion of this component by hand. Later, it was determined that this deposit was not intact, but rather a fill layer from another area, which just happens to contain cultural material. To substantiate this conclusion, the soil was observed to contain rounded earth fragments and subtle structures, a non-effervescent matrix, various rounded gravels mixed with the burned sandstone, very small quantities of lithic debris, and both prehistoric and historic artifacts. These attributes would be very rare, if not impossible, in an intact cultural deposit.

\section{TIME PERIod}

The time at which this deposit was laid down is currently unknown, but it would likely be sometime prior to the construction of the steel truss bridge currently occupying the terrace. Unfortunately, traditional dating methods such as temporally diagnostic artifacts and carbonized organic material cannot be accurately used, as any of this material is likely to have been imported to this location from elsewhere. However, two charcoal samples were collected from this deposit, and were sent for analysis. The samples from the disturbed cultural component were determined to be live oak with calibrated dates of $230 \pm 40$ B.P. and $270 \pm 40$ в.P. Unfortunately, the live oak and mesquite samples from the lower deposit returned calibrated dates of $200 \pm 40$ B.P. and $2,900 \pm 40$ B.P., respectively. With such results, no clear indication as to when the disturbed cultural zone was laid down or its interaction with the lower deposit can be interpreted.

\section{Stratigraphic Position and Vertical Limits}

The vertical extent of this disturbed cultural component is best observable in the profile of BHT 1. As seen in Figure 5.5, the western end of the deposit is the thickest, at about $40 \mathrm{~cm}$ thick, between $98.09 \mathrm{~m}$ ( $\sim 60 \mathrm{cmbs})$ and $97.69 \mathrm{~m}(\sim 100 \mathrm{cmbs})$. The deposit gradually thins and slopes upward to the east, terminating in the backhoe trench about $20 \mathrm{~m}$ away at $98.44 \mathrm{~m}(\sim 25 \mathrm{cmbs})$. Figure $5.6^{2}$, a more detailed map of the cultural material seen in the south wall of BHT 1, shows the cultural material in this deposit as scattered throughout the level, with no observable pattern.

\section{HoRIZONTAL EXTENT}

The horizontal extent of this disturbed cultural component is not entirely known, but the zone appears to largely span the length of the site from east to west. From north to south, the deposit is seen in both trenches excavated in the roadway, but it is unknown

\footnotetext{
${ }^{2}$ In the process of making this map, a posthole was observed through Zones 6 and 7 at the westernmost edge of BHT 1. The posthole is adjacent to Zone 5, and the two may be associated. A very large common nail and scraps of wood were observed in the posthole.
} 


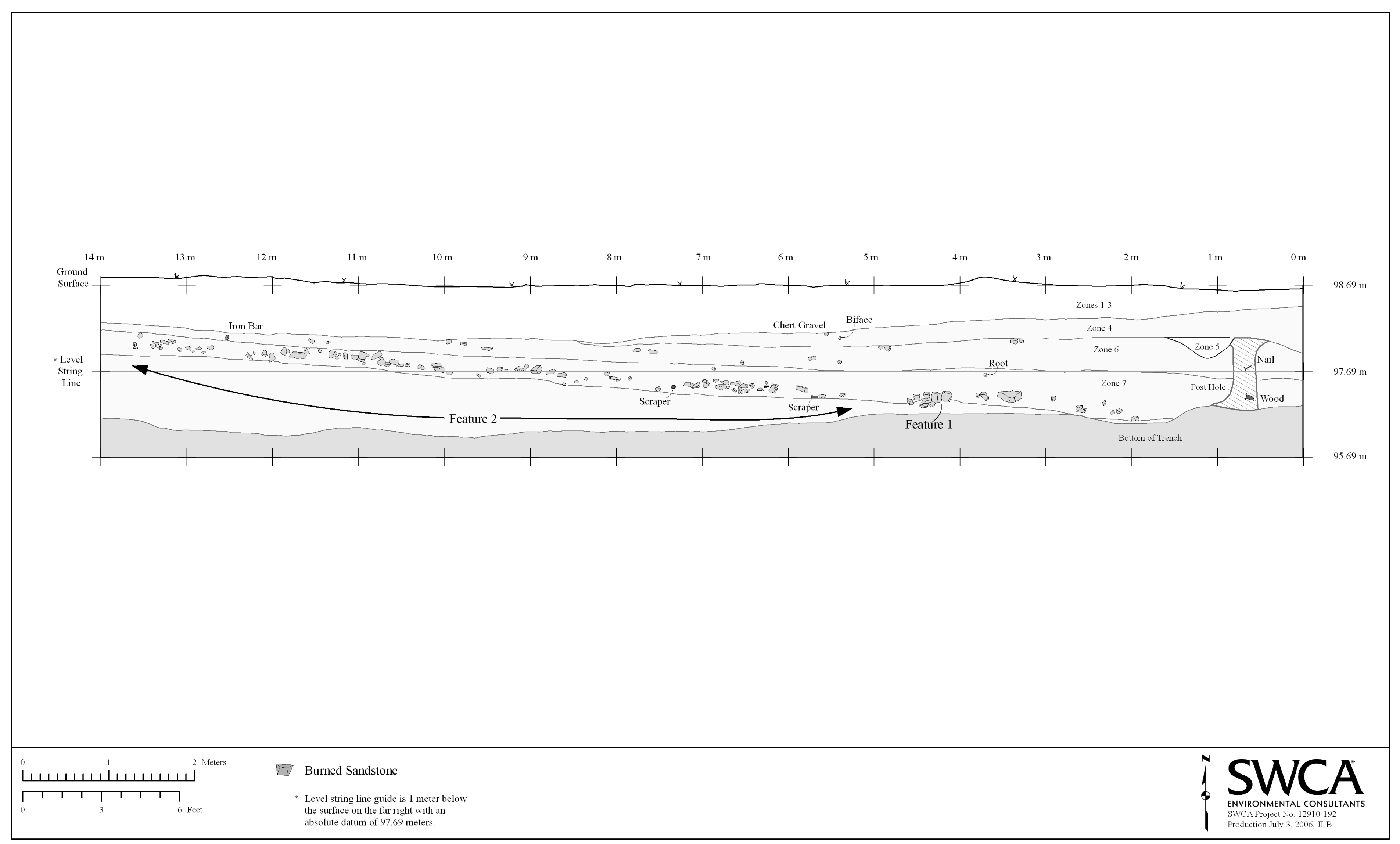

Figure 5.6. Profile of the south wall of BHT 1 with details of the cultural components. 
Table 5.3. Materials Recovered from Test Units by Context

\begin{tabular}{|c|c|c|c|c|c|c|}
\hline \multirow[b]{2}{*}{ Artifact Type } & \multicolumn{2}{|c|}{ Road-Related Deposits } & \multicolumn{2}{|c|}{ Interface Deposit } & \multicolumn{2}{|c|}{ In Situ Alluvium } \\
\hline & Count & Density ${ }^{1}$ & Count & Density ${ }^{1}$ & Count & Density ${ }^{1}$ \\
\hline Historic Artifacts & 0 & 0.00 & $5^{3}$ & 3.23 & 0 & 0.00 \\
\hline Bifaces & $0^{2}$ & 0.00 & 3 & 1.94 & 4 & 2.67 \\
\hline Cores & 0 & 0.00 & 1 & 0.65 & $2^{4}$ & 1.33 \\
\hline Pandale Point & 0 & 0.00 & 0 & 0.00 & 1 & 0.67 \\
\hline Broken Flakes & 0 & 0.00 & 117 & 75.48 & 173 & 115.33 \\
\hline Proximal Flakes & 0 & 0.00 & 38 & 24.52 & 60 & 40.00 \\
\hline Complete Flakes & 0 & 0.00 & 54 & 34.84 & 68 & 45.33 \\
\hline Thermal Shatter & 0 & 0.00 & 12 & 7.74 & 5 & 3.33 \\
\hline Rock Shatter & 0 & 0.00 & 43 & 27.74 & 40 & 26.67 \\
\hline Informal Tools & 0 & 0.00 & 0 & 0.00 & $0^{5}$ & 0.00 \\
\hline Groundstone & 0 & 0.00 & 0 & 0.00 & 2 & 1.33 \\
\hline Snail Shell & 0 & 0.00 & 1 & 0.65 & 0 & 0.00 \\
\hline Bone & 0 & 0.00 & 0 & 0.00 & 14 & 9.33 \\
\hline Carbon Sample & 0 & 0.00 & 2 & 1.29 & 2 & 1.33 \\
\hline Soil Sample & 0 & 0.00 & 0 & 0.00 & 2 & 1.33 \\
\hline FCR Count & 0 & 0.00 & 356 & 229.68 & 1096 & 730.67 \\
\hline FCR Weight (kg) & 0 & 0.00 & 35.8 & 23.10 & 145.7 & 97.13 \\
\hline
\end{tabular}

${ }^{1}$ Density is the approximate number of items per cubic meter of excavation.

2 Biface recovered from BHT 1 profile not included above.

${ }^{3}$ Two artifacts recovered from BHT 1 profile are not included above.

${ }^{4}$ One core recovered from BHT 1 not included above.

${ }_{5}$ Two informal flake tools recovered from BHT 1 not included above.

if this stratigraphic zone matches anything found in the backhoe trench excavated by Horizon outside of the ROW. It can at least be certain that the disturbed cultural zone extends across the ROW.

About $1.55 \mathrm{~m}^{3}$ of the disturbed cultural component was excavated by hand. The materials from the disturbed cultural component encountered in TUs 1 and 2 comprise over 276 pieces of debitage, lithic shatter, tools, and historic artifacts (Table 5.3; Appendix A). The burned sandstone was encountered in Levels 3 and 4 of TU 1, at base depths between 98.11-97.95 $\mathrm{m}$. In TU 2, burned sandstone was found in Levels 2 and 3 at base depths of $98.08-97.93 \mathrm{~m}$. No projectile points were recovered. The tools include three bifaces and a core, and the historic artifacts include two pieces of bottle glass, an iron bolt, a piece of transfer printed whiteware, and a piece of plastic. One Helicina shell fragment was also recovered.

\section{Analytical Unit 1}

Evidence of AU 1 was found in BHT 1, (contained within the in situ alluvium) in a $2 \mathrm{Akb}$ horizon of very dark grayish-brown loam (10YR 4/2; Zone 7). TUs 1,2 , and 3 were excavated to expose AU 1 in plan view along the backhoe trench. Additionally, the 50$\mathrm{x}-50$-cm column sample was initiated just above this component to determine its integrity at the eastern end of the site. A Pandale point found within this component dates the occupation to the Early/Middle Archaic period (8,800-4,000 B.P.). Although cultural material was observed at differing levels within the stratigraphic zone, the nature of the deposit made it difficult to divide this component further into upper and lower components, if they indeed exist. 


\section{TIME PERIOD}

AU 1 dates to the Early Archaic (8,800-6,000 B.P.) or Middle Archaic (6,000-4,000 B.P.) period, based on the presence of one dart point, a Pandale. The Pandale point is much more common in the Lower Pecos area, where a greater number of dates are available to establish its context. The distribution is somewhat limited in central Texas. Though no other Pandale points have been previously noted in San Saba County, a few (1-11) have been noted in nearby Gillespie County to the south, Coleman, Concho, and Runnells Counties to the northwest; and Williamson County to the southeast (Prewitt 1995:125). A slightly higher number (11-51) of Pandale points have been found in Hays County (Prewitt 1995:125).

A radiocarbon date was recovered from TU 2, level 6, at the same level as the Pandale point (97.69 m). However, the mesquite sample returned a date of $2,900 \pm 40$ B.P. (Late Archaic), far younger than the dates attributed to the Pandale. However, as described above and in Chapter 6, AU 1 shows evidence of limited stratigraphic separation and considerable compression of many centuries of deposits. This is the most likely explanation of two artifacts with different associated dates found together in the same unit level.

\section{Stratigraphic Position and Vertical Limits}

The vertical extent of AU 1 is best observable in the profile of BHT 1. As seen in Figure 5.5, the lower boundary of Zone 7 is variable and grades into Zones 8 and 9 at varying depths. AU 1 resides entirely within Zone 7, but the lower boundary for the zone is not necessarily the same as the cultural component. For example, in the area closest to Richland Springs Creek at the western side of the site and around Features 1 and 2, AU 1 and the lower boundary of Zone 7 correspond with each other. However, towards the eastern side of the site, Zone 7 increases in depth while the cultural material hovers close to the top of the zone. In fact, this difference between the limits of AU 1 and Zone 7 may be a sign of varying degrees of stratigraphic compression at the site (more towards the creek and less away from it, see
Natural Stratigraphy above). Here, AU 1 is defined as the vertical limits of the cultural material seen in Zone 7, which at times will correspond with the entirety of the zone, and other times will not. For a view of AU 1 and Zone 7 where they correspond, Figure 5.6 best depicts the vertical limits of the intact cultural deposit.

The component slopes downward from east to west, and also thickens in the same direction, from about $20 \mathrm{~cm}$ thick at the eastern end to $55 \mathrm{~cm}$ thick at the western end. The western end of the deposit is located between $97.69 \mathrm{~m}(\sim 100 \mathrm{cmbs})$ and 97.14 $\mathrm{m}(\sim 155 \mathrm{cmbs})$. At the eastern end, the deposit is located between $98.39 \mathrm{~m} \mathrm{(} \mathrm{30} \mathrm{cmbs)} \mathrm{and} 98.19 \mathrm{~m}$ ( $\sim 50 \mathrm{cmbs})$.

\section{HoRIZONTAL EXTENT}

The horizontal extent of AU 1 is not entirely known, but the component appears to largely span the length of the site from east to west $(26 \mathrm{~m})$. From north to south, the deposit is seen in both trenches excavated in the roadway, and it is likely this deposit matches the cultural zone found in the backhoe trench excavated by Horizon outside of the ROW. It is also highly likely the site extends into the proposed new ROW required for the bridge replacement north of the roadway, although this area has been truncated by steep gullies a few meters past the existing fence line. The portion of the site north of the fenceline/existing ROW is therefore very small and eroded.

\section{FEATURES}

AU 1 contains two primary features. Feature 1 was only visible in BHT 1 (Figure 5.6; Table 5.4) and was not excavated further during the testing project. Feature 2 is a long linear feature that was encountered in BHT 1 and TUs 1, 2, and 3 (Figure 5.6; Table 5.4).

\section{Feature 1 (Elevation of 97.50-97.31 m)}

Feature 1 is a small discrete cluster of burned sandstone about $50 \mathrm{~cm}$ wide that was observed in the southern profile of BHT 1. The feature does not 
Table 5.4. List of Features from 41SS164

\begin{tabular}{|c|c|c|c|l|}
\hline Feature & Context & Provenience & Elevation (m) & \multicolumn{1}{|c|}{ Description } \\
\hline 1 & AU 1 & BHT 1 (west) & 97.5 to 97.31 & $\begin{array}{l}\text { Fire-cracked sandstone concentration, 50 cm } \\
\text { wide, located approximately 4 m east of the } \\
\text { west end of BHT 1, in the south wall profile } \\
\text { (not excavated) }\end{array}$ \\
\hline 2 & AU 1 & $\begin{array}{c}\text { TUs 1, 2, and 3 } \\
\text { and BHT 1 }\end{array}$ & $\begin{array}{l}98.00-97.40 \text { (BHT pro- } \\
\text { file); 97.9 to 97.6 (TUs) }\end{array}$ & $\begin{array}{l}\text { A layer of fire-cracked sandstone of at least 8.5 } \\
\text { m in length mixed with a high concentration of } \\
\text { debitage }\end{array}$ \\
\hline
\end{tabular}

appear to be basin-shaped, but instead appears to be an asymmetrical stack of rocks in the profile (Figure 5.7). The sandstone rocks were observed to be generally around $8-15 \mathrm{~cm}$ in diameter and angular in shape. The stack is four-stones thick in some places, and, although several pieces of burned sandstone are located within $25 \mathrm{~cm}$ of the feature, it appears to be a tight cluster distinctly separate from other rocks. Since it was not further investigated, however, the exact shape of the feature is unknown. Although Feature 1 may be a hearth or other cooking feature, the observed portion in the southern wall of BHT 1 does not show the typical basin shape or dark organic matrix of an intact hearth. Thus, Feature 1 may equally be part of a larger pile similar to Feature 2 . The nature of Feature 1 can only be guessed at given the current information.

Feature 2 (Elevation of $98.00-$

\section{$97.40 \mathrm{~m})$}

Feature 2 was observed in both the north and south walls of BHT 1 as well as portions of BHT 2. Feature 2 is a long linear fire-cracked rock zone in a sheet-like pattern on a sloping surface. It was encountered in TUs 1, 2, and 3, extending across all three units from east to west (Table 5.4; Figures 5.8 and 5.9). The feature was seen uninterrupted from north to south in each unit and was also visible in both wall profiles of BHT 1 on either side of all three units. On the northern side of the backhoe trench, the east-west limits of the feature apparently extended beyond TU 3 to the east, though it remained unexcavated, and extended beyond TU 2 to the west and into TU 1, with some dissipation on the western end of the exposure at that point. Feature 2 was seen in BHT 1 extending a total distance of $8.5 \mathrm{~m}$ eastwest. Therefore, the exact total extent of the feature is unknown, but it is at least $8.5 \mathrm{~m}$ wide and extends under the roadway to the north of the excavation units for an unknown distance. The vertical extent of the feature within the hand-excavated units was from 97.9-97.6 $\mathrm{m}$ in elevation (Table 5.4), and approximately $98.00-97.40 \mathrm{~m}$ across the BHT 1 profile. The $20 \mathrm{~cm}$ lens of burned sandstone did not appear internally stratified. If the feature was accumulated in more than one event, it was not discernable in the test excavations or the BHT 1 profile.

The excavated portion of the feature comprised 145.7 $\mathrm{kg}$ of burned sandstone with 1 percent $(\mathrm{n}=11)$ greater

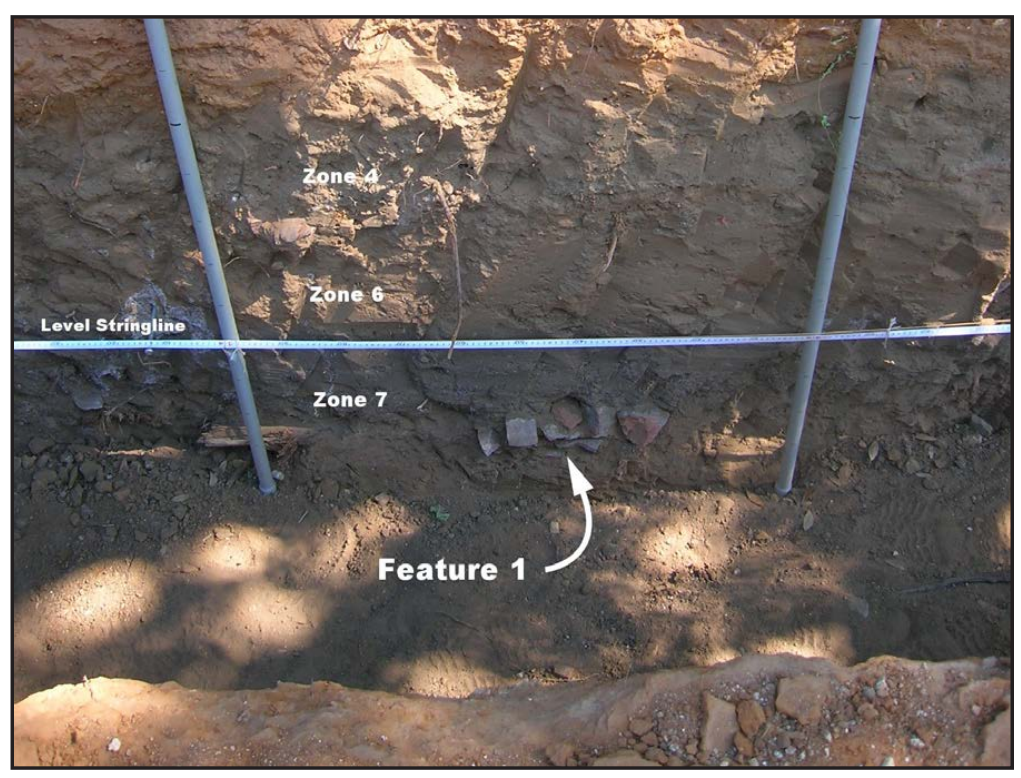

Figure 5.7. Photo of Feature 1 at the base of BHT 1, south wall, facing south. 
5-16 Chapter 5

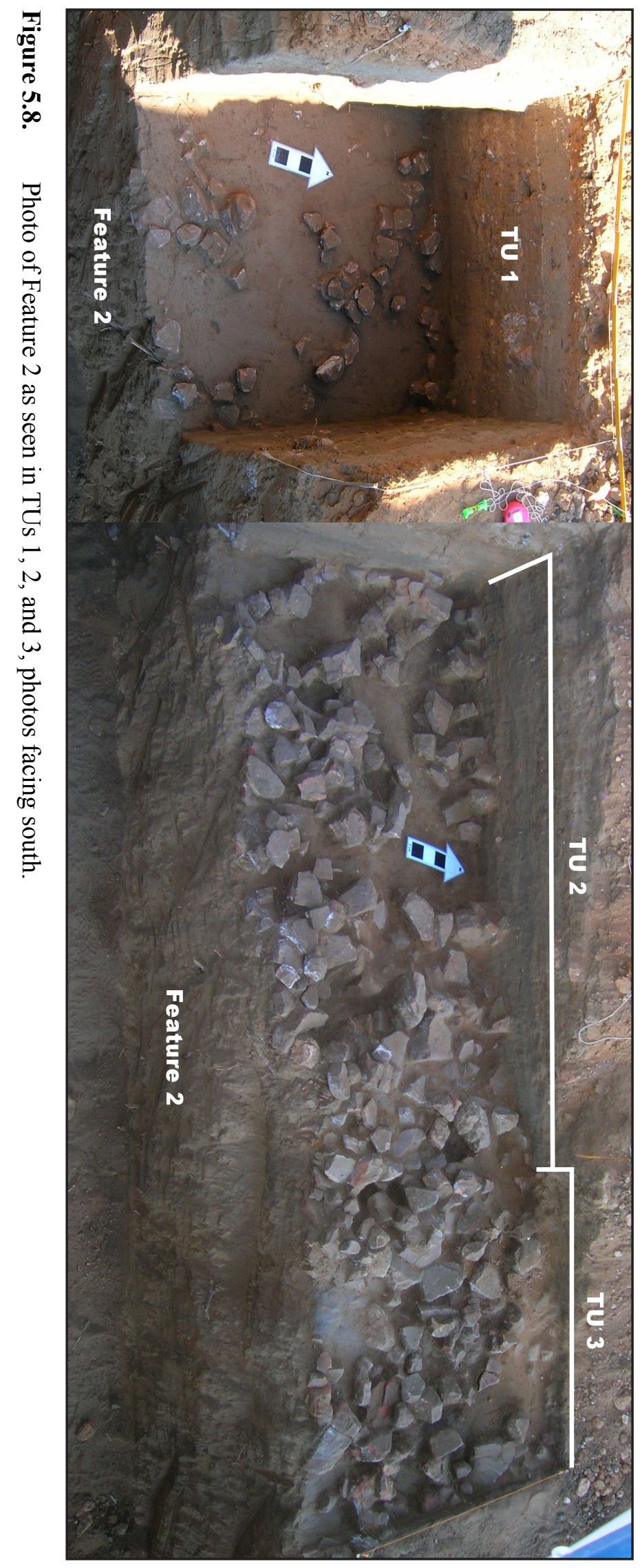




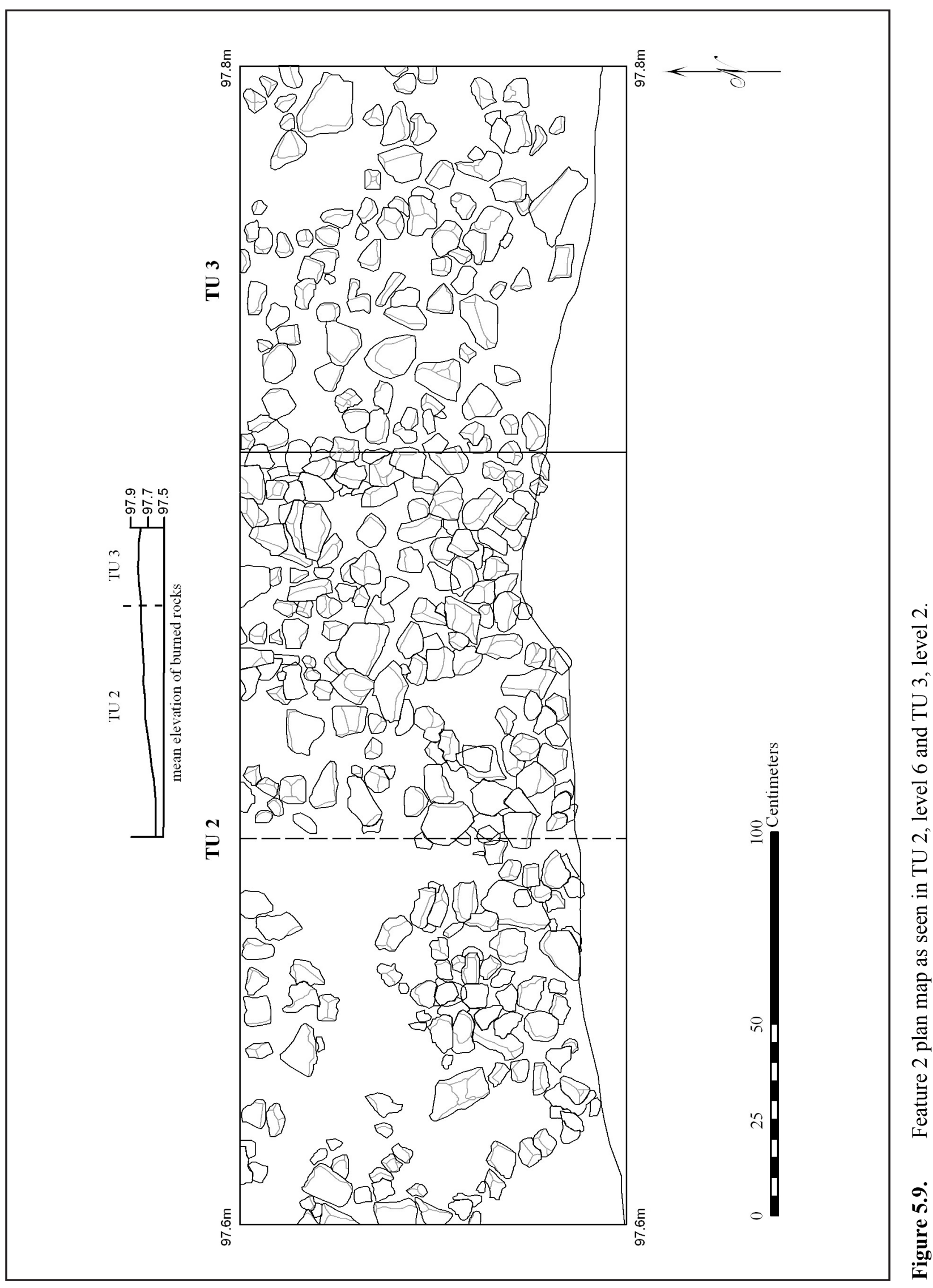


Table 5.5. AU 1 Recovery Summary

\begin{tabular}{|c|c|c|c|c|c|c|c|c|c|c|c|}
\hline 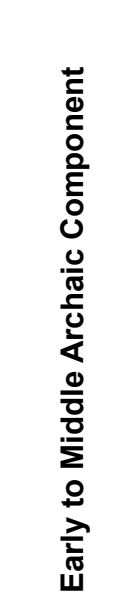 & 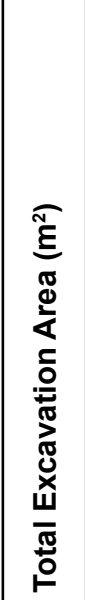 & 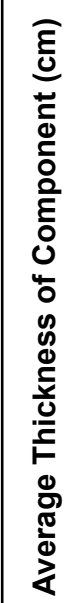 & 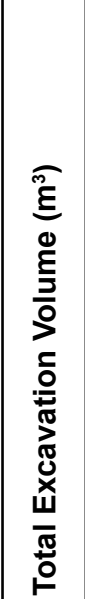 & 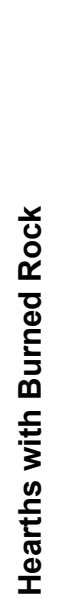 & 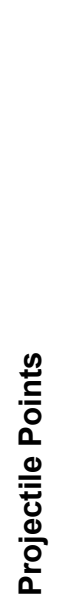 & 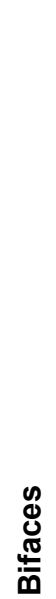 & ڤँ & $\begin{array}{l}\stackrel{0}{0} \\
\text { ஸे }\end{array}$ & 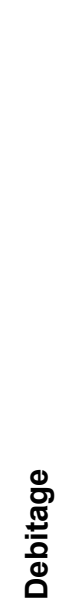 & 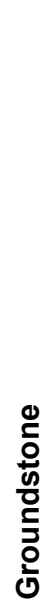 & 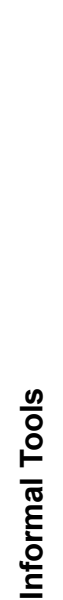 \\
\hline 41SS164 & 4.25 & 37.5 & 1.25 & 2 & 1 & 4 & 3 & 14 & 351 & 2 & 2 \\
\hline
\end{tabular}

than $15 \mathrm{~cm}$ in maximum dimension, 12.5 percent $(\mathrm{n}=137) 10-15 \mathrm{~cm}, 45.4$ percent $(\mathrm{n}=498) 5-10 \mathrm{~cm}$, and 41 percent $(\mathrm{n}=450) 0-5 \mathrm{~cm}$, the smallest sized cobbles (Table 5.3). The fire-cracked rocks making up the feature were not evenly distributed but varied in density across the test units (Figure 5.9). The highest density was encountered in TU 2 , on the order of 866 per cubic meter. The rocks were tightly packed with little fine matrix amongst them. The fine matrix was similar to the surrounding soil deposits and had no staining, ash, or charcoal flecking. No central pit feature or other distinct pattern was noted in the sheet midden.

Further indication of the likelihood that the feature is representative of a sheet midden is the high density of debitage mixed in with the lens of burned sandstone cobbles. The densities of debitage are similarly highest in TU 2 (Appendix A).

In all, about $1.75 \mathrm{~m}^{3}$ of the in situ alluvium was excavated by hand, of which $1.25 \mathrm{~m}^{3}$ was located in AU 1. The materials from AU 1 encountered in TUs 1-4 and the column sample comprise over 351 pieces of debitage, tools, bone, groundstone, and special samples. Over 1,096 individual fire-cracked rocks were also recorded (Table 5.5; Appendix A). One projectile point, a Pandale, was recovered. The tools include four bifaces and two cores, one of which is a possible scraper. The groundstone included one mano and one metate, and the bone was all from a bison bison. Two radiocarbon samples and two soil samples were collected from AU 1. In addition, one core and two informal tools were recovered from the wall of BHT 1. 


\section{Chapter 6}

\section{Recovered Materials}

\section{Michael R. Chavez}

\section{Material Recovered}

The materials recovered from site 41SS164 include eight bifaces, 610 pieces of debitage, two informal tools, four cores, two pieces of groundstone, one projectile point, and 14 bone fragments; in addition 1,452 pieces of fire-cracked rock were recorded and seven historic artifacts were recorded, two of which were collected (Table 6.1). The primary intact cultural deposit and highest artifact density was seen in association with Feature 2, which was profiled in BHT 1 from $98.0 \mathrm{~m}$ at the easternmost end to $97.4 \mathrm{~m}$ at the westernmost end (see Table 5.4). Table 6.2 profiles the artifact recovery by excavation unit and column sample, and shows the connection between the natural stratigraphy (Zones 1-10) and cultural components (disturbed cultural component and AU 1). Feature 2 is identified as a drape of fire-cracked rock believed to date to the Early or Middle Archaic.

\section{Historic ARtifaCtS}

In all, seven historic artifacts were observed in the disturbed cultural component, but only two were collected for analysis in the laboratory. Of the observed artifacts, three were metal, two were glass shards, one was a piece of plastic, and the last was a historic whiteware sherd. The three metal artifacts consisted of a long iron bar with a hole in one end (BHT 1 at $98.1 \mathrm{~m}$ ), the top of a hexagonal bolt (TU 1 at $98.2 \mathrm{~m}$ ), and a large iron nail (in a posthole at $97.7 \mathrm{~m}$ in BHT 1). Of the two glass shard artifacts, one clear fragment was discarded in the field (TU 1 at $98.27 \mathrm{~m}$ ), and the other amber glass fragment was collected (TU 2 at approximately 98.20 $\mathrm{m})$. The piece of plastic was found in TU 1 at 98.17 $\mathrm{m}$. Although all historic, these artifacts did not retain sufficient traits to date accurately.

However, the last historic artifact, the piece of whiteware (Lot TU 2 at approximately $98.20 \mathrm{~m}$ ), can be dated. The transfer printed whiteware fragment is pink/red in color and made by using the bat process (as evidenced by stippled dots), but the pattern was too small to determine the style, other than a floral design (Figure 6.1). However, based on the popularity of that color, a temporal association can be assigned. Based on information from Esary (1982), McCorvie (1987), Miller (1987), and Sonderman (1979), the pink/red transfer printed whiteware was most popular from 1829-1839, with a production range of 1829-1850.

\section{Dart Points}

One complete Pandale dart point (Lot 18) was excavated from TU 2, level 6, between 97.6 and $97.7 \mathrm{~m}$ in association with Feature 2 (Figure 6.2). The specimen is made of a white $(2.5 \mathrm{Y} 8 / 1)$ fine-grained chert that measures $48.53-\mathrm{x}-18.86 \mathrm{~mm}$ with a thickness of 7.55 $\mathrm{mm}$. The point exhibits alternate beveling along the base (typical of this type) that continues along the lateral edge of the point to wards the tip (atypical). A standard Pandale dart point displays opposite beveling of the stem and body to create a "peculiar corkscrew twist" (Turner and Hester 2002:168). Although this

Table 6.1. Material Recovered or Recorded from 41SS164 Testing

\begin{tabular}{|l|l|}
\hline Artifact Type & Total \\
\hline Biface & 8 \\
\hline Core & 4 \\
\hline Debitage & 610 \\
\hline Flake Tool (informal) & 2 \\
\hline Groundstone & 2 \\
\hline Projectile Point & 1 \\
\hline FCR & 1452 \\
\hline Faunal Remains & 14 \\
\hline Historic Artifacts & 7 \\
\hline Artifact Total & $\mathbf{2 1 0 0}$ \\
\hline
\end{tabular}




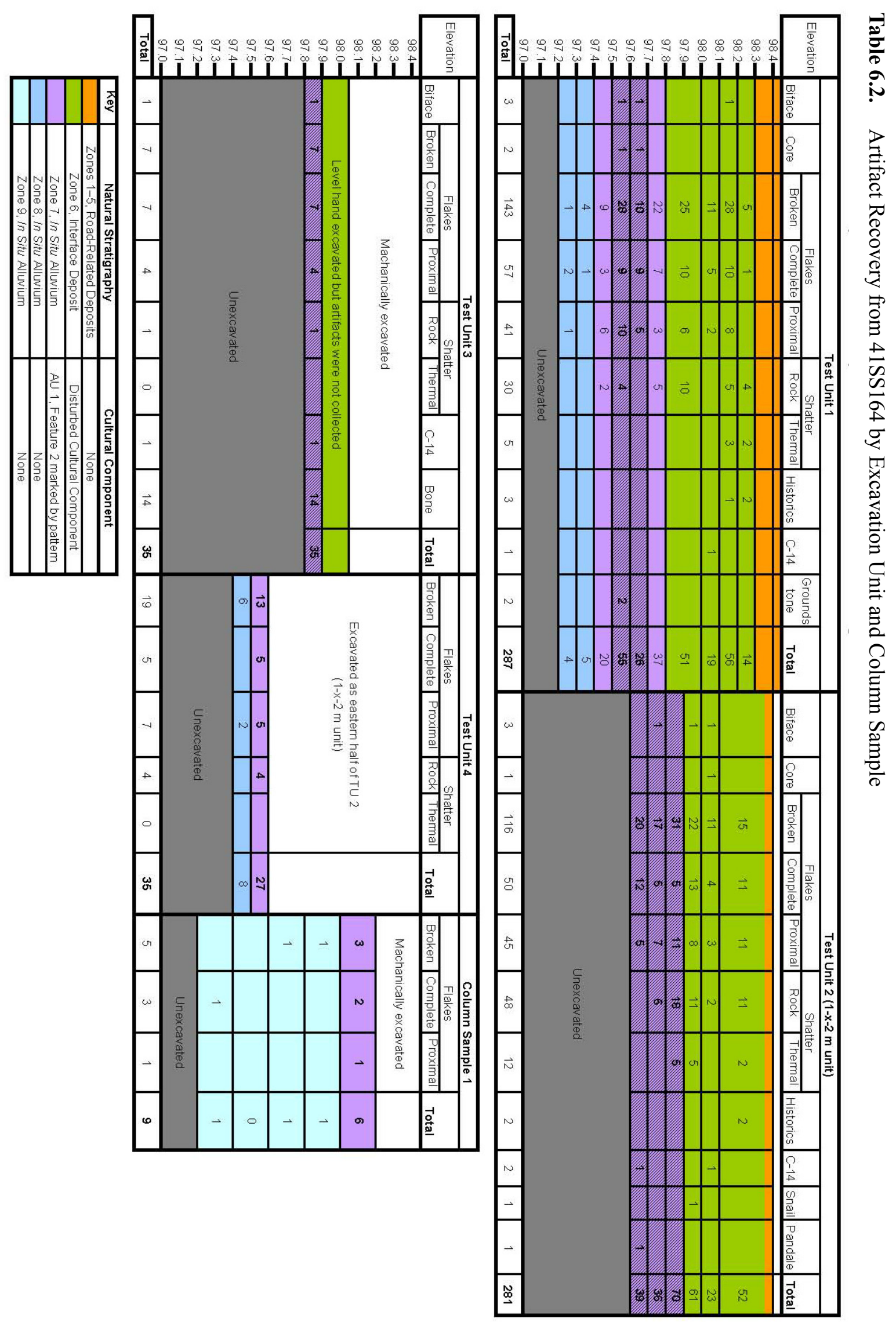




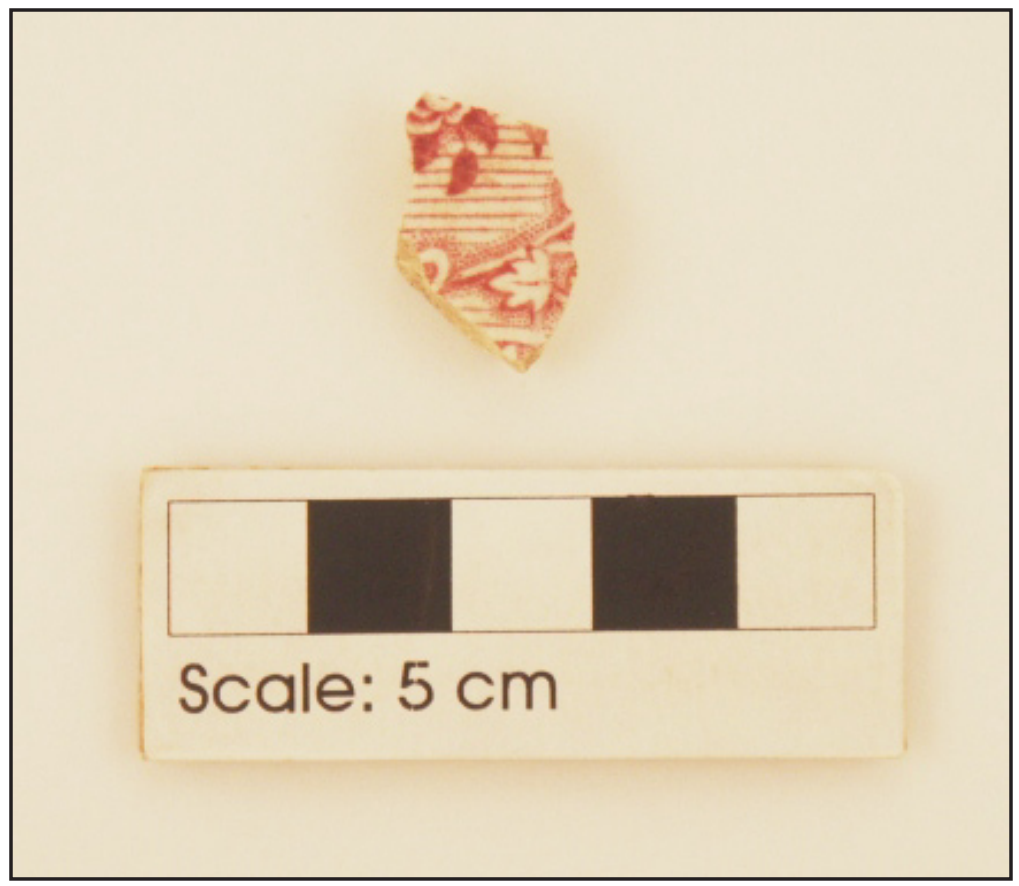

Figure 6.1. Whiteware fragment (Lot 2) from site 41SS164.

(Shafer 1986). A radiocarbon date from Baker Cave (Hester 1983:104) obtained just below a distinctive Pandale occupation and garbage pit is 4,690 140 B.P. (uncorrected). Hester (1989:59) also notes radiocarbon assays for Pandale points from several Lower Pecos sites, falling in the 4,700-4,100 B.P. timeframe.

A Fairland dart point was encountered on the ground surface during the Horizon survey investigations. Similar to Edgewood and Ellis points, it has a wide base with a distinct deep basal concavity (Turner and Hester 2002:117). Fairland points are known to occur in moderate quantities at sites in Gillespie, Llano, Burnett, Travis, Bell, and Williamson Counties, as well as many others in and around central Texas (Prewitt 1995:104). Though these points are well known in central Texas, Fairland points have also been found in south Texas and the lateral body edge to the beveled stem, the worked edges appear to have terminated upon encountering an irregular granularity near the tip. This has created only a slight twist on this specimen which is much less than the corkscrew twist seen on other specimens.

Though typical of the Lower Pecos area, Pandale points are occasionally found at sites in the Edwards Plateau and central Texas (Decker et al. 2000; Hester 1971; Prewitt 1995). Edwards Plateau Pandale points were recovered from possible Early/Middle Archaic components at 41CM111 in Comal County (Mahoney et al. 2003:40, Table 7-5) and at Panther Springs Creek in Bexar County (Black and McGraw 1985:120). Northern central Texas Pandale points were found at site $41 \mathrm{CN} 155$ in Coleman County and site 41RN119 in Runnels County prior to the construction of the O. H. Ivie Reservoir (41CN155 and 41RN119 Site Forms). In the Lower Pecos, Pandale points are placed in the Middle Archaic period

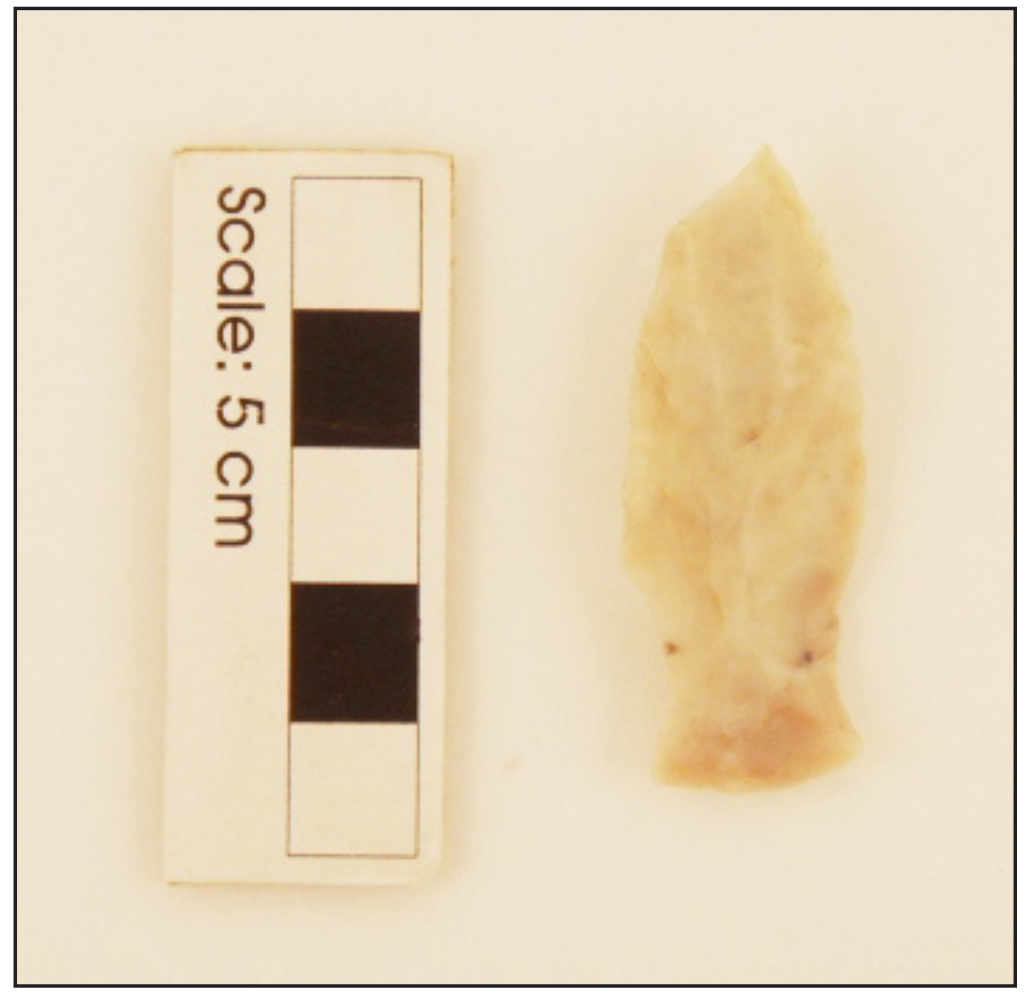

Figure 6.2. $\quad$ Pandale projectile point (Lot 18) from site $41 \mathrm{SS} 164$. 
Lower Pecos (Turner and Hester 2002:117). Fairland points are generally dated to the Transitional Archaic period (300 B.C.-A.D. 700), though Collins (2004: Figure 3.9a) links the Fairland points (along with Ensor and Frio points) to the Late Archaic, ca. $1,300-1,600$ B.P. (A.D. $350-650$ ).

\section{BIFACES}

A total of eight bifacial tools was found during the 41SS164 testing project. One biface was encountered in the uppermost roadway fill context, three were collected from the disturbed interface deposit, and four were encountered in the intact cultural deposits. None of the bifaces are complete specimens with the majority consisting of marginal fragments $(n=2)$ or indeterminate fragments $(n=3)$. Two of the specimens are the pointed distal fragments of either projectile points or large bifaces while the remaining specimen is the medial fragment of a possible projectile point (Figure 6.3).

The marginal fragments were recovered in association with Feature 2 in TUs 1 and 2. Each of the marginal fragments are extremely small, making it impossible to determine the parent tool type. Two of the three indeterminate biface fragments were recovered in TUs 1 and 2 in the disturbed interface deposit. One is an extremely small fragment while the other is a middle to late stage biface fragment that displaying evidence of thermal alteration with a slightly reddened color. The remaining indeterminate fragment was found in association with Feature 2 along with the two marginal fragments.

The biface recovered from the fill context is one of the distal fragments. The specimen is made from a pale yellow (2.5Y 7/3) fine-grained chert and appears to be the bifacially worked distal end of a large finely worked biface (or proximal end of a lanceolate shaped biface; [Figure 6.3, Lot 1]). The remaining distal bifacial fragment was recovered in level 8 of TU 1 between elevations of 97.6 and $97.5 \mathrm{~m}$. The specimen is made from a dark gray $(2.5 \mathrm{Y} 4 / 1)$ finegrained chert and appears to be beveled along both lateral edges of one facet (Figure 6.3, Lot 25). The size of the fragment lends to the possibility of it being the distal tip of either a projectile point or a formal biface. The medial fragment was recovered in TU 2 within the disturbed interface deposit. The specimen is a small grayish-brown (10YR 5/2) bifacially worked medial fragment of a probable projectile point (Figure 6.3, Lot 8).

\section{CORES}

The four cores recovered during the 41SS164 testing project consist mostly of small specimens that are either exhausted or could be labeled as tested cobbles. However, one of the specimens is a unidirectional core (Figure 6.4, Lot 25). It was recovered in level 8 of TU 1 between elevations of 97.6 and $97.5 \mathrm{~m}$ in association with Feature 2. The specimen is a shallow conical shape with a flat prepared surface. The lateral edges exhibit possible platform preparation with unidirectional hits cumulating at the end of the conical shape. The core's dimensions are 87.61-x$70.83 \mathrm{~mm}$ with a thickness of $39.22 \mathrm{~mm}$. A total of 20 negative flake scars are on the core with 13 of the scars being unidirectional hits along the conical portion of the core. No cortex or evidence of heat treatment is present on the specimen. Of the remain-

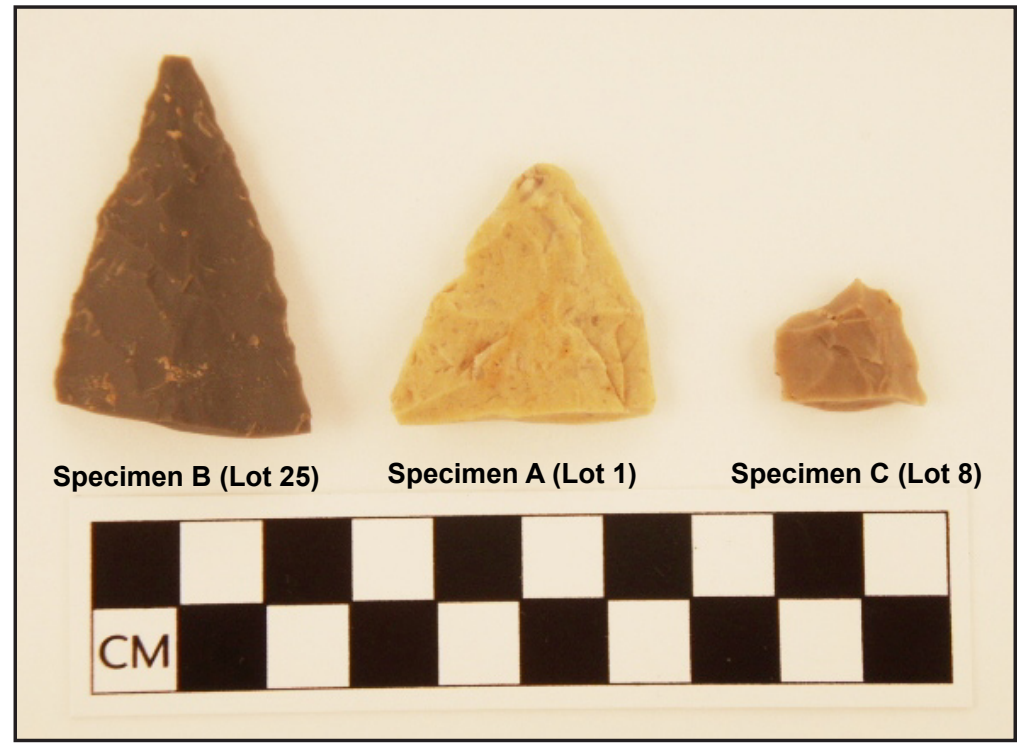

Figure 6.3. Distal and medial biface fragments from site $41 \mathrm{SS} 164$. 


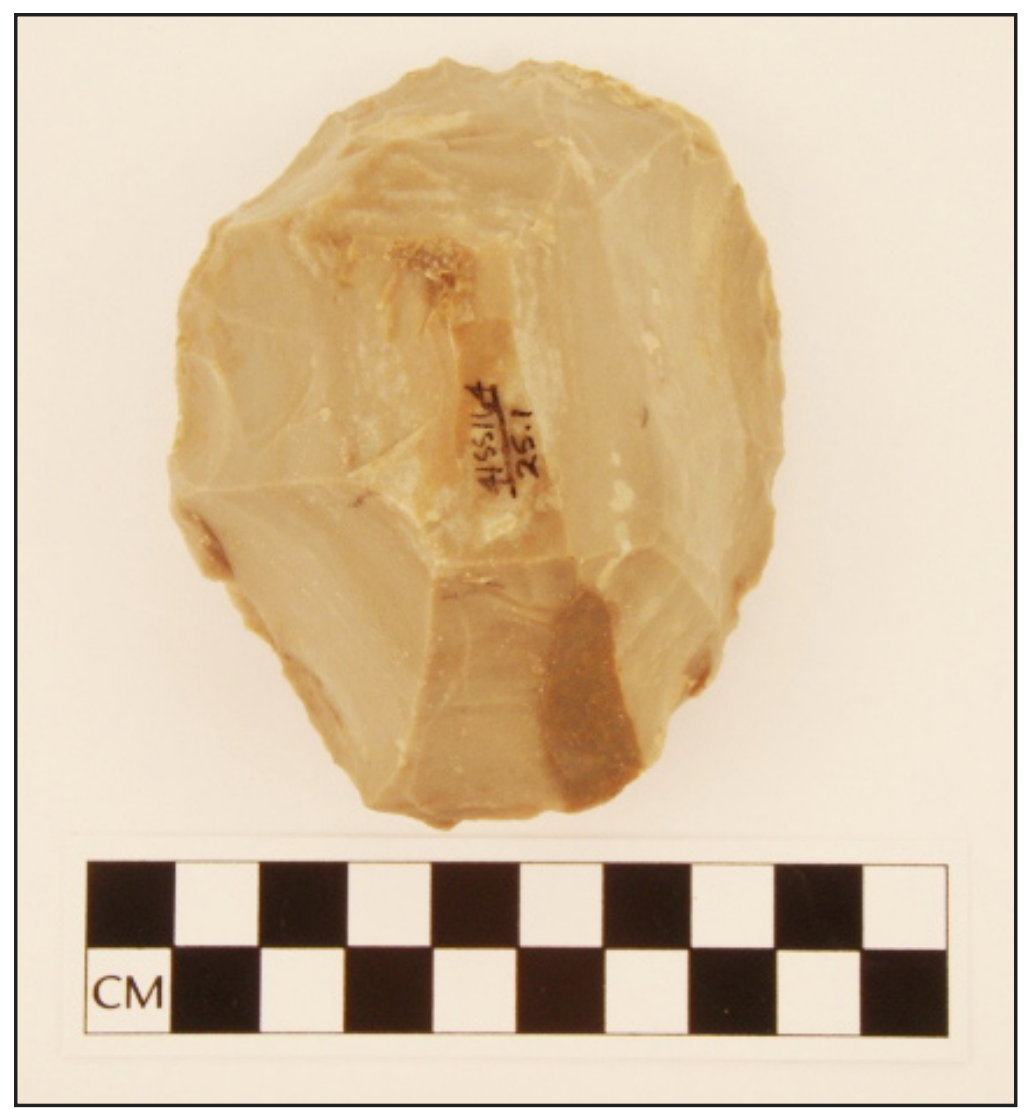

Figure 6.4. Unidirectional core (Lot 25.1) from site $41 \mathrm{SS} 164$.

ing cores, two were found in association with Feature 2 from TU 1 and from the wall of the BHT 1 while the remaining core was recovered in the disturbed interface deposits in TU 2.

\section{OTHER LITHIC TOOLS}

Two informal retouched flakes were recovered from the wall in BHT 1 in the intact cultural zone. Both flakes are relatively the same size (82.94-x-55.95x-22.67 mm; 86.51-x-62.27-x $18.08 \mathrm{~mm}$ ) with retouched flaking along the left lateral margins. The flakes both exhibit unifacial retouch flaking with one worked towards the dorsal surface and the other towards the ventral surface. The smaller of the two retouched flakes exhibits less than 25 percent cortex on the dorsal surface as well as evidence of heat treatment with a slight reddened color. Although both exhibit retouched flaking, there does not appear to be any evidence of utilization on the retouched lateral edges.

\section{GROUNDSTONE}

Two sandstone groundstone fragments were encountered next to each other in the prehistoric site deposits of the intact cultural zone in TU 1 between the elevations of 97.6 and $97.5 \mathrm{~m}$ in association with Feature 2. The specimens consist of the corner fragment of a metate (Lot 15) and the medial fragment of a mano (Lot 18) (Figure 6.5). The metate fragment has two smooth, flat, polished surfaces. The corner edge is rounded with no indication of usage after fragmentation. The mano fragment appears to consist of the majority of the medial segment of the entire specimen with both end portions missing. The specimen exhibits convex smoothing on alternating surfaces with one surface exhibiting greater utilization. Although two ends are missing from the medial fragment, an overall oval shape can be inferred from the remaining portion of the specimen.

\section{FAUNAL REMAINS}

The faunal assemblage consists of one fragmented specimen weighing a total of $13 \mathrm{~g}$ recovered from TU 3, Level 2. This specimen is the second phalanx of a Bison bison that has been broken into roughly 14 pieces during excavations. The bone is fairly well preserved, with minimal weathering in the form of cracking or fragmentation and no evidence of burning. The material is associated with Feature 2, found in TU 3 at an elevation of $97.9-97.8 \mathrm{~m}$.

\section{SPECIAL SAMPLES}

Six special samples were collected during testing of 41SS164, consisting of four charcoal samples and two soil samples, all of which were submitted for analysis (Appendices B and C). The four charcoal samples were split in half with each sample submitted for both macrobotanical analysis and radiocarbon dating. Two of the charcoal samples were collected from TU 2, level 2 near the burned sandstone in the 


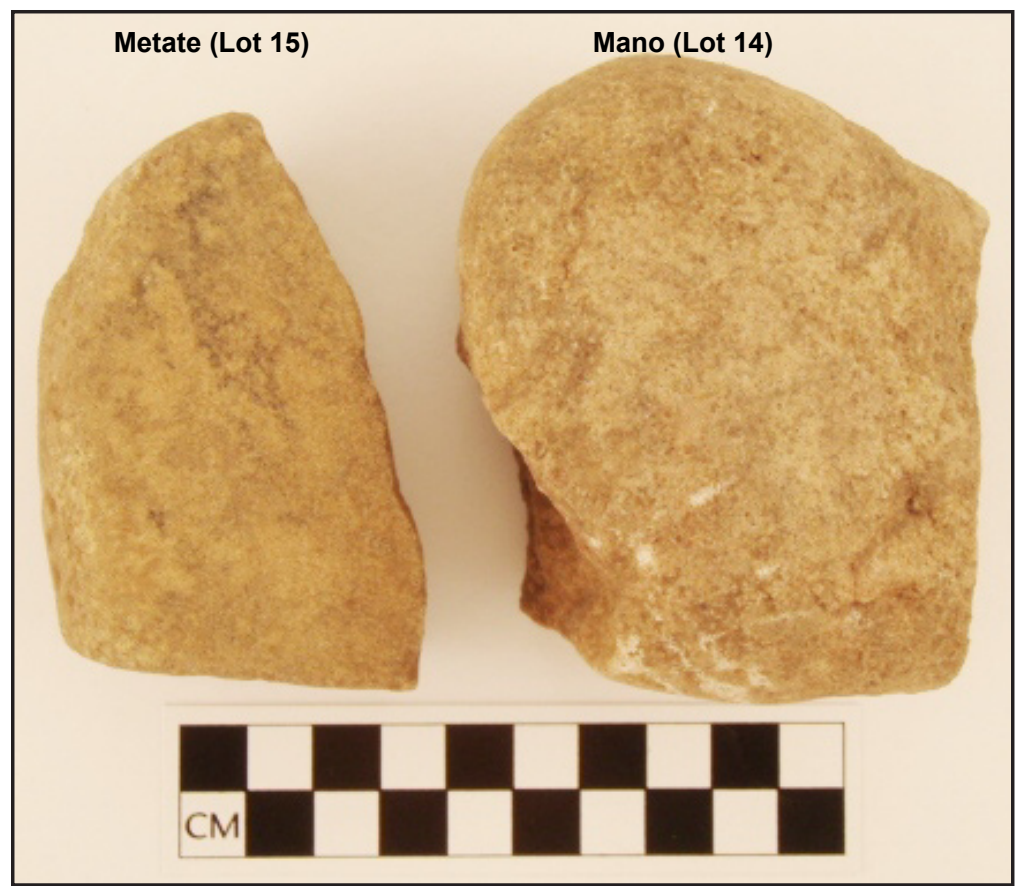

Figure 6.5. Groundstone fragments from site 41SS164. the soil prior to excavation (e.g., roots, and rootlets) or made their way into archeological units during excavation (e.g., leaves) while carbonized flora tends to indicate ancient origins. The carbonized material consisted of live oak (Quercus fusiformis), mesquite (Prosopis glandulosa), and two fragments of wood charcoal from a white group oak. Oaks from this group that are common to the project area consist of Post oak (Quercus stellata), Bur oak (Q. macrocarpa), and Bigelow's oak (Q. sinuata var. breviloba), which grows in rockier areas (Diggs et al. 1999; Turner et al. 2003). The uncarbonized material consisted of modern roots/rootlets, live oak leaves, legume leaves, and seeds of weedy taxa associated with disturbed areas such as roadsides. The live oak and legume leaves in the uncarbonized flora, which were also recovered from the carbonized flora, indicate the continuity of some common tree species in the Richland Creek area during the Holocene.

\section{LITHIC DEBITAGE}

\section{Categories and Methods}

The 41SS164 testing project recovered 610 pieces of lithic debitage. A total of 264 pieces of debitage were encountered in the disturbed interface deposit, and 300 pieces from the intact cultural deposits in association with Feature 2 with an additional 46 pieces from below the feature deposits in TUs 1, 4, and outside in the feature in CS 1 (Table 6.2).

Since the debitage was recovered from the disturbed interface deposit and within the compacted intact cultural deposit, the analysis of the debitage was kept to a minimum. Therefore, the analysis of the debitage was completed to explore general lithic reduction strategies and vertical displacement of artifacts at site 41SS164. To collect the data needed to address such issues, the debitage from the site was sorted and quantified into five categories based on individual specimen attributes. The categories were 
derived from a combination of methods outlined by Andrefsky (1998) and Hiscock (2002). These categories consisted of complete flakes, proximal flakes, broken flakes, rock shatter, and flaking/thermal shatter (Table 6.3).

Table 6.3. Flakes Recovered at 41SS164 by Category

\begin{tabular}{|l|c|}
\hline Flake Categories & Total \\
\hline Broken Flakes & 290 \\
\hline Complete Flakes & 122 \\
\hline Rock Shatter & 83 \\
\hline Proximal Flakes & 98 \\
\hline Thermal Shatter & 17 \\
\hline Flake Total & $\mathbf{6 1 0}$ \\
\hline
\end{tabular}

Complete flakes are unbroken flakes that have a dorsal and ventral surface with an intact platform, termination, and unaltered margins. Proximal flake fragments are flakes that have an intact platform and bulb of percussion, but are missing a termination due to transverse breakage. Broken flakes are lateral, medial, or distal flake fragments that are identifiable as flakes by their dorsal and ventral surface. However, due to breakage, broken flakes are missing a platform. Rock shatter are chipped stone artifacts produced from fracturing rock but due to breakage, weathering, or other taphonomic processes lacking enough attributes (e.g. dorsal/ventral surface, platform) to unambiguously be described as flake (complete or broken). Similar to rock shatter, thermal shatter lack the attributes to be described as flake yet displayed certain heat exposure characteristics (potlidding, crazing, or reddening). Specimens exhibiting edge modification or possible use wear were culled and analyzed as modified flakes, discussed in the other lithic tools section.

Table 6.4. Density of Flakes vs. Non-flakes Per Context

\begin{tabular}{|c|c|c|c|c|}
\hline & \multicolumn{2}{|c|}{ Interface Deposit } & \multicolumn{2}{c|}{ In Situ Alluvium } \\
\hline Artifact Type & Count & Density* & Count & Density* \\
\hline Flakes & 209 & 134.84 & 301 & 172.00 \\
\hline Non-flakes & 55 & 35.48 & 45 & 25.71 \\
\hline Total Lithic Debitage & $\mathbf{2 6 4}$ & $\mathbf{1 7 0 . 3 2}$ & $\mathbf{3 4 6}$ & $\mathbf{1 9 7 . 7 1}$ \\
\hline
\end{tabular}

*Density is the approximate number of items per cubic meter of excavation.
During the excavation of the hand excavation units, obvious chert gravels were generally discarded from the screened matrix as non-cultural material. However, it was observed that a large quantity of these gravels was present in the disturbed interface layer, mixed in with the otherwise cultural material. This observation helped make the determination that the deposit was not in fact an intact cultural component. To see if the recovered debitage showed any similar trend, a comparison was conducted between the flake and non-flake (rock shatter and thermal shatter category) material from the disturbed interface and the intact alluvium. The ratio for each context is somewhat illustrative. The disturbed interface deposit had a density of approximately 134 flakes per cubic meter excavated while the intact cultural deposits had a flake density of approximately 172 flakes per cubic meter excavated (Table 6.4; Figure 6.6). In terms of flakes versus non-flakes, the disturbed interface deposit contains one non-flake piece of debitage (rock and thermal shatter) to every 3.8 flakes, as opposed to the intact cultural deposits in which there is one non-flake to every 6.7 flakes. This overall higher ratio of non-flake debitage, or shatter, in the disturbed interface context, coupled with the geomorphology investigations, supports the interpretation of a disturbed deposit.

The aim of the initial attribute category sort was to acquire information on the variety, physical condition, and distribution of the debitage assemblage. In turn, the isolation of these categories allowed for the complete flakes to be subjected to a size-sort analysis. Using a methodology similar to that outlined in Henry et al. (1976), Stahle and Dunn (1982), and Ahler (1989), the assemblage of complete flakes was size sorted into seven size classes - from less than $10 \mathrm{~mm}$ to greater than $60 \mathrm{~mm}$ - for each unit/level (Table 6.5). The objective of the size sort was to reveal patterns indicative of reduction strategies and vertical displacement of artifacts from post-depositional influences to establish the vertical integrity of the deposits (Nickels et al. 2003). The size sorting provided a general estimate of the size of parent material being worked. Additionally, drawing upon previous studies (Vierra 1997 and 


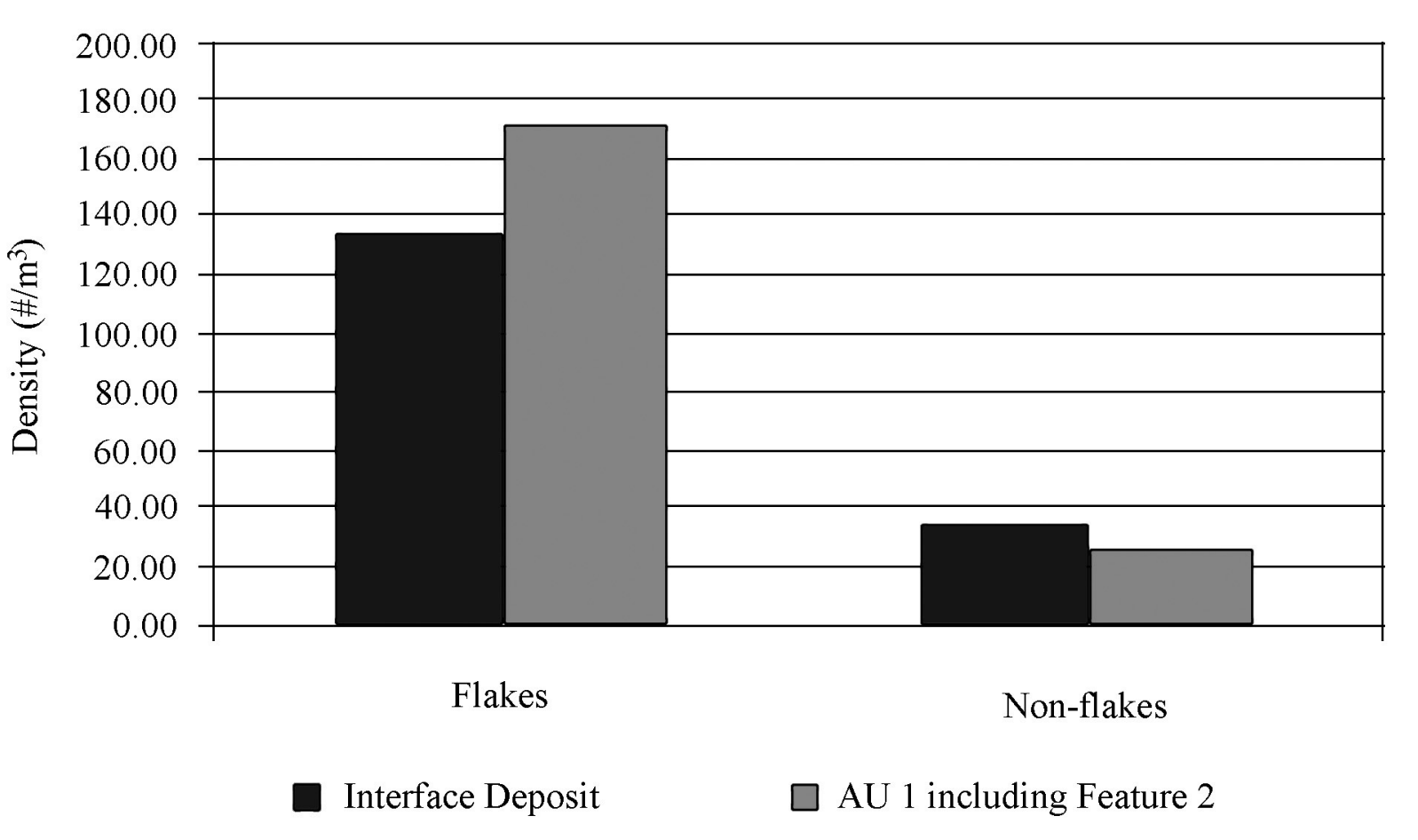

Figure 6.6. Density of flakes vs. non-flakes per context.

Nickels et al. 2003), the size-sort analysis helped in examining the vertical movement of artifacts through soil horizons.

Supplementing the size sort, a detailed individual flake analysis was conducted on the site's platformbearing flakes (i.e., complete flakes and proximal flake fragments). This analysis aided in determining the lithic reduction strategies throughout the site. The individual flake analysis recorded five nominal attributes for each proximal or complete flake specimen. Nominal attributes included both technological

Table 6.5. Size Sorted Complete Flakes from 41SS164

\begin{tabular}{|l|c|}
\hline Size Categories & Total \\
\hline$<60 \mathrm{~mm}$ & 1 \\
\hline $50-59.9 \mathrm{~mm}$ & 2 \\
\hline $40-49.9 \mathrm{~mm}$ & 5 \\
\hline $30-39.9 \mathrm{~mm}$ & 13 \\
\hline $20-29.9 \mathrm{~mm}$ & 31 \\
\hline $10-19.9 \mathrm{~mm}$ & 61 \\
\hline$>10 \mathrm{~mm}$ & 9 \\
\hline Size Total & $\mathbf{1 2 2}$ \\
\hline
\end{tabular}

and physical variables, including: flake type and subtype, raw material, percentage of dorsal cortex, and heat exposure.

The subtypes of complete flakes and proximal flake fragments consisted of core reduction flakes, biface thinning flakes, tool resharpening flakes, and indeterminate flakes (Table 6.6). A core reduction flake is generally a thicker flake with a large platform and cortex frequently on dorsal surface. These flakes are usually the result of hard hammer reduction. Biface thinning flakes are generally thinner flakes with a

Table 6.6. Complete and Proximal Flakes by Subtype from 41SS164

\begin{tabular}{|l|c|}
\hline Flake Subtype & Total \\
\hline Biface Thinning Flakes & 124 \\
\hline Core Reduction Flakes & 51 \\
\hline Tool Resharpening Flakes & 0 \\
\hline Indeterminate Flakes & 45 \\
\hline Flake Total & $\mathbf{2 2 0}$ \\
\hline
\end{tabular}


multifaceted or abraded platforms. Negative scars on the dorsal surface of these flakes are opposing and often overlap remnant flake scars. Tool resharpening flakes often exhibit use wear along the dorsal margin of the flake platform. These are difficult to identify and as such, none were identified at site 41SS164. And finally, indeterminate flakes are flakes that do not exhibit identifiable attributes or share any characteristics with the types listed above.

Overall, the above categories and attributes were chosen based on their potential to provide information on the lithic reduction strategies and vertical displacement of artifacts in site 41SS164. By identifying the individual flake attributes, inferences can be made on the reduction strategies present throughout the site. In addition, the size-sorting will either aid in correlating artifacts with multiple occupation levels present at the site, if any, or support the mixed assemblage interpretation resulting from the field observations.

\section{INTERPRETATION}

The limited analysis of the debitage recovered allowed for a general understanding of lithic reduction strategies and vertical displacement at site 41SS164. Considering that $3.28 \mathrm{~m}^{3}$ of soil was excavated at site 41SS164, the 610 pieces of debitage represented a generally low debitage count in relation to other sites tested in the area ${ }^{1}$. Of the 610 flakes, only 122 were complete flakes and 98 were proximal flakes, representing 36 percent $(n=220)$ of the entire recovered debitage. Of the 220 complete and proximal flakes, 55 percent were subtyped as biface thinning flakes. This suggests general late stage reduction practices from the recovered assemblage. To determine if the Feature 2 deposits had a different outcome when the debitage from the disturbed context and the lower intact deposits were removed, the ratio of each subtype from Feature 2 was compared to the other debitage subtypes from the other deposits. In all, 95 complete and proximal flakes were recovered from the disturbed context deposits with 109 recovered in association with Feature 2 and 16 in the intact deposits beneath Feature 2. As Table 6.7 shows, a similar relative ratio of subtype categories of flakes was attained from the disturbed interface deposit and the Feature 2 deposits. Therefore, the inclusion of the interface deposit and Feature 2 debitage does not change the assumption of general late stage reduction practices at site $41 \mathrm{SS} 164$.

As far as the size sort analysis, the debitage size classes were compared with the elevations of recovery under the assumption that a larger proportion of smaller flakes at lower elevations show vertical displacement through natural processes. However, this was not the case with a general equal distribution of artifacts from each size class throughout each level (Table 6.8). This suggests that the cultural materials have an original relation with the deposits from which they were recovered. Overall, although the debitage analysis suggests late stage tool reduction practices and no vertical displacement at site 41SS164, the general low number of artifacts must be taken into account before accepting these conclusions.

A review of the recorded cortex attributes from the complete and proximal flakes revealed 27 percent $(\mathrm{N}=60)$ of the 220 analyzed flakes containing some percentage of cortex. Of the analyzed complete flakes with cortex $(\mathrm{N}=38), 26$ were classified as core reduction flakes. This high percentage of cortical flakes and high number of core reduction flakes suggest the generally accepted embedded procurement

Table 6.7. Ratio of Complete and Proximal Flakes by Recovered Context

\begin{tabular}{|c|c|c|c|c|c|c|}
\hline \multirow{2}{*}{ Recovered Context } & \multicolumn{2}{|c|}{ Biface Thinning } & \multicolumn{2}{c|}{ Core Reduction } & \multicolumn{2}{c|}{ Indeterminate } \\
\cline { 2 - 8 } & Count & Ratio & Count & Ratio & Count & Ratio \\
\hline Interface Deposit & 51 & $54 \%$ & 23 & $24 \%$ & 21 & $22 \%$ \\
\hline AU 1 (Feature 2) Deposits & 63 & $58 \%$ & 27 & $25 \%$ & 19 & $17 \%$ \\
\hline Intact Deposits below AU 1 & 10 & $63 \%$ & 1 & $31 \%$ & 5 & $31 \%$ \\
\hline
\end{tabular}

${ }^{1}$ For example, the McCann Site did not report debitage but had 1,630 projectile points and 766 chipped stone tools. 
Table 6.8. Distribution of Complete Flakes by Size Class and General Elevation Range

\begin{tabular}{|c|c|c|c|c|c|c|c|c|}
\hline Elevation (m) & $<10 \mathrm{~mm}$ & $10-19.9 \mathrm{~mm}$ & $20-29.9 \mathrm{~mm}$ & $30-39.9 \mathrm{~mm}$ & $40-49.9 \mathrm{~mm}$ & $50-59.9 \mathrm{~mm}$ & $>60 \mathrm{~mm}$ & Total \\
\hline $98.2-98.0$ & & 1 & & & 1 & & & 2 \\
\hline $98.1+$ & 2 & 11 & 5 & 3 & 1 & & & 22 \\
\hline $98.1-98.0$ & 1 & 4 & 3 & & & 1 & & 9 \\
\hline $98.0-97.9$ & 1 & 10 & 1 & 1 & & & & 13 \\
\hline $98.0-97.8$ & 1 & 5 & 4 & & & & & 10 \\
\hline $97.9-97.8$ & 1 & 4 & 6 & 1 & & & & 12 \\
\hline $97.8-97.7$ & & 4 & 4 & 3 & & & 1 & 12 \\
\hline $97.7-97.6$ & 2 & 12 & 4 & 2 & & 1 & & 21 \\
\hline $97.6-97.5$ & 1 & 6 & 4 & 1 & 2 & & & 14 \\
\hline $97.5-97.4$ & & 2 & & & 1 & & & 3 \\
\hline $97.4-97.3$ & & 1 & & & & & & 1 \\
\hline $97.4-97.2$ & & 1 & & & & & & 1 \\
\hline $97.3-97.2$ & & & & 2 & & & & 2 \\
\hline Size Total & 9 & 61 & 31 & 13 & 5 & 2 & 1 & 122 \\
\hline
\end{tabular}

strategy indication that lithic sources tend to be in close proximity to the site locations (Binford 1979). With this indication, Richland Springs Creek is likely the source of the chert debitage parent material based on the proximity of the site to the creek. An assessment of the local geology showed a wide range of chert bearing limestone including the Marble Falls, Travis Peak, and Gorman formations laying up creek from the site location (Kier el al. 1995). The characteristic color variation demonstrated in central Texas cherts, especially with the sites proximity to the unique mineral region of the Llano uplift, limits identifying chert sources. The heterogeneous nature of these cherts has caused them to be generalized as "Edwards Chert", which represents any gray or tan chert found in West Texas and the Southern Plains (Frederick and Ringstaff 1194; Tunnell 1978; Hoffman et al. 1991).

The limited amount of debitage recovered from the intact AU 1 deposits and the compression of those deposits prevented an in-depth study and comparative analysis of lithic resources of the area. As previously noted in Chapter 5, the AU 1 dates to the Early Archaic (8,800-6,000 B.P.) or Middle Archaic $(6,000-4,000$ B.P.) period, based on the presence of one Pandale dart point, and to the Late Archaic period, based on a radiocarbon date $(2,900 \pm 40$ B.P.) recovered from TU 2, level 6, at the same level as the Pandale point $(97.69 \mathrm{~m})$. Therefore, AU 1 shows evidence of limited stratigraphic separation and considerable compression of many centuries of deposits. Because of the inability to isolate temporal affiliation to the lithic artifact assemblages, an in-depth study and comparative analysis of lithic debitage to investigations in the area was infeasible. Chapter 8 expands on this point with the site and comparative analyses.

\section{Artifact Distributions}

As noted earlier, the primary intact deposit and highest artifact density occur in association with Feature 2, which occurred from 97.9-97.5 $\mathrm{m}$ in elevation. TUs 2, 4, and the column sample (CS 1) were excavated below the levels associated with Feature 2 with TU 2 and CS 1 extending to a depth of $97.2 \mathrm{~m}$ and TU 4 extending to $97.4 \mathrm{~m}$. These lower elevations displayed a decreasing amount of cultural materials with depth. In addition, the projectile point, formal tools, groundstone, and cores recovered in the intact cultural deposits were recovered in context associated with Feature 2.

${ }^{2}$ TU 4 was combined into the TU 2 average due to TU 4 being an additional excavated 1-x-1-m unit beneath the eastern $1-\mathrm{x}-1 \mathrm{~m}$ portion of TU 2. 
Based on varying depths and sizes of the test units and column sample excavated during testing, the average artifact count for a $1-\mathrm{x}-1-\mathrm{m}, 10-\mathrm{cm}$ thick layer $\left(0.1 \mathrm{~m}^{3}\right)$ from each unit was calculated to determine the varying horizontal rate of recovery. This was determined by taking the total artifact count recovered from each unit and dividing by the number of levels excavated. In the case of TU 2 (a 1-x-2-m unit $\left[0.2 \mathrm{~m}^{3}\right]$ ) and the column sample (a $0.5-\mathrm{x}-0.5-\mathrm{m}$ unit $\left.\left[0.05 \mathrm{~m}^{3}\right]\right)$, the total was adjusted to determine the average count for an average $0.1 \mathrm{~m}^{3}$ volume. In this case, the TU 2 sample was divided by two and the column sample was multiplied by two (accounting for the $20 \mathrm{~cm}$ excavated levels in the column sample). The results were as follows: TU 1 had an average of 23.6 artifacts per level, TU 2 had 17.4, TU 3 had 10.5, and CS 1 had 3.6 artifacts per level. ${ }^{2}$

Using these calculations, the highest artifact density was recovered from TU 1 , which was $1 \mathrm{~m}$ to the west of TU 2 on the western portion of the site. Recovery declined moving from the west to the east with TU 2 (including TU 4) having a relatively high average of recovery at 17.4 artifacts. Although TU 3 was located east and adjacent to TU 2 , the average amount of artifacts per level dropped off considerably. This includes a decline in the amount of tools and unique cultural materials (groundstone, cores, etc.) with one biface recovered among 20 pieces of lithic debitage. This trend continues to the column sample, placed $10 \mathrm{~m}$ east of the TU 3, with the recovery of nine pieces of lithic debitage and no additional cultural materials.

Although the majority of the artifacts from the excavation units and column sample were recovered from a vertical placement in association with AU 1 $(n=351$, of which 261 were associated with Feature 2 ), a relatively high number of artifacts were recovered from the disturbed interface deposit $(n=276)$. A substantially less amount of artifacts, consisting solely of lithic debitage, were recovered from the intact deposits below the levels associated with $\mathrm{AU}$ $1(n=20)$ with only four flakes found in the last level of TU 1 excavated at an elevation of 97.3-97.2 m.

With only one diagnostic tool (Pandale projectile point) recovered from the testing investigations, determining the chronological sequence of the in- tact stratigraphic deposits had to utilize other time markers. These included the radiocarbon dates and the results of the geomorphology investigations. As previously stated, Pandale points are placed in the Middle Archaic period and mostly found in the Lower Pecos (Shafer 1986). Of note, Turner and Hester (2002) attribute the Pandale to the Early Archaic. However, the actual dates attributed to the Pandale are similar regardless of the source. For example, Pandales are dated to $6,000-4,500$ B.P. by Turner and Hester (2002) and to 5,500-4,100 B.P. by Black and Dering's (2007) Lower Pecos chronology. In addition, the uncorrected 4,690 \pm 140 B.P. radiocarbon date from Baker Cave (Hester 1983:104) was obtained just below a distinctive Pandale occupation.

A radiocarbon date was recovered from TU 2, level 6 , at the same level as the Pandale point (97.69 m). However, the returned date of $2,900 \pm 40$ B.P. was far younger than the dates attributed to the Pandale. In addition, a radiocarbon date recovered from the intact deposits associated with Feature 2 in TU 3 $(97.91 \mathrm{~m})$ returned a date of $200 \pm 40$ B.P. However, this sample was recovered approximately $20 \mathrm{~cm}$ higher in elevation near the contact point between the intact Feature 2 deposits and the disturbed interface deposit (around $97.9 \mathrm{~m}$ in elevation). The two remaining radiocarbon samples were recovered in the disturbed interface deposits with dates of $230 \pm 40$ в.P. $(98.07 \mathrm{~m})$ and $270 \pm 40$ B.P. $(98.0 \mathrm{~m})$. Based on the radiocarbon dates, the geomorphology assessment, and the recovered diagnostic artifact, the deposits associated with Feature 2 and those below it are the only undisturbed soils within the investigated units. The location of the younger radiocarbon sample from the higher elevations of the Feature 2 deposits and the similar dates with the radiocarbon samples from the disturbed interface suggests possible permeation of carbon from a higher elevation into the upper elevations of Feature 2.

Based on the available time markers, the intact deposits were determined to have limited stratigraphic separation and considerable compression. If the younger radiocarbon date recovered from the contact point between the intact Feature 2 deposits and the disturbed interface deposits is attributed to the intact cultural deposits, then the deposits exhibit approximate 4,500 years compression within $30 \mathrm{~cm}$. 
6-12 Chapter 6

Additionally, the date of the radiocarbon sample found in the same unit and level as the Pandale point suggests a compression of $1,000-1,500$ years within $10 \mathrm{~cm}$. 


\title{
Chapter 7
}

\section{Data Set for Comparative Literature Review}

\author{
Mindy L. Bonine and Michael R. Chavez
}

\section{INTRODUCTION}

As part of the general analysis of site 41SS164, three studies were conducted to assist in placing site $41 \mathrm{SS} 164$ in a wider historic context. The first was to gather and tabulate basic data of all of the previously recorded archaeological sites (as of June 2007) located in a selected research area. The purpose of gathering such data is to conduct a comparative analysis in order to determine if site 41SS164 is a typical site type (defined here as a site that contains cultural material indicative of particular activities, i.e., burned rock middens or lithic scatters) in the research area (typology) or was occupied during the same period as other sites in the research area (chronology).

The second study was to obtain information on a select number of archaeological sites in the research area that have been investigated beyond the basic recording stage, and conduct a comparative analysis between these sites and 41SS164. Again, the purpose is to see if what is known about 41SS164 resonates with the archaeological record through the investigation of other sites in the research area.

Finally, because of the presence of burned rock features at site 41SS164, a closer look at investigations of burned rock features from central Texas was undertaken. These included investigations at Fort Hood in Coryell and Bell Counties, Camp Bowie in Brown County, and a study on four burned rock midden sites along the western Edwards Plateau (Trierweiler 1994; 1996; Maudlin et al. 2003; Black et al. 1997). A discussion of the results of the comparative analysis is presented in Chapter 8. The data used in that analysis is described below.

\section{Defining The Research Area}

In order to place the information gathered from the testing of site $41 \mathrm{SS} 164$ into a wider regional prehistoric context, the available information on other archaeological sites in a predetermined research area must be compiled and synthesized into a usable form. A key decision in this process is defining the limits of the research area; this determines what sites will be included in the analysis and those that will be excluded. Choosing what will comprise a data set for comparative analysis depends largely on the research questions asked and the focus of the analysis, whether it is based on time or space, be it macro-scale or micro-scale, or concentrating on particular site attributes. To this end, archaeologists generally use some form of geographic boundary to limit the research area. These limits have included political boundaries, such as current county or state limits; absolute distances, as in a measured radius around the site in question; physiographic limits, such as the Edwards Plateau region; or archaeologically defined prehistoric culture areas, as in the Central Texas archaeological region.

The research area that has been defined in this analysis is based on the confluence of three natural subregions of Texas: the Llano Uplift, Mesquite Plains (a subregion of the Rolling Plains), and the Lampasas Cut Plain (part of the Edwards Plateau) (The Natural Heritage Policy Research Project [NHPRP] 1978) (Figure 7.1). The Rolling Plains are the southern extension of the Great Plains which covers much of the central portion of the continental United States and into Canada. The terrain of the Rolling Plains is characterized as gently sloping to hilly as a result of varying erosion to primarily Paleozoic rock formations (Mauldin et al. 2003). The subregion of the Rolling Plains physiographic region at this confluence is known as the Mesquite Plain. The Mesquite Plain subregion typifies the Rolling Plains region with gently rolling plains of mesquite-short grass savannas (NHPRP 1978). The Edwards Plateau is an 


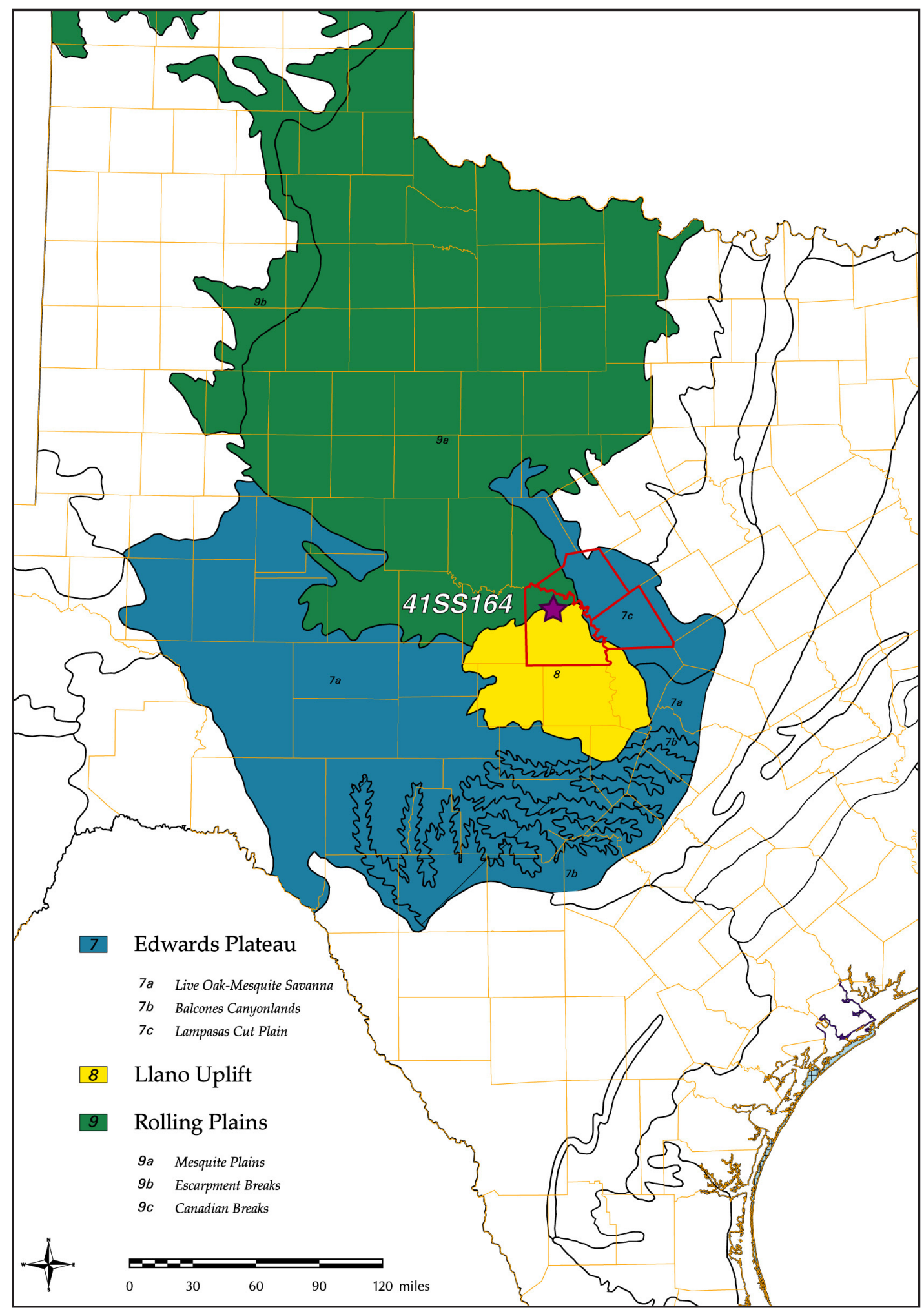

Figure 7.1. Selected Natural Subregions of Texas (NHPRP 1978). The tri-county research area is highlighted in red. 
uplifted and dissected area south of the Rolling Plains made of thick Cretaceous limestone covering central Texas. It is bounded by the semi-circular Balcones Escarpment, which marks its abrupt southern and eastern margin (Black et al. 1997). Its easternmost subregion, the Lampasas Cut Plain, borders the Llano Uplift to the east. The Lampasas Cut Plain is described as grassland with scattered mesquite woods on low rolling hills underlain by limestone (NHPRP 1978). The Llano Uplift is a roughly circular geologic dome of primarily Precambrian granitic and metamorphic rock virtually surrounded by the Edwards Plateau. The region ${ }^{1}$ is characterized by a central exposure of Precambrian granite surrounded by a ring of gneiss and schist enclosed by limestone. Common vegetation to the area consists of oak and oak-hickory woodlands with mesquite savannas and some grassland (NHPRP 1978).

In San Saba County, the location of 41SS164 is very close to the dividing line between two of these subregions. It is situated on the Llano Uplift and is only a few hundred meters south of the Mesquite Plains. Of greater importance, however, the site is only about $22 \mathrm{~km}$ west-southwest of the confluence of all three subregions, the Mesquite Plains, Lampasas Cut Plain, and Llano Uplift. Given the close proximity of the site to these three natural subregions of Texas, it was determined that instead of focusing on the physiographic or political boundaries the site is within, the research area should include the crossroads between different areas. Thus, if there are any observable differences in sites as one crosses from one natural region to the next, it might be visible if this type of research area is selected. For ease of gathering pertinent data for the research outlined in this report, the outer political limits of San Saba, Mills, and Lampasas Counties marked the extent of research and data acquisition (Figure 7.2). These modern political boundaries of the three counties has allowed for an average approximate radius of 27 miles from the point of confluence of the three physiographic regions. The area encompasses approximately 2,584 square miles of flat to rolling prairie (Mesquite Plains), steeply to moderately sloping hills (Lampasas Cut Plains), and rougher dissected terrain (Llano Uplift). The Colorado River bisects the tri-county area, placing it in a portion of the Colorado River drainage basin with the San Saba River and Pecan Bayou being the two major drainages into the river basin.

The prevailing conceptual model is that prehistoric inhabitants of the Central Texas archaeological region were mobile hunter-gatherer groups that utilized a diversity of resources across the landscape. An analysis of site types in different natural subregions may lead to a realistic interpretation of settlement patterns, foraging strategies, and resource utilization (Binford 1980; Butzer 1982; Trigger 1967; Winterhalder and Smith 1981). If, in fact, these mobile hunter-gatherer groups concentrated their activities around an area where many different types of resources can be found, and at different seasons, using a research area that combines three different natural subregions may be enlightening.

\section{Archaeological Sites in Mesquite Plains, Lampasas Cut Plains, and the Llano Uplift Research Area}

To locate and tabulate all of the previously recorded sites in the San Saba, Mills, and Lampasas research area, a large USGS 7.5 minute topographic map was printed of the research area, and the names of all the quadrangle sheets were compiled. An archaeological technician then accessed the Texas Archeological Sites Atlas (Atlas) to compile the recorded archaeological site trinomials in each quadrangle sheet and entered these sites into a spreadsheet. The technician then completed the spreadsheet, recording the site type, landform, archaeological period, diagnostic tools, and features. The data for each site that was available on the Atlas was first completed, and all of the remaining data was researched from several trips to TARL to access their paper site files. In addition to the spreadsheet, the sites were plotted on the large scale map and separated into their respective natural subregion, be it the Mesquite Plains, the Lampasas Cut Plains, or the Llano Uplift. A total of 330 sites

\footnotetext{
${ }^{1}$ The Llano Uplift has no subregions, but to ease the terminology in following discussions, it will be referred to generally as a subregion along with the other natural subregions.
} 


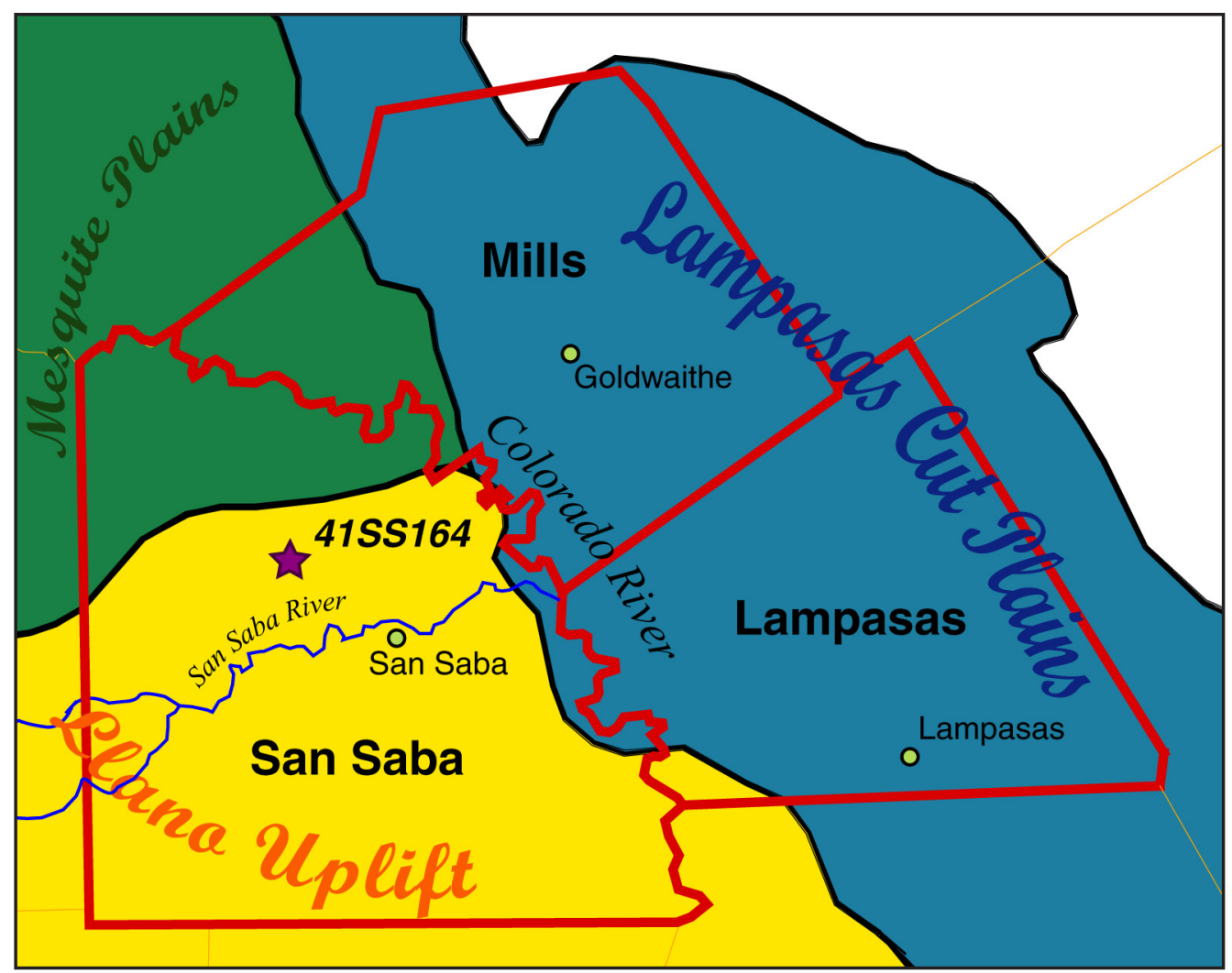

Figure 7.2. Close-up of the tri-county research area, San Saba, Mills, and Lampasas Counties. Note the point where the natural subregions converge at the Colorado River.

were found in the tri-county research area, and only six neither have any associated information nor were plotted on the Atlas or TARL maps. Only 11 had no associated information other than their location. Fifty-two of the 330 recorded sites were historic-era sites with no prehistoric components.

The raw data compiled from the Atlas and TARL site files replicated whatever information the forms and associated materials contained, using the same terminology on those forms. The only category where this was not the case is "landform." The archaeological technician utilized a preset list of terms to describe different landforms, and either matched them to the descriptions on the site forms, or made a determination based on the location of the site on the topographic maps. In general, the landform terms used here matched those on the site forms, but some minor adjustments were made. This was one of the most critical categories to synthesize, as further analysis would sort the data based on these categories. The following defines the categories used.
Hillslope: a topographic area that is sloping at an angle greater than 20 degrees, and typically much steeper, between a higher elevation and a lower one.

Hilltop: a topographic area that is the nearly-level upper surface of a hill. In the case of the Edwards Plateau, generally the top of the plateau near were it has been incised by drainages and other waterways.

Hilltop/Slope: a combination of both the hilltop and the hillslope. Sites found in these locations are generally eroding down from the upper elevations.

Terrace: a topographic area consisting of a relatively level bench or step-like surface breaking the continuity of a slope, generally located above a stream channel. Several terraces can be leading away from the channel.

Floodplain: a topographic area below a terrace and immediately within or adjacent to a water source. 
These areas generally contain frequently flooded alluvial surfaces.

Upland drainage: a topographic area consisting of a high elevation headwater drainage leading down towards larger waterways, and its associated "banks." Sites found in these locations area generally cradled within the V-shaped depression in the landscape.

Once the data for all the categories we recorded on the spreadsheet, the data was first sorted by natural subregion, and then by the "landform" category and the "site type" category. Sites that did not have any associated location or other information, or were entirely historic-age, were removed from the analysis $(\mathrm{n}=58)$.

At this point some discussion of the reasons behind categorizing the data set by natural subregion and "landform," which is basically a topographic setting, is warranted. As described above, this study is taking a somewhat processual viewpoint in that prehistoric peoples made cultural adaptations based on their environmental conditions, including the straightforward action of exploiting whatever local resources could be found, and processing them at or near the places where they can be found. This includes choosing a campsite or habitation site best suited for a certain activity or series of activities based on an environmental setting (e.g., topographic, floral and faunal, etc.). Sorting the data set by these categories helps to link other site attributes to this concept of campsite choice and resource exploitation.

After the six sites with no associated information and the 52 historic sites were removed from the data set, the interpretation of the data began. The first step was to standardize terminology. Over several decades of site recording, researchers have used different terms for similar sets of site attributes, from descriptions of features as in "burned rock midden sites," to a type of habitation area (implying both size and length of occupation) as in "campsite" or "village." The most diverse set of terminology was used for sites that contain predominantly debitage and worked tools, including "lithic procurement," "lithic production," "lithic scatter," "lithic reduction," "workshop," or some combination thereof. These terms and others like them were synthesized into 14 defined types, based on the incidence of related terms and a review of site attributes. Open campsites were separated into two categories, those with burned rock middens and those with either hearths or scattered burned rock. Sites with two or more identifiable features, such as open campsites with burials or rockshelters with pictographs, were classified by the primary site type. Sites with just one feature (for example, mortar holes, burials, or pictographs) were listed as a separate site type. For clarification, the term "multi-component" in this narrative only refers to archaeological sites that have both a prehistoric component and a historic component. A summary of the 272 total number of sites used in the comparative analysis is divided by region and presented in Tables 7.1-7.3.

\section{"Tested" Archaeological Sites in The Tri-county Research Area}

\section{Criteria for Comparative ANALysis}

Today, site testing has come to mean additional research in the form of site excavations and artifact analysis to answer specific research questions and determine if a site contains enough information to be significant, and thus eligible under Criterion $\mathrm{D}$ for listing on the NRHP or for designation as an SAL. Several decades ago, when many of these sites were tested, specific eligibility recommendations were not generally made (or were not reported), and the value of the site was judged in more general terms. Similarly, the methods of data gathering and the presentation of the results were also less regulated. In fact, several reports of this era document investigations that go beyond basic site recording, but would not qualify as a Section 106 "testing" report by today's standards. However, for the purposes of this comparative analysis, the information provided in these reports is very helpful.

There are a relatively small number of recorded sites in the San Saba, Mills, and Lampasas Counties research area, and there are an even smaller number that have been investigated beyond the recording stage. Of the 330 sites in the study area, only four sites were chosen for the comprehensive comparative analysis (Figure 7.3). These sites were selected 


\section{7-6 Chapter 7}

Table 7.1. Previously Recorded Sites in the Lampasas Cut Plains

\begin{tabular}{|c|c|c|c|c|c|}
\hline Site & Site Type & Landform & Archaeological Periods & Diagnostic Tools & Features \\
\hline $41 \mathrm{MI} 3$ & Isolate & Floodplain & Unknown Prehistoric & None & None \\
\hline 41LM15 & Isolate & Hillslope & Unknown Prehistoric & None & None \\
\hline 41LM13 & Isolate & Terrace & Unknown Prehistoric & None & None \\
\hline 41LM14 & Isolate & Terrace & Unknown Prehistoric & None & None \\
\hline $41 \mathrm{MI} 37$ & Lithic Procurement & Hillslope & Unknown Prehistoric & None & None \\
\hline $41 \mathrm{MI} 38$ & Lithic Procurement & Hillslope & Unknown Prehistoric & None & None \\
\hline 41MI39 & Lithic Procurement & Hillslope & Unknown Prehistoric & None & None \\
\hline 41LM46 & Lithic Procurement & Hillslope & Unknown Prehistoric & None & None \\
\hline 41LM47 & Lithic Procurement & Hillslope & Unknown Prehistoric & None & None \\
\hline $41 \mathrm{MI} 57$ & Lithic Procurement & Hillslope & Unknown Prehistoric & None & None \\
\hline 41LM45 & Lithic Procurement & Hillslope & Unknown Prehistoric & None & None \\
\hline 41LM29 & Lithic Procurement & Hilltop & Unknown Prehistoric & None & None \\
\hline $41 \mathrm{Ml} 49$ & Lithic Procurement & Hilltop & Unknown Prehistoric & None & None \\
\hline 41MI59 & Lithic Procurement & Hilltop & Unknown Prehistoric & None & None \\
\hline 41MI99 & Lithic Procurement & Hilltop/Slope & Unknown Prehistoric & None & None \\
\hline 41LM44 & Lithic Procurement & Hilltop/Slope & Unknown Prehistoric & None & None \\
\hline 41SS53 & Lithic Procurement & Terrace & Unknown Prehistoric & None & None \\
\hline 41MI97 & Lithic Procurement & Upland Drainage & Unknown Prehistoric & None & None \\
\hline $41 \mathrm{MI} 42$ & Lithic Scatter & Hillslope & Unknown Prehistoric & None & None \\
\hline 41LM56 & Lithic Scatter & Hillslope & Unknown Prehistoric & None & None \\
\hline $41 \mathrm{MI} 46$ & Lithic Scatter & Hillslope & Unknown Prehistoric & None & None \\
\hline 41LM32 & Lithic Scatter & Hillslope & Unknown Prehistoric & None & Not Reported \\
\hline $41 \mathrm{MI} 33$ & Lithic Scatter & Hillslope & $\begin{array}{c}\text { Unknown Prehistoric/ } \\
\text { Historic }\end{array}$ & None & Burial Cairn \\
\hline 41MI98 & Lithic Scatter & Hillslope & Unknown Prehistoric & None & None \\
\hline 41MI52 & Lithic Scatter & Hilltop & Unknown Prehistoric & None & None \\
\hline 41LM50 & Lithic Scatter & Terrace & Unknown Prehistoric & Unknown & Unknown \\
\hline 41LM51 & Lithic Scatter & Terrace & Unknown Prehistoric & Unknown & Unknown \\
\hline $41 \mathrm{MI} 5$ & Lithic Scatter & Upland Drainage & Archaic & Arrow points & None \\
\hline $41 \mathrm{MI} 58$ & $\begin{array}{l}\text { Lithic Scatter/ } \\
\text { Procurement }\end{array}$ & Floodplain & Archaic & Dart point & None \\
\hline 41MI51 & $\begin{array}{l}\text { Lithic Scatter/ } \\
\text { Procurement }\end{array}$ & Hillslope & Unknown Prehistoric & None & None \\
\hline $41 \mathrm{MI} 54$ & $\begin{array}{l}\text { Lithic Scatter/ } \\
\text { Procurement }\end{array}$ & Hillslope & Unknown Prehistoric & None & None \\
\hline 41MI55 & $\begin{array}{l}\text { Lithic Scatter/ } \\
\text { Procurement }\end{array}$ & Hillslope & Unknown Prehistoric & None & None \\
\hline 41LM11 & $\begin{array}{l}\text { Lithic Scatter/ } \\
\text { Procurement }\end{array}$ & Hilltop/Slope & Unknown Prehistoric & None & None \\
\hline 41LM10 & $\begin{array}{l}\text { Lithic Scatter/ } \\
\text { Procurement }\end{array}$ & Terrace & Unknown Prehistoric & None & None \\
\hline 41LM12 & $\begin{array}{l}\text { Lithic Scatter/ } \\
\text { Procurement }\end{array}$ & Terrace & Unknown Prehistoric & None & None \\
\hline 41LM33 & $\begin{array}{l}\text { Lithic Scatter/ } \\
\text { Procurement }\end{array}$ & Terrace & Unknown Prehistoric & None & Not Reported \\
\hline 41SS59 & Multicomponent & Hillslope & $\begin{array}{c}\text { Unknown Prehistoric/ } \\
\text { Historic }\end{array}$ & Historics & Structures \\
\hline
\end{tabular}


Table 7.1. Previously Recorded Sites in the Lampasas Cut Plains, continued

\begin{tabular}{|c|c|c|c|c|c|}
\hline Site & Site Type & Landform & Archaeological Periods & Diagnostic Tools & Features \\
\hline $41 \mathrm{MI} 47$ & Multicomponent & Terrace & Archaic/Historic & $\begin{array}{c}\text { Glass, Frio, Martindale, } \\
\text { and Marshall }\end{array}$ & $\begin{array}{c}\text { Cistern and House Foun- } \\
\text { dation }\end{array}$ \\
\hline 41LM58 & Multicomponent & Terrace & $\begin{array}{c}\text { Unknown Prehistoric/ } \\
\text { Historic }\end{array}$ & None & Rock Wall and Midden \\
\hline 41LM27 & Multicomponent & Terrace & $\begin{array}{c}\text { Unknown Prehistoric/ } \\
\text { Historic }\end{array}$ & Historics & $\begin{array}{l}\text { Hanna Springs Pool and } \\
\text { Ruins of Bath House, and } \\
\text { Archaeological Remains } \\
\text { of the Scott Hotel }\end{array}$ \\
\hline 41LM25 & Not Reported & Floodplain & Not reported & Not reported & Not reported \\
\hline 41LM26 & Not Reported & Floodplain & Not reported & Not reported & Not reported \\
\hline 41MI63 & Not Reported & Hillslope & Not reported & Not reported & Not reported \\
\hline 41MI56 & Not Reported & Hillslope & Not reported & Not reported & Not reported \\
\hline 41LM53 & Open Campsite & Floodplain & Late Archaic & Ensor-like point & None \\
\hline $41 \mathrm{Ml} 6$ & Open Campsite & Floodplain & Unknown Prehistoric & None & None \\
\hline 41MI62 & Open Campsite & Floodplain & Unknown Prehistoric & None & Hearths \\
\hline 41LM22 & Open Campsite & Floodplain & Unknown Prehistoric & None & None \\
\hline 41LM43 & Open Campsite & Floodplain & Unknown Prehistoric & None & None \\
\hline $41 \mathrm{MI} 26$ & Open Campsite & Hillslope & Unknown Prehistoric & None & None \\
\hline $41 \mathrm{MI} 40$ & Open Campsite & Hillslope & Archaic & Dart points & None \\
\hline $41 \mathrm{MI} 41$ & Open Campsite & Hillslope & Archaic & Nolan & None \\
\hline $41 \mathrm{MI} 34$ & Open Campsite & Hillslope & Archaic & Dart points & None \\
\hline $41 \mathrm{MI} 36$ & Open Campsite & Hillslope & Archaic (?) & Dart points & None \\
\hline 41MI30 & Open Campsite & Hillslope & Late/Transitional Archaic & $\begin{array}{c}\text { Montell and Plano-con- } \\
\text { vex Thin Biface }\end{array}$ & None \\
\hline $41 \mathrm{MI} 43$ & Open Campsite & Hillslope & Unknown Prehistoric & None & None \\
\hline 41LM48 & Open Campsite & Hillslope & Unknown Prehistoric & None & None \\
\hline $41 \mathrm{MI} 32$ & Open Campsite & Hillslope & Unknown Prehistoric & None & None \\
\hline $41 \mathrm{MI} 44$ & Open Campsite & Hillslope & Unknown Prehistoric & None & None \\
\hline $41 \mathrm{MI} 100$ & Open Campsite & Hilltop & Late Archaic & Pedernales(2) & None \\
\hline $41 \mathrm{MI} 35$ & Open Campsite & Hilltop & Middle Archaic & Dart points & None \\
\hline $41 \mathrm{MI} 53$ & Open Campsite & Hilltop & Unknown Prehistoric & None & None \\
\hline 41LM54 & Open Campsite & Terrace & Archaic & $\begin{array}{c}\text { Dart points and Ensor } \\
\text { point }\end{array}$ & Not Reported \\
\hline 41LM8 & Open Campsite & Terrace & Unknown Prehistoric & None & None \\
\hline 41SS161 & Open Campsite & Terrace & Unknown Prehistoric & None & None \\
\hline $41 \mathrm{MI} 45$ & Open Campsite & Terrace & Archaic & Dart point & None \\
\hline 41SS137 & Open Campsite & Terrace & Archaic/Late Prehistoric & $\begin{array}{c}\text { Early Triangular, Travis, } \\
\text { and Arrow point }\end{array}$ & None \\
\hline 41SS136 & Open Campsite & Terrace & Unknown Prehistoric & None & None \\
\hline 41MI65 & Open Campsite & Terrace & Unknown Prehistoric & None & None \\
\hline $41 \mathrm{MI} 48$ & Open Campsite & Terrace & Unknown Prehistoric & None & None \\
\hline 41LM1 & Open Campsite & Upland Drainage & Unknown Prehistoric & Dart points & None \\
\hline 41MI64 & Open Campsite & Upland Drainage & Unknown Prehistoric & None & None \\
\hline $41 \mathrm{Ml} 1$ & Open Campsite & Upland Drainage & Unknown Prehistoric & None & None \\
\hline 41LM49 & $\begin{array}{l}\text { Open Campsite with } \\
\text { Midden }\end{array}$ & Floodplain & Unknown Prehistoric & None & Middens (2) \\
\hline
\end{tabular}




\section{7-8 Chapter 7}

Table 7.1. Previously Recorded Sites in the Lampasas Cut Plains, continued

\begin{tabular}{|c|c|c|c|c|c|}
\hline Site & Site Type & Landform & Archaeological Periods & Diagnostic Tools & Features \\
\hline 41LM28 & $\begin{array}{c}\text { Open Campsite with } \\
\text { Midden }\end{array}$ & Hillslope & $\begin{array}{c}\text { Late Paleoindian/Late } \\
\text { Prehistoric }\end{array}$ & $\begin{array}{c}\text { Angostura(2), Ellis, } \\
\text { Fairland, Gary, Guilford, } \\
\text { Marshall, Montell, } \\
\text { Zephyr, Cliffton, Gran- } \\
\text { bury, and Scallorn } \\
\end{array}$ & Midden \\
\hline $41 \mathrm{MI} 31$ & $\begin{array}{c}\text { Open Campsite with } \\
\text { Midden }\end{array}$ & Hillslope & Unknown Prehistoric & None & Midden \\
\hline 41LM35 & $\begin{array}{c}\text { Open Campsite with } \\
\text { Midden }\end{array}$ & Hilltop/Slope & Unknown Prehistoric & None & $\begin{array}{c}\text { Midden and Bedrock } \\
\text { Mortars }\end{array}$ \\
\hline 41LM36 & $\begin{array}{c}\text { Open Campsite with } \\
\text { Midden }\end{array}$ & Terrace & Unknown Prehistoric & None & $\begin{array}{c}\text { Midden and Bedrock } \\
\text { Mortars }\end{array}$ \\
\hline 41LM6 & $\begin{array}{c}\text { Open Campsite with } \\
\text { Midden }\end{array}$ & Terrace & Unknown Prehistoric & None & Midden \\
\hline 41LM23 & $\begin{array}{c}\text { Open Campsite with } \\
\text { Midden }\end{array}$ & Terrace & Archaic & Dart points(3) & Midden and Hearths \\
\hline 41LM24 & $\begin{array}{c}\text { Open Campsite with } \\
\text { Midden }\end{array}$ & Terrace & $\begin{array}{c}\text { Unknown Prehistoric/ } \\
\text { Historic }\end{array}$ & Bricks, Nails, Ceramics & Midden \\
\hline 41LM3 & $\begin{array}{l}\text { Open Campsite with } \\
\text { Midden and Burials }\end{array}$ & Hilltop/Slope & $\begin{array}{l}\text { Paleoindian-Late } \\
\text { Prehistoric }\end{array}$ & $\begin{array}{l}\text { Almost All Types of } \\
\text { points }\end{array}$ & Burials (2) and Middens \\
\hline 41LM9 & $\begin{array}{l}\text { Open Campsite with } \\
\text { Midden and Burials }\end{array}$ & Terrace & Toyah & Perdiz & Burials (6) and midden \\
\hline 41LM4 & Rockshelter & Upland Drainage & Unknown Prehistoric & Not Reported & Not Reported \\
\hline 41LM2 & $\begin{array}{l}\text { Rockshelter with Pic- } \\
\text { trographs and Burial }\end{array}$ & Hillslope & Unknown Prehistoric & & $\begin{array}{c}\text { Pictographs and Flexed } \\
\text { Burial }\end{array}$ \\
\hline $41 \mathrm{Ml} 4$ & $\begin{array}{l}\text { Rockshelter with } \\
\text { Midden }\end{array}$ & Upland Drainage & $\begin{array}{c}\text { Edwards Plateau/Central } \\
\text { Texas Aspects }\end{array}$ & Dart and Arrow points & Middens (5) \\
\hline 41LM16 & $\begin{array}{l}\text { Rockshelter with } \\
\text { Midden and Burial }\end{array}$ & Terrace & $\begin{array}{c}\text { Early Archaic/Late } \\
\text { Prehistoric }\end{array}$ & $\begin{array}{l}\text { Perdiz,Scallorn, Darl, } \\
\text { Ensor, Frio, Marcos, } \\
\text { Montell, Pedernales, } \\
\text { Bulverde, Travis/No- } \\
\text { lan, Martindale, Friday } \\
\text { Knife, and 1 Ceramic } \\
\text { Sherd }\end{array}$ & Midden and Burials (2) \\
\hline
\end{tabular}


Table 7.2. Previously Recorded Sites in the Llano Uplift

\begin{tabular}{|c|c|c|c|c|c|}
\hline Site & Site Type & Landform & Archaeological Periods & Diagnostic Tools & Features \\
\hline 41SS52 & "Buffalo Jump" & Hillslope & Unknown Prehistoric & None & Mound \\
\hline 41SS48 & Crevice Burial & Hillslope & Protohistoric/Historic (?) & Human Bone & Burial \\
\hline 41SS65 & Isolate & Floodplain & Unknown Prehistoric & None & None \\
\hline 41SS62 & Lithic Procurement & Floodplain & Unknown Prehistoric & None & None \\
\hline $41 S S 138$ & Lithic Procurement & Hillslope & Unknown Prehistoric & None & None \\
\hline $41 S S 123$ & Lithic Procurement & Hillslope & Unknown Prehistoric & None & None \\
\hline 41SS98 & Lithic Procurement & Hillslope & Unknown Prehistoric & None & None \\
\hline $41 S S 159$ & Lithic Procurement & Hilltop & Unknown Prehistoric & None & None \\
\hline 41SS105 & Lithic Procurement & Hilltop & Unknown Prehistoric & None & Bedrock Mortars \\
\hline 41SS109 & Lithic Procurement & Hilltop & Unknown Prehistoric & None & None \\
\hline $41 S S 118$ & Lithic Procurement & Hilltop & Unknown Prehistoric & None & None \\
\hline 41SS152 & Lithic Scatter & Floodplain & Unknown Prehistoric & None & None \\
\hline $41 S S 63$ & Lithic Scatter & Floodplain & Unknown Prehistoric & None & None \\
\hline $41 S S 70$ & Lithic Scatter & Hillslope & Archaic/Late Prehistoric & Dart and Arrow points & None \\
\hline 41SS14 & Lithic Scatter & Hillslope & $\begin{array}{c}\text { Paleoindian/Late Pre- } \\
\text { historic }\end{array}$ & Fresno and Folsom & None \\
\hline 41SS21 & Lithic Scatter & Hillslope & Unknown Prehistoric & None & None \\
\hline $41 S S 30$ & Lithic Scatter & Hillslope & Unknown Prehistoric & None & None \\
\hline 41SS31 & Lithic Scatter & Hillslope & Unknown Prehistoric & None & None \\
\hline $41 S S 143$ & Lithic Scatter & Hillslope & Unknown Prehistoric & None & None \\
\hline $41 S S 148$ & Lithic Scatter & Hillslope & Unknown Prehistoric & None & None \\
\hline 41SS61 & Lithic Scatter & Hillslope & Unknown Prehistoric & None & None \\
\hline $41 S S 150$ & Lithic Scatter & Terrace & $\begin{array}{c}\text { Late Archaic/Late Pre- } \\
\text { historic }\end{array}$ & $\begin{array}{l}\text { Castroville and Arrow } \\
\text { points }\end{array}$ & None \\
\hline 41SS38 & Lithic Scatter & Terrace & Not Reported & Not Reported & Not Reported \\
\hline $41 S S 165$ & Lithic Scatter & Terrace & Unknown Prehistoric & None & None \\
\hline $41 S S 163$ & Lithic Scatter & Terrace & Unknown Prehistoric & None & None \\
\hline $41 S S 145$ & Lithic Scatter & Terrace & Archaic & None & None \\
\hline 41SS54 & Lithic Scatter/Procurement & Hillslope & Unknown Prehistoric & None & None \\
\hline 41SS55 & Lithic Scatter/Procurement & Hillslope & Unknown Prehistoric & None & None \\
\hline 41SS56 & Lithic Scatter/Procurement & Hillslope & Unknown Prehistoric & None & None \\
\hline 41SS58 & Lithic Scatter/Procurement & Hillslope & Unknown Prehistoric & None & None \\
\hline $41 S S 60$ & Lithic Scatter/Procurement & Hilltop & Unknown Prehistoric & None & None \\
\hline 41SS57 & Multicomponent & Hillslope & $\begin{array}{c}\text { Unknown Prehistoric/ } \\
\text { Historic }\end{array}$ & $\begin{array}{c}\text { Glass, Corsicana Brick, } \\
\text { and Nails }\end{array}$ & $\begin{array}{l}\text { Wooden Structures } \\
\text { Outside of ROW }\end{array}$ \\
\hline $41 S S 40$ & Multicomponent & Hillslope & Archaic/Historic & $\begin{array}{c}\text { Gower and Historic } \\
\text { Whiteware }\end{array}$ & Midden \\
\hline $41 S S 79$ & Multicomponent & Terrace & $\begin{array}{c}\text { Unknown Prehistoric/ } \\
\text { Historic }\end{array}$ & None & $\begin{array}{c}\text { Midden and Stone } \\
\text { Wall }\end{array}$ \\
\hline $41 S S 140$ & Multicomponent & Terrace & Late Archaic/Historic & Ensor and Historics & None \\
\hline $41 S S 29$ & Multicomponent & Terrace & Early Archaic-Historic & $\begin{array}{l}\text { Dart and Arrow points } \\
\text { and Historics }\end{array}$ & Middens \\
\hline 41SS41 & Multicomponent & Terrace & $\begin{array}{c}\text { Unknown Prehistoric/ } \\
\text { Historic }\end{array}$ & Historic Ceramics & Spring Facility \\
\hline $41 S S 83$ & Multicomponent & Terrace & $\begin{array}{c}\text { Unknown Prehistoric/ } \\
\text { Historic }\end{array}$ & Historics & $\begin{array}{c}\text { Midden and House } \\
\text { Remains }\end{array}$ \\
\hline
\end{tabular}


Table 7.2. Previously Recorded Sites in the Llano Uplift, continued

\begin{tabular}{|c|c|c|c|c|c|}
\hline Site & Site Type & Landform & Archaeological Periods & Diagnostic Tools & Features \\
\hline 41SS106 & Multicomponent & Terrace & $\begin{array}{c}\text { Archaic/Prehistoric/His- } \\
\text { toric }\end{array}$ & Dart and Arrow points & $\begin{array}{c}\text { Middens and Farm } \\
\text { Structures }\end{array}$ \\
\hline 41SS135 & Multicomponent & Terrace & Late Paleoindian/Historic & $\begin{array}{c}\text { Plainview and Historic } \\
\text { Pottery }\end{array}$ & None \\
\hline 41SS1 & Not Reported & Hillslope & Not Reported & Not Reported & Not Reported \\
\hline 41SS2 & Not Reported & Hillslope & Not Reported & Not Reported & Not Reported \\
\hline $41 S S 9$ & Not Reported & Terrace & Not Reported & Not Reported & Not Reported \\
\hline 41SS67 & Not Reported & Terrace & Not Reported & Not Reported & Not Reported \\
\hline 41SS68 & Not Reported & Terrace & Not Reported & Not Reported & Not Reported \\
\hline $41 S S 127$ & Open Campsite & Floodplain & Paleoindian-Historic & Golondrina and Crockery & None \\
\hline $41 S S 128$ & Open Campsite & Floodplain & Unknown Prehistoric & Dart points & None \\
\hline $41 S S 116$ & Open Campsite & Floodplain & $\begin{array}{c}\text { Late Archaic/Late Paleo- } \\
\text { indian }\end{array}$ & $\begin{array}{c}\text { Plainview }(4) \text { and Archaic } \\
\text { Dart points }(7)\end{array}$ & None \\
\hline 41SS25 & Open Campsite & Floodplain & Not Reported & Scallorn & None \\
\hline 41SS125 & Open Campsite & Floodplain & $\begin{array}{c}\text { Paleoindian/Late Pre- } \\
\text { historic }\end{array}$ & Scallorn and Dart points & None \\
\hline 41SS92 & Open Campsite & Floodplain & Unknown Prehistoric & None & None \\
\hline $41 S S 93$ & Open Campsite & Floodplain & Unknown Prehistoric & None & None \\
\hline $41 S S 49$ & Open Campsite & Floodplain & Unknown Prehistoric & None & Bedrock Mortars \\
\hline 41SS10 & Open Campsite & Hillslope & Archaic & Dart and Arrow points & Not Reported \\
\hline $41 S S 6$ & Open Campsite & Hillslope & Unknown Prehistoric & Meserve and Dart points & None \\
\hline 41SS26 & Open Campsite & Hillslope & Archaic & None & None \\
\hline $41 S S 23$ & Open Campsite & Hillslope & Archaic & Dart points & None \\
\hline 41SS96 & Open Campsite & Hillslope & Late Paleoindian/Archaic & $\begin{array}{c}\text { Angostura and Archaic } \\
\text { Dart points }\end{array}$ & None \\
\hline $41 S S 72$ & Open Campsite & Hillslope & Late Prehistoric & Arrow point Preform & None \\
\hline 41SS78 & Open Campsite & Hillslope & Unknown Prehistoric & None & None \\
\hline
\end{tabular}


Table 7.3. Previously Recorded Sites in the Mesquite Plains

\begin{tabular}{|c|c|c|c|c|c|}
\hline Site & Site Type & Landform & Archaeological Periods & Diagnostic Tools & Features \\
\hline $41 \mathrm{MI} 107$ & Bedrock Mortar Complex & Terrace & Unknown Prehistoric & None & Mortars (70) \\
\hline $41 \mathrm{Ml} 105$ & Isolate & Upland Drainage & Middle Archaic & Nolan & None \\
\hline $41 \mathrm{MI} 74$ & Lithic Procurement & Hillslope & Unknown Prehistoric & None & None \\
\hline $41 \mathrm{MI} 11$ & Lithic Procurement & Hilltop & Unknown Prehistoric & None & One Observed \\
\hline $41 \mathrm{Ml} 12$ & Lithic Procurement & Hilltop & Unknown Prehistoric & None & None \\
\hline $41 \mathrm{MI} 86$ & Lithic Procurement & Hilltop/Slope & Unknown Prehistoric & None & None \\
\hline $41 \mathrm{Ml} 17$ & Lithic Procurement & Terrace & Archaic & Dart Points & None \\
\hline $41 \mathrm{MI} 2$ & Lithic Procurement & Terrace & Unknown Prehistoric & Tortugas (possible) & None \\
\hline $41 \mathrm{MI} 7$ & Lithic Scatter & Floodplain & Archaic & Pedernales; Abasolo & None \\
\hline 41MI91 & Lithic Scatter & Hillslope & Archaic/Late Prehistoric & None & None \\
\hline $41 \mathrm{MI} 19$ & Lithic Scatter/Procurement & Hillslope & Archaic (?) & Dart Point & None \\
\hline $41 \mathrm{MI} 21$ & Lithic Scatter/Procurement & Hillslope & Unknown Prehistoric & None & None \\
\hline $41 \mathrm{MI} 90$ & Multicomponent & Terrace & $\begin{array}{c}\text { Unknown Prehistoric/ } \\
\text { Historic }\end{array}$ & $\begin{array}{c}\text { Glass, Bricks, and } \\
\text { Whiteware }\end{array}$ & Root Cellar \\
\hline $41 S S 73$ & Multicomponent & Terrace & $\begin{array}{c}\text { Unknown Prehistoric/ } \\
\text { Historic }\end{array}$ & Glass and Metal & None \\
\hline $41 \mathrm{MI} 95$ & Not Reported & Hillslope & Not Reported & Not Reported & Not Reported \\
\hline $41 \mathrm{MI} 25$ & Not Reported & Upland Drainage & Not Reported & Not Reported & Not Reported \\
\hline $41 \mathrm{MI} 93$ & Open Campsite & Hillslope & Paleoindian & Clovis & None \\
\hline $41 \mathrm{MI} 70$ & Open Campsite & Hillslope & Late Archaic (?) & Dart points & Possible Hearths \\
\hline $41 \mathrm{MI} 75$ & Open Campsite & Hillslope & Late Prehistoric & Scallorn & None \\
\hline $41 \mathrm{MI} 87$ & Open Campsite & Hillslope & Late/Transitional Archaic & $\begin{array}{c}\text { Pedernales, Ensor, and } \\
\text { Scallorn }\end{array}$ & None \\
\hline $41 \mathrm{MI} 28$ & Open Campsite & Hillslope & $\begin{array}{c}\text { Middle Archaic/Late } \\
\text { Archaic } \\
\end{array}$ & \begin{tabular}{|c|} 
Dart Points and Peder- \\
nales Preform
\end{tabular} & None \\
\hline $41 \mathrm{MI} 68$ & Open Campsite & Hilltop & Middle Archaic & Castroville & Possible Hearths \\
\hline $41 \mathrm{MI} 88$ & Open Campsite & Hilltop & Middle Archaic (?) & Bulverde and Ensor & None \\
\hline $41 \mathrm{MI} 82$ & Open Campsite & Hilltop & $\begin{array}{c}\text { Middle/Transitional } \\
\text { Archaic } \\
\end{array}$ & Kent & Mortar \\
\hline $41 \mathrm{MI} 14$ & Open Campsite & Terrace & Early Archaic & Angostura (2) & None \\
\hline $41 \mathrm{MI} 18$ & Open Campsite & Terrace & Late Archaic & Castroville & None \\
\hline $41 \mathrm{MI} 23$ & Open Campsite & Terrace & Late Archaic & $\begin{array}{l}\text { Castroville and Ensor } \\
\text { (possible) }\end{array}$ & None \\
\hline $41 \mathrm{MI} 24$ & Open Campsite & Terrace & Late Archaic & Marcos & None \\
\hline $41 \mathrm{MI} 22$ & Open Campsite & Terrace & Late Archaic (?) & Castroville (possible) & Hearths (possible) \\
\hline $41 S S 19$ & Open Campsite & Terrace & $\begin{array}{l}\text { Middle Archaic/Neo- } \\
\text { American }\end{array}$ & & \\
\hline $41 \mathrm{MI} 13$ & Open Campsite & Terrace & Unknown Prehistoric & None & None \\
\hline $41 \mathrm{MI} 15$ & Open Campsite & Terrace & Unknown Prehistoric & None & None \\
\hline $41 \mathrm{MI} 16$ & Open Campsite & Terrace & Unknown Prehistoric & None & None \\
\hline $41 \mathrm{MI} 20$ & Open Campsite & Terrace & Unknown Prehistoric & None & None \\
\hline $41 \mathrm{MI} 96$ & Open Campsite & Terrace & Late Archaic & Marcos & Hearths $(7)$ \\
\hline $41 \mathrm{MI} 71$ & Open Campsite & Terrace & Unknown Prehistoric & None & None \\
\hline $41 \mathrm{MI} 103$ & Open Campsite & Terrace & Unknown Prehistoric & None & None \\
\hline $41 S S 74$ & Open Campsite & Terrace & Unknown Prehistoric & None & None \\
\hline $41 \mathrm{MI} 78$ & Open Campsite & Upland Drainage & Unknown Prehistoric & None & Mortar \\
\hline
\end{tabular}


Table 7.3. Previously Recorded Sites in the Mesquite Plains, continued

\begin{tabular}{|c|c|c|c|c|c|}
\hline Site & Site Type & Landform & Archaeological Periods & Diagnostic Tools & Features \\
\hline $41 \mathrm{MI} 73$ & Open Campsite & Upland Drainage & Late Archaic & Montell & None \\
\hline $41 \mathrm{MI} 8$ & Open Campsite with Midden & Floodplain & Late Archaic & Castroville & Midden (1) \\
\hline $41 \mathrm{MI} 83$ & Open Campsite with Midden & Floodplain & Middle Archaic & Pedernales and Kent & Middens and Mortar \\
\hline $41 \mathrm{MI} 92$ & Open Campsite with Midden & Hillslope & Archaic (?) & Pedernales & Midden \\
\hline 41MI106 & Open Campsite with Midden & Hillslope & Middle/Late Archaic & None & Midden \\
\hline $41 \mathrm{MI} 60$ & Open Campsite with Midden & Hillslope & Late Archaic & Ensor & Hearths and Midden \\
\hline $41 \mathrm{MI} 77$ & Open Campsite with Midden & Hillslope & Late Prehistoric & Scallorn & Midden \\
\hline $41 \mathrm{MI} 69$ & Open Campsite with Midden & Hillslope & Middle Archaic (?) & None & Sandstone Midden \\
\hline $41 \mathrm{MI} 104$ & Open Campsite with Midden & Hillslope & Middle/Late Archaic & None & Sandstone Midden \\
\hline $41 \mathrm{MI} 76$ & Open Campsite with Midden & Hillslope & Unknown Prehistoric & None & Midden and Mortars \\
\hline $41 \mathrm{MI} 66$ & Open Campsite with Midden & Hilltop & Archaic/Late Prehistoric & Dart and Arrow points & $\begin{array}{c}\text { Midden and Bedrock } \\
\text { Mortars }\end{array}$ \\
\hline $41 \mathrm{MI} 89$ & Open Campsite with Midden & Hilltop & Archaic (?) & None & Midden \\
\hline $41 \mathrm{MI} 27$ & Open Campsite with Midden & Hilltop & $\begin{array}{c}\text { Late Archaic/Late Pre- } \\
\text { historic }\end{array}$ & $\begin{array}{l}\text { Darl, Fairland, and Ar- } \\
\text { row point }\end{array}$ & Midden \\
\hline $41 \mathrm{MI} 84$ & Open Campsite with Midden & Hilltop & Middle Archaic (?) & None & Sandstone Midden \\
\hline $41 \mathrm{MI} 10$ & Open Campsite with Midden & Hilltop/Slope & $\begin{array}{c}\text { Late Archaic/Late Pre- } \\
\text { historic }\end{array}$ & Dart and Arrow points & Midden \\
\hline $41 \mathrm{MI} 94$ & Open Campsite with Midden & Terrace & $\begin{array}{l}\text { Middle Archaic/Early } \\
\text { Prehistoric }\end{array}$ & $\begin{array}{c}\text { Pedernales(2), Travis, } \\
\text { and Granbury }\end{array}$ & Midden \\
\hline $41 \mathrm{MI} 85$ & Open Campsite with Midden & Terrace & Middle Archaic (?) & None & Midden \\
\hline $41 \mathrm{MI} 9$ & Open Campsite with Midden & Terrace & $\begin{array}{c}\text { Late Archaic/Late Pre- } \\
\text { historic }\end{array}$ & Dart and Arrow points & Middens/Hearths \\
\hline $41 \mathrm{MI} 67$ & Open Campsite with Midden & Terrace & Middle Archaic & Travis & Midden \\
\hline $41 \mathrm{MI} 79$ & Open Campsite with Midden & Upland Drainage & Unknown Prehistoric & None & Midden \\
\hline $41 \mathrm{MI} 80$ & Open Campsite with Midden & Upland Drainage & Archaic & Martindale (2) & Midden \\
\hline
\end{tabular}

as they were the only sites within the research area that have been investigated beyond the recordation stage and for which the information has been made publicly available. Although a couple of sites were just surface collected and not really tested in the modern sense, the term "tested sites" is used here to distinguish them from previously recorded sites for which no further information is available. Each of the four sites used in the analysis is described below, and a summary is presented in Table 7.4.

\section{SUMmaRY of TESTED Sites Found WITHIN THE TRI-COUNTY AREA}

Due to the modest modern growth and development in San Saba, Mills, and Lampasas Counties, there have been very limited archaeological investigations stemming from cultural resource compliance. The "gray literature" generated from these investigations, which are generally housed at the THC, concentrate on survey-level endeavors; no literature pertaining to testing or data recovery investigations was located during a search of these records. A search of other potential sources for literature pertaining to archaeological investigations of the tri-county area found several reports published in the Bulletin of the Texas Archeological Society. These reports described investigations at specific archaeological sites in San Saba and Lampasas Counties, and are summarized below. In addition, a site in San Saba County was excavated through a series of summer field schools (1993-1996) sponsored by Texas Tech University. These excavations have been the source material for several theses written by graduate students, one of which will be profiled below. 


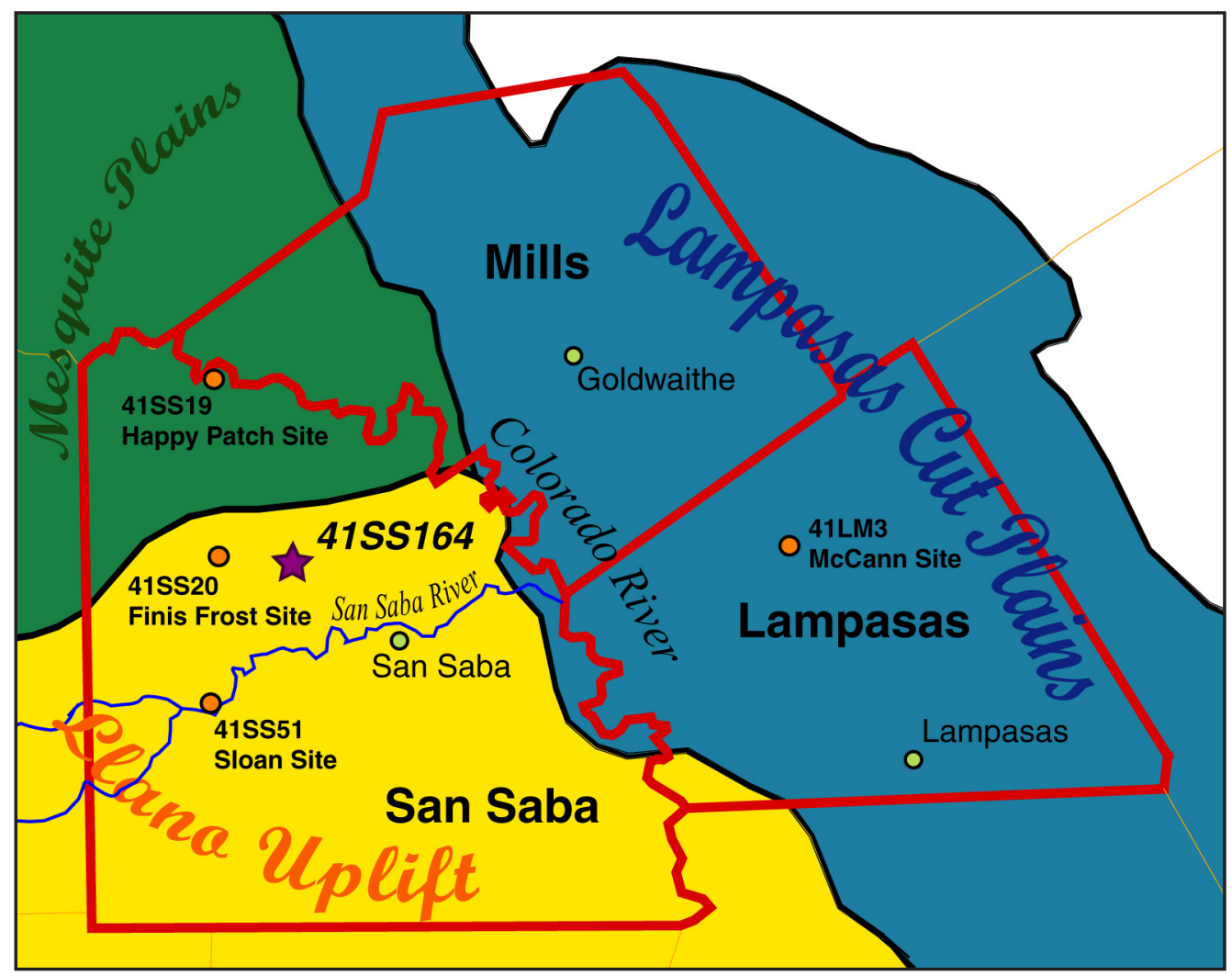

Figure 7.3. Location of tested archaeological sites in the tri-county research area.

\section{Happy Patch Site (41SS19)}

The Happy Patch site (41SS19) is located in San Saba County on a terrace overlooking the Colorado River, about 14.3 miles north-northwest of $41 \mathrm{SS} 164$ (Green 1971). The Happy Patch site lies along the edge of a terrace within an inside bend of the Colorado River and extends away from the river about $80-100 \mathrm{~m}$ into an agricultural field. The leading edge of the level terrace does not follow the current curve of the river, but is oriented more linearly in a north-south orientation. The site is approximately 40 acres in size or roughly $1,100 \mathrm{~m}$ long by at least $150 \mathrm{~m}$ wide. At the time of its documentation, a large quantity of prehistoric cultural material was visible on the surface of the terrace, including at least eight shell accumulations, but few lithic materials and no burned rock features were found. The steep cut bank leading down to the river, although over $1 \mathrm{~m}$ thick in places, did not reveal any subsurface burned rock middens or other features (Green 1971:323). The site is located on privately owned land to which the archaeologists had access in 1971. It had been extensively disturbed by earth moving and much of the prehistoric material had been moved around, but two shell accumulations appeared to be intact. Scattered burned rock was located near a shell accumulation that may have once been a burned rock hearth, but the rocks were too disturbed to provide any meaningful information. The majority of the artifacts recovered were found on the surface, but some subsurface excavations were conducted to determine the depth of deposits. As the site was investigated through the courtesy of the landowners and not through any regulatory compliance, no determinations of eligibility for listing on the NRHP or for designation as an SAL were made.

The archaeological investigation of the site revealed that the bulk of the cultural material was located on the leading edge of the terrace overlooking the Colorado River. The shell accumulations were observed to be very dense and easily defined. Of the two completely intact shell middens, one was about 4-x-6 m, the other was 2-x-4 $\mathrm{m}$, and both extended only about $20 \mathrm{~cm}$ below the surface. A few pieces of debitage were found in the vicinity of these middens. The other six shell middens were found to be disturbed 
Table 7.4. Summary of Tested Sites Selected for Study

\begin{tabular}{|c|c|c|c|c|c|}
\hline Site & $\begin{array}{c}\text { Natural } \\
\text { Subregion }\end{array}$ & Landform & Features & Diagnostic Tools & $\begin{array}{c}\text { Size } \\
\text { (acres) }\end{array}$ \\
\hline $\begin{array}{l}\text { 41SS19: } \\
\text { Happy } \\
\text { Patch Site }\end{array}$ & $\begin{array}{l}\text { Mesquite } \\
\text { Plains }\end{array}$ & $\begin{array}{l}\text { Terrace of Colorado } \\
\text { River }\end{array}$ & $\begin{array}{l}8 \text { shell accumula- } \\
\text { tions and pos- } \\
\text { sible hearth }\end{array}$ & $\begin{array}{l}\text { Scallorn, Fresno, Frio, Marcos, Yar- } \\
\text { brough, and Pedernales }\end{array}$ & 40 \\
\hline $\begin{array}{l}\text { 41SS20; } \\
\text { Finis Frost } \\
\text { Site }\end{array}$ & Llano Uplift & $\begin{array}{l}\text { Terrace of Richland } \\
\text { Springs Creek }\end{array}$ & None & $\begin{array}{l}\text { Perdiz, Fresno or Fresno-vari- } \\
\text { ant, Harrell or Washita, Leon Plain } \\
\text { ceramics }\end{array}$ & 4 \\
\hline $\begin{array}{l}\text { 41SS51; } \\
\text { Sloan Site }\end{array}$ & Llano Uplift & $\begin{array}{l}\text { Terrace of San Saba } \\
\text { River }\end{array}$ & 1 midden & $\begin{array}{l}\text { Darl, Early Stemmed, Early Triangu- } \\
\text { lar, Ensor, Gower, Marcos, Montell, } \\
\text { Pedernales, Perdiz, Scallorn, Early } \\
\text { Archaic multi-notched tool }\end{array}$ & 0.35 \\
\hline $\begin{array}{l}\text { 41LM3; } \\
\text { McCann } \\
\text { Site }\end{array}$ & $\begin{array}{l}\text { Lampasas } \\
\text { Cut Plains }\end{array}$ & $\begin{array}{l}\text { Upland Drainage of } \\
\text { Bee Cave Creek }\end{array}$ & $\begin{array}{l}1 \text { midden, } \\
5 \text { hearths, } \\
2 \text { burials }\end{array}$ & $\begin{array}{l}\text { Scallorn, Young, Alba, Fresno, } \\
\text { Perdiz, Darl, Ensor, Yarbrough, Mon- } \\
\text { tell, Marcos, Frio, Castroville, Wells, } \\
\text { Marshall, Lange, Bulverde, Travis, } \\
\text { Nolan, Pedernales, Martindale, Tor- } \\
\text { tugas, Kinney, Abasolo, Gower-like, } \\
\text { Plainview-like, Angostura-like }\end{array}$ & 18.5 \\
\hline $41 S S 164$ & Llano Uplift & $\begin{array}{l}\text { Terrace of Richland } \\
\text { Springs Creek }\end{array}$ & 1 midden & Pandale and Fairland & 0.09 \\
\hline
\end{tabular}

to varying degrees; the bulk of the recovered cultural material was found within the vicinity of one of these middens, and one Fresno dart point was found nestled within the shell of another midden to the north. The other shell accumulations did not contain any diagnostic material (Green 1971:323-324). The researchers determined the site was occupied from the Middle or Late Archaic through to the Neo-American (Late Prehistoric) periods. These occupation dates were derived from the diagnostic points found at the site (Scallorn, Fresno, Frio, Marcos, Yarbrough, and Pedernales), and the chronology developed by Johnson et al. (1962) and Sorrow et al. (1967). In addition to the projectile points, bifaces, unifaces, a perforator, a graver, two manos, and blades, were also recovered. Unfortunately, no radiocarbon samples were taken and no absolute dates were produced for the site.

Although speculative, the author does offer some interpretation of the Happy Patch site (Green 1971:332-333). The author writes that the evidence suggests that the site was the location of a small campsite intermittently occupied by small groups of people, possibly from neighboring sites a short distance upstream that do have large burned rock middens and indicate long-term occupation (based on personal observation $)^{2}$. The area may have been a stop for hunter-gatherer groups to exploit the mussels in the Colorado River, which was most likely their primary activity. Manos at the site indicate food-gathering and milling operations in addition to hunting.

\section{Finis Frost Site (41SS20)}

The Finis Frost site (41SS20) is located in San Saba County on a terrace overlooking Richland Springs Creek, about 5.5 miles west of 41SS164 (Green and Hester 1973). The Finis Frost site lies along the surface of a low terrace on the southern bank of Richland Springs Creek, bounded by the creek bank to the north and two intermittent tributaries supplied by springs to the south and west. Limestone uplands approach to within 75-100 $\mathrm{m}$ of the site on the east side. The site is approximately 4 acres in size with a roughly circular shape. A large quantity of prehistoric cultural material was visible on the surface of the terrace, with the densest concentration on the east-southeast part of the site covering an 80-x-20$\mathrm{m}$ area. No discernable features were found on the

\footnotetext{
${ }^{2}$ No additional formally recorded sites are in the area suggested by Green (1971) and no additional information on the middens is available.
} 
site surface (Green and Hester 1973:72). The site is located on privately owned land to which the archaeologists had access in 1970 and 1971. Numerous lithic artifacts were collected by the archaeologists, and some of the exposed faunal material was also recovered. Additional collections were held by several people, and the recording archaeologists had only enough access to portions of the collection to record general characteristics. The site had been moderately disturbed by plowing and all of the artifacts were recovered from the ground; no subsurface excavations were conducted. As the site was investigated through the courtesy of the landowners and not through any regulatory compliance, no determinations of eligibility for listing on the NRHP or for designation as an SAL were made.

Despite the lack of subsurface excavations at the Finis Frost site, the sheer quantity of artifacts recovered from the surface is impressive. The authors used the typology developed by Suhm et al. (1954) and Bell (1958) to classify the diagnostic tools. Of the diagnostic projectile points, 27 Perdiz points, three Fresno or Fresno-variants, and one Harrell or Washita point were recovered. In addition, 17 ceramic pieces conforming to the Leon Plain type were recovered from the site and are in a private collection. Most were bone tempered; although one appeared to be tempered with grog and two others contained a calcareous material (Green and Hester 1973:81). Four relatively complete four-beveled bifaces, two double-pointed bifaces without the beveling, and three oval bifaces were recovered, as well as several asymmetrical bifaces, choppers, perforators, unifaces, scrapers, cores, flake blades, and modified flakes. Sandstone manos and metates, chert or quartzite hammerstones, and quartzite polishing stones were also observed at the site. Large quantities of bison bone, as well as deer, turtle, and bobcat were collected from the site surface along with the other artifacts. The researchers determined the site was occupied during the Late Prehistoric Toyah phase based on the artifacts recovered (ca. A.D. 1250-1560; using the chronology of Jelks [1962]; Shafer [1971]; and Hester [1971]).

In attempting to tie in the Finis Frost site into what is known about Toyah phase occupations in central Texas, the authors point out that the artifacts recovered represent a campsite of this period, and the inclusion of bison bone and a large number of scrapers indicate hide-working activities at the site. In addition, the manos and metates found at the site indicate plant processing, and may signal maize horticultural practices, which were conducted in favorable locals such at the Finis Frost site area (Green and Hester 1973:85). The authors conclude that the site was primarily used as a seasonal bison hunting encampment, and may have been a semi-sedentary occupation area. The Finis Frost site was at the time the only known Toyah phase occupation site, which was deemed significant by the researchers. Other possible occupation surfaces underneath the surfacelevel Toyah phase zone were not discussed.

\section{SloAn Site (41SS51)}

The Sloan site (41SS51) is located in San Saba County on a northern terrace overlooking the San Saba River, about 10.9 miles south-southwest of 41SS164 (Butler 2006). The Sloan site lies on a second terrace of a long, low floodplain deposit of the San Saba River 200 m north of the river's left bank, and about $4 \mathrm{~km}$ downstream from the confluence of Brady Creek. An annular burned rock midden is the most prominent feature of the site. The surface exposure of the midden deposit is oval shaped, about $16 \times 12 \mathrm{~m}$ in size and covering an area of about 170 $\mathrm{m}^{2}$, and the site as a whole is approximately 0.35 acres in size, or roughly $40 \mathrm{~m}$ long by at least $35 \mathrm{~m}$ wide. Some prehistoric cultural material was visible on the surface of the terrace along with the burned rock midden at the time of recordation. A steep cut bank leading down to a ravine on the west side of the site also revealed over $3 \mathrm{~m}$ of cultural deposits (Butler 2006:11). The site is located on privately owned land to which archaeologist from Texas Tech University had access from 1993-1996. It had been moderately disturbed by mesquite brush removal and a dirt road, but the surface alterations did not affect more than the top $3 \mathrm{~cm}$ of subsurface deposits. The archaeologists excavated portions of the site up to $2.1 \mathrm{~m}$ below the surface of the terrace and did not encounter sterile deposits. However, the quantities of artifacts decreased significantly towards the bottom of the excavation units. As the site was investigated through the courtesy of the landowners and not through any regulatory compliance, no determina- 
tions of eligibility for listing on the NRHP or for designation as an SAL were made.

The archaeological investigations of the site established a lower, middle, and upper horizon across the site through an analysis of the internal stratigraphy. The estimated ages for these horizons, based on diagnostic projectile points and corresponding artifacts, are Early Archaic (8,000-4,500 B.P.) for the lower horizon, Middle to Late Archaic (4,500-1,300 в.P.) for the middle horizon, and Late Prehistoric (1,300-500 B.P.) for the upper horizon (Butler 2006:25). The chronology developed by Turner and Hester (2002) and Collins (1998) were used to define the ages of the diagnostic projectile points and thus the periods of occupation. Unfortunately, no radiocarbon samples were taken and no absolute dates were produced for the site.

The artifacts recovered from the lower horizon indicated vertical mixing. The lower horizon only contained Late Archaic projectile points (three Darl points), and all of the identified Early Archaic diagnostic artifacts (Gower, Early Triangular, and Early Archaic multi-notched uniface) were recovered from either a backhoe trench with no vertical provenience or above and below the identified lower horizon. The Middle Archaic was represented in the middle horizon by one Pedernales point, but the Late Archaic was better expressed within this horizon in the form of four Darl points, two Ensor points, and one Montell point. The burned rock midden primarily occupied the middle horizon; the two Ensor points were recovered within the midden, providing the feature with a utilization date range at least in the Late Archaic. Artifactual evidence in the upper horizon consisted of Perdiz points and Leon Plain ceramics, signifying a Late Prehistoric occupation. While the Archaic components below the upper horizon exhibited some vertical mixing, the Late Prehistoric deposits appeared to be more intact. A Scallorn point was found in the upper levels of the middle horizon within the burned rock midden (possibly indicating a Late Prehistoric use of the midden), but otherwise no Late Prehistoric artifacts were found outside of their stratigraphic sequence (Butler 2006:25-29).

About 28 recognizable projectile points were recovered from excavations at the Sloan site, including seven Darl, one Early Stemmed, one Early Triangular, four Ensor, one Gower, one Marcos, one Montell, one Pedernales, two Perdiz, one Scallorn, and eight unidentified points. In addition, possible bifacial knives, scrapers, preforms, perforators or drills, unifaces, an Early Archaic multi-notched tool, cores and core fragments, debitage, manos, and prehistoric ceramics were found and recovered from the site. Faunal remains, including deer, bison, cottontail, beaver, unknown fish species, mussels, and aquatic and terrestrial snails were also recovered from the excavations. Through a preliminary examination, it was observed that bone and mussel shell have an inverse relationship with snail shells, i.e., one increased while the other decreased, and vice versa. The researchers speculated that snail processing was used as an alternative food source during droughts or other hard times (Butler 2006:101-102).

The researchers compared the Sloan site with the sites profiled in Black et al. (1997) to the west, specifically the Corn Creek sites (41MK8 and 41MK9) and the Honey Creek site (41MS32). The WilsonLeonard site (41WM235) and the Mustang Branch site (41HY209) to the southeast were also reviewed for any similarities with the Sloan site. The most apparent similarities included the important Late Prehistoric aspect found at each site, a location near streams or rivers, and the habitual mixing of older burning events with newer ones, which caused some confusion with site stratigraphy. Alternatively, differences in geology, resource availability and utilization, and slightly varying climates were hypothesized as the most likely contributors to the major differences in the site components. At the Sloan Site, the stratigraphic mixing was not extensive enough to destroy the general chronology, which was attributed to periodic flooding of the San Saba River and upland sheetwash that quickly separated cultural sequences and helped to preserve the integrity of the site (Butler 2006:112-113).

\section{McCann Site (41LM3)}

The McCann site (41LM3) is located in Lampasas County at the top of an unnamed spring-fed draw of Bee Cave Creek, about 31.4 miles east of 41SS164 (Preston 1969). The McCann site lies on two level 
surfaces straddling the draw almost at the top of an upland mesa; the draw exits the site area to the east, curves northward into a valley, and empties into Bee Cave Creek about $2.6 \mathrm{~km}$ from the site. The site location affords an excellent view of the valley below. The site's size varies in the literature, depending on what aspects are included. Preston (1969:168) describes the area as having a total of six "sites:" five sites on shallow soil with a large fire pit or hearth surrounded by "camp rubble," and the sixth, which he calls the McCann site, contains a stratified buried midden deposit in the center of the other "sites." He describes the McCann site in this scenario as 125 feet long by 40 feet wide ( $38 \mathrm{x}$ $12 \mathrm{~m})$. However, the site files at TARL indicate the site is more like $100 \times 200$ feet $(30.4 \times 61 \mathrm{~m})$ in size, and mapped site area on the Atlas is more like 500 x $150 \mathrm{~m}$. Thus, at its largest dimension, which most likely includes all six "sites," the McCann site is about 18.5 acres. As mentioned above, the McCann site (which for the purposes here will comprise the most inclusive description) contains prehistoric cultural material on the surface, with the densest concentrations surrounding five burned rock hearths and a large burned rock midden in the center of the draw. The site is located on privately owned land to which the archaeologists had access.

The five campsites surrounding the large burned rock midden were probed with shovel tests, but all were found to be located on shallow soil and no subsurface artifacts were located. The central subsurface midden is bounded by the stream bed to the south and a bluff to the north, constricting the site area and creating a "situation like that of a rockshelter where later residents were forced to camp on top of earlier debris" (Preston 1969:168-9). The entire central midden was excavated in a series of 5-foot squares and the natural stratigraphy was used for vertical control. Zone I, the uppermost zone, had a mean thickness of 18 inches $(25.4 \mathrm{~cm})$ and a matrix of black topsoil with a large quantity of ash. Very little burned rock was seen in this zone. Zone II, below Zone I, had a mean thickness of 30 inches $(76.2 \mathrm{~cm})$ and a matrix of gray-white ash and cracked limestone. No pattern in the limestone was seen. Zone III, the lowest zone, measured about 18 inches thick $(25.4 \mathrm{~cm})$ and was much smaller in size then the upper zones, with dark brown soil and only small amounts of ash and burned rock. The TARL files indicate that two large "fire pits" underneath the midden were found at the McCann site, which would indicate that another occupation surface was present in Zone III that is not hinted at in the description of that zone in the article. In addition, the site files mention two burials were excavated at the site, which are not described at all in the article (in fact, the article says there are no burials; Preston 1969:173) and only briefly in the files.

The quantity of artifacts recovered from the excavated midden at the McCann site is large, especially for such a small area. The authors used the typology developed by Suhm et al. (1954) and Sorrow et al. (1967) to classify the diagnostic tools. A listing of the identified projectile points found by zone is presented in Table 7.5. ${ }^{3}$ The researchers remarked on the presence of Early Archaic points (Ensor, Darl, and Yarbrough) and Late Archaic points (Bulverde and Pedernales $)^{4}$ in the same levels in Zone I, the change in projectile points types in Zone II with Montell, Marcos, Frio, Castroville, Wells, and Marshall points slowly replaced by Travis and Nolan points with increased depth, the presence of "Paleo" points below the Archaic points in Zone III, and the number of complete points throughout the site. Flakes were virtually absent in Zone III, even though large quantities of incomplete bifaces and projectile points were present, indicating a change in activities between the occupations represented by Zone III than Zones I and II. Table 7.6 shows the list of chipped stone tools found by zone at the site, including the very rare "corner tang" bifaces and a long "spear" point. Finally, the remaining artifacts described from the site include numerous mano and metate fragments found in Zones I and II, one mano fragment in the upper portion of Zone III, atlatl weights, bone tools (awls?) from the upper 24 inches, a stone gorget,

\footnotetext{
${ }^{3}$ Points with few representatives are not included in this list, including Palmillas, Kent, Uvalde, Fairland, Edgewood, and Williams. Preston (1969:174) viewed the addition of these types would overly complicate the typology.

${ }^{4}$ The assignment of Ensor and Darl points to the Early Archaic and the Pedernales point to the Late Archaic were made by the authors of the report, which has been faithfully reiterated here with no additional commentary.
} 
Table 7.5. Numbers of Identified Projectile Point Types Recovered from the McCann Site

\begin{tabular}{|c|c|c|c|c|c|c|c|c|c|c|c|c|c|}
\hline \multirow[b]{2}{*}{ Depth } & \multirow[b]{2}{*}{ Surface } & \multicolumn{3}{|c|}{ Zone I (in) } & \multicolumn{5}{|c|}{ Zone II (in) } & \multicolumn{3}{|c|}{ Zone III (in) } & \multirow[b]{2}{*}{ Total } \\
\hline & & $0-6$ & $6-12$ & $12-18$ & $18-24$ & $24-30$ & $30-36$ & $36-42$ & $42-28$ & $48-54$ & $54-60$ & $60-66$ & \\
\hline Scallorn & 15 & & & & & & & & & & & & 15 \\
\hline Young & 3 & & & & & & & & & & & & 3 \\
\hline Alba & 1 & & & & & & & & & & & & 1 \\
\hline Fresno & 1 & & & & & & & & & & & & 1 \\
\hline Perdiz & 1 & & & & & & & & & & & & 1 \\
\hline Darl & & 15 & 4 & 4 & & & & & & & & & 23 \\
\hline Ensor & & 18 & 24 & 8 & & & & & & & & & 50 \\
\hline Yarbrough & & 6 & 5 & 11 & & & & & & & & & 22 \\
\hline Montell & & 26 & 25 & 14 & 8 & 8 & 6 & & & & & & 87 \\
\hline Marcos & & 6 & 7 & 5 & 3 & 2 & 1 & & & & & & 24 \\
\hline Frio & & 13 & 15 & 9 & 12 & 2 & 4 & 1 & & & & & 56 \\
\hline Castroville & & 18 & 17 & 19 & 14 & 6 & 6 & 4 & & & & & 84 \\
\hline Wells & & 8 & 2 & 3 & 5 & 5 & 1 & 2 & & & & & 26 \\
\hline Marshall & & 9 & 19 & 9 & 4 & 8 & 7 & 13 & & & & & 69 \\
\hline Lange & & 1 & 5 & 4 & 2 & 4 & 4 & 5 & 2 & & & & 27 \\
\hline Bulverde & & 5 & 12 & 6 & 9 & 15 & 32 & 46 & 110 & 28 & & & 263 \\
\hline Travis & & 2 & 3 & 2 & 6 & 8 & 5 & 17 & 18 & 47 & & & 108 \\
\hline Nolan & & 1 & 1 & 2 & 4 & 5 & 6 & 9 & 15 & 80 & & & 123 \\
\hline Pedernales & & 87 & 108 & 93 & 84 & 56 & 59 & 46 & 48 & 16 & 12 & 10 & 619 \\
\hline Martindale & & & 1 & & & 1 & 1 & 1 & 1 & 2 & 1 & 1 & 9 \\
\hline Tortugas & & & & 2 & 2 & & 2 & 2 & 5 & & & & 13 \\
\hline Kinney & & & & & & & 3 & 2 & 2 & & & & 7 \\
\hline Abasolo & & & & & & & 1 & 3 & 1 & 2 & 2 & & 9 \\
\hline Gower-like & & & & & & & & & & 2 & 1 & & 3 \\
\hline Plainview-like & & & & & & & & & & 1 & 3 & 1 & 5 \\
\hline Angostura-like & & & & & & & & & & & 2 & & 2 \\
\hline Unclassified & & & & & & & & & & & & 1 & 1 \\
\hline Total & 21 & 215 & 248 & 191 & 153 & 120 & 138 & 151 & 202 & 178 & 21 & 13 & 1651 \\
\hline
\end{tabular}

\section{Selected Research on Burned Rock} MiddenS

and a bone bead. The observations of the researchers based on this assemblage is that a higher frequency of foliated side scrapers are present in Zone II, more end-scrapers, drills and notches are present in Zone I, and the overall tool size was reduced through the years. The authors conclude that the site was primarily used as a seasonal base camp for various types of hunting and plant processing activities. They are not clear as to the significance of the large number of bifaces or the large numbers of complete and serviceable projectile points discarded at the site, citing a possible trade related or spiritual reason for the action (Preston 1969:192).
The broader research undertaken with this report is to look at unique site characteristics at the confluence of the Mesquite Plain within the Rolling Plains, the Lampasas Cut Plain of the Edwards Plateau, and the Llano Uplift physiographic subregions. Suffering from a lack of detailed research in the immediate area, the amount of previous investigations is minimal at best. The previously tested sites in the tri-county area lend a limited understanding of prehistoric cultural traits specific to this area. The main characteristic of site 41SS164 is its burned rock features, more specifically a burned rock sheet midden (Feature 2) 
Table 7.6. Numbers of Identified Chipped Stone Tools Recovered from the McCann Site

\begin{tabular}{|c|c|c|c|c|c|c|c|c|c|c|c|c|}
\hline \multirow[b]{2}{*}{ Depth } & \multicolumn{3}{|c|}{ Zone I (in) } & \multicolumn{5}{|c|}{ Zone II (in) } & \multicolumn{3}{|c|}{ Zone III (in) } & \multirow[b]{2}{*}{ Total } \\
\hline & $0-6$ & $6-12$ & $12-18$ & $18-24$ & $24-30$ & $30-36$ & $36-42$ & $42-28$ & $48-54$ & $54-60$ & $60-66$ & \\
\hline Nosed Scraper & 1 & & & & & 1 & & & & & & 2 \\
\hline End-scraper & 17 & 14 & 12 & 7 & 3 & 4 & 1 & & & & & 58 \\
\hline Side Scraper & 3 & 3 & 6 & 7 & 3 & 2 & 3 & 1 & & & & 28 \\
\hline Side Scraper (2 sides) & 3 & 5 & 5 & 2 & 2 & & 2 & 1 & & & & 20 \\
\hline Side Scraper Oblique & 1 & 1 & 2 & 1 & 2 & & & & & & & 7 \\
\hline Site Scraper Transverse & 1 & & & 1 & & 1 & 1 & & & & & 4 \\
\hline Side Scraper Dejete & & & 2 & & & & & & & & & 2 \\
\hline Side Scraper Concave & 2 & 3 & 2 & 1 & & 3 & & & & & & 11 \\
\hline End-side Scraper & 3 & 8 & 2 & 6 & 2 & 1 & & & & & & 22 \\
\hline Scrapers Diverse & 3 & 11 & 5 & 2 & & 1 & & & & & & 22 \\
\hline Denticulate & 3 & 5 & 1 & 5 & 1 & 1 & 1 & & & & & 17 \\
\hline Notch & 2 & 2 & 1 & & 1 & & & & & & & 6 \\
\hline Burin & 3 & 3 & 4 & 2 & 1 & 1 & 1 & & & 1 & & 16 \\
\hline Graver & 3 & 2 & 2 & 2 & 1 & 1 & & & & & & 11 \\
\hline Unfinished Proj. Point & 2 & 5 & 1 & & & & & & & & & 8 \\
\hline Preform & 23 & 27 & 16 & 12 & 10 & 15 & 18 & 3 & & & & 124 \\
\hline Thinned Biface & 21 & 49 & 48 & 29 & 29 & 25 & 29 & 10 & 3 & 1 & & 244 \\
\hline Foliate & 5 & 6 & 16 & 8 & 11 & 9 & 4 & 6 & & 1 & & 66 \\
\hline Drill & 10 & 5 & 10 & 4 & & & & & & & & 29 \\
\hline Plano Convex Biface & & & 1 & 1 & & & 1 & & & & & 3 \\
\hline Clear Fork Gouge & 1 & 1 & 1 & & & & & 1 & & & & 4 \\
\hline Corner Tang Knife & & 1 & 2 & 1 & & & & & & & & 4 \\
\hline Truncation & 3 & & & & & & & & & & & 3 \\
\hline Retouched Flake & 7 & 4 & 6 & 14 & 8 & 4 & 1 & 2 & & 1 & & 47 \\
\hline Varia & & 3 & 4 & & & & & & & & & 7 \\
\hline$A x$ & & & 1 & & & & & & & & & 1 \\
\hline Total & 117 & 158 & 150 & 105 & 74 & 69 & 62 & 24 & 3 & 4 & 0 & 766 \\
\hline
\end{tabular}

revealed within the intact sedimentary deposits; thus, a look at significant studies in the region concerning burned rock features was mandatory to understand feature morphology and technology and, hopefully, shed light on the possible cultural processes that could be inferred at site $41 \mathrm{SS} 164$.

The decision to choose San Saba, Mills, and Lampasas Counties as the research area is due to their location at the confluence of the Mesquite Plain, Lampasas Cut Plain, and the Llano Uplift natural subregions. As such, this analysis began with compiling data within the research area, and was able to obtain the data sets for the analysis of previously recorded sites and "tested" sites within the research area. However, information regarding detailed inves- tigations of burned rock middens was non-existent within the tri-county research area. Thankfully, three reports in close vicinity to the tri-county research area have extensive investigations on burned rock features. These reports included investigations on Fort Hood military reservation (Trierweiler 1996), Camp Bowie Texas National Guard base (Mauldin et al. 2003), and four sites on the Greater Edwards Plateau (Black et al. 1997) (Figure 7.4). Thus, these investigations were used to better contextualize the burned rock features at 41SS164. The following is a summary of the three investigations with particular attention to the burned rock feature studies. 


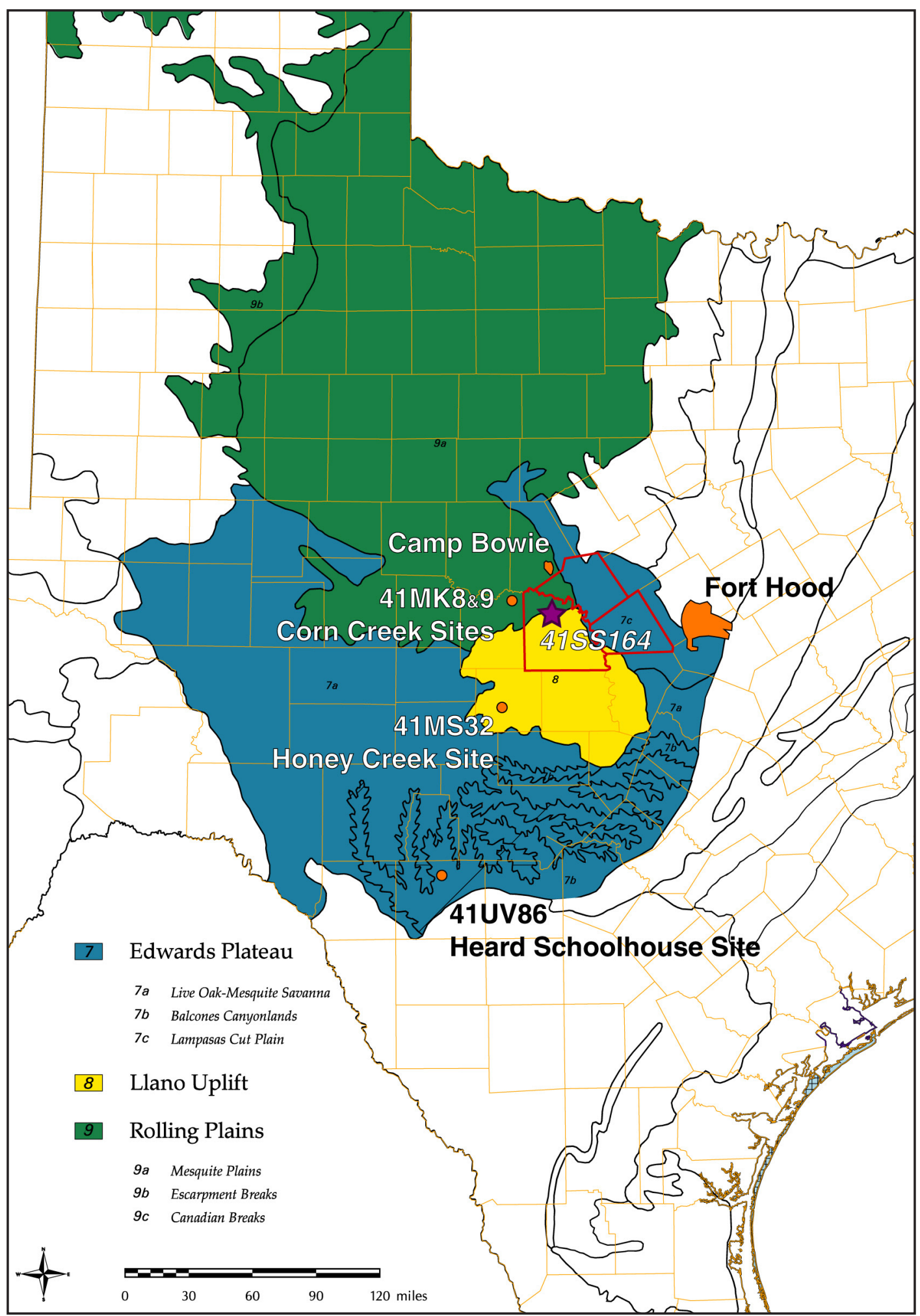

Figure 7.4. Select locations where previous research has been conducted on burned rock middens. 


\section{FORT HOOD}

Fort Hood military reservation is located in northwestern Bell and southeastern Coryell Counties, adjacent to the city of Killeen in central Texas. The military base encompasses 217,337 acres of dissected landscape characteristic of the eastern margins of the Edwards Plateau. With the fort lying a few miles west of the Balcones Fault, the landscape is a rolling, wooded terrain marked by two distinct, flat to gently rolling upland surfaces dotted with numerous springs and seeps, and the stream network they feed (Trierweiler 1994). Hydrologically, the base is dominated by the watershed of Cowhouse Creek, which accounts for more than half of the base area. The creek flows into the Leon River east of the base at the present location of Belton Lake.

Prior to the development of the Fort Hood archaeological program with the hiring of a staff archaeologist in 1977, the unofficial Fort Hood Archeological Society began recording sites throughout the base starting in the late 1960s (Trierweiler 1994). After 1977, under subcontract to Science Applications, Inc., the base was inventoried for surficial sites by Southern Methodist University, then the University of Texas at Austin, and finally by Texas A\&M University. By 1991, 2,090 archaeological sites had been recorded with 30 sites considered eligible for listing on the NRHP and 1,787 sites with a "possibly eligible" or "insufficient data" designation (Trierweiler 1994). Between 1991 and 1993, 571 prehistoric sites were reevaluated by TRC Mariah Associates, Inc., because of their location in areas proposed for military operations (Trierweiler 1994). Fifty-seven of those sites were tested in 1993 (Abbott and Trierweiler 1995), and an additional 56 sites in 1994 and 1995 (Trierweiler 1996). Besides the main goal of site eligibility determination, three specialized studies were conducted. These included the development of a synthetic research design, the study of chert patination and burned rock mound chronology, and the archaeological and ethnological documentation of the Leon River Medicine Wheel. Of special interest to the regional analysis for site $41 \mathrm{SS} 164$ was 1) developing a burned rock mound chronology using the results of the burned rock features investigated throughout the study area and 2) refining the typology of burned rock features by distinguishing between mounds and middens (Trierweiler 1996).

The main type of features observed during the Fort Hood investigations consisted of thermal features composed of burned rock, ash, and/or burned earth (Trierweiler 1996). The study elaborates on the distinction between burned rock feature varieties with the definition of burned rock mounds, burned rock middens, burned rock concentrations, and burned rock pavements. Burned rock mounds are defined as an accumulation of burned rock exhibiting discernable relief above the ground surface and having a fairly regular circular or oval shape in plan view (Trierweiler 1996:582). The two distinct types consist of annular burned rock mounds, which possess a centralized depression, and domed burned rock mounds which lack a central depression (Trierweiler 1996).

In contrast to burned rock mounds, burned rock middens are defined as relatively thick, amorphous deposits of buried burned rock that do not exhibit significant relief and vary greatly in shape and size (Trierweiler 1996). The features identified as burned rock middens during the Fort Hood investigations typically exhibited a dense concentration of burned rocks within a very dark, organic-rich, and fine matrix. In addition, these features had a higher frequency of lithic tools, debitage, and ecofacts as compared to the burned rock mounds (Trierweiler 1996).

Additional burned rock features recognized during the Fort Hood investigations included burned rock concentrations and burned rock pavements. Burned rock concentrations are a relatively shallow, amorphous grouping of burned rocks, typically 1-2 clasts thick, located on the surface of a buried paleosurface. These identified features tend to contain a low frequency of other cultural materials while displaying no internal structural components. Burned rock pavements are defined as an extremely dense arrangement of tightly arranged burned rock forming a relatively flat, articulated surface (Trierweiler 1996). Only four features identified as burned rock pavements were observed during the investigations with three found as internal features within larger burned rock middens (Trierweiler 1996). 
Once defined, the study looked at artifact and burned rock content, geographic setting, and ages of the varying tested features types. This included 55 middens, 18 mounds, 32 concentrations, and four pavements. Aside from form and composition, a considerable difference in artifact content was recognized between the burned rock mounds and burned rock middens. The amount of lithic debitage in middens was almost seven times more than found in mounds with an average of 1,212 lithics per $\mathrm{m}^{3}$ in middens and 180 lithics per $\mathrm{m}^{3}$ in mounds. The artifact count in the burned rock concentrations and burned rock pavements was also considerably lower than in middens with an average of 221 and 203 lithics per $\mathrm{m}^{3}$, respectively (Trierweiler 1996).

In contrast, the amount of burned rock per $\mathrm{m}^{3}$ was considerably higher in burned rock mounds than in burned rock midden concentrations. The average count of burned rock per $\mathrm{m}^{3}$ in mounds was 4,375 as opposed to 1,000 in middens, 1,080 in pavements, and 539 in concentrations. To counter the argument that a higher rate of fracturing in mounds resulted in a higher individual rock count, the investigations took the average rock weight of each individual specimen to determine the average rock weight of each feature type, therefore being able to determine if smaller rocks (due to fracture) occurred more in mounds. The results showed a similar mean rock weight in middens $(0.14 \mathrm{~kg})$ versus mounds $(0.14$ $\mathrm{kg}$ ). Of interesting note, the average rock weight in burned rock concentrations $(0.24 \mathrm{~kg})$ and in burned rock pavements $(0.29 \mathrm{~kg})$ were considerably larger. The author's interpretation for this phenomenon is based on the assumption of the use of rocks in cooking facilities.

If we assume that the rocks were used as heat sinks to prolong elevated temperatures in the respective features, and discarded when they fragmented to such an extent that this function was no longer efficient, the similarity in rock size between mounds and middens implies that the discard threshold, and therefore the requirements for thermal properties of the rocks, was similar in mounds and middens (Trierweiler 1996:594).
Therefore, the reasoning for the larger rocks in burned rock concentrations and pavements is accounted to abandonment rather than from deliberate discard of rocks (Trierweiler 1996).

The geographic setting of the features again showed a marked difference between the features labeled burned rock mounds and burned rock middens. Burned rock mounds were observed almost exclusively in upland settings with the few found in depositional settings being located on upland slopes and benches, subject to low order colluvial and slopewash sedimentation (Trierweiler 1996). The middens, however, were observed primarily located in depositional lowland settings with a few found on upland settings on colluvial benches. The middens found in depositional settings were found on "Holocene alluvial fan deposits, Holocene colluvial toeslope deposits, or spanning the alluvial/colluvial boundary at the margin of valleys" (Trierweiler 1996). In contrast, the burned rock concentrations were observed in almost equal distribution between depositional lowlands and stable upland settings or Pleistocene terrace. The burned rock pavements were all associated with Holocene terraces although the low amount of examples did not allow for a conclusion on a relationship to geographic settings.

In determining the age of the burned rock features at Fort Hood, 72 radiocarbon ages were obtained from 49 of the features. The dates ranged from 110-5,240 B.P. with the majority of the radiocarbon assays coming from the midden deposits. The midden deposit assays revealed intermittent use during the last approximately 5,500 years with the majority of the radiocarbon ages falling between 900 and 2,500 B.P. Interestingly, a marked gap in the range of dates was noticed between 2,500 and 3,200 B.P. The dates suggest a period of intensive midden use during "the latter Archaic and the earlier Late Prehistoric periods, which generally agrees with the recovered projectile point assemblage" (Trierweiler 1996:612).

The dates acquired from 29 radiocarbon samples from the burned rock mounds date between 200 to 4,500 B.P. with 18 younger than 2,000 B.P. and 11 older than 2,800 B.P. This suggests a Late Archaic to Late Prehistoric occupation. The few radiocarbon dates from the burned rock concentrations $(n=4)$ and 
the burned rock pavement $(\mathrm{n}=1)$ yielded dates between 1,300 B.P. and 4,600 B.P. However, the author notes that the few dates obtained from these feature types is "extremely unlikely [to be]....representative of the ages of burned rock clusters [concentrations/ pavements] as a whole, which almost certainly span a considerably longer period" (Trierweiler 1996).

Overall, the investigations and subsequent reporting of the investigations at Fort Hood adequately highlight the numerous problematic issues surrounding investigations on burned rock concentrations ranging from function to chronological utilization. The investigation does attempt to outline a "simplistic" distinction between burned rock mounds and middens and the numerous types within each category (Trierweiler 1996). In addition, the authors suggest expanded research with larger data sets concentrating on artifact and burned rock content, geographic setting, and ages of the varying tested features types.

\section{Four BURNED Rock MIDDEN SITES ON the Greater EDWards PlateaU}

The investigation of four burned rock midden sites in west central Texas was undertaken by TARL based on the results of excavations by TxDOT archaeologists between 1978 and 1988. These excavations were conducted on the Honey Creek site (41MS32) in Mason County, the Corn Creek sites (41MK8 and 41MK9) in McCulloch County, and the Heard Schoolhouse site (41UV86) in Uvalde County. A total of six middens were investigated with one midden at each site except for three middens at site 41MK9. These sites all span the central Edwards Plateau and represent the varying physiographic regions focused in SWCA's current tri-county study area. These regions consist of the Mesquite Plains (Corn Creek sites), the Llano Uplift (The Honey Creek site), and portions of the Edwards Plateau (Heard Schoolhouse site). The four sites were chosen by TARL based on their similarities of feature types and general excavation methods. Each of the site's excavations concentrated on the burned rock features by using relatively small metric units, arbitrary levels, and 1/4inch screening with the same basic research question: "What patterns of past human behavior do burned rock middens represent?" (Black et al. 1997).
This investigation is widely accepted as containing the prevailing notion of burned rock modeling and utilization (Hunziker 2007). The resulting work Hot Rock Cooking on the Greater Edwards Plateau (Black et al. 1997) defined burned rocks as "center-focused" cooking facilities combining Weir's (1976) Type 1 and 2 features. In determining regional midden attributes, the investigations also included an analysis of burned rock midden sites in an 18county study area crossing the Edwards Plateau from north-to-south (Black et al. 1997:31-41). In addition to San Saba and Mills counties, the study area included Brown, Coleman, Concho, McCullough, Llano, Gillespie, Bandera, Kinney, Uvalde, Medina, Kimble, Edwards, Real, Kerr, Menard, and Mason counties. Below is a summary of the excavation of each of the four sites, followed by a summary of their research.

\section{The Honey Creek site}

The Honey Creek site was initially recorded in October 1987 on a northern high terrace-bench overlooking Honey Creek in central Mason County, approximately 5.5 miles southwest of Mason, Texas. The site extends from the edge of the terrace upslope at least $50 \mathrm{~m}$. The site is approximately 0.6 acres $(50$ x $50 \mathrm{~m}$ in size), with cultural material, including a 15 x $20 \mathrm{~m}$ burned rock midden, visible on the surface. It was investigated with limited test excavations on November 3-12, 1987, by SDHPT, only a month after it was first recorded. No determinations as to the site's eligibility for listing on the NRHP or for designation as an SAL were made, but a research design for further mitigation investigations was included in the report. Data recovery excavations were carried out from November 23, 1987 through April 1988 (Black et al. 1997:104).

During testing, the midden was described as being relatively small with a slight depression, that could be a possible oven area, and dark ashy soil, with an arrow point (no indication of typology), debitage, and manos found nearby. As no charcoal samples were submitted for radiocarbon assay during site testing, only the presence of diagnostic tools indicated the temporal associations for the observed cultural material. The authors primarily used the cultural 
chronology developed by Weir (1976) and Prewitt (1981). The site's diagnostic material (including a Bell-Andice, Early Triangular, Travis-like, untyped arrow point, Edwards, and Scallorn- or Edwardslike), pointed to two separate occupation periods: the San Geronimo and Clear Fork phases of the (Early and Middle) Archaic period, and the Austin Phase of the Late Prehistoric period (SDHPT 1987:24-27).

Based on the recovery of the Early Archaic to Late Prehistoric diagnostics and the discovery of a burned rock midden, TxDOT (formerly SDHPT) decided to conduct data recovery investigations at the Honey Creek Site. Excavations began in late November 1987, and continued into mid April 1988. A total of 30 features were recorded during the excavations consisting mostly of discrete clusters of burned rocks divided into two categories designated "primary" and "dispersed" features with the features appearing to "stand apart" from the general rocks spread across much of the site (Black et al. 1997:112). In addition, the excavations recovered a total of 104 projectile points, 285 bifaces, 28 unifaces, 176 cores, 32 pieces of groundstone, 64 modified flakes, and 36,311 pieces of debitage.

The investigations were able to determine general periods of occupation at the site based on the amount of diagnostic artifacts recovered from the site. Using Johnson and Goode's (1994) chronology, seven time periods were identified correlating with the artifacts recovered. These consist of: the Early Archaic, the Middle Archaic, the Late Archaic I, the Late Archaic II (Transitional), the Early Post-Archaic (Austin), the Late Post-Archaic to early Historic (Toyah), and the Historic (ranching) periods.

The excavations concentrated on investigating the features with special emphasis on the burned rock midden observed during testing. Materials, including samples, recovered from the investigations enabled the identification of four units independent of stratigraphy and the time periods outlined by the sites artifact chronology. These were identified as Analytical Units (AUs) 1-4 with AU 1 comprising materials dating from the late Early Archaic (ca. 3600 B.C.) or earlier, AU 2 comprising materials spanning the Middle and Late Archaic periods (3600 B.C.-A.D. 800), AU 3 comprised of post-Archaic (Transitional
Archaic to Late Prehistoric) and early historic cultural materials (A.D. 800-1750?), and AU 4 being the midden (A.D. 1100-A.D. 1700) (Black et al. 1997). The site was found to be occupied most heavily during the post-Archaic to early Historic (within AU 3 and AU 4).

In many areas the stratification of the Honey Creek site was gradual. This resulted in rather narrow bands of stratigraphic zones from "old" near the bedrock and "young" towards the surface, which did not clearly correspond with the materials associated with the identified time periods above. Radiocarbon dating also proved to complicate matters further, rather than clearing things up. Thus, the researchers in the end identified, where possible, features to the Late Prehistoric and Archaic periods.

\section{The Corn Creek Sites}

The Corn Creek sites (41MK8 and 41MK9) were initially recorded by SDHPT in 1973, with testing conducted in 1978-1979, followed immediately by more extensive excavations (Black et al. 1997). TARL archaeologists worked with the sparse information available from the fieldwork and within the confines of dated methodologies to compile a report on the investigations nearly 20 years after the excavations (Black et al. 1997). The sites lie just south of the Colorado River in the northeastern corner of McCullough County. Both of the sites occupy rocky benches overlooking Corn Creek, a small intermittent tributary of the Colorado River, with site 41MK8 located east of the creek and 41MK9 located west of the creek. The sites are approximately 0.5 -mile from each other with the investigated portions located within the current FM 765 ROW. The sites lie within the southern reaches of the Mesquite Plains physiographic subregion with the local geology consisting of Pennsylvanian limestones, shales, and sandstones (Black et al. 1997). Although both sites share similar soils on raised settings overlooking Corn Creek, site 41MK8 shows signs of accumulated colluvial materials and more erosion than site $41 \mathrm{MK} 9$ which sits at a slightly higher elevation.

Three burned rock features identified as middens were observed on site $41 \mathrm{MK} 8$ with the archaeo- 
logical investigations concentrating on one of the middens. The TARL investigation on the middens was limited due to overall shallow site deposits, poor organic preservation, and sampling limitations during the data recovery. The midden appeared to be an accumulation of burned rock as a result of repeated use as a cooking facility. Dating the feature proved difficult based on a wide temporal range of recovered diagnostic tools and radiocarbon dates. A total of 11 projectile points were recovered from the entire data recovery investigations, with five recovered from within the feature itself. These five points consisted of two Nolan points, one Pedernales point, and two unidentified points likely from the Late Archaic (Black et al. 1997). Counter to the chronology implied by the recovered projectile points, the radiocarbon dates only show Late Prehistoric midden use (Black et al. 1997). The conclusion of the report was that the midden represented an accumulation of "... repeated construction of cooking facilities, some or many of which involved baking in slablined and possibly earth-sheltered ovens" (Black et al. 1997:201).

Site $41 \mathrm{MK} 9$ was determined to be more of an intensive occupation locale than $41 \mathrm{MK} 8$ with three burned rock features labeled middens and considerably more artifacts. Two of the features were reported to have formed as the result of repeated construction of cooking facilities while the third feature appeared to be a shallow lens of burned rock that was described as either an "....eroded feature....or they [the burned rock] could represent some different behavior pattern such as dumping (Black et al. 1997:202,205)." Although 30 projectile points were recovered during the investigations, the shallow soils on the site did not allow for a discrete cultural deposit. Therefore, the investigation determined that the majority of the cultural material can be attributed to Late Prehistoric activity with the Middle and Late Archaic diagnostic artifacts "....represent[ing] residual remains that were present in the vicinity prior to Late Prehistoric times (Black et al. 1997)."

Based on the investigated burned rock features, the recovered artifacts, and the radiocarbon dating results at the Corn Creek sites, the sites were determined to have been occupied at sporadic times between the Early to Late Archaic with an increased occupation during the Late Prehistoric. The conclusions explaining each site's occupation and midden attributes were limited by the sparse information available from the fieldwork and dated methodologies employed nearly 20 years prior.

\section{The Heard Schoolhouse Sites}

The Heard Schoolhouse site (41UV86) is a small open campsite situated along Mine Creek, a tributary of the Dry Frio River, in northern Uvalde County, Texas. The site sits on an ancient terrace of the Dry Frio with little evidence of alluvial deposits. The site was initially recorded in 1981 by TxDOT prior to the construction of FM 1051 and later intensively investigated with testing and subsequent data recovery excavation from 1982-1983. The initial survey recorded two burned rock middens, one disturbed by bulldozing and the other lying outside of the ROW (Black et al. 1997). The disturbed burned rock midden was the focus of later investigations.

The site was estimated to cover a roughly $200-x-$ $100-\mathrm{m}$ area with a concentrated $25-\mathrm{x}-25-\mathrm{m}$ area containing a dense deposit of artifacts and the midden. Upon its initial discovery, the site was recorded as having a wide assortment of cultural materials on the surface with the small burned rock feature within the ROW. The feature appeared recently disturbed with a bulldozer cut through the center of the midden removing approximately $10-20 \mathrm{~cm}$ of cultural deposits (Black et al. 1997). In addition, a small pothole was located in the northern portion of the midden. However, the two disturbances did not end up being greatly damaging to the overall deposits (Black et al. 1997).

The burned rock midden had a low dome shape and measured $14.7 \times 15.3 \mathrm{~m}$ and varied in thickness from $20-55 \mathrm{~cm}$, with a calculated volume of $49 \mathrm{~m}^{3}$. It consisted of a homogeneous deposit of a dark gray loam and abundant burned rocks with a well-defined central area (Black et al. 1997). The burned rock feature was interpreted as the accumulation of burned rock from numerous cooking facilities or ovens and assumed to be centrally focused. 
Although none of these ovens (which presumably were rock lined) was found intact, in the central portion of the midden, there were a few larger slabs and smaller rocks suggestive of dismantled hot rock beds (Black et al. 1997:233)

Unfortunately, the excavation methods utilized in the field did not collect adequate amounts of fill to assess the remains and utilization of the feature.

A combination of diagnostic materials and radiocarbon dates recovered from within the feature were dated to the Austin phase, ca. 500-950 B.P. (Black et al. 1997). In addition, the cultural materials and radiocarbon dates from areas adjacent to the feature reveal an increased occupation at the Heard Schoolhouse site during the Austin Phase. The results of the investigation also indicate a later period of Austin Phase occupation of the site extending to A.D. 1450 (500 B.P.), in contrast to the conventional date of A.D. 1300 (650 B.P.) (Black et al. 1997).

\section{Four Burned Rock Midden Sites INTERPRETATION}

The six burned rocks middens investigated at the Honey Creek site, the Corn Creek sites, and the Heard Schoolhouse site were dated using 33 radiocarbon assays combined with diagnostic artifacts, site stratigraphy, and mussel shell racemization (Black et al. 1997). Utilizing these methods, one of the middens was determined to be an entirely Archaic feature, two appear to have begun in the Archaic and continued in the Late Prehistoric, and three are considered entirely Late Prehistoric (Black et al. 1997). With these results, the report generalizes that "...many middens in west central Texas date wholly or partially to the Late Prehistoric period" (Black et al. 1997).

Black et al.'s (1997:91-93) analysis also included an examination of the distribution of burned rock midden sites (recorded as of July 1993) and their locations compared to areas where sotol and oaks are known to grow. These particular species were chosen because sotol and oak acorns are believed to be the principal foodstuffs cooked in burned rock middens. They also included in their analysis the distribution of bedrock type, indicating that burned rocks middens are almost always comprised of burned limestone or sandstone and not granite or other igneous rocks (Black et al. 1997:93).

They determined that sotol coverage alone did not correspond with the location of burned rock middens, but the middens were almost entirely within the coverage of oak savanna. The small portion of the 18-county study area that has granitic outcrops contains almost no burned rock middens, evidence that leans heavily towards granitic rocks as unsuitable for hot rock cooking and thus not used by prehistoric peoples. Finally, they overlaid the extent of sotol coverage, oak savanna, and site percentages by county, and observed that the counties with the highest percentages of burned rock midden sites are located in areas where sotol and oak savanna are found together (Black et al. 1997:98).

In addition to the regional study, the report summarizes and outlines deficiencies in investigations on central Texas burned rock middens by previous investigations. A caveat to this conclusion was outlined on the difficulty in determining structure from a cooking facility that exhibits "intrusive, disruptive, regenerative, and additive" characteristics (Black et al. 1997:270). The report sums up a good description of middens by stating:

Middens are complex, accumulative, episodic, multicausal phenomena that, characteristically, formed over long spans of time on stable land surfaces (Black et al. 1997:271).

With this in mind, the report outlines how midden research should account for variability in individual middens with consideration not only to available resources, landscape context, settlement context, seasonality, climatic conditions, and other cultural attributes, but also account for relative preservation, age, scale, and post-depositional transformations (Black et al. 1997). 


\section{CAMP BowIE}

Camp Bowie is a 9,297-acre training area for the Texas Army National Guard in Brown County, Texas. The area is mapped within the Mesquite Plains of the Rolling Plains physiographic region in central Texas, just west of Lampasas Cut Plain, and north of the Llano Uplift (NHPRP 1978). The area is characterized as gently sloping to hilly topography within the Colorado River basin. Lewis Creek, the Devils River, and MacKinnaly Creek are the main intermittent streams within the camp boundaries feeding into Pecan Bayou, the primary river drainage in Brown County located east/northeast of Camp Bowie. The area is predominantly uplands with isolated areas of depositional soils near the main drainages and the eastern portions of the camp closest to Pecan Bayou.

An investigation of 18 prehistoric sites at Camp Bowie was conducted by the Center for Archaeological Research (CAR) at the University of Texas at San Antonio (Mauldin et al. 2003). The fieldwork for the investigations was conducted between the fall of 1999 and the summer of 2001 . The sites were initially recorded during various inventory surveys between 1993 and 1998 (Wormer and Sullo-Prewitt 2001). Sixteen of the sites contained at least one burned rock midden, and three of those sites contained multiple middens. Because of the preponderance of features identified to be burned rock middens, the report centers on the discussion of burned rock midden attributes and research issues (Mauldin et al. 2003). These issues focus on when the middens were used, the function of the middens, the items processed in the middens, and the patterning of inter- and intra-site midden locations (Mauldin et al. 2003).

The investigations looked at previous research in their determination of burned rock feature designation and definition. Citing previous work on defining burned rock midden typology, the report follows a general typology of four major types of middens devised in Weir's (1976) dissertation The Central Texas Archaic. Type 1 middens are "oval and mounded in shape with no surface indication of any subsurface features" (Weir 1976:34). Weir distinguished these middens as having high artifact densities and frequently exceeding $25 \mathrm{~m}$ in length. Type 2 middens are described as a "circular aggregation of burned rock around a central pit" (Weir 1976:35). Weir states that these features are usually represented by a slight depression towards a central pit with a lower density of artifacts as compared to domed middens. Type 3 middens are similar to Type 2 middens only smaller and originating from the ground surface (Creel 1986). Type 4 middens, according to Weir, are burned rock scatters which can be described as thin layers of burned rocks or "sheet middens" as described in the Camp Bowie report (Mauldin et al. 2003:140).

Although the report generally follows these distinctions when describing the middens throughout the individual site testing summaries, the report does not distinguish between midden types when it analyzes midden chronology, function, subsistence, and locality. However, the analysis appears to focus on the domed and annular types of burned rock accumulations. Aside from this distinction, the report provided an in-depth interpretation of midden use not only in the Camp Bowie, but in the northern portions of central Texas.

The chronology of the middens investigated at Camp Bowie revealed dates primarily between 500 B.P. and 1,250 B.P. This dating combined with additional regional investigations mainly consisting of the work in Black and Creel's (1997) investigation of four burned rock midden sites on the Edwards Plateau, points to a Late Prehistoric focus for the midden use. This report dismisses the idea of younger dates attributed to middens as occurring due to a "veneer" of Late Prehistoric deposits covering the Middle to Late Archaic deposits of middens. Although the report points out earlier middens are likely, the features in the general area of Camp Bowie are "primarily Late Prehistoric in age, at least from the radiocarbon dates" (Mauldin et al. 2003).

Analyzing the function of the Camp Bowie middens involved a variety of different data sets and pointed to the central thermal feature model for burned rock middens. This model suggests that middens are a result of a centralized cooking features or "earth ovens" (Black et al. 1997). This deduction of a centralized thermal feature model was taken from analyzing the patterns of burned rock count, size, and weight 
relative to the central area of the midden (Mauldin et al. 2003). An interesting observation was made at one the middens at Camp Bowie. By analyzing the radiocarbon dates, rock size differences, and fluctuating patterns in soil susceptibility from the best dated midden, the archaeologists realized that the evidence indicated that the vast majority of the midden debris being formed in a relatively short amount of time, with several periods of intensive use (Mauldin et al. 2003).

Archaeologists also looked at what food resources were being processed in the Camp Bowie middens. Although mussel shells and faunal remains were recovered from the middens, carbonized geophytes were determined to be most likely processed in the middens (Mauldin et al. 2003). This was determined from comparing midden deposits with non-midden deposits. Wild onion, dog's tooth violet, and Eastern camas were identified from the 400 recovered carbonized geophyte bulbs and bulb fragments with camas being most abundant (Mauldin et al. 2003). The study suggests that although examples of other possible food resources were found in association with the middens (agave, acorns, animals, etc.); the middens were designed for the processing of highstarch plants, such as camas (Mauldin et al. 2003).

The analysis on the inter- and intra-site locations of middens was attempted by the Camp Bowie investigations with no definitive conclusions. Initial analysis looked at determining if the sites were "residential" or "special purpose" sites (Mauldin et al. 2003). However, due to numerous variables that the study was unable to definitively account for, the conclusions were based on several assumptions. This included the question about what exactly "...the material culture generated by such a system [residential function], even over a few years, [would] look like?" (Mauldin et al. 2003:209). Regardless, the investigations determined the midden sites displayed characteristics of a "special purpose" site with a "... narrow range of artifacts and feature types..." and showing a "...distribution of material [that] should be centered on the midden" (Mauldin et al. 2003). Looking at midden locations throughout central Texas, the study suggested that fuel wood resources are the critical component in understanding midden reuse. With this idea, the study outlined the idea of the excessive cost associated with the amount of resource depletion from wood collection over time may account for midden reuse and times of abandonment. In addition, this correlation may account for the "...strong association of burned rock middens with oak" (Mauldin et al. 2003). 


\title{
Chapter 8
}

\section{Site Synthesis and Comparative Analysis}

\author{
Mindy L. Bonine and Michael R. Chavez
}

\section{Site 41SS164 in a Regional Historic ConteXt}

To reiterate the purpose of this comparative analysis, three studies were utilized to place site 41SS164 in a regional historic context. The first was to gather and tabulate basic data of all of the previously recorded archaeological sites (as of June 2007) located in the San Saba, Mills, and Lampasas Counties research area. With this data, a comparative analysis was conducted to determine if site $41 \mathrm{SS} 164$ is a typical site type in the research area (typology) or was occupied during the same period as other sites in the research area (chronol$o g y$ ). The second study was to obtain information on archaeological sites in the research area that have been tested, or more thoroughly investigated, and conduct a more in depth comparative analysis of typology and chronology between these sites and 41SS164. Finally, a closer look at investigations of burned rock features from the three natural subregions of Texas was undertaken based on the presence of burned rock features at site $41 \mathrm{SS} 164$ and the limited information regarding these features from previous investigations within the tri-county research area. The results of these analyses are described below under each category.

\section{Patterns in Previously Recorded Sites}

A total of 330 sites were found in the San Saba, Mills, and Lampasas counties research area. Of these, six trinomials contained no associated information and were not plotted on the Atlas or TARL maps, and eleven others had no associated information other then their location. In addition, 52 of the 330 previously recorded sites were historic-era sites with no prehistoric components. These 52 sites, along with the six sites with no information at all, are not included in the analysis; thus, leaving 272 sites. The eleven sites with only location information were able to be utilized in some of the analyses, but their contribution was limited. The comparative analysis below concentrates on two major themes, chronology and typology.

The chronological analysis of the previously recorded sites in the San Saba, Mills, and Lampasas Counties research area utilizes as its data set all of the sites that contained temporal information within the research area, without consideration for the natural subregions of Texas in which the sites are located. This is primarily due to the small data set available for the analysis (see below), which would be further reduced if separated by natural subregion. Although an analysis of any differences in periods of occupation in different natural subregions would be very useful, the research area would have to be significantly expanded to obtain enough data to make any meaningful observations. As we are limited to the tri-county research area in this analysis, it was decided to conduct the chronological research with just one combined data set.

The analysis of typology, however, did contain a sufficiently large data set to categorize the information by natural subregion (Llano Uplift, Lampasas Cut Plain, and Mesquite Plains). As this research is intended to observe the interplay between three converging natural subregions, this division was the first step in the analysis. Of the 272 previously recorded sites in the San Saba, Mills, and Lampasas Counties research area, 87 are located within the Lampasas Cut Plains, 125 in the Llano Uplift, and 60 in the Mesquite Plains. The division by natural subregion is not geographically equal, as the Lampasas Cut Plain is the largest in area, followed by the Llano Uplift and the Mesquite Plains. However, within the second largest subregion, the Llano Uplift, are more previously recorded sites $(n=125)$ than in either of the other subregions. The largest subregion in the research area, Lampasas Cut Plains, has the second highest number of previously recorded sites. This absence of a discrete relationship between the size of the natural subregion and the number of previously recorded sites indicated that at least 


\section{8-2 Chapter 8}

for the tri-county research area, size does not matter as much. Whether this is a factor of realistic numbers of prehistoric sites in each area or just a factor of the level of recordation in each natural subregion is unknown, and may never be known. Nevertheless, for the purposes of this analysis, this discrepancy has been taken into account.

\section{Chronology}

This segment of the comparative analysis is designed to see if 41SS164 was occupied at a roughly similar timeframe as the rest of the research area, and if the sandstone burned rock midden was created at the same time as other middens in the vicinity. While organizing the data for analysis, the researchers quickly realized that only a small portion of the data set was compatible within this research topic. About 109 previously recorded sites (41.8 percent) contained temporal information in their records, and among those, only 56 had recorded both the specific diagnostic projectile points used to determine the probable periods of occupation and the list of the periods of occupation. None had specific dates recorded on file from radiocarbon assays or other means of absolute dating. The remaining 53 sites listed a period of occupation but not the data (i.e., only general descriptions of "dart" points or other information) used to make that determination. The original research strategy was to incorporate all 109 sites in the analysis of chronology, but the degree of inconsistency and risk of major statistical errors by not using a common baseline chronological sequence made it clear that only the 56 sites, which had both specific diagnostic information and a stated period of occupation, could be used in the analysis.

Similarly, as several different chronological sequences have been developed for the Central Texas archaeological region, and it is not known which one was used to correlate diagnostic points to time periods, all of the 56 sites were recalibrated to Collins (2004) to provide a common baseline for analysis. Collins was chosen as the baseline partially because it is one of the most recent attempts at a chronological sequence in the Central Texas archaeological region, and it included most of the diagnostic projectile points, called "archeological style intervals" in Collins (2004) recovered from the 56 sites. Table 8.1 shows the original periods of occupation listed by the original researchers for the sites used in this analysis, the recalibrated dates based on Collins (2004:fig.3.9a), and the diagnostic tools found at each site.

Prehistoric occupation in central Texas has been recorded from the Paleoindian period through the Late Prehistoric period. Within these timeframes, there is relatively homogenous set of diagnostic tools within the Central Texas archaeological region, which has enabled archaeologists to make connections between artifacts and occupation periods. There are approximately 35 "archaeological style intervals" listed by Collins (2004:fig. 3.9a) for the Central Texas archaeological region, and 21 of those types have been recorded in the 56 sites in the research area that list diagnostic tools, including Angostura, Bulverde, Castroville, Clovis, Darl, Ensor, Fairland, Folsom, Frio, Golondrina, Marcos, Martindale, Marshall, Montell, Nolan, Pedernales, Perdiz, Plainview, Scallorn, Travis, and Uvalde. A few points were found at these 56 sites that were not in Collins' list, but are known to exist in central Texas according to Turner and Hester (2002). They include Fresno, Wells, Ellis, Cliffton, Gower, and Kent. Only two archaeological sites with point information in the research area contained diagnostic points that are generally associated with other areas of the state, including an Abasolo point from south Texas (41MI7) and a Gary point from east Texas (41LM28). Finally, three point types were recorded in the site forms that were not described in either Collins (2004) or Turner and Hester (2002), namely the Guilford, Zephyr, and Granbury types.

Fifty-six sites are a rather small data set to use in making generalizations about the intensity of settlement in the three counties on either side of the Colorado River at different time periods, but one trend was noticed that, if proven to be significant, may contribute to the understanding of cultural change in the Central Texas archaeological region. Of those sites that have projectile point information and can be attributed to a particular occupation period, there are slightly more sites dating to the Late Archaic or Late Archaic/Late Prehistoric than any site with Paleoindian to Middle Archaic period components, 
Table 8.1. Previously Recorded Sites with Temporal Information

\begin{tabular}{|c|c|c|c|c|c|c|}
\hline Site & Site Type & $\begin{array}{l}\text { Archaeological } \\
\text { Periods }\end{array}$ & Diagnostic Tools & $\begin{array}{c}\text { Period Based on } \\
\text { Collins (2004:fig 3.9a) }\end{array}$ & $\begin{array}{l}\text { Common in } \\
\text { Central Texas? }\end{array}$ & Physiography \\
\hline $41 \mathrm{MI} 93$ & Open Campsite & Paleoindian & Clovis & Early Paleoindian & yes & Mesquite Plains \\
\hline 41SS116 & Open Campsite & \begin{tabular}{|c} 
Late Archaic/Late \\
Paleoindian
\end{tabular} & $\begin{array}{c}\text { Plainview(4) and } \\
\text { Archaic Dart } \\
\text { points }(7)\end{array}$ & Early Paleoindian & yes & Llano Uplift \\
\hline 41SS135 & Multicomponent & $\mid \begin{array}{c}\text { Late Paleoindian/ } \\
\text { Historic }\end{array}$ & $\begin{array}{l}\text { Plainview and } \\
\text { Historic Pottery }\end{array}$ & Early Paleoindian & yes & Llano Uplift \\
\hline 41SS127 & Open Campsite & $\begin{array}{l}\text { Paleoindian- } \\
\text { Historic }\end{array}$ & $\begin{array}{c}\text { Golondrina and } \\
\text { Crockery }\end{array}$ & Late Paleoindian & yes & Llano Uplift \\
\hline 41LM3 & $\begin{array}{c}\text { Open Campsite } \\
\text { with Midden/Burials }\end{array}$ & \begin{tabular}{|} 
Paleoindian-Late \\
Prehistoric
\end{tabular} & $\begin{array}{c}\text { Almost All Types of } \\
\text { points }\end{array}$ & $\begin{array}{l}\text { Paleoindian to Late } \\
\text { Prehistoric }\end{array}$ & yes & $\begin{array}{c}\text { Lampasas Cut } \\
\text { Plains }\end{array}$ \\
\hline $41 S S 14$ & Lithic Scatter & $\begin{array}{c}\text { Paleoindian/Late } \\
\text { Prehistoric }\end{array}$ & Fresno and Folsom & $\begin{array}{c}\text { Early Paleoindian and } \\
\text { Late Archaic* }\end{array}$ & yes & Llano Uplift \\
\hline $41 \mathrm{MI} 80$ & $\begin{array}{l}\text { Open Campsite } \\
\text { with Midden }\end{array}$ & Archaic & Martindale (2) & Early Archaic & yes & Mesquite Plains \\
\hline $41 \mathrm{MI} 14$ & Open Campsite & Early Archaic & Angostura (2) & Early Archaic & yes & Mesquite Plains \\
\hline 41SS96 & Open Campsite & $\begin{array}{c}\text { Late Paleoindian/ } \\
\text { Archaic }\end{array}$ & $\begin{array}{c}\text { Angostura and } \\
\text { Archaic Dart points }\end{array}$ & Early Archaic & yes & Llano Uplift \\
\hline 41SS121 & $\begin{array}{l}\text { Open Campsite } \\
\text { with Midden }\end{array}$ & Early Archaic & Wells & Early Archaic* & yes & Llano Uplift \\
\hline $41 \mathrm{MI} 47$ & Multicomponent & Archaic/Historic & $\begin{array}{l}\text { Glass, Frio, } \\
\text { Martindale, and } \\
\text { Marshall }\end{array}$ & Early and Late Archaic & yes & $\begin{array}{l}\text { Lampasas Cut } \\
\text { Plains }\end{array}$ \\
\hline 41LM28 & $\begin{array}{l}\text { Open Campsite } \\
\text { with Midden }\end{array}$ & $\begin{array}{l}\text { Late Paleoindian/ } \\
\text { Late Prehistoric }\end{array}$ & \begin{tabular}{|c|} 
Angostura(2), Ellis, \\
Fairland, Gary, \\
Guilford, Marshall, \\
Montell, Zephyr, \\
Cliffton, Granbury, \\
and Scallorn \\
\end{tabular} & $\begin{array}{c}\text { Early and Late Archaic/ } \\
\text { Late Prehistoric* }\end{array}$ & $\begin{array}{c}\text { Gary in East Texas; } \\
\text { Guilford, Zephyr, } \\
\text { and Granbury not } \\
\text { known }\end{array}$ & $\begin{array}{l}\text { Lampasas Cut } \\
\text { Plains }\end{array}$ \\
\hline $41 S S 43$ & Open Campsite & $\begin{array}{l}\text { Early Archaic/ } \\
\text { Late Prehistoric }\end{array}$ & $\begin{array}{l}\text { Scallorn, Ensor, } \\
\text { Frio, Fresno, } \\
\text { Bulverde, Uvalde, } \\
\text { and Marcos }\end{array}$ & $\begin{array}{c}\text { Early and Late Archiac/ } \\
\text { Late Prehistoric }\end{array}$ & yes & Llano Uplift \\
\hline $41 \mathrm{Ml} 41$ & Open Campsite & Archaic & Nolan & Middle Archaic & yes & $\begin{array}{l}\text { Lampasas Cut } \\
\text { Plains }\end{array}$ \\
\hline 41SS18 & $\begin{array}{l}\text { Open Campsite } \\
\text { with Midden }\end{array}$ & Archaic & Nolan(3) & Middle Archaic & yes & Llano Uplift \\
\hline 41MI105 & Isolate & Middle Archaic & Nolan & Middle Archaic & yes & Mesquite Plains \\
\hline 41MI67 & $\begin{array}{l}\text { Open Campsite } \\
\text { with Midden }\end{array}$ & Middle Archaic & Travis & Middle Archaic & yes & Mesquite Plains \\
\hline $41 S S 40$ & Multicomponent & Archaic/Historic & $\begin{array}{c}\text { Gower and Historic } \\
\text { Whiteware }\end{array}$ & Middle Archaic* & yes & Llano Uplift \\
\hline $41 S S 120$ & $\begin{array}{l}\text { Open Campsite } \\
\text { with Midden }\end{array}$ & Late Archaic & Gower & Middle Archaic* & yes & Llano Uplift \\
\hline 41SS69 & $\begin{array}{l}\text { Open Campsite } \\
\text { with Midden }\end{array}$ & $\begin{array}{l}\text { Archaic/Late } \\
\text { Prehistoric }\end{array}$ & Travis and Scallorn & $\begin{array}{c}\text { Middle Archaic and Late } \\
\text { Prehistoric }\end{array}$ & yes & Llano Uplift \\
\hline $41 S S 137$ & Open Campsite & $\begin{array}{l}\text { Archaic/Late } \\
\text { Prehistoric }\end{array}$ & $\begin{array}{c}\text { Early Triangular, } \\
\text { Travis, and Arrow } \\
\text { point }\end{array}$ & $\begin{array}{c}\text { Middle Archaic and Late } \\
\text { Prehistoric* }\end{array}$ & yes & $\begin{array}{l}\text { Lampasas Cut } \\
\text { Plains }\end{array}$ \\
\hline 41MI94 & $\begin{array}{l}\text { Open Campsite } \\
\text { with Midden }\end{array}$ & $\begin{array}{l}\text { Middle Archaic/ } \\
\text { Early Prehistoric }\end{array}$ & $\begin{array}{l}\text { Pedernales(2), } \\
\text { Travis, and } \\
\text { Granbury }\end{array}$ & Middle and Late Archaic & $\begin{array}{c}\text { Granbury not } \\
\text { known }\end{array}$ & Mesquite Plains \\
\hline 41LM54 & Multicomponent & Archaic & $\begin{array}{l}\text { Dart points and } \\
\text { Ensor point }\end{array}$ & Late Archaic & yes & $\begin{array}{l}\text { Lampasas Cut } \\
\text { Plains }\end{array}$ \\
\hline
\end{tabular}




\section{8-4 Chapter 8}

Table 8.1. Previously Recorded Sites with Temporal Information, continued

\begin{tabular}{|c|c|c|c|c|c|c|}
\hline Site & Site Type & $\begin{array}{c}\text { Archaeological } \\
\text { Periods }\end{array}$ & Diagnostic Tools & $\begin{array}{c}\text { Period Based on } \\
\text { Collins (2004:fig 3.9a) }\end{array}$ & $\begin{array}{c}\text { Common in } \\
\text { Central Texas? }\end{array}$ & Physiography \\
\hline 41MI92 & $\begin{array}{l}\text { Open Campsite } \\
\text { with Midden }\end{array}$ & Archaic (?) & Pedernales & Late Archaic & yes & Mesquite Plains \\
\hline 41MI100 & Open Campsite & Late Archaic & Pedernales(2) & Late Archaic & yes & $\begin{array}{c}\text { Lampasas Cut } \\
\text { Plains }\end{array}$ \\
\hline 41LM53 & Open Campsite & Late Archaic & Ensor-like point & Late Archaic & yes & $\begin{array}{l}\text { Lampasas Cut } \\
\text { Plains }\end{array}$ \\
\hline 41SS42 & Open Campsite & Late Archaic & $\begin{array}{l}\text { Castroville, Dart } \\
\text { points, and Nails }\end{array}$ & Late Archaic & yes & Llano Uplift \\
\hline 41SS164** & Open Campsite & Late Archaic & Fairland & Late Archaic & yes & Llano Uplift \\
\hline 41SS35 & Rockshelter & Late Archaic & Castroville & Late Archaic & yes & Llano Uplift \\
\hline 41SS99 & $\begin{array}{l}\text { Rockshelter with } \\
\text { Midden }\end{array}$ & Late Archaic & Castroville & Late Archaic & yes & Llano Uplift \\
\hline 41MI18 & Open Campsite & Late Archaic & Castroville & Late Archaic & yes & Mesquite Plains \\
\hline $41 \mathrm{MI} 23$ & Open Campsite & Late Archaic & $\begin{array}{l}\text { Castroville and } \\
\text { Ensor (possible) }\end{array}$ & Late Archaic & yes & Mesquite Plains \\
\hline $41 \mathrm{MI} 24$ & Open Campsite & Late Archaic & Marcos & Late Archaic & yes & Mesquite Plains \\
\hline 41MI96 & Open Campsite & Late Archaic & Marcos & Late Archaic & yes & Mesquite Plains \\
\hline $41 \mathrm{MI} 73$ & Open Campsite & Late Archaic & Montell & Late Archaic & yes & Mesquite Plains \\
\hline $41 \mathrm{MI} 60$ & $\begin{array}{l}\text { Open Campsite } \\
\text { with Midden }\end{array}$ & Late Archaic & Ensor & Late Archaic & yes & Mesquite Plains \\
\hline $41 \mathrm{MI} 8$ & $\begin{array}{l}\text { Open Campsite } \\
\text { with Midden }\end{array}$ & Late Archaic & Castroville & Late Archaic & yes & Mesquite Plains \\
\hline $41 \mathrm{MI} 22$ & Open Campsite & Late Archaic (?) & $\begin{array}{l}\text { Castroville } \\
\text { (possible) }\end{array}$ & Late Archaic & yes & Mesquite Plains \\
\hline $41 S S 140$ & Multicomponent & $\begin{array}{c}\text { Late Archaic/ } \\
\text { Historic }\end{array}$ & Ensor and Historics & Late Archaic & yes & Llano Uplift \\
\hline 41MI68 & Open Campsite & Middle Archaic & Castroville & Late Archaic & yes & Mesquite Plains \\
\hline 41MI88 & Open Campsite & $\begin{array}{c}\text { Middle Archaic } \\
(?)\end{array}$ & Bulverde and Ensor & Late Archaic & yes & Mesquite Plains \\
\hline $41 \mathrm{MI} 28$ & Open Campsite & $\begin{array}{l}\text { Middle Archaic/ } \\
\text { Late Archaic }\end{array}$ & $\begin{array}{l}\text { Dart Points and } \\
\text { Pedernales } \\
\text { Preform }\end{array}$ & Late Archaic & yes & Mesquite Plains \\
\hline 41MI82 & Open Campsite & $\begin{array}{c}\text { Middle/ } \\
\text { Transitional } \\
\text { Archaic }\end{array}$ & Kent & Late Archaic* & yes & Mesquite Plains \\
\hline $41 \mathrm{MI} 83$ & $\begin{array}{l}\text { Open Campsite } \\
\text { with Midden }\end{array}$ & Middle Archaic & $\begin{array}{c}\text { Pedernales and } \\
\text { Kent }\end{array}$ & Late Archaic* & yes & Mesquite Plains \\
\hline $41 S S 150$ & Lithic Scatter & $\begin{array}{c}\text { Late Archaic/Late } \\
\text { Prehistoric }\end{array}$ & $\begin{array}{l}\text { Castroville and } \\
\text { Arrow points }\end{array}$ & $\begin{array}{c}\text { Late Archaic and Late } \\
\text { Prehistoric }\end{array}$ & yes & Llano Uplift \\
\hline $41 S S 32$ & Rockshelter & \begin{tabular}{|c} 
Late Archaic/Late \\
Prehistoric
\end{tabular} & Perdiz and Ensor & $\begin{array}{c}\text { Late Archaic and Late } \\
\text { Prehistoric }\end{array}$ & yes & Llano Uplift \\
\hline $41 \mathrm{MI} 27$ & $\begin{array}{l}\text { Open Campsite } \\
\text { with Midden }\end{array}$ & $\begin{array}{c}\text { Late Archaic/Late } \\
\text { Prehistoric }\end{array}$ & $\begin{array}{c}\text { Darl, Fairland, and } \\
\text { Arrow point }\end{array}$ & $\begin{array}{c}\text { Late Archaic and Late } \\
\text { Prehistoric }\end{array}$ & yes & Mesquite Plains \\
\hline $41 \mathrm{MI} 87$ & Open Campsite & \begin{tabular}{|c|} 
Late/Transitional \\
Archaic
\end{tabular} & \begin{tabular}{|c|} 
Pedernales, Ensor, \\
and Scallorn
\end{tabular} & $\begin{array}{c}\text { Late Archaic and Late } \\
\text { Prehistoric }\end{array}$ & yes & Mesquite Plains \\
\hline $41 \mathrm{MI} 75$ & Open Campsite & Late Prehistoric & Scallorn & Late Prehistoric & yes & Mesquite Plains \\
\hline $41 \mathrm{MI} 77$ & $\begin{array}{l}\text { Open Campsite } \\
\text { with Midden }\end{array}$ & Late Prehistoric & Scallorn & Late Prehistoric & yes & Mesquite Plains \\
\hline $41 \mathrm{MI} 30$ & Open Campsite & $\begin{array}{c}\text { Late/Transitional } \\
\text { Archaic }\end{array}$ & $\begin{array}{l}\text { Montell and Plano- } \\
\text { convex Thin Biface }\end{array}$ & Late Prehistoric & yes & $\begin{array}{l}\text { Lampasas Cut } \\
\text { Plains }\end{array}$ \\
\hline
\end{tabular}


Table 8.1. Previously Recorded Sites with Temporal Information, continued

\begin{tabular}{|c|c|c|c|c|c|c|}
\hline Site & Site Type & $\begin{array}{c}\text { Archaeological } \\
\text { Periods }\end{array}$ & Diagnostic Tools & $\begin{array}{c}\text { Period Based on } \\
\text { Collins (2004:fig 3.9a) }\end{array}$ & $\begin{array}{c}\text { Common in } \\
\text { Central Texas? }\end{array}$ & Physiography \\
\hline 41 SS25 & Open Campsite & Not Reported & Scallorn & Late Prehistoric & yes & Llano Uplift \\
\hline 41 SS125 & Open Campsite & $\begin{array}{c}\text { Paleoindian/Late } \\
\text { Prehistoric }\end{array}$ & $\begin{array}{c}\text { Scallorn and Dart } \\
\text { points }\end{array}$ & Late Prehistoric & yes & Llano Uplift \\
\hline 41 LM9 & $\begin{array}{c}\text { Open Campsite } \\
\text { with Midden/Burials }\end{array}$ & Toyah & Perdiz & Late Prehistoric & yes & Lampasas Cut \\
Plains
\end{tabular}

*Note: Several of these projectile points are not referenced in the "archeological style periods" in Collins (2004:fig 3.9a) and their associated archaeological periods were derived by Turner and Hester (1999) and recalibrared to Collins (2004).

** Survey data only

with a ratio of 1.3:1. At first glance this would mean that the research area was settled far more heavily in the Late Archaic and Late Prehistoric than in earlier periods, but with such a small data set this conclusion may be erroneous. The preponderance of later period sites in the research area may be more of a factor of geomorphological and post depositional processes (younger sites are better preserved) than actual numbers of sites, so this pattern should be considered very tentatively while additional data is compiled.

Another intriguing pattern was found that may complicate future analyses. The number of sites that show evidence of occupation in only one period is much higher than those that span two or more prehistoric occupation periods (multi-period), about 3:1. These single-occupation period sites are largely based on the presence of one or two identifiable projectile points, and are generally not ideal representatives of temporal patterns derived from multiple lines of evidence. Alternatively, a multi-period site with good stratigraphic separation can provide information concerning period-specific data and cultural change between multiple occupation periods (Col- lins 2004; Ferring 1986; Johnson 1987). Ideally, the information gathered from the multi-period sites can be correlated to dated sites that have been occupied within a narrower time frame, i.e., a single-occupation period site. The single-occupation period site can in turn provide additional depth of understanding to a particular occupation period that the multi-period site could not. ${ }^{1}$ If there are a high percentage of multi-period sites in an area, there is a much better chance that a certain number of them would have sufficient stratigraphic separation to make realistic connections with single-occupation period sites. However, with such a low ratio of multi-period sites to single-occupation period sites, this chance is much less likely.

Comparing the data from the 56 sites in Table 8.1 to the points recovered from 41SS164, which are a Fairland point from the surface and a Pandale point from the intact cultural zone (97.7-97.6 m), the first observation is that a Pandale point has not been located anywhere else in the San Saba, Mills, and Lampasas Counties research area. Indeed, no other points from the Lower Pecos region have been recovered from any site in the research area, although

\footnotetext{
${ }^{1}$ For example, a rockshelter may be able to provide good stratigraphic data and temporal associations with diagnostic materials, but does not explain much about large habitation activity areas. An open campsite dating to one of the periods at the rockshelter with less stratigraphic overprinting and better spacial resolution would be able to make those types of connections.
} 
one point from east Texas (Gary) and one from south Texas (Abasolo) have been recovered. Gary points have a long associated temporal range, from the Middle Archaic to the Late Prehistoric, but the Abasolo point dates to the Early to Middle Archaic, and Pandale point is associated with the Early Archaic (ca. 4,000-2,500 B.c. in Turner and Hester [2002], would be Middle Archaic if calibrated to Collins [2004]). Although various inferences about group mobility through central Texas could be made with this information, there is currently not enough data to make significant connections. Only their presence is noted at this point.

The Fairland point is linked with the Transitional Archaic in Turner and Hester (2002) (ca. 300 B.C.-A.D. 700) or the Late Archaic in Collins (2004) (ca. 1,400-1,800 B.P.). At least two other sites in the tri-county research area have Fairland points in their inventories, including 41LM28 in Lampasas County and 41MI27 in Mills County. Although rare in this research area, Fairland points have been known to be rather common in the Central Texas archaeological region, and their presence at site 41SS164 is not unusual. Likewise, the timeframe associated with this point is also well represented in the research area.

\section{TyPOLOGY}

As mentioned above, the data set for the following analysis on typology is divided by natural subregion-Llano Uplift, Lampasas Cut Plains, or Mesquite Plains - to help determine if there are any observable differences in site patterns between these natural subregions within the tri-county research area. Within each subregion, the data set was analyzed based on two factors, site type and landform (discussed in Chapter 7). The analysis will be presented in two forms: an examination of sites on certain landforms within each natural subregion and a discussion of site types within the natural subregions.

Site 41SS164 is only moderately represented as an open campsite located on a terrace overlooking a watercourse within the Llano Uplift natural subregion. Of the 125 previously recorded prehistoric sites in the natural subregion with location information, 44 of them, or about 35.2 percent, are prehistoric sites also located on terraces. Of these, 12 (27.3 percent) are open campsites with observed burned rock middens, 17 (38.6 percent) are open campsites with hearth features or scatters of burned rock, 5 (11.4 percent) are lithic scatters, seven (15.9 percent) are multicomponent sites, and three ( 6.8 percent) are sites with no data other than their location (Table 8.2).

Alternatively, about 81 sites (64.8 percent) are located in other geographic areas in the Llano Uplift, including floodplains ( $\mathrm{n}=16 ; 19.7$ percent), hillslopes ( $\mathrm{n}=55 ; 67.9$ percent), hilltops ( $\mathrm{n}=8 ; 9.9$ percent), and upland drainages $(\mathrm{n}=2 ; 2.5$ percent) (see Table 8.2). As can be seen, hillslopes have the highest number of previously recorded sites in the Llano Uplift within the tri-county research area (primarily San Saba County), and also contains the highest diversity of sites, including not only open campsites and lithic scatters, but also rockshelters, multi-component sites, burials, bison jump sites, and pictographs.

For the Lampasas Cut Plains, hillslopes also have the highest number of previously recorded sites $(33 ; 37.9$ percent), followed by terraces $(25 ; 28.7$ percent), floodplains $(10 ; 11.5$ percent), hilltops and hilltop/ slopes $(12 ; 13.8$ percent), and upland drainages ( 7 ; 8.1 percent). Both hillslopes and terraces have the widest variety of sites, including open campsites, open campsites with burned rock middens, lithic procurement and/or lithic scatters, rockshelters, and multi-component sites. Several interesting sites were recorded in this area, including two open campsites with middens and burials (classified under open campsite with midden; 41LM3 and 41LM9), a rockshelter with a flexed burial and pictographs (41LM2), a rockshelter with burned rock middens (41MI4), and a rockshelter with a midden and burials (41LM16). All of these sites were classified under rockshelters. In addition, several bedrock mortars were found at site 41LM36, which also contained evidence of an open campsite (and classified as such).

In the Mesquite Plains, where the least number of previously recorded sites are present in the tri-county research area, terraces have the highest number of previously recorded archaeological sites $(23 ; 38.3$ percent), with hillslopes a close second (17; 28.3 percent); hilltops and hilltop/slopes comprise 18.4 
Table 8.2. Matrix of Previously Recorded Sites in San Saba, Mills, and Lampasas Counties

\begin{tabular}{|c|c|c|c|c|c|c|c|c|c|c|c|c|c|c|}
\hline & 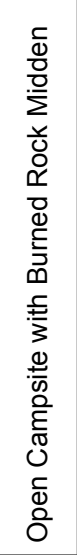 & 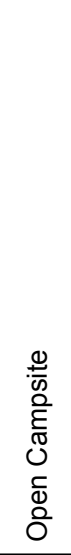 & 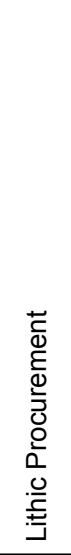 & 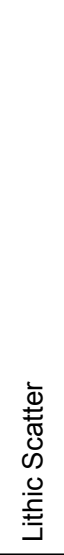 & 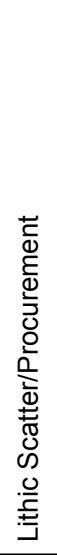 & 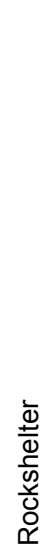 & 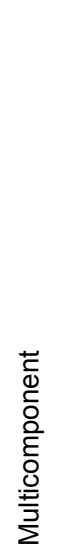 & 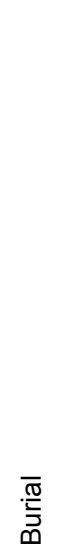 & 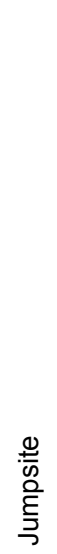 & $\begin{array}{l}\frac{c}{2} \\
\frac{0}{0} \\
\frac{0}{0} \\
\frac{0}{0} \\
\frac{0}{2}\end{array}$ & $\begin{array}{l}\frac{1}{\pi} \\
\stackrel{5}{0} \\
\sum\end{array}$ & $\begin{array}{l}\stackrel{\Phi}{\pi} \\
\frac{\pi}{0} \\
\underline{0}\end{array}$ & 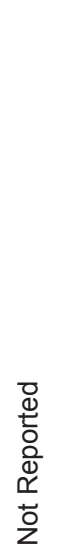 & 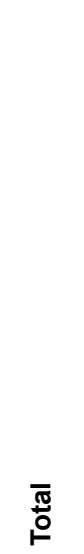 \\
\hline Lampasas Cut Plains & 10 & 29 & 14 & 10 & 8 & 4 & 4 & & & & & 4 & 4 & 87 \\
\hline Llano Uplift & 30 & 36 & 8 & 15 & 5 & 13 & 9 & 1 & 1 & 1 & & 1 & 5 & 125 \\
\hline Mesquite Plains & 20 & 24 & 6 & 2 & 2 & & 2 & & & & 1 & 1 & 2 & 60 \\
\hline Total & 60 & 89 & 28 & 27 & 15 & 17 & 15 & 1 & 1 & 1 & 1 & 6 & 11 & 272 \\
\hline Percent & 22.1 & 32.7 & 10.3 & 9.9 & 5.5 & 6.3 & 5.5 & 0.4 & 0.4 & 0.4 & 0.4 & 2.2 & 4.0 & 100.0 \\
\hline \multicolumn{15}{|l|}{ Lampasas Cut Plains } \\
\hline Floodplain & 1 & 5 & & & 1 & & & & & & & 1 & 2 & 10 \\
\hline Terrace & 5 & 8 & 1 & 2 & 3 & 1 & 3 & & & & & 2 & & 25 \\
\hline Hillslope & 2 & 10 & 7 & 6 & 3 & 1 & 1 & & & & & 1 & 2 & 33 \\
\hline Hilltop & & 3 & 3 & 1 & & & & & & & & & & 7 \\
\hline Hilltop/Slope & 2 & & 2 & & 1 & & & & & & & & & 5 \\
\hline Upland Draiange & & 3 & 1 & 1 & & 2 & & & & & & & & 7 \\
\hline Total & & & & & & & & & & & & & & 87 \\
\hline \multicolumn{15}{|l|}{ Llano Uplift } \\
\hline Floodplain & 2 & 8 & 1 & 2 & & 2 & & & & & & 1 & & 16 \\
\hline Terrace & 12 & 17 & & 5 & & & 7 & & & & & & 3 & 44 \\
\hline Hillslope & 13 & 9 & 3 & 8 & 4 & 11 & 2 & 1 & 1 & 1 & & & 2 & 55 \\
\hline Hilltop & 1 & 2 & 4 & & 1 & & & & & & & & & 8 \\
\hline Hilltop/Slope & & & & & & & & & & & & & & 0 \\
\hline Upland Draiange & 2 & & & & & & & & & & & & & 2 \\
\hline Total & 30 & 36 & 8 & 15 & 5 & 13 & 9 & 1 & 1 & 1 & 0 & 1 & 5 & 125 \\
\hline \multicolumn{15}{|l|}{ Mesquite Plains } \\
\hline Floodplain & 2 & & & 1 & & & & & & & & & & 3 \\
\hline Terrace & 4 & 14 & 2 & & & & 2 & & & & 1 & & & 23 \\
\hline Hillslope & 7 & 5 & 1 & 1 & 2 & & & & & & & & 1 & 17 \\
\hline Hilltop & 4 & 3 & 2 & & & & & & & & & & & 9 \\
\hline Hilltop/Slope & 1 & & 1 & & & & & & & & & & & 2 \\
\hline Upland Draiange & 2 & 2 & & & & & & & & & & 1 & 1 & 6 \\
\hline Total & 20 & 24 & 6 & 2 & 2 & 0 & 2 & 0 & 0 & 0 & 1 & 1 & 2 & 60 \\
\hline
\end{tabular}


percent $(n=11)$, upland drainages 10.0 percent $(n=6)$, and floodplains 5.0 percent $(\mathrm{n}=3)$. Over 70 mortar holes were found on a terrace in the Mesquite Plains (41MI107), but otherwise the site types fall into the familiar range of open campsites, open campsites with burned rock middens, lithic scatters and/or lithic procurement sites, and a couple of multi-component sites.

Several patterns can be seen from the analysis of the data, although the meaning of such patterns is still tentative. First, the locations of open campsites with burned rock middens in the tri-county research area is highest in the Llano Uplift (where 41SS164 is located), followed by the Mesquite plains and the Lampasas Cut Plains. The ratio is about 3:2:1. Open campsites without defined burned rock middens (either scattered burned rock, hearths, or no burned rock) have a slightly different ratio, about 1.5:1:1 respectively. One would expect these open campsites to be located primarily on flat surfaces such as terraces, but this is not the case for any of the natural subregions in the tri-county research area. In the Llano Uplift portion of the research area, open campsites (either with or without burned rock middens) on terraces $(n=29)$ are roughly equal to those on hillslopes and hilltops $(n=25)$, but about three times as many than on floodplains $(\mathrm{n}=10)$, and almost 15 times more than upland drainages $(n=2)$. In the Mesquite Plains and Lampasas Cut Plains portions of the tri-county project area, there are slightly more sites on hillslopes and hilltops than on terraces, both about 1.1:1. In all three natural subregions there are at least a few open campsites on floodplains and upland drainages, but not enough to be statistically significant (see Table 8.2).

Evidently, the prehistoric occupants of the tri-county research area set up open campsites nearly equally as often on flat surfaces near water sources such as terraces, and on sloping or upland surfaces such as hillslopes and hilltops. The reason for this roughly equal choice between terraces and hillslopes/hilltops is not entirely clear, but it is present in the data set for all three natural subregions within the San Saba, Mills, and Lampasas Counties research area. If this pattern continues as more data is gathered for the tri-county research area, it may be an indicator for different land and resource utilization in the "crossroads" area between multiple natural subregions than in the "central core" of such areas.

Lithic scatters and lithic procurement sites, or a combination of both, all of which have similar compliments of artifacts and are formed through interrelated activities, occur in every topographic category within all three natural subregions (with the exception of hilltop/slope in the Llano Uplift) and are most prevalent on hillslopes (50 percent), followed by terraces (18.6 percent), hilltops and hilltop/slope (21.4 percent), floodplains (7 percent), and upland drainages (3 percent). Within each natural subregion, the Llano Uplift had the highest ratio of such sites on hillslopes to terraces and hilltop and hilltop/slopes, with 3:1:1, and the Mesquite Plains recorded the lowest ratio, with roughly $2: 1: 1$, respectively. The Lampasas Cut Plain contains a very similar ratio of roughly $2.6: 1: 1$, respectively (see Table 8.2). The statistical differences between the three natural subregions within the tri-county research area appear to be relatively minor, and all show the same pattern of hillslopes as the topographic choice for lithic procurement and production over any other type of landform. Other factors not addressed in this study, such as proximity to chert resources, exposed bedrock, or sources of water, may also be a major factor in choice of lithic scatter/procurement sites.

Seventeen rockshelters were found in the San Saba, Mills, and Lampasas Counties research area, thirteen of which were recorded in the Llano Uplift and the remainder $(n=4)$ in the Lampasas Cut Plains. As expected, the majority of the rockshelters (and the associated cultural material surrounding the rockshelter) were found in hillslopes, while a few were recorded in upland drainages, overlooking terraces, and just above floodplains (see Table 8.2). Rockshelters can be excellent resources for determining cultural change over time, as soil deposits slowly accumulate and seal in assemblages from roughly similar occupation periods. These shelters also are better at preserving organic material, including charcoal, than open campsites. The rockshelters in the tri-county research area often also contained additional features, including middens, pictographs, 
and burials (about 47 percent of rockshelters had one or more additional features).

As Table 8.2 shows, the other eight site types have far fewer sites per type than those discussed above. In addition, they are located in far fewer topographic categories. Only one bison jumpsite (41SS52) was recorded in the tri-county research area, and only one site with a burial as its only feature (41SS48) and one site with pictographs as its only feature (41SS77) have been recorded in the research area. All three of these sites were found in the Llano Uplift on a hillslope. However, two burials were found in rockshelters and two at campsites with burned rock middens in the Lampasas Cut Plains, and pictographs were found in one rockshelter in the Lampasas Cut Plains, three rockshelters in the Llano Uplift, and one open campsite with a midden in the Llano Uplift. As mentioned above, one site with mortar holes as the only feature (41MI107) was found on a terrace in the Mesquite Plains, but several other mortar holes were found in two open campsites with middens in the Lampasas Cut Plains, one lithic procurement site and one open campsite in the Llano Uplift, and two open campsites and three open campsites with middens in the Mesquite Plains. The presence of these types of archaeological sites adds significant diversity to the archaeological record, which would otherwise be solely informed by the preponderance of burned rock middens and lithic production sites. Unfortunately, there is such little data on these site types that there is not much that can be definitively said about them, other than recognizing their presence in the tri-county research area and to single them out as important contributors to the archaeological record.

Finally, fifteen sites with both prehistoric and historic components were recorded, with four in Lampasas Cut Plains, nine in the Llano Uplift, and two in the Mesquite Plains. These multi-component sites are somewhat rare in Texas archaeology, as the reasons regarding the choice of one location over another for a habitation or work site differed among mobile hunter-gatherer-forager groups and groups that focused on domestic livestock raising and farming.

Looking at just the raw numbers of sites in different landform settings, site $41 \mathrm{SS} 164$ is not part of the largest group of site types in the Llano Uplift (open campsites without burned rock middens have a slightly higher percentage), nor does it occupy the most prevalent landform (hillslopes have a slightly higher percentage of open campsites with burned rock middens). Nevertheless, site 41SS164 is still a common site type in the San Saba, Mills, and Lampasas Counties research area, and in the Llano Uplift in particular. In a broader context, terraces and hillslopes appear to be priority locations for prehistoric hunter-gatherer campsites in all three natural subregions (2:1 chance in the Lampasas Cut Plains; almost 4:1 chance in the Llano Uplift; and a 2:1 chance in the Mesquite Plains), and open campsites or open campsites with burned rock middens are the most likely sites to be found (about 54.8 percent of the time).

What does this information say about cultural practices and the exploitation of available resources among natural subregions very close to other natural subregions? In general, it is difficult to discern specific cultural changes from one period to the next with the given data, suggesting comparatively little change throughout these periods (in terms of subsistence and settlement patterns). The overall trend was to conduct large-scale cooking enterprises on the Llano Uplift side of the border, rather than in the Lampasas Cut Plains or the Mesquite Plains. The Lampasas Cut Plains is more likely the location of campsites without large burned rock middens and areas where lithic procurement and production took place. By comparison, the Mesquite Plains have far fewer locations were good lithic material was procured. The Llano Uplift has by far the best rockshelters. However, other than these general observations, the statistical differences between different landforms and site types in different natural subregions are quite narrow, indicating that several different landforms were used for several different activities, and at times multiple features representing very different activities occupied the same space. Perhaps instead of relegating certain activities to separate areas, the trend at this "crossroads" area was to conduct multiple activities at the same place, perhaps at the same time. What this means for resource exploitation across natural subregions is not exactly 
clear, but it is a beginning for further research into the topic. ${ }^{2}$

Eventually, the successful analysis of such data sets in a wider, more detailed study may be used in the interpretation of foraging strategies or other processually oriented research topics trying to connect the archaeological record to cultural change. For example, the optimal foraging theory established by Winterhalder and Smith (1981) and Butzer's (1982) view of culture within a human ecosystem (i.e., a cultural landscape), and the foraging strategy models developed by Bettinger and Baumhoff (1982; traveler and processor model), Binford (1980; collector and forager model), and Woodburn (1982; delayed return versus immediate return economic model) could be informed by the data set. Unfortunately, the inconsistent character of previously recorded sites presents a somewhat vague or ambiguous data set with no clear division between one site type or another or one time period or another, but this may also result from the rather limited available data. Alternatively, these data do hint or suggest patterns of prehistoric occupation in this area, which can only be considered through additional research.

\section{Patterns in Tested ArChaeological SITES}

As mentioned in Chapter 7, the data set for sites that have been investigated beyond the basic recording stage within the San Saba, Mills, and Lampasas Counties research area has been difficult to compile. No literature pertaining to testing or data recovery investigations was located during a search of the records at the THC. The only reports that were found in the search pertained to investigations of sites on private property; these four monographs were published in the Bulletin of the Texas Archeological Society and as a Master's thesis from Texas Tech University. All of these reports consist of a detailed description of the site in question, with a heavy focus on the artifacts recovered and a small amount of analysis on site utilization. Nevertheless, some interesting patterns may emerge from a study of these four sites in comparison with 41SS164, which may be further refined through critique and the addition of new information. For the purposes of this analysis, two basic themes, chronology and typology, will be the focus of the discussion.

As with the discussion of the chronology of the previously recorded site analysis above, the data set of tested archaeological sites available for study was not large enough to separate out into natural subregions (i.e., Mesquite Plains, Llano Uplift, and Lampasas Cut Plains) and still make any meaningful observations. Although there is at least one site located within each natural subregion, there are numerous other factors that have influenced the data set, and the analysis of one site is not enough to make any generalizations about the nature of sites within a particular subregion or the relationship between subregions at their "crossroads." Thus, the following analysis will not incorporate a discussion of natural subregions.

\section{Chronology}

Of the four tested archaeological sites within the San Saba, Mills, and Lampasas Counties research area selected for study, only one contains evidence of a Late Paleoindian occupation (41LM3; McCann site), four have Late Prehistoric occupations, and all but

Table 8.3. Chronology of Selected Tested Sites

\begin{tabular}{|c|c|c|}
\hline & Site & Chronology \\
\hline 1 & 41 SS19 & $\begin{array}{r}\text { Middle or Late Archaic through to } \\
\text { Neo-American }\end{array}$ \\
\hline 2 & 41 SS20 & Late Prehistoric Toyah \\
\hline 3 & 41 SS51 & Early Archaic to Late Prehistoric \\
\hline 4 & 41 LM3 & Paleoindian to Prehistoric \\
\hline 5 & 41 SS164 & Middle to Transitional Archaic \\
\hline
\end{tabular}

\footnotetext{
${ }^{2}$ There are several other variables that may influence this trend, including water sources, geology, chert resources, flora and fauna resources, seasonality, etc. As this research only concentrated on landform, general site type and chronology, many of these variables are not incorporated into the research. Thus, further investigations will likely need to include such topics to gain a more realistic picture.
} 
one contain evidence of at least one Archaic period occupation (41SS20; the Finis Frost site appears to be exclusively Late Prehistoric). The chronology of each tested site is presented in Table 8.3 below, using the terms that the original researchers used.

As the sites were investigated at different times (three were excavated in the late 1960s and early 1970s using chronological sequences developed in the 1950s and 1960s, and the fourth was excavated in the 1990s using chronology refined around the same time), it seemed prudent to recalibrate all of the chronological sequences based on one system to provide a standardized baseline from which to compare the occupation dates of each of the sites. Thus, it was decided to recalibrate the chronology to Collins (2004: fig. 3.9a). Even the preliminary analysis of artifacts from site 41SS164 used a different chronology than Collins (in fact, the chronology presented in Turner and Hester [2002] was utilized to define the period of occupation). Thus, Table 8.4 provides the original chronological sequences of the sites used by the original researchers and also presents the recalibrated periods based on Collins (2004). This recalibration is not intended to discount the chronologies used by the previous researchers (including Turner and Hester [2002]), but to simply provide a common set of terms and timeframes for comparison. The sites, with the exception of 41SS164, did not have any radiocarbon dates to provide an absolute date for any site component, thus diagnostic projectile points were used to derive the original chronology as well as the recalibrated chronology. ${ }^{3}$

As seen in Table 8.4, the tested sites selected for comparative analysis are quite variable in their known chronologies, emphasizing the extremely long time in which the Central Texas archaeological region has been occupied by prehistoric peoples. There are no clear periods of occupation that can be discerned by the temporal ranges exhibited by the tested sites (for example, whether or not certain areas were occupied at certain times), as even within this small data set there are some sites that were occupied in a small temporal range and others that were inhabited at various times over several thousands of years. The sites with the longest occupation periods, the Sloan site and the McCann site, were two of the sites with a definable stratigraphy (with 41SS164 being the only other site with an observed stratigraphy), and the researchers did attempt to connect each stratigraphic layer with a period of occupation using projectile point typology. However, the efforts were only moderately successful, as there was evident artifact mixing at the Sloan site, and possible post depositional artifact movement at the McCann site. In both cases, the largest features, both burned rock middens, could not be definitively dated to a specific time period (or were the result of compression of several occupation episodes and can only be identified as Archaic), and thus could not be used to account for changes in activities over time at the site. Site 41SS164 also retained an observable stratigraphy, but as the cultural component was extremely compressed, there was no way to stratigraphically separate different occupation surfaces to describe changes over time. The sites with shorter periods of occupation (at least as determined by the recovered evidence), may explain some cultural practices within a chronological period (e.g., the Late Prehistoric), but neither contains sufficient stratigraphic separation to identify specific occupation surfaces and their associated activities.

In terms of the similarities or differences in the recovery of diagnostic projectile points among the four tested sites and site 41SS164, one is immediately struck by the wide differences in the number of projectile point varieties found at the sites. The tested sites either have six or less types (including 41SS164) or they have eleven or more (see Table 8.4). Generally, the more projectile point types found, the longer the timeframe of occupation. This is certainly the case with this data set. Not surprisingly, the bulk of the projectile points recovered from the tested sites are referenced in Collins (2004:fig. 3.9a), and the exceptions (Fresno, Yarbrough, Gower, Early Triangular, Young, Alba, and Wells) are all known to occur in central Texas. The Harrell site, for which the point was named, is technically in North Texas, but is actually only about 125 miles due north of 41SS164. The others, including Washita points from the Texas panhandle, Tortugas and Abasolo points from south Texas, and Pandale points from the lower Pecos, are exceptions to the general rule, but not

\footnotetext{
${ }^{3}$ See Chapter 6 for more information on the results of the radiocarbon assays.
} 


\begin{tabular}{|c|c|c|c|c|c|}
\hline $\begin{array}{l}\vec{A} \\
\text { S } \\
\vec{D} \\
\stackrel{A}{A}\end{array}$ & 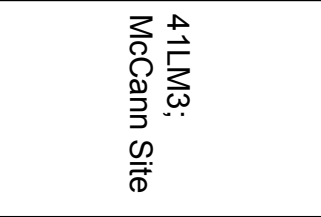 & 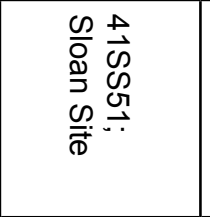 & 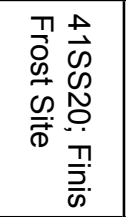 & 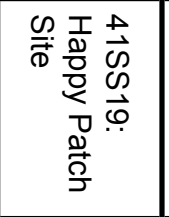 & $\stackrel{\infty}{\overparen{\infty}}$ \\
\hline 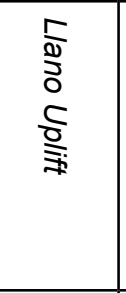 & 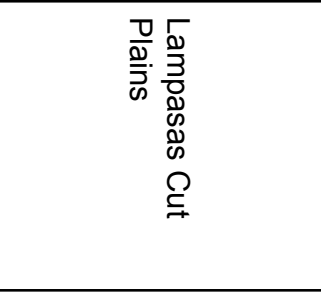 & 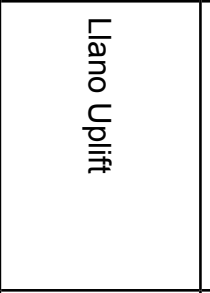 & 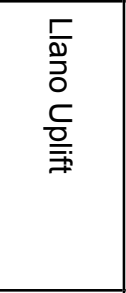 & 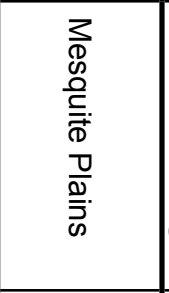 & 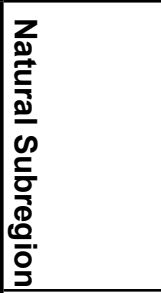 \\
\hline 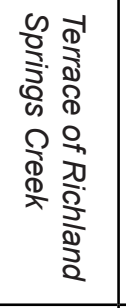 & 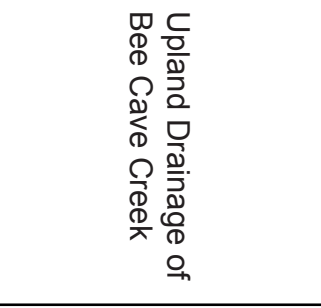 & 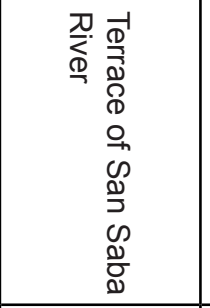 & 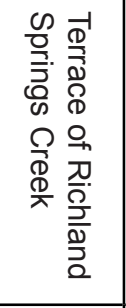 & 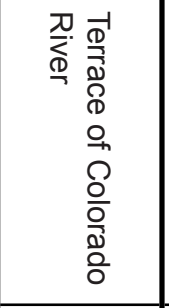 & $\begin{array}{l}\frac{1}{2} \\
\frac{2}{2} \\
\frac{0}{0} \\
\frac{1}{3}\end{array}$ \\
\hline$\frac{\overrightarrow{3}}{\stackrel{0}{2}}$ & 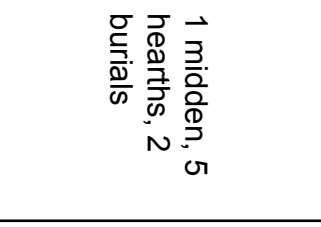 & $\begin{array}{l}\overrightarrow{3} \\
\overrightarrow{0} . \\
\frac{0}{1}\end{array}$ & $\begin{array}{l}z \\
\text { ż } \\
\text { จे }\end{array}$ & 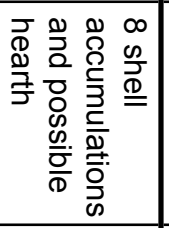 & 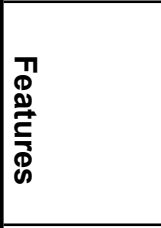 \\
\hline 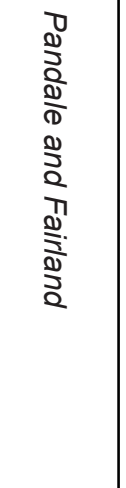 & 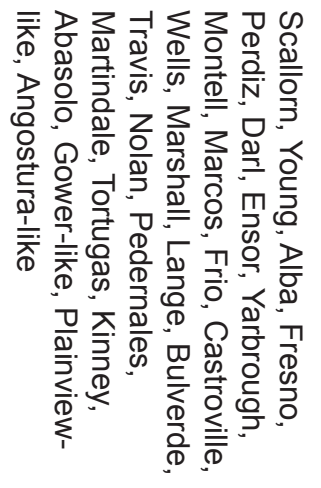 & 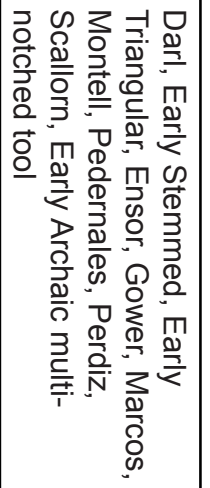 & 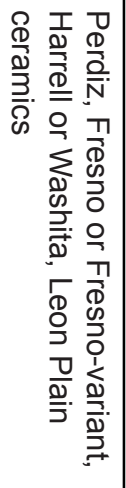 & 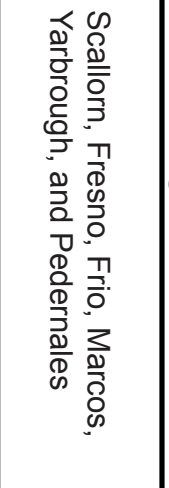 & 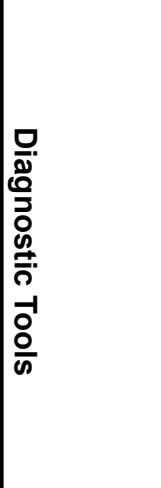 \\
\hline 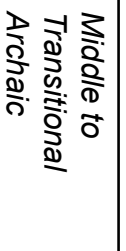 & 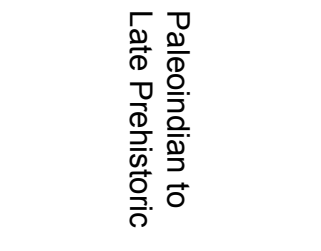 & 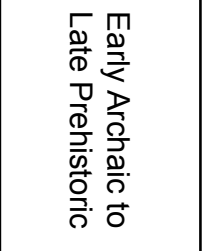 & 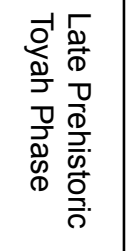 & 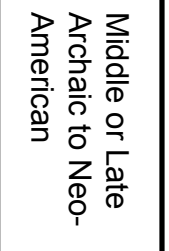 & 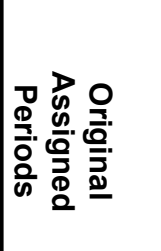 \\
\hline 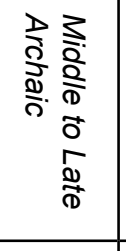 & 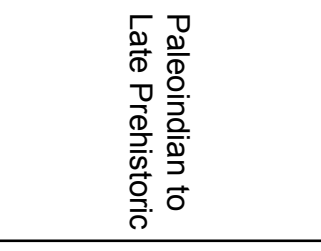 & 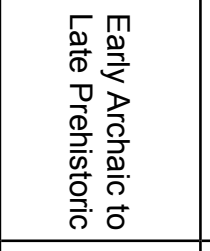 & 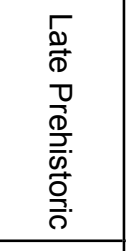 & 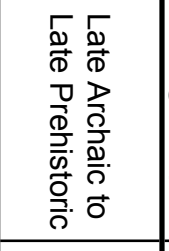 & 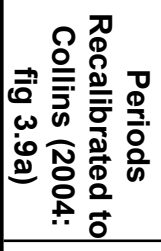 \\
\hline 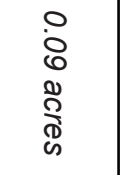 & $\begin{array}{l}\vec{\infty} \\
\dot{c} \\
\stackrel{0}{0} \\
\stackrel{\$}{\infty}\end{array}$ & 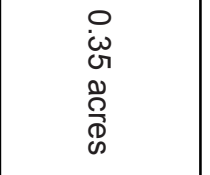 & 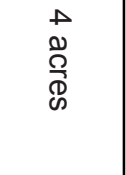 & $\begin{array}{l}\Delta \\
0 \\
\stackrel{0}{0} \\
\stackrel{\Phi}{\Phi}\end{array}$ & $\frac{\mathscr{N}}{\mathbb{N}}$ \\
\hline
\end{tabular}


enough information is known to make any general speculations as to the significance of their presence at the tested sites.

Just as archaeologists are much more comfortable with larger quantities of the same type of artifact, the fewer groups of artifacts that date to the same time frame are also highly desired because they indicate a more solid foundation for cultural pattern recognition. The Finis Frost site, with three diagnostic points and one ceramic type all dating to the Late Prehistoric, is a good example. Although 41SS164 is not one of those types of sites (two artifacts spanning thousands of years does not support a long-term site residence within each period), there appear to be sites that do have this information in the tri-county research area, and that information can be utilized to further refine artifact typology in the Central Texas archaeological region as well as connect these artifact types with features, occupation surfaces, and other evidence of site activity.

\section{TyPOLOGY}

Of the four tested archaeological sites within San Saba, Mills, and Lampasas Counties research area selected for study, three of them are located on terraces overlooking medium-to-large watercourses, and the fourth is located on an upland drainage relatively near an active watercourse. Site 41SS164 is also located in a terrace overlooking a medium watercourse. In general, terraces are landforms with high potential to contain intact sediments; thus, by association, it is likely that such sediments would also possess a high potential for intact buried archaeological deposits. However, the one site on an upland drainage, the McCann site (41LM3), does appear to be relatively unique in that multiple and likely longterm occupations at the site, which may have boasted a spring or other constant water source as one point, caused an artificial layering of stratigraphic zones of human trash (at least in the midden area). Thus, the site appeared to contain at least some semblance of stratigraphic zones. The landform on which the sites are located as well as the type of each tested site is presented in Table 8.5.

Table 8.5. Typology of Selected Test Sites

\begin{tabular}{|c|c|c|}
\hline & Site & Typology \\
\hline 1 & 41 SS19 & Open Campsite on Terrace \\
\hline 2 & 41 SS20 & Open Campsite on Terrace \\
\hline 3 & 41 SS51 & Open Campsite on Terrace \\
\hline 4 & $41 \mathrm{LM3}$ & $\begin{array}{c}\text { Open Campsite on Upland } \\
\text { Drainage }\end{array}$ \\
\hline 5 & 41 SS164 & Open Campsite on Terrace \\
\hline
\end{tabular}

All of the tested archaeological sites selected for comparative analysis are open campsites. Two sites, the Sloan site (41SS51) and the McCann site (41LM3) have some kind of burned rock feature or features. The Finis Frost site (41SS20) has no recorded features, and the Happy Patch site (41SS19) contains a possible burned rock hearth that was found to be mostly destroyed. Additionally, the Happy Patch site is the only site with shell accumulations, although the Sloan site did contain large quantities of shell within the excavation units. Site 41SS164 did not contain shell deposits within any of the excavation units or in the trench wall. Only the McCann site contained two burials. ${ }^{4}$

Of the sites with burned rock middens, the McCann site contained exclusively burned limestone rocks, site 41SS164 exhibited only burned sandstone, and the Sloan site saw a combination of the two. The burned rock middens at each of the three sites present an interesting juxtaposition, not only in terms of the types of rocks selected at each site, but also in terms of the structure of the burned rock middens themselves. At all three sites, the rocks selected for the cooking features were apparently obtained within the immediate vicinity. Even though the tri-county research area includes the transition point between limestone and sandstone bedrock, and a nomadic group could conceivably obtain their preferred cooking stones from not too far away, all three of the sites use the rock type that is right there: the McCann site

\footnotetext{
${ }^{4}$ Detailed information concerning the burials is noticeably lacking in the site files and nothing is mentioned at all in the Bulletin article. As these burials were located on private land and excavated well before the passage of the Native American Graves Protection and Repatriation Act in 1990, the landowner may have wished this information be kept confidential.
} 


\section{8-14 Chapter 8}

is located within the limestone area, site $41 \mathrm{SS} 164$ is located within the sandstone area, and the Sloan site is located exactly where these two bedrock types meet. In this case, both types of rocks could easily be found mixed on the surface.

As mentioned in the chronology section above, the Sloan site, the McCann site, and 41SS164 all have some form of observable stratigraphy, the very least of which is a disturbed zone, a midden zone, and a sub-midden zone. Both the McCann site's and site 41SS164's middens were contained in a single zone (with compressed stratigraphy occupying several chronological periods), but the Sloan site's midden spanned the two zones the researcher identified as the Late Archaic and the Late Prehistoric zones (Butler 2006). The middens dominated the sites, comprising the most visible accumulation of prehistoric cultural material, but the structure of each one was different. The McCann site's midden appeared to be a thick accumulation of material from innumerable cooking events on top of one another in a uniquely narrow space, the Sloan site's midden is a typical thick circular midden with a slight hump in the middle (the center was exposed on the ground surface while the edges were buried), and 41SS164's midden appeared to be a gradual slump across a large surface (ending in a roughly linear feature) and subsequently entirely buried by sediment. The reasons behind these variations in midden structure are not unique to these three sites, and are the source of numerous discussions among researchers. A more detailed discussion on burned rock middens is presented below.

\section{REGIONAL BURNED ROCK INVESTIGATION ANALYSIS}

The review of previous investigations on burned rock middens from Fort Hood (Treirweiler 1996), Camp Bowie (Mauldin et al. 2003), and four sites on the Greater Edwards Plateau (Black et al. 1997) was necessary to determine the possible function and utilization of the features at site 41SS164. This was accomplished by comparing burned rock feature attributes and characteristics from the previous investigations and determining if there was a difference between middens from the three physiographic regions accounted for in the San Saba, Mills, and
Lampasas counties study area. In addition, a proper definition needed to be established for the 41SS164 burned rock features based on the adamantly outlined definitions utilized in previous investigations. These definitions of the previously investigated burned rock middens were identified either from a modification of Weir's (1976) typology of four general midden types based on visible descriptors (mounds, annular, etc.) or Black's (1997) model of a revisited central focused cooking facility. The shared conclusion from these studies is that a considerable amount of additional research and data needs to be acquired from burned rock features and concentrations in central Texas.

The four basic midden types derived from Weir's The Central Texas Archaic (1976) consist of domed middens (Type 1), annular middens (Type 2), smaller annular middens (Type 3), and thin layers of burned rocks or "sheet middens" (Type 4). Weir's typology was widely accepted and well established in early interpretations of middens and the literature throughout the 1980's and into the early 1990's (Howard 1983; Creel 1986; Gearhart 1987; Prewitt 1994; Hester 1991). However, Black (1997) suggests in Hot Rock Cooking on the Greater Edwards Plateau, with its investigation of the four sites on the Greater Edwards Plateau, that Weir's Type 1 and 2 likely represent central focused cooking facilities (or Type 2 annular middens) that “....were not recognized as such because they were either badly eroded, recently disturbed, and/or inadequately investigated" (Black et al. 1997). Black (1997) also describes investigations on "sheet middens", or Weir's Type 4 middens, as largely being incipient domed middens, hearth scatters, and cooking residue from domestic structures (Garber 1987; Voellinger and Gearhart 1987; Weir 1976). Early studies believed these sheet middens could give a snapshot of an isolated period of time lending to the understanding of burned rock midden developmental processes (Voellinger and Gearhart 1987).

The features at site $41 \mathrm{SS} 164$ did not fit the earlier definitions of middens referred to in other burned rock studies. Feature 1 is a small discrete cluster of burned sandstone about $50 \mathrm{~cm}$ wide that was observed in the southern profile of BHT 1. The feature did not appear to be basin-shaped, but instead appeared to be an asymmetrical stack of rocks in 
profile. The sandstone rocks were observed to be generally around $8-15 \mathrm{~cm}$ in diameter and angular in shape. The stack was four-stones thick in some places, and, although several pieces of burned sandstone were located within $25 \mathrm{~cm}$ of the feature, it appeared to be a tight cluster all on its own. Since it was not further investigated, however, the exact shape of the feature is unknown.

Feature 2 was observed in both the north and south walls of BHT 1 as well as portions of BHT 2. Feature 2 is a long linear fire-cracked rock zone in a sheet-like pattern on a sloping surface. It was encountered in TUs 1, 2, and 3, extending across all three units from east to west. The feature was seen uninterrupted from north to south in each unit and was also visible in both wall profiles of BHT 1 on either side of all three units. The feature extended a total distance of $8.5 \mathrm{~m}$ east-west and under the roadway to the north of the excavation units for an unknown distance. The vertical extent of the feature within the hand-excavated units was from 97.9-97.6 $\mathrm{m}$ in elevation, and approximately $98.00-97.40 \mathrm{~m}$ across the BHT 1 profile. The $20 \mathrm{~cm}$ lens of burned sandstone did not appear internally stratified. If the feature was accumulated in more than one event, it was not discernable in the test excavations or BHT 1 profile. The rocks were tightly packed with little fine matrix amongst them. The fine matrix was similar to the surrounding soil deposits and had no staining, ash, or charcoal flecking. No central pit feature or other distinct pattern was noted in the feature. The feature mostly resembles the "burned rock pavements" outlined by Treirweiler (1996), the burned rock scatters labeled by Weir (1976), and the widely accepted "sheet midden" description (Decker et al. 2000; Black et al. 1997).

Geomorphologically, the intact alluvial deposits that contained Features 1 and 2 lay beneath road-related deposits and a disturbed interface deposit containing shared attributes of each. The intact natural deposits were determined to likely be part of a late Pleistocene alluvial fill composed of four distinct horizons with the feature isolated to the buried A horizon. The deposits have a considerable slope towards the creek with the cultural material becoming progressively buried towards the creek. The radiocarbon dates and the recovery of the Early/Middle Archaic
Pandale point suggest that the intact deposits represent stratigraphic compression with roughly $30 \mathrm{~cm}$ of sedimentation occurring in the last four millennia. This compaction and the slope towards the creek suggest possible post depositional transformation of the original feature structure.

With regards to the utilization of sandstone as opposed to limestone as thermal heating elements in burned rock features, none of the previous investigations addressed the issue or made a distinction between features based on rock type. Black et al. (1997) briefly touches on the fact that middens are either sandstone or limestone likely due to there thermal properties as opposed to granitic rock types. Therefore, based on geologic data, the middens rock types appear to correlate with the prevailing geologic parent material of the respective area in which features are located.

The only conclusive determination of the features at site 41SS164 was that they are the remnants of cooking features that utilized sandstone as heating elements. The separation of approximately 2,700 years between the radiocarbon dates recovered from Feature $2(200 \pm 40$ B.P. and $2900 \pm 40$ B.P) and an even older date of the diagnostic Pandale point (4700-4100 B.P.), reinforces the conclusion of the geomorphologic investigations of stratigraphic compression. Additionally, the constraints of the narrow ROW prevented acquiring the full dimensions of Feature 2, which was the more promising of the two features. Therefore, the features at site 41SS164 were determined to provide inadequate data and materials to reach a conclusion concerning either feature structure or utilization

However, site data did lend itself to a larger scale, regional understanding of the distribution and frequency of burned rock features and critical resource utilization. This was seen in the analysis of the flotation samples and radiocarbon samples. The four radiocarbon samples were found to be live oak and mesquite wood charcoal and the two flotation samples yielded additional wood charcoal, including the white oak group. This correlates with Black's research on the location of middens in relation to oak savanna/woodland and to areas of predominantly limestone/sandstone outcrops (Black et al. 1997; 
Figure 26 and 27). In addition, the macrobotanical analysis did not recover any evidence of sotol at site 41SS16. This observation supports Black's research in that site 41SS164 is in an area that does not coincide with the modern occurrence of sotol (Black et al. 1997; Figure 25).

Overall, utilizing Black et al. (1997) criteria, the site did not meet the three dimensions for determining the potential of midden sites to produce productive research directions. These three dimensions are the degree of organic preservation, degree of structural integrity, and degree of site stratification. The Feature 2 matrix was similar to the surrounding soil signifying limited organic preservation. With the abundance of disturbed soils above the intact cultural deposits and the geomorphic conclusions, the structural integrity of the feature was debatable. Lastly, taking the radiocarbon samples, geomorphic analysis, and the diagnostic projectile point into account, the cultural deposits may represent anywhere between 1,000 to 4,500 years of compression within $30 \mathrm{~cm}$, depending on the acceptance of the suggestion of permeation of the carbon sample from a higher elevation into the upper elevations of Feature 2. However, the testing at site 41SS164 did attempt to address the categories on the checklist of Black and Ellis's (1997) essential elements in thorough feature recording.

\section{Conclusions}

The purpose of this chapter was to analyze and synthesize data from San Saba, Mills, and Lampasas Counties to provide a wider historic context for the interpretation of site 41SS164. In addition, investigations of burned rock middens within the Llano Uplift, Lampasas Cut Plain, and Mesquite Plains subregions were utilized to gain insight into regional characteristics and patterns related to the burned rock features at site $41 \mathrm{SS} 164$. Chapter 5 discussed site 41SS164 in terms of the information that could be correlated to actual cultural activities at the site (a micro-scale intra-site analysis), while this chapter compared the data gathered from 41SS164 with other sites to see if any patterns of chronology and site typology existed that would provide clues on cultural practice and cultural change (a macro-scale inter-site analysis).
At the outset of this comparative analysis, we were operating under the understanding that prehistoric inhabitants of the tri-county research area were mobile hunter-gatherer groups that utilized a diversity of resources across the landscape. It was hoped that the study could provide insight into settlement patterns or resource utilization, and perhaps determine $41 \mathrm{SS} 164$ 's place within that patterning. However, the data set used in this analysis may just be too small to show such large scale patterning. Only 330 sites have been recorded in the tri-county research area (only 272 of which are prehistoric sites that have location information), and of those, only a handful have been investigated beyond their initial recordation. This investigation may also serve as a cautionary tale when attempting to make any interpretations using such a small data set, as the authors would prefer to wait until more data is obtained before attempting further large scale comparisons. The modest patterns laid out above may or may not hold up under further analysis. Hopefully the research above will provide some guidelines for acquiring certain kinds of data to answer specific research questions relating to subsequent broad analyses of cultural patterns and cultural change. 


\title{
Chapter 9
}

\section{Summary, Conclusions, And Recommendations}

\author{
Mindy L. Bonine
}

\section{Site Summary}

Site 41SS164 was discovered during an archaeological survey prompted by the planned replacement of the steel Pratt through truss bridge at Richland Springs Creek. TxDOT determined that additional investigations were necessary to determine if the site retained sufficient integrity and information potential to be eligible under Criterion D of the NRHP or for listing as a SAL, and SWCA was contracted by the ENV of TxDOT to conduct significance testing at site 41SS164. SWCA performed the investigations under General Services Contract \#575XXSA007, Work Authorization \#575 21 SA007, and the final report was written under General Services Contract \#577XXSA002, Work Authorization \#577 05 SA002. Texas Antiquities Permit 4156 was issued to Principal Investigator Kevin A. Miller. Project Archaeologist Mindy L. Bonine supervised the daily fieldwork, which took place June 6-13, 2006. Co-Principal Investigator Brett A. Houk assisted with the initial fieldwork setup and interpretation.

The site is located on the east bank of Richland Springs Creek and on the south side of CR 228. Cultural material was visible on the ground surface in the ROW between the gravel road and a private property fence line in the southeastern quadrant of the bridge crossing. A positive shovel test was excavated in that area, and a backhoe trench on private property to the south encountered cultural material between 30 and $70 \mathrm{cmbs}$. As the possibility of more intact prehistoric subsurface cultural material was located within the CR 228 ROW and possibly under the existing roadway, the current investigation concentrated on determining the site limits within the current ROW and systematically exploring the site deposits.

SWCA gathered information from site 41SS164 through backhoe trenching, hand excavations, special sampling, and other documentation. The volume of hand excavations totaled $3.28 \mathrm{~m}^{3}$, two backhoe trenches were excavated to a depth of 1.5-2.0 m, one 50-x-50cm column sample was placed at the eastern end of the site, and all encountered artifacts and special samples were collected.

Only one cultural component, AU 1, was documented during the testing investigations. Cultural material found above AU 1 was soon determined to be an interface deposit between the road-related deposits and the in situ alluvium deposits. This mixed fill is thought to have been brought in sometime in the historic era. AU 1 is defined as a mixed assemblage and associated cultural components within the natural stratigraphic Zone 7, which slopes downward to east to west. AU 1 contains two primary features. Feature 1 is a small discrete cluster of burned sandstone about $50 \mathrm{~cm}$ wide that was observed in the southern profile of BHT 1, and was not excavated further during the testing project. Feature 2 is a long linear fire-cracked rock zone in a sheet-like pattern on a sloping surface that was encountered in BHT 1 and TUs 1, 2, and 3.

AU 1 dates to the Early Archaic (8,800-6,000 B.P.) or Middle Archaic (6,000-4,000 B.P) period, based on the presence of one dart point, a Pandale. The Pandale point is much more common in the Lower Pecos area, where a greater number of dates are available to establish its context. The distribution is somewhat limited in central Texas. A radiocarbon sample from the same level as the Pandale point returned as date of $2900 \pm 40$ B.P., much later than the Middle Archaic, but as several lines of evidence show considerable compression of deposits within AU 1, this date may not be directly linked to the same time period as the Pandale point. 


\section{Conclusions and Recommendations}

\section{DISCUSSION OF INTEGRITY}

The tested portions of the site are in an alluvial setting that has resulted in the modest preservation of the archaeological record. Within the APE, the integrity of AU 1, dating to the Early/Middle Archaic, has been affected to a moderate degree by the deposition of the disturbed interface deposit, which appears to have caused some mixing and compression. Subsequent deposits of road fill do not appear to have affected the integrity of AU 1. However, just outside of the APE to the north, the site appears to have been negatively impacted by an erosional feature draining into Richland Springs Creek. This gully (former low water crossing) has accelerated erosion to the north of the fenceline. The extent of the cultural deposits in this area appears to be limited, though no testing was conducted. Horizon's work confirmed the site extends to the south of the existing ROW into undisturbed, adjacent floodplain for an unknown distance.

Where preserved, AU 1 contains sandstone features, artifacts (mainly debitage with some tools), and very limited faunal material and organics such as dateable carbon. The component is isolable from the earlier Pleistocene age deposits and later historic period fill sections, but the Holocene deposits in which it is contained are compressed in some areas of the site. Utilizing diagnostic tools and radiocarbon dates for interpretation, the deposits may represent the entire middle to late Holocene record within only a 30-40 $\mathrm{cm}$ zone. The implications of this for good preservation of organics, spatial patterning of features and artifacts, or isolable occupations is profound as thousands of years of time are potentially condensed into a thin zone. Although the integrity of AU 1 is considered moderate, it is not considered excellent, as the possibility for sub-divisions into distinct occupation surfaces is low given the sloping surface, compression, and variable soil aggradation across the site.

\section{SITE ELIGIBILITY}

Prior to conducting the testing, SWCA recommended that the eligibility of the site for NRHP nomination would be dependent upon levels of artifactual and contextual integrity, chronology, potential data yield, and preservation potential. The investigations, therefore, focused on two main issues: integrity and potential data yield. SWCA proposed that for the site to found significant under Criterion D, the deposits must demonstrate good integrity and adequate data yield potential to address research questions that would contribute to the understanding of the regional prehistory. It was proposed that if the site has good integrity but few artifacts, no dateable materials, no features, and poor preservation of organics, it would not be able to contribute new or important information. Similarly, if the site were found to have abundant artifacts and materials but poor archaeological integrity, it would also not be considered significant. Site eligibility would hinge on its ability to address one or more explicit, non-trivial questions about prehistory.

Research Issue 1: Integrity of the ArchaeoLogical Deposits. As mentioned above, the overall integrity of AU 1 is considered moderate to poor, though some questions remain. The investigated portion of the site did contain just enough material to establish an occupation date, as well as one reliable absolute date. However, the single cultural zone, the only cultural component that could be established at the site, cannot be subdivided into discrete occupation periods, which could be subject to specific, non-trivial, research questions. Specifically, the testing excavations failed to determine if $\mathrm{AU} 1$ is a temporally discrete occupation of this terrace in antiquity, or the result of several compressed occupation periods spanning the middle to late Holocene. The integrity of the cultural deposit has also been affected to a limited degree by the upper disturbed deposits. Finally, preservation of non-stone artifacts appears to be minimal as only one bone was recovered from the excavations.

Research Issue 2: Potential Data Yield. The notable, and somewhat unexpected, result of the testing excavations was the recovery of a large quantity of burned sandstone (181.5 kg from the hand excava- 
tion units, or about $268 \mathrm{~g}$ for every other artifact recovered). Additionally, one Pandale dart point was recovered from Feature 2 as well as several tools and two charcoal samples. Discrete features were observed (a hearth-like concentration, Feature 1, and the sheet midden, Feature 2), as well as some very limited preservation of faunal material. However, overall, the quantity and diversity of cultural material recovered from the site thus far is unimpressive, and does not constitute an assemblage of sufficient depth or breadth to answer important research questions. In other words, cultural material such as diagnostic and non-diagnostic tools and bone were all recovered from the site, but not in sufficient quantities to make any meaningful interpretations about the artifact assemblage or cultural variables such as subsistence economy, organization, or other aspects of huntergatherer lifeways.

\section{RECOMMENDATIONS}

SWCA recommends that the portion of $41 \mathrm{SS} 164$ within the APE is not eligible for NRHP listing under Criterion D, 36 CFR 60.4. Furthermore, SWCA recommends that $41 \mathrm{SS} 164$ is not eligible for SAL designation under Criteria 1 and 2 of the Rules of Practice and Procedure for the Antiquities Code of Texas, 13 TAC 26.8. Data recovery excavations are not recommended for the site within the existing ROW.

To the north of the existing ROW on private land, the site has experienced extreme erosion and is limited to a narrow strip of deposits overlooking a gully. Though no test excavations were conducted in this area north of the fence, it is likely that a portion of the site extends into this area based on BHT 2 results. However, it is the opinion of this researcher that any site deposits north of the fence would be too limited in size and content to warrant test excavations or be eligible for NRHP listing or SAL designation. To the south of the existing ROW on private land, the site undoubtedly extends for an unknown distance, as illustrated by Horizon's work. The eligibility of the portion of site 41SS164 south of the existing ROW is unknown, and therefore should be avoided or tested to make a definitive determination of significance. 



\section{Chapter 10}

\section{References Cited}

Abbott, J. A. and W. N. Trierweiler, (editors)

1995 NRHP Significance Testing of 57 Prehistoric Archeological Sites on Fort Hood, Texas. Research Report No. 34. Archeological Resource Management Series, United States Army, Fort Hood, Texas.

Ahler, S. A.

1989 Mass Analysis of Flaking Debris: Studying the Forest Rather than the Trees. In Alternative Approaches to Lithic Analysis, edited by D. Henry and G. Odell, pp. 85-119. Archaeological Papers of the American Anthropological Association, Number 1.

Andrefsky, W.

1998 Lithics: Macroscopic Approaches to Analysis. Cambridge University Press, Cambridge.

Bell, Robert E.

1958 Guide to the Identification of Certain American Indian Projectile Points. Special Bulletin, Oklahoma Anthropological Society, No. 1.

Bettinger, R. L., and M. A. Baumhoff

1982 The Numic Spread: Great Basin Cultures in Competition. American Antiquity 47(3):485503.

Binford, L. R.

1979 Organization and formation processes: looking at curated techno-logies. Journal of Anthropological Research 35:255 - 273.

1980 Willow Smoke and Dogs' Tails: HunterGatherer Settlement Systems and Archaeological Site Formation. American Antiquity 45:4-20.
Black, S. L.

1989 Central Texas Plateau Prairie. In From the Gulf to the Rio Grande: Human Adaptation in Central, South, and Lower Pecos Texas, by Thomas R. Hester, Stephen L. Black, D. Gentry Steele, Ben W. Olive, Anne A. Fox, Karl J. Reinhard, and Leland C. Bement, pp. 17-38. Research Series No. 33. Arkansas Archeological Survey, Fayetteville.

Black, S. L., and P. J. Dering

2007 Lower Pecos: Archeology. Electronic Document. http://www.texasbeyondhistory. net/pecos/archeology.html, accessed June, 2007

Black, S. L., and A. J. McGraw

1985 The Panther Springs Creek Site: Cultural Change and Continuity within the Upper Salado Creek Watershed, South-Central Texas. Archeological Survey Report No. 100. Center for Archaeological Research, The University of Texas at San Antonio.

Black, S. L., and D. C. Creel

1997 The Central Texas Burned Rock Midden Reconsidered. In Hot Rock Cooking on the Greater Edwards Plateau: Four Burned Rock Midden Sites in West Central Texas, Volume 1, by S. L. Black, L. W. Ellis, D. G. Creel, and G. T. Goode, pp. 269306. Studies in Archeology 22. Texas Archeological Research Laboratory, The University of Texas at Austin. Archeology Studies Program, Report 2. Environmental Affairs Department, Texas Department of Transportation, Austin. 
Black, S. L., and L. W. Ellis

1997 Critically Recording and Observing Burned Rock Features. In Hot Rock Cooking on the Greater Edwards Plateau: Four Burned Rock Midden Sites in West Central Texas, Volume 2, by S. L. Black, L. W. Ellis, D. G. Creel, and G. T. Goode, pp. 777-784. Studies in Archeology 22. Texas Archeological Research Laboratory, The University of Texas at Austin. Archeology Studies Program, Report 2. Environmental Affairs Department, Texas Department of Transportation, Austin.

Black, S. L., L. W. Ellis, D. G. Creel, and G. T. Goode

1997 Hot Rock Cooking on the Greater Edwards Plateau: Four Burned Rock Midden Sites in West Central Texas. Texas Archeological Research Laboratory, University of Texas at Austin. Studies in Archeology 22. Texas Department of Transportation Environmental Affairs Department. Archeology Studies Program, Report. Two Volumes.

Blair, W. F.

1950 The Biotic Provinces of Texas. The Texas Journal of Science 2(1):93-117.

Bolton, H. E.

1916 Spanish exploration in the Southwest, 1542-1706. C. Scribner's Sons, New York.

Bousman, C. B.

1992 Preliminary Oxygen-Isotope Evidence for Late Pleistocene-Early Holocene Climatic Change. Current Research in the Pleistocene 9:78-80.

1994 Central Texas Pollen Record: A Reinterpretation. Current Research in the Pleistocene 11: 79-81.

1998 Paleoenvironmental Change in Central Texas: The Palynological Evidence. Plains Anthropologist (43)164:201-219.
Burt, W. H., and R. P. Grossenheider

1976 Peterson Field Guides: Mammals. Houghton Mifflin Company, Boston and New York.

Butler, B.

2006 Investigations at the Sloan Site (41SS51) A Stratified Alluvial Terrace Site In San Saba County, Texas. Master's Thesis, Texas Tech University, Lubbock, Texas.

Butzer, K.

1982 Archaeology as Human Ecology. Cambridge University Press, Cambridge.

Campbell, R. B.

2003 Gone to Texas: A History of the Lone Star State. Oxford University Press. New York.

Camper, H. A.

1991 Pollen Analysis of Patschke Bog. Unpublished MS Thesis, Department of Botany, Texas A\&M University, Bryan, Texas.

Clark, R.

2006 Personal communication, Austin, Texas.

Clark, R., and J. D. Owens

2006 Interim Report for Archeological Survey: Cultural Resources Survey of CR 228 at the Richland Springs Creek Bridge Crossing, San Saba County, Texas. Horizon Environmental Services, Inc., Austin, Texas.

Collins, M. B. (editor)

1998 Wilson-Leonard: An 11,000-year Archeological Record of Hunter-Gatherers in Central Texas. Studies in Archeology 31. Texas Archeological Research laboratory, The University of Texas at Austin, and Archeology Studies Program Report 10, Texas Department of Transportation, Environmental Affairs Division, Austin. 
Collins, M. B.

1968 A Note on the Broad Corner-Notched Projectile Points Used In Bison Hunting in Western Texas. The Bull Roarer 3(2) 1314. The University of Texas Anthropology Society, Department of Anthropology, The University of Texas at Austin.

1990 The Archaeological Sequence at Kincaid Rockshelter, Uvalde County, Texas. Transactions of the Twenty-Fifth Regional Archeological Symposium for Southeastern New Mexico and Western Texas, pp. 25-34.

1995 Forty Years of Archeology in Central Texas. Bulletin of the Texas Archeological Society 66:361-400.

1998 Early Paleoindian Components. In WilsonLeonard: An 11,000-Year Archeological Record of Hunter-Gatherers in Central Texas, Volume I, edited and assembled by Michael B. Collins, pp. 123-159. Studies in Archeology 31. Texas Archeological Research Laboratory, The University of Texas at Austin. Archeology Studies Program, Report 10. Environmental Affairs Division, Texas Department of Transportation.

2004 Archeology in Central Texas. In Prehistory of Texas, edited by Timothy K. Perttula, pp.101-126. Texas A\&M University Press. College Station, Texas.

Collins, M. B., B. Ellis, and C. Dodt-Ellis

1990 Excavations at the Camp Pearl Wheat Site (41KR243): An Early Archaic Campsite on Town Creek, Kerr County, Texas. Studies in Archeology 6. Texas Archeological Research Laboratory, The University of Texas at Austin.
Collins, M. B., J. Guy, and S. W. Dial

1998 The Archaic Period, 8800 to 1300 B.P. In Wilson-Leonard: An 11,000Year Archeological Record of HunterGatherers in Central Texas, Volume I, edited and assembled by M. B. Collins, pp. 211-270. Studies in Archeology 31. Texas Archeological Research Laboratory, University of Texas at Austin. Archeology Studies Program, Report 10. Environmental Affairs Division, Texas Department of Transportation.

Collins, M. B., T. R. Hester, and P. J. Hedrick

1992 Engraved Cobbles from the Gault Site, Central Texas. Current Research in the Pleistocene 9:3-4.

Collins, M. B., G. L. Evans, T. N. Campbell, M. C. Winans, and C. E. Mear

1989 Clovis Occupation at Kincaid Rockshelter, Texas. Current Research in the Pleistocene $6: 3-4$.

Conant, R., and J. T. Collins

1998 Peterson Field Guides: Reptiles and Amphibians Eastern and Central North America. Third Edition. Houghton Mifflin Company, Boston and New York.

Correll, D. S., and M. C. Johnston

1979 Manual of the Vascular Plants of Texas. University of Texas at Dallas.

Cox, P. W., and P. Leslie

1999 Texas Trees: A Friendly Guide. Seventh Edition. Corona Publishing Company, San Antonio.

Creel, D.

1986 AStudyofPrehistoric Burned Rock Middens in West Central Texas. Unpublished Ph.D. dissertation. Department of Anthropology, The University of Arizona, Tucson. 
Decker, S., S. L. Black, and T. Gustavson

2000 The Woodrow Heard Site, 41UV88: A Holocene Terrace Site in the Western Balcones Canyonlands of Southwestern Texas. Studies in Archeology 33. Texas Archeological Research Laboratory, The University of Texas at Austin, and Archeology Studies Program, Report 14. Environmental Affairs Division, Texas Department of Transportation, Austin.

Dering, $\mathrm{P}$.

1999 Earth-Oven Plant Processing in Archaic Period Economies: An Example from a Semi-arid Savannah in South-Central North America. American Antiquity 64(4):659-674.

Dibble, D. S., and D. Lorrain

1968 Bonfire Shelter: A Stratified Bison Kill Site, Val Verde County, Texas. Miscellaneous Papers No. 1. Texas Memorial Museum, The University of Texas at Austin.

Diggs Jr., G. M., B. L. Lipscomb and R. J. O'Kennon

1999 Shinners and Mahler's Illustrated Flora of North Central Texas. Second Printing, 2000, with minor corrections. ed. Illustrated Texas Floras Project. Botanical Research Institute of Texas, Fort Worth.

Esary, M. E.

1982 Archaeological Geographical And Historical Comparison. Eleven NineteenthCentury Archaeological Sites Near Belleville. M.S. Thesis. Illinois State University. Normal, Illinois.

Ferring, C. R.

1986 Rates of Fluvial Sedimentation: Implications for Archaeological Variability. Geoarchaeology 1:259-74.

Foster, W. C.

1995 Spanish Expeditions into Texas, 1689 1768. University of Texas Press, Austin.
Frederick, C. D., and C. Ringstaff

1994 Lithic Resources at Fort Hood: Further Investigations. In Archeological Investigations on 571 Prehistoric Sites at Fort Hood, Bell and Coryell Counties, Texas, edited by W. N. Treirweiler. Fort Hood Archeological Resource Management Series No. 31, pp. 125-181.

Fredlund, G.

1998 Phytolith Analysis. In Wilson-Leonard, An 11,000-year Archeological Record of Hunter-Gatherers in Central Texas, Volume V: Special Studies, edited by M.B. Collins, pp. 1637-1651. Studies in Archeology 31. Texas Archeological Research Laboratory, The University of Texas at Austin. Archeology Studies Program, Report 10. Environmental Affairs Division, Texas Department of Transportation, Austin.

Garber, J. F.

1987 Transitional Archaic Structures and Activity Areas at the Zatopec Site, San Marcos, Texas. La Tierra 14(2): 19-30.

Gearhart, R. L., II

1987 The Study of Central Texas Burned Rock Middens: Their Formation, Function, and Rate of Accumulation. Unpublished Master's thesis. Department of Anthropology, The University of Missouri.

Goode, G. T.

1991 Late Prehistoric Burned Rock Middens in Central Texas. In The Burned Rock Middens of Texas: An Archeological Symposium, edited by Thomas R. Hester, pp. 71-93. Studies in Archeology 13. Texas Archeological Research Laboratory, The University of Texas at Austin.

Gould, F. W.

2002 Common Texas Grasses. Fourth Edition. Texas A\&M University Press, College Station. 
Gould, F. W., G. O. Hoffman, and C. A. Rechenthin.

1960 Vegetational Areas of Texas. Texas A\&M University, Texas Agricultural Experiment Station, Leaflet No. 492. Modified by the Texas Parks and Wildlife Department.

Graham, R. W.

1987 Late Quaternary Fauna and Paleoenvironments of the Southwestern Plains of the United States. In Late Quaternary Mammalian Biogeography and Environments of the Great Plains and Prairies, edited by R. W. Graha, H. A. Semken Jr., and M. A. Graham, pp. 24-86. Scientific Papers Volume 22. Illinois State Museum, Springfield.

Graham, R. W., and E. L. Lundelius, Jr.

1984 Coevolutionary Disequilibrium and Pleistocene Extinctions. In Quaternary Extinctions: A Prehistoric Revolution, edited by P. S. Martin and R. G. Klein, pp. 223-249. University of Arizona Press, Tucson.

Green, M.

1971 Notes of the Archeology of the Happy Patch Site, San Saba County, Texas. Bulletin of the Texas Archeological Society 42:319-333.

Green, L. M., and T. R. Hester

1973 The Finis Frost Site: A Toyah Phase Occupation of San Saba County, Central Texas. Bulletin of the Texas Archeological Society 44:69-88.

Griffith, G. E., S. A. Bryce, J. M. Omernik, J. A. Comstock, A. C. Rogers, B. Harrison, S.L. Hatch, and D. Bezanson

2004 Ecoregions of Texas (color poster with map, descriptive text, and photographs): Reston, Virginia, U.S. Geological Survey (map scale 1:2,500,000).
Hatch, S. L., K. N. Gandhi, and L. E. Brown.

1990 Checklist of the vascular plants of Texas. Texas Agricultural Experiment Station, Texas A \& M University, College Station.

Henderson, J., and G. T. Goode

1991 Pavo Real: An Early Paleoindian Site in South-Central, Texas. Current Research in the Pleistocene 8:26-28.

Henry, D. O., C. V. Haynes, and B. Bradley

1976 Quantitative Variations in Flaked Stone Debitage. Plains Anthropologist 21:5761.

Hester, T. R.

1971 Archeological Investigations at the La Jita Site, Uvalde County, Texas. Bulletin of the Texas Archeological Society 42:51-148.

1980 A Survey of Paleo-Indian Remains Along the Texas Coast. In Papers on the Archaeology of the Texas Coast, edited by L. Highley and T. R. Hester, pp. 1-22. Special Report 11. Center for Archaeological Research, The University of Texas at San Antonio.

1983 Late Paleoindian Occupations at Baker Cave, Southwestern Texas. Bulletin of the Texas Archeological Society, 53:101120.

1989 Chronological Framework for Lower Pecos Prehistory. Bulletin of the Texas Archeological Society 59 (for 1988):5364.

1991 The Burned Rock Middens of Texas: An Archeological Symposium, edited by Thomas R. Hester. Studies in Archeology 13. Texas Archeological Research Laboratory, The University of Texas at Austin.

1995 The Prehistory of South Texas. Bulletin of the Texas Archeological Society 66:427459. 
Hiscock, $\mathrm{P}$.

2002 Quantifying the size of artefact assemblages. Journal of Archaeological Science 29: 251-258.

Hoffman, J. L., L. C. Todd, and M. B. Collins 1991 Identification of Central Texas Edwards Chert at the Folsom and Lindenmeier Sites. Plains Anthropologist 36:297308.

Houk, B. A., and J. C. Lohse

1993 Archeological Investigations at the Mingo Site, Bandera County, Texas. Bulletin of the Texas Archeological Society 61:193-247.

Houk, B. A., C. B. Bousman, D. L. Nickels, and S. A. Tomka

1997a Analysis and Research Issues. In Phase II Archaeological Investigations at Lackland Air Force Base, San Antonio, Texas, by B. A. Houk and D. L. Nickels, pp. 103-146. Archaeological Survey Report, No. 264. Center for Archaeological Research, The University of Texas at San Antonio.

Houk, B. A., S. Tomka, B. Bousman, C. K. Chandler, B. Moses, M. Renner, and M. Lyons

1997b The Greenbelt Core: A Polyhedral Blade Core from San Antonio, Texas. Current Research in the Pleistocene 14:104-106.

Howard, M. A.

1983 A Quantitative Study of the Booker Site and Other Burned Rock Midden Sites of the Lake Travis Basin, Central Texas. Unpublished Master's thesis. Department of Anthropology, The University of Texas at Austin.

Huebner, J. A.

1991 Late Prehistoric Bison Populations in Central and Southern Texas. Plains Anthropologist 36(137):343-358.
Hunziker, J.

2007 Exploring Burned Rock Middens at Camp Bowie. Electronic Document. http://www. texasbeyondhistory.net/bowie/index.html, accessed June, 2007

Jelks, B.

1962 The Kyle Site: A Stratified Central Texas Aspect Site in Hill County, Texas. University of Texas Archaeology Series, No. 5.

Johnson, L., Jr.

1987 A Plague of Phases: Recent Sociocultural Taxonomy in Texas Archeology. Bulletin of the Texas Archeological Society 57:126.

1994 The Life and Times of Toyah-Culture Folk: The Buckhollow Encampment, Site 41 KM16 of Kimble County, Texas. Office of the State Archeologist Report 40. Texas Department of Transportation and Texas Historical Commission, Austin.

1995 Past Cultures and Climates at Jonas Terrace: 41ME29 of Medina County, Texas. Report No. 40. Office of the State Archeologist, Texas Historical Commission, Austin.

Johnson, L., Jr., and G. T. Goode

1994 A New Try at Dating and Characterizing Holocene Climates, as Well as Archeological Periods, on the Eastern Edwards Plateau. Bulletin of the Texas Archeolgoical Society 65:1-51.

Johnson, L., Jr., D. A. Suhm, and C. D. Tunnell 1962 Salvage Archeology of Canyon Reservoir: The Wunderlich, Footbridge, and Oblate Sites. Texas Memorial Museum Bulletin No. 5, The University of Texas at Austin. 
Katz, P. R.

1987 Archaeological Mitigation at 41BX300, Salado Creek Watershed, South-Central Texas. Archaeological Survey Report No. 130. Center for Archaeological Research, The University of Texas at San Antonio.

Kelley, J. C., and T. N. Campbell

1942 What are the Burnt Mounds of Texas? American Antiquity 7(3):319-322.

Kerr, A. C., and S. W. Dial

1998 Statistical Analysis of Unfluted Lanceolate and Early Bifurcate Stem Projectile Points. In Wilson-Leonard: An 11,000-Year Archeological Record of Hunter-Gatherers in Central Texas, Volume II, edited and assembled by Michael B. Collins, pp. 447-505. Studies in Archeology 31. Texas Archeological Research Laboratory, The University of Texas at Austin. Archeology Studies Program, Report 10. Environmental Affairs Division, Texas Department of Transportation.

Kibler, K. W., and A. M. Scott

2000 Archaic Hunters and Gatherers of the Balcones Canyonlands: Data Recovery Excavations at the Cibolo Crossing Site (41BX377), Camp Bullis Military Reservation, Bexar County, Texas. Reports of Investigations No. 126. Prewitt and Associates, Inc., Austin.

Kier, R. S., L. F. Brown, Jr., P. Harwood, and V. E. Barnes

1995 Geologic Atlas of Texas, Brownwood Sheet, Scale 1:250,000. The Bureau of Economic Geology, The University of Texas at Austin.
Kleinbach, K., G. Mehalchick, J. T. Abbott, and J. M. Quigg

1995 Other Analyses. In NRHP Significance Testing of 57 Prehistoric Archeological Sites on Fort Hood, Texas, Volume II, edited by James T. Abbott and W. Nicholas Trierweiler, pp. 765-842. Archeological Resource Management Series, Research Report No. 34. United States Army Fort Hood.

Kutac, E. A., and S. C. Caran

1994 Birds and Other Wildlife of South Central Texas. University of Texas, Austin.

Loving, S. O.

1934 A history of the Fisher-Miller land grant from 1842-1860. Unpublished Master's Thesis, Department of History, The University of Texas at Austin.

Lukowski, P. D.

1988 Archaeological Investigations at 41BX1, Bexar County, Texas. Archaeological Survey Report No. 135. Center for Archaeological Research, The University of Texas at San Antonio.

Mahoney, R. B., H. J. Shafer, S. A. Tomka, L. C. Nordt, and R. P. Mauldin

2003 Royal Coachman (41CM111): An Early Middle Archaic Site Along Cordova Creek in Comal County, Texas. Center for Archaeological Research Report No. 332. The University of Texas at San Antonio, and Archeological Studies Program, Report No. 49, Environmental Affairs Division, Texas Department of Transportation. 
Mauldin, P., D. L. Nickels, and C. J. Broehm

20032003 Archaeological Testing to Determine the National Register Eligibility Status of 18 Prehistoric Sites on Camp Bowie, Brown County, Texas. Center for Archaeological Research, The University of Texas at San Antonio Archaeological Survey Report 334. Prepared for Adjutant General's Department of Texas, Directorate of Facilities and Engineering, Environmental Branch.

McCorvie, M. R.

1987 The Davis, Baldridge, And Huggins Sites, Three Nineteenth Century Upland South Farmsteads In Perry County Illinois. Preservation Series 4. American Resources Group, Ltd. Carbondale, Illinois.

McGraw, A. J., and K. Hindes

1987 Chipped Stone and Adobe: A Cultural Resources Assessment of the Proposed Applewhite Reservoir, Bexar County, Texas. Archeological Survey Report No. 163. Center for Archeological Research, The University of Texas at San Antonio.

McKinney, W. W.

1981 Early Holocene Adaptations in Central and Southwestern Texas: The Problem of the Paleoindian-Archaic Transition. Bulletin of the Texas Archeology Society 52:91-120.

Meltzer, D. J., and M. R. Bever

1995 Paleoindians of Texas: An Update on the Texas Clovis Fluted Point Survey. Bulletin of the Texas Archeological Society 66:47-81.

Miller, G.

1987 An Introduction to English Ceramics for Archaeologists. A one-day seminar at the Second Conference on Historic Archaeology in Illinois. Midwestern Archaeological Research Center. Illinois State University. Normal, Illinois.
Miller, M., and M. Faux (editors)

1997 The New York Public Library American History Desk Reference. The Stonesong Press, Inc. and the New York Public Library, N.Y.

Murphy, V. S.

2007 Handbook of Texas Online, s.v. "San Saba County," http://www.tsha. utexas. edu/handbook/online/articles/SS/hcs5. html (accessed October 31, 2007).

Natural Heritage Policy Research Project (NHPRP)

1978 Preserving Texas' Natural Heritage. Natural Heritage Policy Research Project, Lyndon B. Johnson School of Public Affairs, the University of Texas at Austin. Policy Research Project Report Number 31.

Nickels, D. L., and R. P. Mauldin

2001 An Archaeological Survey of Twin Buttes Reservoir, Tom Green County, Texas. Archaeological Survey Report, No. 300. Center for Archaeological Research, The University of Texas at San Antonio.

Nickels, D. L., M. Lehman, C. Bousman 2003 Archaeological Evaluation of 39 Category $V$ Sites at Camp Swift, Texas 2001, SWTSU, Center for Archaeological Studies, Technical Report

Niehaus, T. F., C. L. Ripper, and V. Savage 1984 Peterson Field Guides: Southwestern and Texas Wildflowers. Houghton Mifflin Company, Boston and New York.

Niering, W. A., and N. C. Olmstead 1990 National Audubon Society Field Guide to North American Wildflowers: Eastern Region. Eleventh Edition. Alfred A. Knopf, New York. 
Nordt, L. C., T. W. Boutton, J. S. Jacob, and R. Mandel

1994 Late Quaternary Climates of Central Texas Based on the Stable Isotopic Composition of Organic Carbon. Program and Abstracts, $52^{\text {nd }}$ Plains Conference, $65^{\text {th }}$ Annual Meeting of the Texas Archeological Society, Lubbock.

Omernik, J. M.

1987 Ecoregions of the conterminous United States. Map (scale 1:7,500,000). Annals of the Association of American Geographers 77(1):118-125. Modified by the Texas Parks and Wildlife Department.

Petrides, G. A.

1979 Peterson Field Guides: A Guide to Trees and Shrubs. Second Edition. Houghton Mifflin Company, Boston and New York.

Petrides, G. A., and O. Petrides

1992 Peterson Field Guides: Western Trees. Houghton Mifflin Company, Boston and New York.

Preston, E.

1969 The McCann Site. Technological Analysis by Joel L. Shiner. Bulletin of the Texas Archeological Society 40:167-192.

Prewitt, E. R.

1981 Cultural Chronology in Central Texas. Bulletin of the Texas Archaeological Society 52:65-90.

1985 From Circleville to Toyah: Comments on Central Texas Chronology. Bulletin of the Texas Archeological Society 54:201-238.

1994 Burned Rock Middens: A Summary of Previous Investigations and Interpretations. In The Burned Rock Middens of Texas: An Archeology Symposium, edited by T. R. Hester, pp. 25-32. Studies in Archeology 13. Austin: Texas Archeological Research Laboratory, University of Texas at Austin.
1995 Distributions of Typed Projectile Points in Texas. Bulletin of the Texas Archaeological Society 66:83-173.

Ricklis, R. A.

1992 The Spread of Late Prehistoric Bison Hunting Complex: Evidence from the South-Central Coastal Prairie of Texas. Plains Anthropologist 37(140):261-273.

1994 Toyah Components: Evidence for Occupation in the Project Area during the Latter Part of the Late Prehistoric. In Archaic and Late Prehistoric Human Ecology in the Middle Onion Creek Valley, Hays County, Texas. Studies in Archeology 19. Texas Archeological Research Laboratory, The University of Texas at Austin.

Ricklis, R. A., M. D. Blum, and M. B. Collins 1991 Archaeological Testing at the Vera Daniels Site (41TV1364), Zilker Park, Austin, Texas. Studies in Archeology 12. Texas Archeological Research Laboratory. The University of Texas at Austin.

Robinson, R. L.

1982 Biosilica Analysis of Three Prehistoric Archaeological Sites in the Choke Canyon Reservoir, Live Oak County, Texas: Preliminary Summary of Climatic Implications. In Archaeological Investigations at Choke Canyon Reservoir, South Texas: The Phase I Findings, edited by G. D. Hall, S. L. Black, and C. Graves, pp. 597-610. Choke Canyon Series, No. 5. Center for Archaeological Research, The University of Texas at San Antonio.

Schmidly, D. J.

1983 Texas Mammals East of the Balcones Fault Zone. Texas A\&M University Press, College Station. 
Sellards, E. H., W. S. Adkins, and F. B. Plumber 1932 The Geology of Texas, Volume I, Stratigraphy. The University of Texas Bulletin No. 3232. Bureau of Economic Geology, The University of Texas at Austin.

Shafer, H. J.

1971 Late Prehistoric of Central Texas: 500 B.C. to A.D. 1700. Paper given at annual meeting, Texas Academy of Science, Nacogdoches.

1986 Ancient Texans: Rock Art and Lifeways Along the Lower Pecos. Texas Monthly Press, Austin.

Simpson, B. J.

1988 AField Guide to Texas Trees. Texas Monthly Field Guide Series. Texas Monthly Press, Austin, Texas.

Sonderman, R. C.

1979 Archaeological Explorations of the Jesse Lindall and Twiss Hill Historic Sites St. Clair County Illinois. M.S. Thesis. Illinois State University. Normal, Illinois.

Sorrow, W. M.

1969 Archeological Investigations at the John Ischy Site: A Burned Rock Midden in Williamson County, Texas. Papers of the Texas Archeological Salvage Project No. 18. The University of Texas at Austin.

Sorrow, W. M., H. J. Shafer, and R. E. Ross

1967 Excavations at Stillhouse Hollow Reservoir. Papers of the Texas Archeological Salvage Project, Project 11. Austin.

Spearing, D.

1991 Roadside Geology Series: Roadside Geology of Texas. Mountain Press Publishing Company. Missoula, MT.
Stahle, D. W., and J. E. Dunn

1982 An Analysis and Application of the Size Distribution of Waste Flakes from the Manufacturing of Bifacial Stone Tools. World Archaeology 14:84-97.

Stein, J., D. Binion, and R. Acciavatti

2003 Field Guide to Native Oak Species of Eastern North America. U. S. Forest Service, Forest Health Technology Enterprise Team, Morgantown, WV.

Story, D. A.

1985 Adaptive Strategies of Archaic Cultures of the West Gulf Coastal Plain. In Prehistoric Food Production in North America, edited by R. I. Ford, pp. 19-56. Anthropological Papers 75. Museum of Anthropology, University of Michigan, Ann Arbor.

1990 Cultural History of the Native Americans. In The Archeology and Bioarcheology of the Gulf Coastal Plain, by Dee Ann Story, Janice A. Guy, Barbara A. Burnett, Martha Doty Freeman, Jerome C. Rose, D. Gentry Steele, Ben W. Olive, and Karl J. Reinhard, pp. 163-366. Research Series No. 38. Arkansas Archeological Survey, Fayetteville.

Suhm, D. A.

1960 A Review of Central Texas Archeology. Bulletin of the Texas Archeological Society 29:63-107.

Suhm, D. A., A.D. Kreiger, and E. B. Jelks

1954 An Introductory Handbook of Texas Archeology. Bulletin of the Texas Archeological Society, Vol. 25.

Takac, P. R.

1991 Underwater Excavations at Spring Lake: A Paleoindian Site in Hays County, Texas. Current Research in the Pleistocene 8:46-48. 
Taylor, R. (editor)

1996 The New Handbook of Texas in Six Volumes. The Texas State Historical Association, Austin.

Thoms, A. V., and R. D. Mandel

1992 The Richard Beene Site:A Deeply Stratified Paleoindian to Late Prehistoric Occupation in South-Central Texas. Current Research in the Pleistocene 9:42-44.

Thoms, A. V., D. D. Kuehn, B. W. Olive, J. E. Dockall, P. A. Clabaugh, and R. Mandel

1996 Early and Middle Holocene Occupations at the Richard Beene Site: The 1995 Southern Texas Archaeological Association Field School Project. La Tierra 23(4):8-36.

Toomey, R. S., III

1993 Late Pleistocene and Holocene Faunal and Environmental Changes at Hall's Cave, Kerr County, Texas. Vols. 1 and 2 Unpublished Ph.D. dissertation, Department of Geology, The University of Texas at Austin.

Toomey, R. S., III, and T. W. Stafford, Jr.

1994 Paleoenvironmental and Radiocarbon Study of the Deposits from Hall's Cave, Kerr County, Texas. Program and Abstracts, $52^{\text {nd }}$ Plains Conference, $65^{\text {th }}$ Annual Meeting of the Texas Archeological Society, Lubbock.

Trierweiler, W. N. (editor)

1994 Archeological Investigations on 571 Prehistoric sites at Fort Hood, Bell, and Coryell Counties, Texas. Research Report No. 31. Archeological Resource Management Series, United States Army, Fort Hood, Texas.

1996 Archeological Testing at Fort Hood 19941995. Research Report No. 35, Vols. 1 and 2. Archeological Resource Management Series, United States Army, Fort Hood, Texas.
Trigger, B. G.

1967 Settlement-its goals and promise. American Antiquity 32:149-60.

Tunnell, C.

1978 The Gibson Lithic Cache from West Texas. Office of the State Archaeologist, Texas Historical Commission, Office of the State Archaeologist Report 30, Austin, Texas.

Turner, E. S., and T. R. Hester

2002 A Field Guide to Stone Artifacts of Texas Indians. Texas Monthly Field Guide Series, Gulf Publishing, Houston.

Turner, B. L., H. Nichols, G. Denny and O. Doron 2003 Atlas of the Vascular Plants of Texas, Volume 1:Dicots. Sida, Botanical Miscellany, Number 24 Volume 1: Dicots. BRIT Press, Fort Worth.

Vierra, B. J.

1997 Lithic Analysis. In A Presidio Community on the Rio Grande: Phase III Testing and Historical Research at San Elizario, Texas, edited by B. J. Vierra, J. Piper, and R. C. Chapman, pp. 353-362. OCA/UNM Report No. 185-545. Albuquerque, Office of Contract Archeology, University of New Mexico.

Vines, R. A.

1997 Trees of Central Texas. Fifth Edition. University of Texas Press, Austin.

Voellinger, L. R., and R. L. Gearhart

1987 Mitigation of Impacts at Three Burned Rock Midden Sites in the Block House Creek Development Williamson County, Texas. Document No. 860188. Espey, Huston and Associates, Inc. Austin.

Wandsnider, L.

1997 The Roasted and the Boiled: Food Composition and Heat Treatment with Special Emphasis on Pit-Hearth Cooking. Journal of Anthropological Archaeology 16:1-48. 


\section{0-12 Chapter 10}

Weir, F. A.

1976 The Central Texas Archaic. Ph.D.

Dissertation, Department of Anthropology, Washington State University, Pullman.

Wesolowsky, A. B., T. R. Hester, and D. R. Brown

1976 Archeological Investigations at the Jetta Court Site (41TV151), Travis County, Texas, Bulletin of the Texas Archeological Society 47:25-88

Willey, G. R., and P. Phillips

1958 Method and Theory in American Archaeology. University of Chicago Press, Chicago.

Wilson, E. W.

1930 Burnt Rock Mounds of Southwest Texas. Bulletin of the Texas Archaeological and Paleontological Society 2:59-63.

Winterhalder, B., and E. A. Smith (editors)

1981 Hunter-Gatherer Foraging Strategies. University of Chicago Press.

Wormser, A. J., and S. Sullo-Prewitt

2001 Cultural Resources Inventory of Camp Bowie, Brownwood, Texas. Center for Archaeological Research, Archaeological Survey Report 317. The University of Texas at San Antonio.

Woodburn, J.

1982 Egalitarian Societies. Man 17:431-451. 
Appendix A: Materials Recovered 

Table A.1. Materials Recovered From Test Unit 1.

\begin{tabular}{|c|c|c|c|c|c|c|c|c|c|c|c|c|c|c|c|c|}
\hline \multirow[b]{2}{*}{ Context } & \multirow[b]{2}{*}{ Level } & \multirow[b]{2}{*}{ Feature } & \multicolumn{12}{|c|}{ Artifact Counts } & \multicolumn{2}{|c|}{ FCR } \\
\hline & & & Bolt & $\begin{array}{c}\text { Plastic/ } \\
\text { Whiteware }\end{array}$ & $\begin{array}{l}\text { Bottle } \\
\text { Glass }\end{array}$ & \begin{tabular}{|l} 
Charcoal \\
Samples
\end{tabular} & $\begin{array}{c}\text { Matrix } \\
\text { Samples }\end{array}$ & $\begin{array}{l}\text { Dart } \\
\text { Points }\end{array}$ & $\begin{array}{c}\text { Bifaces in } \\
\text { all }\end{array}$ & $\begin{array}{c}\text { Unifacial } \\
\text { Tools }\end{array}$ & $\begin{array}{l}\text { Ground- } \\
\text { stone }\end{array}$ & $\begin{array}{l}\text { Flake } \\
\text { Core }\end{array}$ & Debitage & Faunal & \# & kg \\
\hline Disturbed Interface & 2 & & 1 & & 1 & & & & & & & & 12 & & 3 & 0.90 \\
\hline Disturbed Interface & 3 & & & & & & & & 1 & & & & 54 & & 92 & 3.50 \\
\hline Disturbed Interface & 4 & & & & & 1 & & & & & & & 18 & & 85 & 13.50 \\
\hline Disturbed Interface & 5 & & & & & & & & & & & & 51 & & 49 & 3.10 \\
\hline Intact Cultural & 6 & 2 & & & & & & & & & & & 37 & & 37 & 1.50 \\
\hline Intact Cultural & 7 & 2 & & & & & & & 1 & 1 & 2 & & 24 & & 89 & 17.20 \\
\hline Intact Cultural & 8 & 2 & & & & & & & 1 & & & & 51 & & 122 & 9.70 \\
\hline Intact Cultural & 9 & 2 & & & & & & & & & & & 20 & & 54 & 1.70 \\
\hline Intact Cultural & 10 & 2 & & & & & & & & & & & 5 & & 3 & 0.10 \\
\hline Intact Cultural & 11 & 2 & & & & & & & & & & & 4 & & 17 & 0.40 \\
\hline
\end{tabular}

Table A.2. Materials Recovered From Test Unit 2.

\begin{tabular}{|c|c|c|c|c|c|c|c|c|c|c|c|c|c|c|c|c|}
\hline \multirow[b]{2}{*}{ Context } & \multirow[b]{2}{*}{ Level } & \multirow[b]{2}{*}{ Feature } & \multicolumn{12}{|c|}{ Artifact Counts } & \multicolumn{2}{|c|}{ FCR } \\
\hline & & & Bolt & $\begin{array}{c}\text { Plastic/ } \\
\text { Whiteware }\end{array}$ & $\begin{array}{l}\text { Bottle } \\
\text { Glass }\end{array}$ & $\begin{array}{l}\text { Charcoal } \\
\text { Samples }\end{array}$ & $\begin{array}{c}\text { Matrix } \\
\text { Samples }\end{array}$ & $\begin{array}{c}\text { Dart } \\
\text { Points }\end{array}$ & $\begin{array}{c}\text { Bifaces in } \\
\text { all }\end{array}$ & $\begin{array}{l}\text { Unifacial } \\
\text { Tools }\end{array}$ & $\begin{array}{l}\text { Ground- } \\
\text { stone }\end{array}$ & $\begin{array}{l}\text { Flake } \\
\text { Core }\end{array}$ & Debitage & Faunal & \# & kg \\
\hline Disturbed Interface & 1 & & & 1 & 1 & & & & & & & & 50 & & 12 & 1.1 \\
\hline Disturbed Interface & 2 & & & & & 1 & & & 1 & & & 1 multi-dir & 20 & & 73 & 10 \\
\hline Disturbed Interface & 3 & & & & & & & & 1 & & & & 59 & 1 shell frag & 42 & 3.7 \\
\hline Intact Cultural & 4 & 2 & & & & & & & & 1 & & & 70 & & 40 & $\begin{array}{l}1.8 \\
\end{array}$ \\
\hline Intact Cultural & 5 & 2 & & & & & & & 1 & & & & 35 & & 77 & 4.2 \\
\hline Intact Cultural & 6 & 2 & & & & 1 & 1 & 1 Pandale & & & & & 37 & & 403 & 76.2 \\
\hline
\end{tabular}

Table A.3. Materials Recovered From Test Unit 3.

\begin{tabular}{|c|c|c|c|c|c|c|c|c|c|c|c|c|c|c|c|c|}
\hline \multirow[b]{2}{*}{ Context } & \multirow[b]{2}{*}{ Level } & \multirow[b]{2}{*}{ Feature } & \multicolumn{12}{|c|}{ Artifact Counts } & \multicolumn{2}{|c|}{ FCR } \\
\hline & & & Bolt & $\begin{array}{c}\text { Plastic/ } \\
\text { Whiteware }\end{array}$ & $\begin{array}{l}\text { Bottle } \\
\text { Glass }\end{array}$ & $\begin{array}{l}\text { Charcoal } \\
\text { Samples }\end{array}$ & $\begin{array}{c}\text { Matrix } \\
\text { Samples }\end{array}$ & $\begin{array}{l}\text { Dart } \\
\text { Points }\end{array}$ & $\begin{array}{c}\text { Bifaces in } \\
\text { all }\end{array}$ & $\begin{array}{c}\text { Unifacial } \\
\text { Tools }\end{array}$ & $\begin{array}{l}\text { Ground- } \\
\text { stone }\end{array}$ & $\begin{array}{l}\text { Flake } \\
\text { Core }\end{array}$ & Debitage & Faunal & \# & kg \\
\hline Intact Cultural & 2 & 2 & & & & 1 & 1 & & 1 & & & & 19 & 14 bone & 188 & 28.9 \\
\hline
\end{tabular}

Table A.4. Materials Recovered From Test Unit 4.

\begin{tabular}{|c|c|c|c|c|c|c|c|c|c|c|c|c|c|c|c|c|}
\hline \multirow[b]{2}{*}{ Context } & \multirow[b]{2}{*}{ Level } & \multirow[b]{2}{*}{ Feature } & \multicolumn{12}{|c|}{ Artifact Counts } & \multicolumn{2}{|c|}{ FCR } \\
\hline & & & Bolt & $\begin{array}{c}\text { Plastic/ } \\
\text { Whiteware }\end{array}$ & $\begin{array}{l}\text { Bottle } \\
\text { Glass }\end{array}$ & $\begin{array}{l}\text { Charcoal } \\
\text { Samples }\end{array}$ & $\begin{array}{c}\text { Matrix } \\
\text { Samples }\end{array}$ & Dart Points & $\begin{array}{c}\text { Bifaces in } \\
\text { all }\end{array}$ & $\begin{array}{c}\text { Unifacial } \\
\text { Tools }\end{array}$ & $\begin{array}{l}\text { Ground- } \\
\text { stone }\end{array}$ & Flake Core & Debitage & Faunal & \# & $\mathbf{k g}$ \\
\hline Intact Cultural & 1 & 2 & & & & & & & & & & & 27 & & 52 & 3.4 \\
\hline Intact Cultural & 2 & 2 & & & & & & & & & & & 8 & & 8 & 0.2 \\
\hline
\end{tabular}


Table A.5. Materials Collected From the Column Sample.

\begin{tabular}{|c|c|c|c|c|c|c|c|c|c|c|c|c|c|c|c|c|}
\hline \multirow[b]{2}{*}{ Context } & \multirow[b]{2}{*}{ Level } & \multirow[b]{2}{*}{ Feature } & \multicolumn{12}{|c|}{ Artifact Counts } & \multicolumn{2}{|c|}{ FCR } \\
\hline & & & Bolt & $\begin{array}{c}\text { Plastic/ } \\
\text { Whiteware }\end{array}$ & $\begin{array}{l}\text { Bottle } \\
\text { Glass }\end{array}$ & $\begin{array}{l}\text { Charcoal } \\
\text { Samples }\end{array}$ & $\begin{array}{c}\text { Matrix } \\
\text { Samples }\end{array}$ & $\begin{array}{l}\text { Dart } \\
\text { Points }\end{array}$ & $\begin{array}{c}\text { Bifaces in } \\
\text { all }\end{array}$ & $\begin{array}{c}\text { Unifacial } \\
\text { Tools }\end{array}$ & $\begin{array}{l}\text { Ground- } \\
\text { stone }\end{array}$ & $\begin{array}{l}\text { Flake } \\
\text { Core }\end{array}$ & Debitage & Faunal & $\#$ & kg \\
\hline Intact Cultural & 1 & 2 & & & & & & & & & & & 6 & & 5 & 0.3 \\
\hline Intact Cultural & 2 & 2 & & & & & & & & & & & 1 & & & \\
\hline Intact Cultural & 3 & 2 & & & & & & & & & & & 1 & & 1 & 0.1 \\
\hline Intact Cultural & 5 & 2 & & & & & & & & & & & 1 & & & \\
\hline
\end{tabular}

Table A.6. Materials Collected From the BHT 1 Profile.

\begin{tabular}{|c|c|c|c|c|c|c|c|c|c|c|c|c|c|c|c|}
\hline \multirow[b]{2}{*}{ Context } & \multirow[b]{2}{*}{ Level } & \multirow[b]{2}{*}{ Feature } & \multicolumn{13}{|c|}{ Artifact Counts } \\
\hline & & & Bolt & $\begin{array}{c}\text { Plastic/ } \\
\text { Whiteware }\end{array}$ & $\begin{array}{l}\text { Bottle } \\
\text { Glass }\end{array}$ & $\begin{array}{l}\text { Charcoal } \\
\text { Samples }\end{array}$ & $\begin{array}{c}\text { Matrix } \\
\text { Samples }\end{array}$ & Dart Points & $\begin{array}{c}\text { Bifaces in } \\
\text { all }\end{array}$ & $\begin{array}{c}\text { Unifacial } \\
\text { Tools }\end{array}$ & $\begin{array}{l}\text { Ground- } \\
\text { stone }\end{array}$ & Flake Core & $\begin{array}{l}\text { Utilized } \\
\text { Flakes }\end{array}$ & Debitage & Faunal \\
\hline Roadfill & 64 (cmbs) & & & & & & & & 1 & & & & & & \\
\hline Intact Cultural & 120 (cmbs) & 2 & & & & & & & & & & & 1 & & \\
\hline Intact Cultural & 126 (cmbs) & 2 & & & & & & & & 1 & & & & & \\
\hline Intact Cultural & 130 (cmbs) & 2 & & & & & & & & 1 & & & & & \\
\hline
\end{tabular}


Appendix B: Radiocarbon Results 



$\begin{array}{cc}\text { Measured } & 13 \mathrm{C} / 12 \mathrm{C} \\ \text { Radiocarbon Age } & \text { Ratio }\end{array}$

Conventional Radiocarbon Age ${ }^{*}$ )

Beta - 231560

SAMPLE : Lot 6-S1 41SS164

$$
270+/-40 \text { BP }
$$

-25.9 o/oo

$260+/-40$ BP

ANALYSIS : AMS-Standard delivery

MATERIAL/PRETREATMENT : (charred material): acid/alkali/acid

2 SIGMA CALIBRATION :

Cal AD 1520 to 1590 (Cal BP 430 to 360) AND Cal AD 1620 to 1670 (Cal BP 330 to 280)

Cal AD 1770 to 1800 (Cal BP 180 to 150) AND Cal AD 1940 to 1950 (Cal BP 10 to 0)

Beta - 231561

$2920+/-40$ BP

-26.3 o/oo

$2900+/-40$ BP

SAMPLE : Lot 19-S2 41SS164

ANALYSIS : AMS-Standard delivery

MATERIAL/PRETREATMENT : (charred material): acid/alkali/acid

2 SIGMA CALIBRATION : $\quad$ Cal BC 1250 to 1240 (Cal BP 3200 to 3190) AND Cal BC 1220 to 980 (Cal BP 3170 to 2930)

Beta - 231562

$200+/-40$ BP

-25.3 o/oo

$200+/-40$ BP

SAMPLE : Lot 24-S3 41SS164

ANALYSIS : AMS-Standard delivery

MATERIAL/PRETREATMENT : (charred material): acid/alkali/acid

2 SIGMA CALIBRATION : $\quad$ Cal AD 1640 to 1700 (Cal BP 310 to 260) AND Cal AD 1720 to 1820 (Cal BP 220 to 140)

Cal AD 1920 to 1950 (Cal BP 30 to 0)

Beta - 231563

$240+/-40$ BP

-25.6 o/oo

$230+/-40$ BP

SAMPLE : Lot 10-S6 41SS164

ANALYSIS : AMS-Standard delivery

MATERIAL/PRETREATMENT : (charred material): acid/alkali/acid

2 SIGMA CALIBRATION : $\quad$ Cal AD 1540 to 1540 (Cal BP 420 to 400) AND Cal AD 1630 to 1680 (Cal BP 320 to 270)

Cal AD 1740 to 1810 (Cal BP 210 to 140) AND Cal AD 1930 to 1950 (Cal BP 20 to 0) 


\section{CALIBRATION OF RADIOCARBON AGE TO CALENDAR YEARS}

(Variables: C $13 /$ C $12=-25.9: 1$ ab. mult=1)

Laboratory number: Beta-231560

Conventional radiocarbon age: $260 \pm 40$ B P

2 Sigma calibrated results: C al AD 1520 to 1590 (C al BP 430 to 360 ) and

(95\% probability) C al AD 1620 to 1670 (C al BP 330 to 280 ) and

$C$ al AD 1770 to 1800 (C al BP 180 to 150$)$ and

$C$ al AD 1940 to 1950 (C al BP 10 to 0 )

Intercept data

Intercept of radiocarb on age

with calibration curve: Cal AD 1650 (Cal B P 300 )

1 Sigma calibrated result: Cal AD 1640 to 1660 (Cal BP 310 to 290)

(68\% probability)

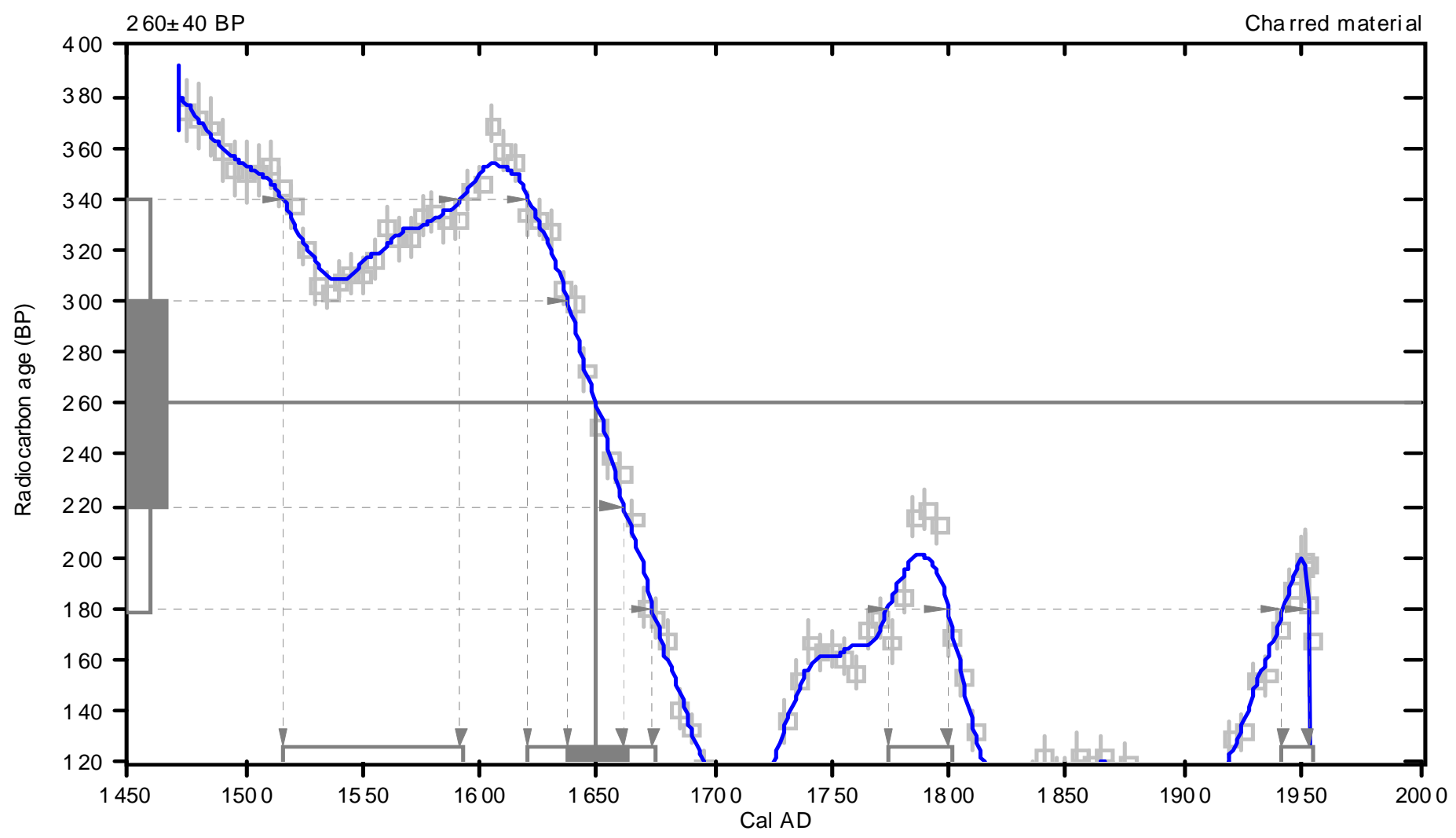

References:

Datab ase used INTC ALO 4

Ca lib ratio $n$ Da ta ba se

IN TC AL 4 Radiocarb on A ge Ca lib ration

IntC al04: Calibration Iss ue of Radiocarbon (Volume 4 6, nr 3, 2004 ).

Math ematics

A S implified A pproach to Ca librating C14 Dates

Ta Ima, A. S., Vo gel, J. C., 1993 , Rad iocarbon 35 (2), p31 7-3 22 


\section{CALIBRATION OF RADIOCARBON AGE TO CALENDAR YEARS}

(Variables: C $13 /$ C $12=-26.3:$ lab. mult=1)

Laboratory number: Beta-231561

C onventional radio carbon age: $2900 \pm 40 \mathrm{BP}$

2 Sigma calibrated results: C al BC 1250 to 1240 (Cal BP 3200 to 3190 ) and

(95\% probability) C al BC 1220 to 980 (Cal BP 3170 to 2930 )

Intercept data

Intercept of radiocarb on age

with calibration curve: Cal BC 1080 (Cal B P 303 0)

1 Sigma calibrated result: Cal BC 1130 to 1010 (Cal BP 3080 to 2960)

(68\% probability)

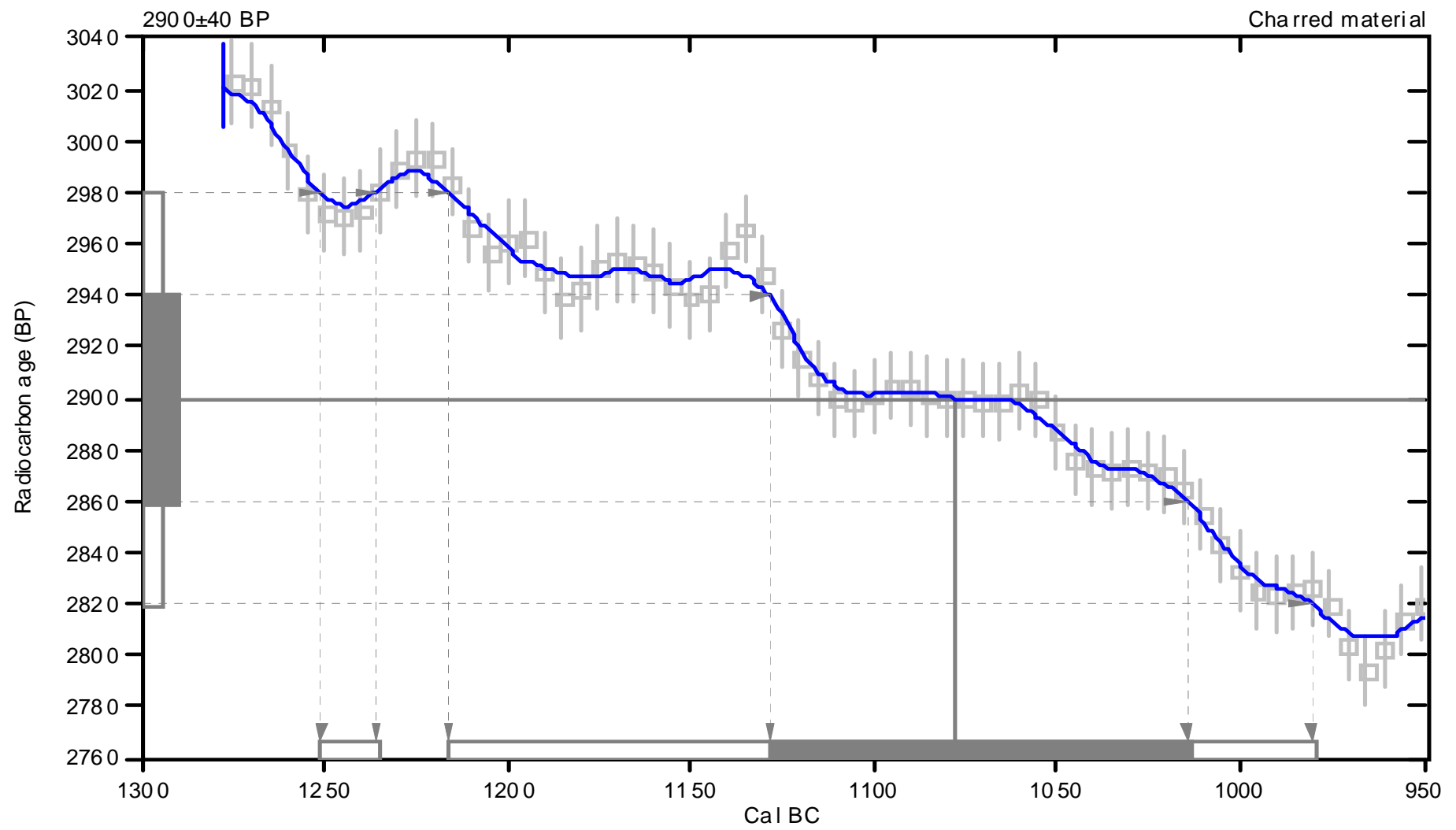

References:

Database used INT C ALO 4

Ca lib ra tio n Da ta ba se

IN TC ALO 4 Ra dioca rb on Age Ca lib ration

IntC al04: Calibration Issue of Radiocarbon (Volume 4 6, $n \mathrm{r} \mathrm{3,} 2004$ ).

Mathematics

A Simplified Approach to Ca librating C14 Dates

Ta lma, A. S., Vo gel, J. C., 1993 , Rad iocarbon 35(2), p31 7-322 


\section{CALIBRATION OF RADIOCARBON AGE TO CALENDAR YEARS}

(Variables: C $13 /$ C $12=-25.3: 1$ ab. mult=1)

Laboratory number： Beta-231562

Conventional radiocarbon age: $200 \pm 40$ B P

2 Sigma calibrated results: C al AD 1640 to 1700 (C al BP 310 to 260) and

(95\% probability) C al AD 1720 to 1820 (C al BP 220 to 140) and

C al AD 1920 to 1950 (C al BP 30 to 0 )

Intercept data

Intercepts of radiocarbon age w ith calibration curve:

Cal AD 1670 (Cal B P 280 ) and

Cal AD 1780 (Cal BP 160) and

Cal AD 1790 (Cal BP 160)

1 Sigma calibrated results: Cal AD 1660 to 1680 (Cal BP 290 to 270 ) and

(68\% probability) Cal AD 1740 to 1800 (Cal BP 210 to 150) and Cal AD 1940 to 1950 (Cal BP 20 to 0)

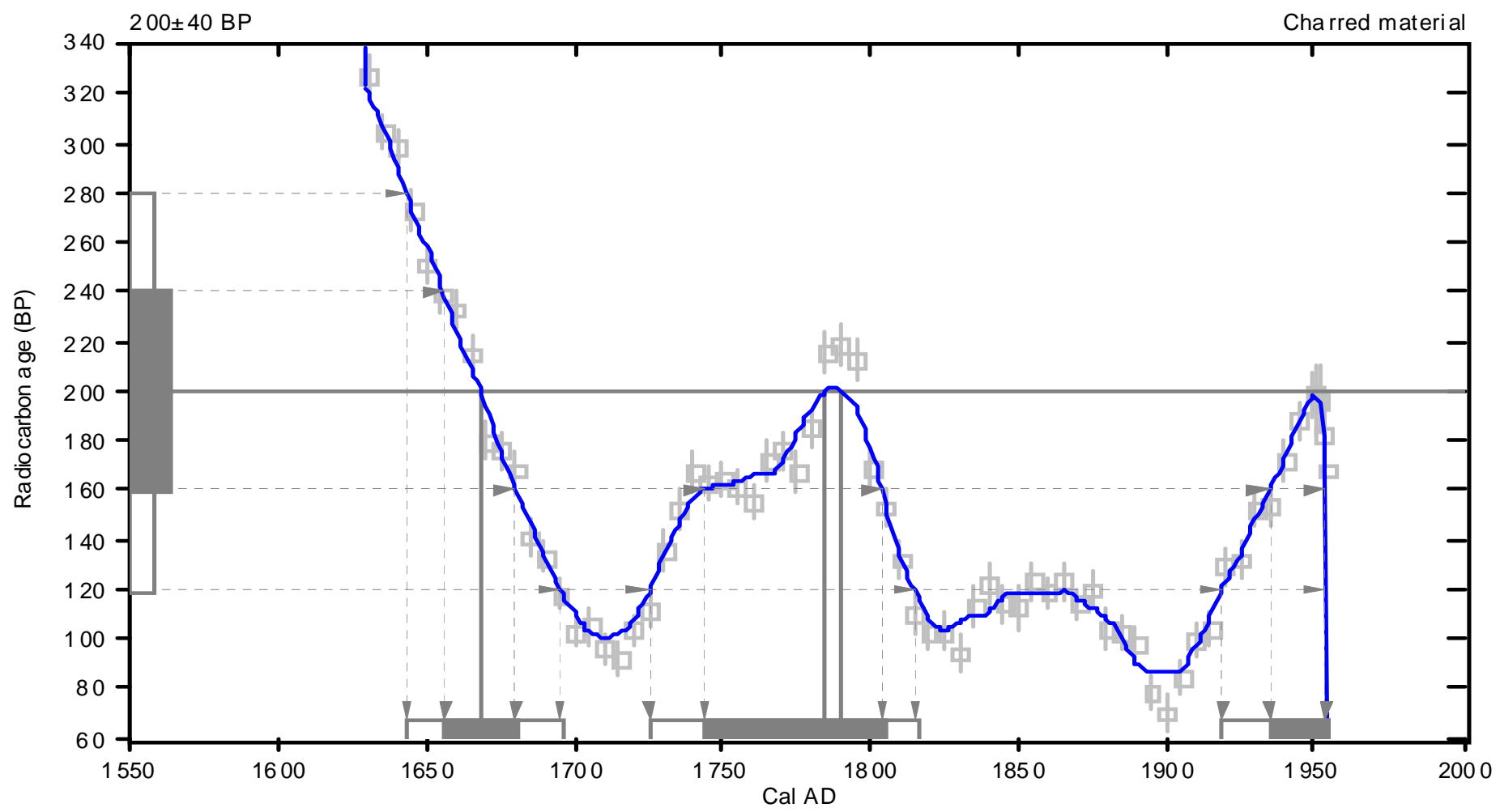

References:

Datab as e used INT C ALO 4

Ca lib ra tion Da ta ba se

IN TC AL 04 Radioca rb on Age Ca lib ration

IntC al04: Calibration Issue of Radiocarbon (Volume 4 6, $\mathrm{nr}$ 3, 2004 ).

Mathematics

A Simplified Approach to Ca librating C14 Dates

Ta lma, A. S., Vo gel, J. C., 1993 , Rad iocar bo n 35(2), p31 7-3 22 


\section{CALIBRATION OF RADIOCARBON AGE TO CALENDAR YEARS}

(Variables: C $13 /$ C $12=-25.6:$ lab. mult $=1$ )

Laboratory number: Beta-231563

C onventional radiocarbon age: $230 \pm 40$ B P

2 Sigma calibrated results: C al AD 1540 to 1540 (C al BP 420 to 40 0) and

(95\% probability) C al AD 1630 to 1680 (C al BP 320 to 270 ) and

$C$ al AD 1740 to 1810 (C al BP 210 to 140) and

$C$ al AD 1930 to 1950 (C al BP 20 to 0 )

Intercept data

Intercept of radiocarb on age

w ith calib ration curve:

Cal AD 1660 (Cal B P 290)

1 Sigma calibrated results: Cal AD 1650 to 1670 (Cal BP 300 to 280) and

(68\% probability) Cal AD 1780 to 1800 (Cal BP 170 to 150 ) and

Cal AD 1950 to 1950 (Cal BP 0 to 0)

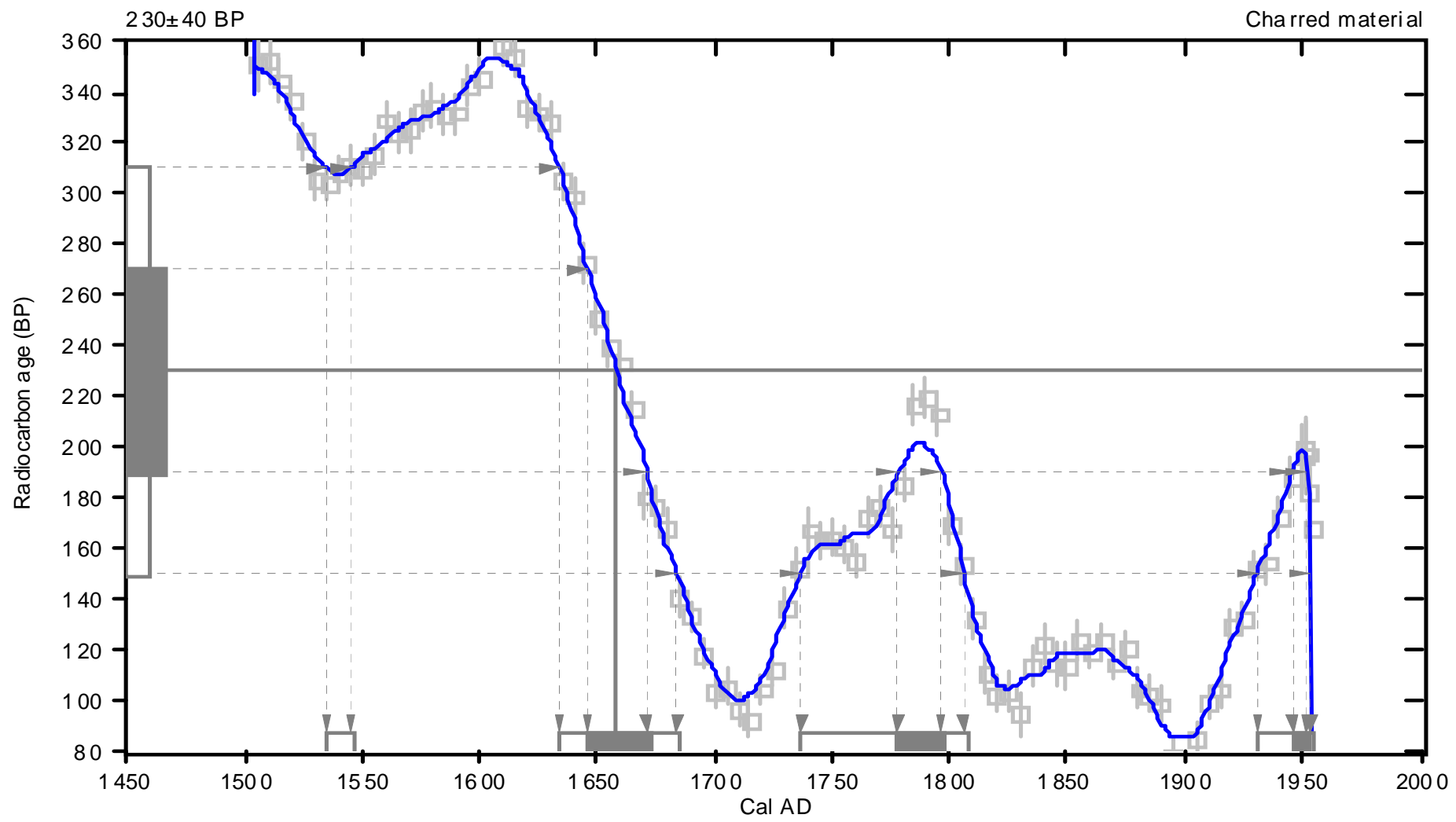

References:

Datab ase used INTC ALO 4

Ca lib ratio $n$ Da ta ba se

IN TC AL 4 Radiocarb on Age Calib ration

IntC al04: Calibration Issue of Radiocarbon (Volume 4 6, n r 3, 200 4).

Math ematics

A S implified A pproach to Ca librating C14 Dates

Ta lma, A. S., Vo gel, J. C., 1993 , Radiocarbon 35 (2), p31 7-3 22 



\section{Appendix C: Macrobotanical Results}





\title{
FLORA FROM \\ 41SS164, \\ SAN SABA COUNTY, TEXAS
}

June 29, 2007

\author{
Prepared for: \\ Laura I. Acuña, Laboratory Director \\ SWCA Environmental Consultants, Inc. \\ Building 1, Suite 110 \\ Monterey Oaks Blvd. \\ Austin, Texas 78749
}

Prepared by:

Leslie L. Bush, Ph.D., R.P.A. Macrobotanical Analysis

1807 W. Slaughter Ln. \#200-470

Austin, Texas 78748 
Four radiocarbon samples and two flotation samples taken during testing of 41SS164 were submitted for analysis. Both flotation samples come from Feature 2, a linear firecracked rock zone believed to date to the Early or Middle Archaic.

\section{Methods}

Radiocarbon samples. Radiocarbon samples were dried at the Macrobotanical Analysis laboratory, then snapped in half to reveal clean transverse sections and examined under a stereoscopic microscope at 28-180 X magnification. Some samples were further broken so that tangential sections could be examined for ray seriation and internal vessel anatomy. All work was accomplished using freshly cleaned glassware by an analyst wearing latex gloves. Samples were weighed, labeled, and returned to their original containers when identification was complete.

Flotation samples. Flotation samples were processed at SWCA Environmental Consultants, Inc. Both light and heavy fractions were submitted for sorting and analysis. Samples were sorted in the author's laboratory in Manchaca. Flotation heavy fractions were examined under a stereoscopic microscope at 7-28 X magnification. All carbonized plant material was removed and added to the light fraction. Each flotation light fraction was then weighed on an electronic balance with a capacity of $200 \times 0.01 \mathrm{~g}$ before being size-sorted through a stack of geologic mesh with openings of $2 \mathrm{~mm}, 1.4 \mathrm{~mm}$, and 0.71 $\mathrm{mm}$. Materials in the $>2 \mathrm{~mm}$ size fraction were completely sorted, and all carbonized botanical remains were counted, weighed, recorded, and labeled. All materials in the $>2$ $\mathrm{mm}$ size fraction other than carbonized plants are referred to as "contamination" in Table C. 3 and on laboratory forms. At 41SS164, contamination consisted of uncarbonized flora. Materials that fell through the $2 \mathrm{~mm}$ mesh, referred to as "residue," were examined under a stereoscopic microscope at 7-45 x magnification for carbonized botanical remains. Only wood charcoal flecks were present, and they were not removed from residue. The presence of uncarbonized taxa in the residue was also recorded on laboratory forms, but these materials were not removed from residue. Wood charcoal $>2 \mathrm{~mm}$ was identified as described for the radiocarbon samples except that the specimens were handled directly (i.e., without gloves) to aid in the production of clean surfaces in these much smaller wood charcoal fragments.

Botanical materials were identified to the lowest possible taxonomic level by comparison to materials in the author's comparative collection and through the use of standard reference works (e.g., Davis 1993; Hoadley 1990; Martin and Barkley 1961; Musil 1963; Panshin and deZeeuw 1980; Schopmeyer 1974). In some cases botanical remains could be identified to the level of the species through positive identification or elimination of other members of the genus (e.g., Quercus fusiformis). Most commonly botanical materials were identified to the level of genus, but sometimes only family identification was possible. Botanical nomenclature and common names follow Diggs and colleagues (1999) except in the cases where the name in archeological use differs significantly from the name used in that source. 


\section{Results}

Identifications for the radiocarbon samples are shown in Table C.1. All samples were wood charcoal; three were live oak (Quercus fusiformis) and one was mesquite (Prosopis glandulosa).

Results from flotation samples are shown in Table C.2 and Table C.3. Uncarbonized flora, shown in Table C.2, are modern plants that were either present in the soil prior to excavation (e.g., roots, and rootlets) or made their way into archeological units during excavation (e.g., leaves). Several lines of argument and evidence support this interpretation. First, excavations the site did not indicate extraordinary preservation of organic materials. Fresh plant remains are common on open archeological sites in North America but they usually represent modern plants that have made their way into the soil either through their own dispersal mechanisms or by faunalturbation, floralturbation, or argilliturbation (Bryant 1985:51-52; Keepax 1977; Miksicek 1987:231-232). In all except the driest areas of North America, uncarbonized plant material on open-air sites can be assumed to be of modern origin unless compelling evidence suggests otherwise (Lopinot and Brussell 1982; Miksicek 1987:231). Second, the seeds present in uncarbonized form at 41SS164 are weedy taxa associated with disturbed areas such as roadsides. Finally, the lower sample contained fewer types of uncarbonized plants than did the upper sample, a situation consistent with entry of plants from the modern surface. Both live oak and a legume that is probably mesquite, present as leaves in the uncarbonized flora, were also recovered among the ancient flora from the site in carbonized form. The finding should be taken to indicate the continuity of some common tree species in the Richland Creek area during the Holocene.

As shown in Table C.3, all carbonized plant remains from flotation samples consisted of wood charcoal. In addition to the live oak and mesquite that were also present in the radiocarbon samples, the flotation yielded two fragments of wood charcoal from a white group oak. These oaks, most readily recognizable in the field by leaves with rounded lobes, produce acorns in a single season rather than the two seasons required for acorn production by red oaks (Diggs et al. 1999:712-713). For this reason, their acorns tend to have lower tannin levels than red oak acorns (Tull 1987:102-103). Post oak (Quercus stellata) is the most common white oak in the eastern two-thirds of Texas and is common throughout that part of the state. Bur oak (Q. macrocarpa) prefers habitats along streams and would be another likely candidate for the wood charcoal at 41SS164. A third white oak known in San Saba County, Bigelow's oak (Q. sinuata var. breviloba), grows in rockier areas. (Diggs et al. 1999; Turner et al. 2003).

Oak wood is notable for its high quality as a firewood. With specific gravities ranging from about 0.60 to 0.90 , oaks have some of the highest densities in among North American woods (Hoadley 1990). Since specific gravity relates directly to burning temperature (Graves 1919), oak wood burns hot and produces long-lasting coals. Mesquite was present in central Texas prior to settlement by agriculturalists, although it was less common than today (Diggs et al. 1999:688). (Mark Raab [1983] argues from pollen evidence that mesquite is a historic intruder to some parts of Texas, but he explicitly limits his conclusion to the north-central part of the state.) Mesquite has a 
Table C.1. Radiocarbon Samples from 41SS164

$\begin{array}{rrlrr}\text { Bag } & \text { Lot Botanical Name } & \text { Common name } & \text { Count } & \text { Weight (g) } \\ 5 & 6 \text { Quercus fusiformis } & \text { Live oak } & 1 & 0.03 \\ 9 & \text { 10 Quercus fusiformis } & \text { Live oak } & 1 & 0.10 \\ 16 & \text { 19 Prosopis glandulosa Mesquite } & 1 & 0.19 \\ 19 & \text { 24 Quercus fusiformis } & \text { Live oak } & 1 & 0.06\end{array}$


Table C.2. Uncarbonized Botanical Remains Recovered Through Flotation Processing at $41 \mathrm{SS} 164$

Bag

Lot

Feature

Depth

Roots

Rootlets

Live oak leaves (Quercus fusiformis )

Legume leaves (cf. Prosopis glandulosa)

Grass seed (Poaceae)

Carpetweed seeds (Mollugo verticillata)

Indeterminable seed

Insects

Bone

Flakes
28

33

2

90 cmbd

Presence/Absence Presence/Absence

$\mathrm{X}$

$\mathrm{X}$

$\mathrm{X}$

$\mathrm{X} \quad \mathrm{X}$

$\mathrm{X}$

$\mathrm{X}$

$\mathrm{X}$

$\mathrm{X}$

$\mathrm{X}$

$\mathrm{X}$
29

34

2

$70 \mathrm{cmbd}$ $\mathrm{X}$

$\mathrm{X}$

$x$

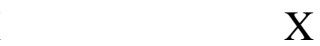

X $\quad X$

$\mathrm{X}$

$x$


Table C.3. Carbonized Botanical Remains Recovered Through Flotation Processing at $41 \mathrm{SS} 164$

Bag

Lot

Feature

Depth

Liters processed

Light fraction total

Contamination $>2 \mathrm{~mm}$

Residue $<2 \mathrm{~mm}$

Wood charcoal total

Live oak (Quercus fusiformis )

Oak, white group (Quercus subg. Quercus)

Mesquite (Prosopis glandulosa)
$28 \quad 29$

$33 \quad 34$

22

$90 \mathrm{cmbd} \quad 70 \mathrm{cmbd}$

\section{Count Weight (g) Count Weight (g) \\ 4 \\ 3}

1.22

0.75

0.55

0.43

0.64

0.31

$3 \quad 0.04$

1

0.01

$1 \quad 0.02$

$2 \quad 0.02$ 
specific gravity in the oak range, at around 0.70 , and has similar burning properties. Not everyone is partial to the distinctive odor produced by mesquite when it smokes, however.

\section{Summary}

Four radiocarbon samples were identified from 41SS164 and found to be live oak and mesquite wood charcoal. The two flotation samples yielded additional wood charcoal, including white group oak.

\section{References Cited}

Bryant, John A.

1985 Seed Physiology. The Institute of Biology's Studies in Biology No. 165. Edward Arnold, Ltd., London.

Davis, Linda W.

1993 Weed Seeds of the Great Plains: A Handbook for Identification. University Press of Kansas, Lawrence.

Diggs Jr., George M., Barney L. Lipscomb and Robert J. O'Kennon

1999 Shinners and Mahler's Illustrated Flora of North Central Texas. Second Printing, 2000, with minor corrections. ed. Illustrated Texas Floras Project. Botanical Research Institute of Texas, Fort Worth.

Graves, Henry S.

1919 The Use of Wood for Fuel. United States Department of Agriculture Bulletin Bulletin No. 753. United States Department of Agriculture, Washington, DC.

Hoadley, R. Bruce

1990 Identifying Wood: Accurate Results with Simple Tools. The Taunton Press, Newtown, Connecticut.

Keepax, Carole

1977 Contamination of archaeological deposits by seeds of modern origin with particular reference to the use of flotation machines. Journal of Archaeological Science 4:221-229.

Lopinot, Neal H. and David Eric Brussell

1982 Assessing Uncarbonized Seeds from Open-air Sites in Mesic Environments: An Example from Southern Illinois. Journal of Archaeological Science 9:95-108. 
Martin, Alexander C. and William D. Barkley

1961 Seed Identification Manual. University of California Press, Berkeley.

Miksicek, Charles H.

1987 Formation Processes of the Archaeobotanical Record. In Advances in Archaeological Method and Theory, Vol. 10, edited by Michael B. Schiffer, pp. 211-247. Academic Press, Inc.

Musil, Albina F.

1963 Identification of Crop and Weed Seeds Agriculture Handbook No. 219.

U.S. Department of Agriculture, Washington, D.C.

Panshin, A. J. and Carol de Zeeuw

1980 Textbook of Wood Technology: Structure, Identification, Properties, and Uses of the Commercial Woods of the United States and Canada. Fourth ed. McGraw-Hill Book Company, New York.

Raab, L. Mark

1983 Mesquite (Prosopis) Pollen as an Archeological Indicator of Recent Environments. Bulletin of the Texas Archeological Society 53(121-129).

Schopmeyer, C. S.

1974 Seeds of Woody Plants in the United States Agricultural Handbook No. 450. Forest Service, United States Department of Agriculture, Washington, DC.

Tull, Delena

1999 Edible and Useful Plants of Texas and the Southwest. University of Texas Press, Austin.

Turner, Billie L., Holly Nichols, Geoffrey Denny and Oded Doron 2003 Atlas of the Vascular Plants of Texas, Volume 1:Dicots. Sida, Botanical Miscellany, Number 24 Volume 1: Dicots. BRIT Press, Fort Worth. 


\section{Appendix D: Specimen InVentory}





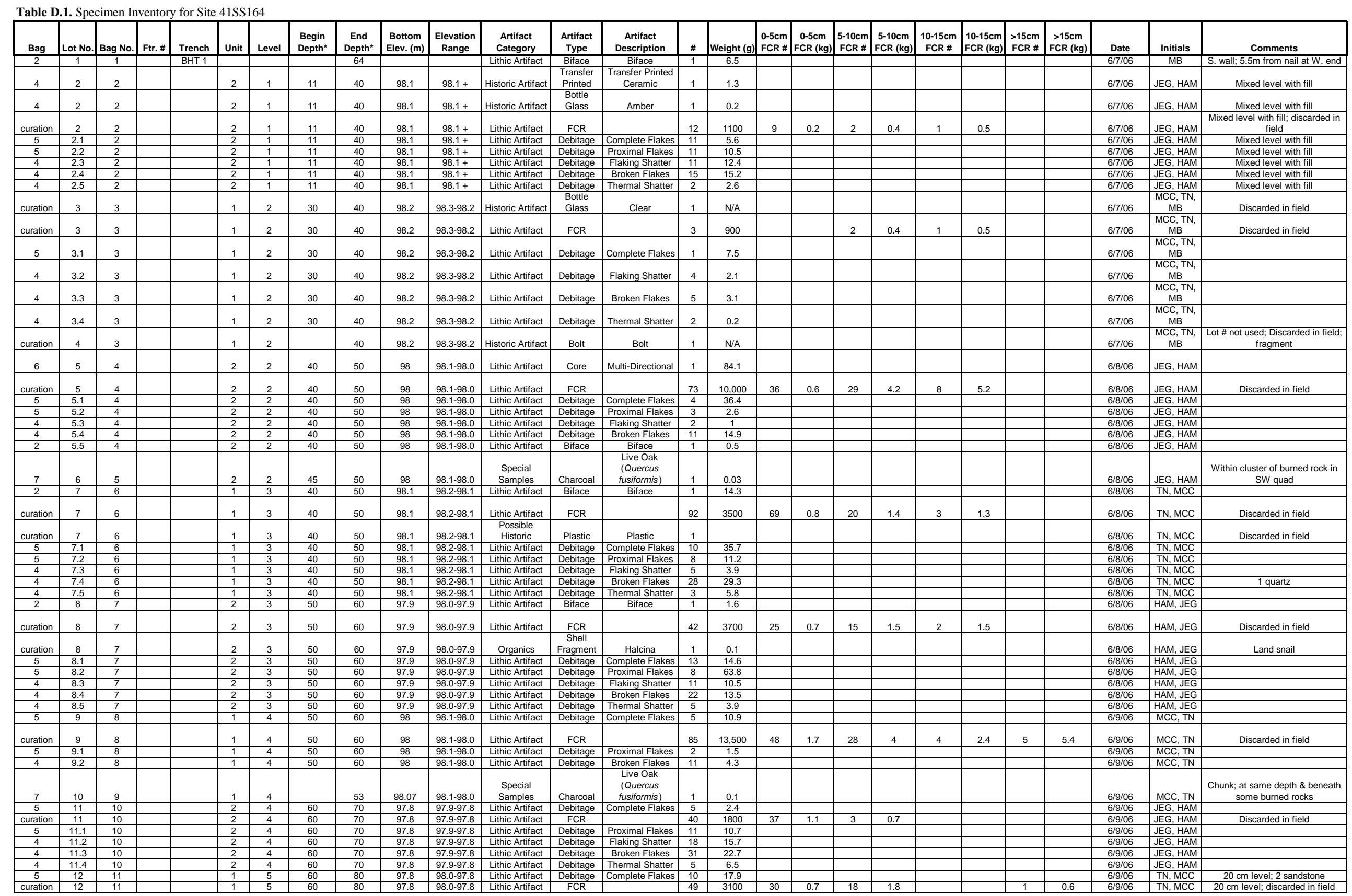

* Beginning and Ending Depths are given in centimeters below surface (cmbs) 


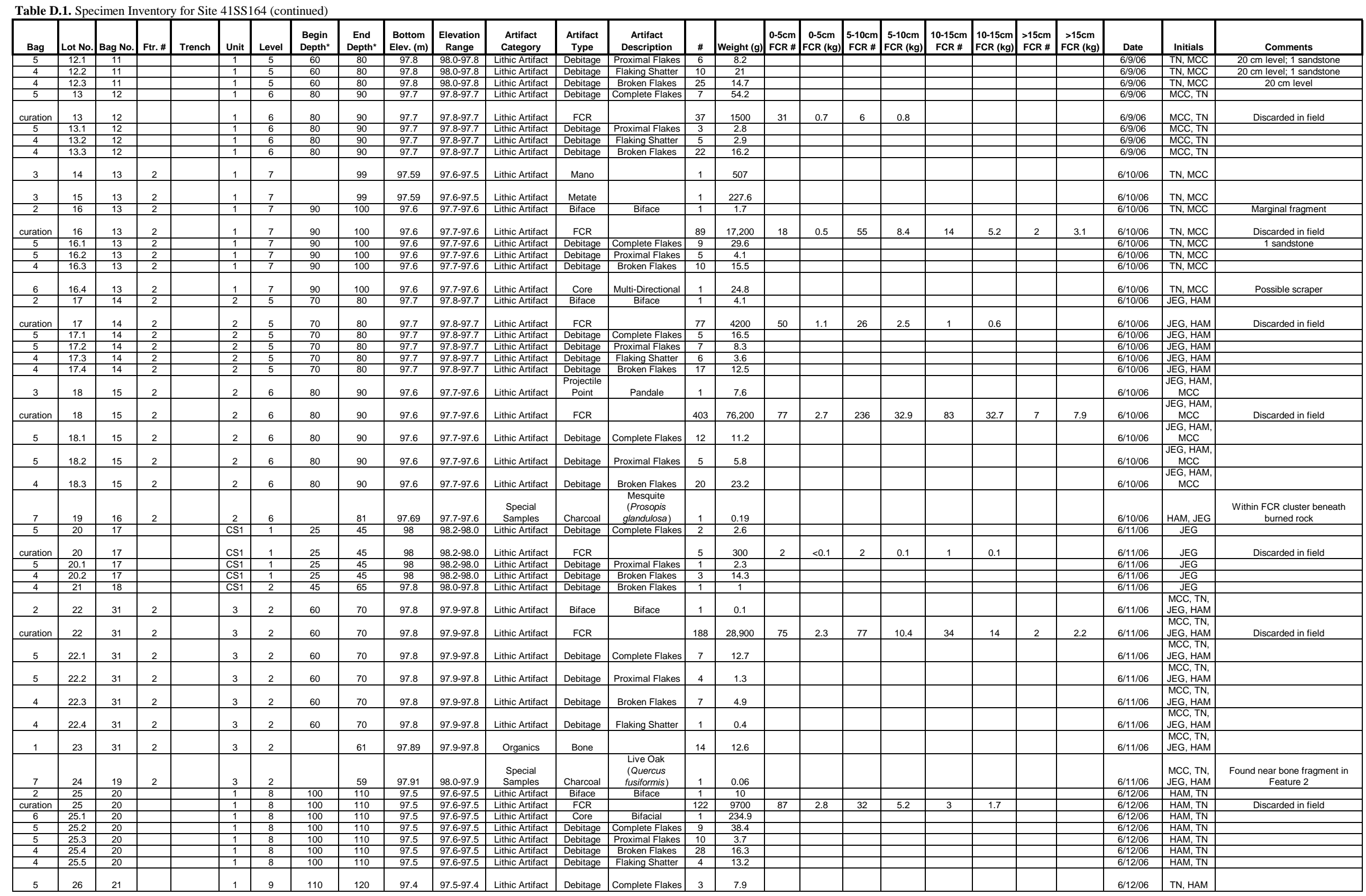

* Beginning and Ending Depths are given in centimeters below surface (cmbs) 
Table D.1. Specimen Inventory for Site 41SS164 (continued)

\begin{tabular}{|c|c|c|c|c|c|c|c|c|c|c|c|c|c|c|c|c|c|c|c|c|c|c|c|c|c|c|}
\hline Bag & Lot No. & Bag No. & Ftr.\# & Trench & Unit & Level & $\begin{array}{l}\text { Begin } \\
\text { Depth }^{*}\end{array}$ & $\begin{array}{c}\text { End } \\
\text { Depth }\end{array}$ & $\begin{array}{l}\text { Bottom } \\
\text { Elev. }(m)\end{array}$ & $\begin{array}{c}\text { Elevation } \\
\text { Range }\end{array}$ & $\begin{array}{l}\text { Artifact } \\
\text { Category }\end{array}$ & $\begin{array}{c}\text { Artifact } \\
\text { Type }\end{array}$ & $\begin{array}{c}\text { Artifact } \\
\text { Description }\end{array}$ & \# & Weight (g) & 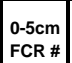 & $\left.\begin{array}{c}0-5 \mathrm{~cm} \\
\mathrm{FCR}(\mathrm{kg})\end{array}\right)$ & $\begin{array}{c}5-10 \mathrm{~cm} \\
\mathrm{FCR} \#\end{array}$ & $\left|\begin{array}{c}5-10 \mathrm{~cm} \\
\mathrm{FCR}(\mathrm{kg})\end{array}\right|$ & $\begin{array}{c}10-15 \mathrm{~cm} \\
\text { FCR\# }\end{array}$ & $\begin{array}{l}10-15 \mathrm{~cm} \\
\operatorname{FCR}(\mathrm{kg})\end{array} \mid$ & $\begin{array}{l}>15 \mathrm{~cm} \\
\mathrm{FCR} \#\end{array}$ & $\begin{array}{c}>15 \mathrm{~cm} \\
\operatorname{FCR}(\mathrm{kg})\end{array}$ & Date & Initials & Comments \\
\hline $\begin{array}{l}\text { curation } \\
\end{array}$ & \begin{tabular}{|l|}
26 \\
261
\end{tabular} & $\begin{array}{l}21 \\
21\end{array}$ & & & $\frac{1}{1}$ & $\begin{array}{l}9 \\
9\end{array}$ & $\frac{110}{110}$ & $\frac{120}{120}$ & $\begin{array}{l}97.4 \\
97.4\end{array}$ & $\begin{array}{l}97.5-97.4 \\
97.5-9.4 \\
\end{array}$ & $\begin{array}{l}\text { Lithic Artifact } \\
\text { Lithic Artifact }\end{array}$ & & Proximal Flakes & $\frac{54}{6}$ & \begin{tabular}{l|}
1700 \\
103
\end{tabular} & \begin{tabular}{|l|}
12 \\
\end{tabular} & 0.9 & \begin{tabular}{|l|}
42 \\
\end{tabular} & \begin{tabular}{l|l|}
0.8 \\
\end{tabular} & & & & & $\begin{array}{l}6 / 12 / 106 \\
6 / 1206 \\
\end{array}$ & $\begin{array}{ll}\text { TN, HAM } \\
\text { TN, HAM }\end{array}$ & Discarded in field \\
\hline$\frac{5}{4}$ & $\frac{26.1}{26.2}$ & $\frac{21}{21}$ & & & $\frac{1}{1}$ & $\frac{9}{9}$ & $\frac{710}{110}$ & $\frac{120}{120}$ & $\begin{array}{l}97.4 \\
97.4\end{array}$ & $\begin{array}{l}\frac{97.5-9-9.4}{97.5-97.4} \\
\end{array}$ & $\frac{\text { Litnic Arrtiact }}{\text { Lithic Artifact }}$ & $\begin{array}{l}\text { Debitage } \\
\text { Debitage }\end{array}$ & $\begin{array}{l}\text { Proximan Flakes } \\
\text { Brokelakes }\end{array}$ & $\frac{6}{9}$ & $\frac{10.3}{21}$ & & & & & & & & & $\frac{6 / 12 / 1 / 166}{6 / 12 / 16}$ & $\frac{\text { TN, HAM }}{\text { TN, HAM }}$ & \\
\hline $\begin{array}{l}4 \\
4\end{array}$ & $\frac{26.3}{27}$ & $\begin{array}{l}21 \\
22\end{array}$ & & & $\begin{array}{ll}1 \\
C S 1\end{array}$ & $\begin{array}{l}9 \\
3\end{array}$ & $\frac{110}{65}$ & $\frac{120}{85}$ & $\begin{array}{l}97.4 \\
97.6\end{array}$ & $\begin{array}{l}97.5-97.4 \\
97.8-97.6 \\
\end{array}$ & $\begin{array}{l}\text { Lithic Artifact } \\
\text { Lithic Artifact }\end{array}$ & $\begin{array}{l}\text { Debitage } \\
\text { Debitage }\end{array}$ & $\begin{array}{l}\text { Flaking Shatter } \\
\text { Broken Flakes }\end{array}$ & $\begin{array}{l}2 \\
1\end{array}$ & $\begin{array}{l}3.2 \\
0.2\end{array}$ & & & & & & & & & $\begin{array}{l}6 / 12 / 1 / 06 \\
6 / 12 / 106\end{array}$ & $\begin{array}{ll}\text { TN, HAM } \\
\text { JEG }\end{array}$ & \\
\hline curation & 27 & 22 & & & cs1 & 3 & 65 & 85 & 97.6 & 97.8-97.6 & Lithic Artifact & FCR & & 1 & 100 & 1 & $<0.1$ & & & & & & & $6 / 12 / 06$ & JEG & Discarded in field \\
\hline 5 & 28 & 23 & & & 1 & 10 & 120 & 130 & 97.3 & 97.4-97.3 & Lithic Artifact & Debitage & Complete Flakes & 1 & 0.2 & & & & & & & & & $6 / 12 / 106$ & HAM, TN & \\
\hline curation & 28 & 23 & & & 1 & 10 & 120 & 130 & 97.3 & 97.4-97.3 & Lithic Artifact & $\mathrm{FCR}$ & & 3 & 100 & 3 & $<0.1$ & & & & & & & $6 / 12 / 06$ & HAM, TN & Discarded in field \\
\hline $\begin{array}{ll}4 \\
5\end{array}$ & 28.1 & 23 & & & 1 & 10 & 120 & 130 & 97.3 & $\begin{array}{l}97.4-97.3 \\
7.797\end{array}$ & 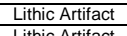 & $\begin{array}{l}\text { Debitage } \\
\text { Dahitarate }\end{array}$ & Broken Flakes & 4 & $\frac{1}{19}$ & & & & & & & & & $6 / 12 / 106$ & HAM, TN & \\
\hline 5 & 29 & 24 & & & CS1 & 5 & 105 & 125 & 97.2 & $\begin{array}{l}97.4-97.2 \\
\end{array}$ & Lithic Artifact & Debitage & Complete Flakes & 1 & $1 . .9$ & & & & & & & & & $6 / 12 / 106$ & JEG & \\
\hline curation & 30 & 25 & & & 4 & 1 & 90 & 100 & 97.5 & $97.6-97.5$ & Lithic Artifact & $\mathrm{FCR}$ & & 52 & 3400 & 32 & 0.9 & 19 & 1.9 & 1 & 0.6 & & & $6 / 12 / 06$ & MCC, JEG & $\begin{array}{c}\text { Continued excavation in western } \\
1 \times 1 m \text { of TU2 has been renamed } \\
\text { TU4; discarded in field }\end{array}$ \\
\hline 5 & 30.1 & 25 & & & 4 & 1 & 90 & 100 & 97.5 & 97.6-97.5 & Lithic Artifact & Debitage & Proximal Flakes & 5 & 3.1 & & & & & & & & & $6 / 12 / 06$ & MCC, JEG & $\begin{array}{l}\text { Continued excavatitin in western } \\
1 \times 1 \mathrm{~m} \text { of TU2 has been renamed } \\
\text { TU4 }\end{array}$ \\
\hline 4 & 30.2 & 25 & & & 4 & 1 & 90 & 100 & 97.5 & $97.6-97.5$ & Lithic Artifact & Debitage & Broken Flakes & 13 & 8.1 & & & & & & & & & $6 / 12 / 06$ & $\mathrm{MCC}, \mathrm{JEG}$ & $\begin{array}{c}\text { Continued excavation in western } \\
1 \times 1 \mathrm{~m} \text { of TU2 has been renamed } \\
\text { TU4 }\end{array}$ \\
\hline 4 & 30.3 & 25 & & & 4 & 1 & 90 & 100 & 97.5 & $97.6-97.5$ & Lithic Artifact & Debitage & Flaking Shatter & 4 & 2.1 & & & & & & & & & $6 / 12 / 06$ & MCC, JEG & 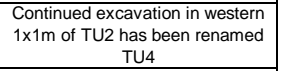 \\
\hline$\frac{4}{5}$ & $\frac{30.3}{31}$ & $\frac{25}{26}$ & & & $\frac{4}{1}$ & $\frac{1}{11}$ & $\frac{90}{130}$ & 100 & $\begin{array}{l}97.5 \\
97.2 \\
\end{array}$ & $\begin{array}{l}\frac{91.6-9-1.5}{97 .-97.2} \\
\end{array}$ & $\begin{array}{l}\text { Litnic Antract } \\
\text { Lithic Artifact }\end{array}$ & $\begin{array}{l}\text { Denorage } \\
\text { Debitage }\end{array}$ & $\begin{array}{l}\text { Hakning snatuer } \\
\text { Complete Flakes }\end{array}$ & $\frac{4}{2}$ & $\frac{2.1}{10.7}$ & & & & & & & & & $6 / 6 / 12106$ & TN, HAM & \\
\hline 4 & 31.2 & 26 & & & 1 & 11 & 130 & 140 & 97.2 & $97.3-97.2$ & Lithic Artifact & Debitage & Broken Flakes & 1 & 0.7 & & & & & & & & & $6 / 12 / 106$ & TN, HAM & \\
\hline 1 & 32 & 27 & & ВНT 1 & & & & $\begin{array}{l}130 \\
\text { (cmbs) }\end{array}$ & & & Lithic Artifact & Flake Tool & Retouched Flake & 1 & 89 & & & & & & & & & $6 / 12 / 06$ & MB & S. wall $5.67 \mathrm{~m}$ from $W$. trench wall \\
\hline 2 & 33 & 28 & 2 & & 2 & 6 & & 90 & 97.6 & 97.7-97.6 & $\begin{array}{l}\text { Special } \\
\text { Samples }\end{array}$ & $\begin{array}{l}\text { Feature } \\
\text { Matrix }\end{array}$ & Bone & 4 & $<0.1$ & & & & & & & & & $6 / 12 / 06$ & TN & $\begin{array}{c}\begin{array}{c}\text { Feature } 2 \text { soil from pedestal; E. } \\
\text { half of unit } 2\end{array} \\
\end{array}$ \\
\hline 2 & 33 & 28 & 2 & & 2 & 6 & & 90 & 97.6 & $97.7-97.6$ & $\begin{array}{l}\text { Special } \\
\text { Samples }\end{array}$ & $\begin{array}{l}\text { Feature } \\
\text { Matrix }\end{array}$ & Debitage & 1 & $<0.1$ & & & & & & & & & $6 / 12 / 06$ & TN & $\begin{array}{c}\text { Feature } 2 \text { soil from pedestal; E. } \\
\text { half of unit } 2\end{array}$ \\
\hline curation & 33 & 28 & 2 & & 2 & 6 & & 90 & 97.6 & $97.7-97.6$ & $\begin{array}{l}\text { Special } \\
\text { Samples }\end{array}$ & $\begin{array}{l}\text { Light } \\
\text { Fraction }\end{array}$ & $\begin{array}{l}\text { Live Oak } \\
\text { (Quercus } \\
\text { fusiformis) }\end{array}$ & 3 & 0.04 & & & & & & & & & $6 / 12 / 06$ & TN & $\begin{array}{l}\text { Not returned from analyst, Feature } \\
2 \text { soil from pedestal; } \text { E. half of unit } \\
\qquad 2\end{array}$ \\
\hline 2 & 33 & 28 & 2 & & 2 & 6 & & 90 & 97.6 & $97.7-97.6$ & $\begin{array}{l}\text { Special } \\
\text { Samples }\end{array}$ & $\begin{array}{l}\text { Light } \\
\text { Fraction } \\
\end{array}$ & $\begin{array}{l}\text { Oak, white group } \\
\text { (Quercus subg. } \\
\text { Quercus }\end{array}$ & 1 & 0.02 & & & & & & & & & $6 / 12 / 06$ & TN & $\begin{array}{c}\text { Feature } 2 \text { soil from pedestal; E. } \\
\text { half of unit } 2\end{array}$ \\
\hline 2 & 33 & 28 & 2 & & 2 & 6 & & 90 & 97.6 & $97.7-97.6$ & $\begin{array}{l}\text { Special } \\
\text { Samples }\end{array}$ & $\begin{array}{l}\text { Light } \\
\text { Fraction }\end{array}$ & \begin{tabular}{|l|} 
Mesquite \\
(Prosopis \\
glandulosa)
\end{tabular} & 2 & 0.02 & & & & & & & & & $6 / 12 / 06$ & TN & $\begin{array}{l}\text { Feature } 2 \text { soil from pedestal; E. } \\
\text { half of unit } 2\end{array}$ \\
\hline na & 33 & 28 & 2 & & 2 & 6 & & 90 & 97.6 & $97.7-97.6$ & $\begin{array}{l}\text { Special } \\
\text { Samples }\end{array}$ & $\begin{array}{l}\begin{array}{c}\text { Feature } \\
\text { Matrix }\end{array} \\
\end{array}$ & Roots & \multicolumn{2}{|c|}{ 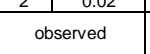 } & & & & & & & & & $6 / 12 / 06$ & TN & $\begin{array}{l}\text { Feature } 2 \text { soil from pedestal; } \\
\text { half of unit } 2\end{array}$ \\
\hline na & 33 & 28 & 2 & & 2 & 6 & & 90 & 97.6 & 97.7-97.6 & $\begin{array}{l}\text { Special } \\
\text { Samples }\end{array}$ & $\begin{array}{l}\text { Feature } \\
\text { Matrix }\end{array}$ & Rootlets & \multicolumn{2}{|c|}{ observed } & & & & & & & & & $6 / 12 / 06$ & TN & $\begin{array}{l}\text { Feature } 2 \text { soil from pedestal; } E . \\
\text { half of unit } 2\end{array}$ \\
\hline na & 33 & 28 & 2 & & 2 & 6 & & 90 & 97.6 & $97.7-97.6$ & $\begin{array}{l}\text { Special } \\
\text { Samples }\end{array}$ & $\begin{array}{l}\text { Feature } \\
\text { Matrix }\end{array}$ & $\begin{array}{c}\text { Live Oak leaves } \\
\text { (1uercus } \\
\text { fusiformis) }\end{array}$ & \multicolumn{2}{|c|}{ observed } & & & & & & & & & $6 / 12 / 06$ & TN & $\begin{array}{l}\text { Feature } 2 \text { soil from pedestal; } E . \\
\text { half of unit } 2\end{array}$ \\
\hline na & 33 & 28 & 2 & & 2 & 6 & & 90 & 97.6 & $97.7-97.6$ & $\begin{array}{l}\text { Special } \\
\text { Samples }\end{array}$ & $\begin{array}{l}\text { Feature } \\
\text { Matrix }\end{array}$ & $\begin{array}{l}\text { Legume leaves } \\
\text { (ct. Prosopis } \\
\text { glandulosa) }\end{array}$ & \multicolumn{2}{|c|}{ observed } & & & & & & & & & 6/12/06 & TN & $\begin{array}{l}\text { Feature } 2 \text { soil from pedestal; } E \text {. } \\
\text { half of unit } 2\end{array}$ \\
\hline na & 33 & 28 & 2 & & 2 & 6 & & 90 & 97.6 & $97.7-97.6$ & $\begin{array}{l}\text { Special } \\
\text { Samples }\end{array}$ & $\begin{array}{l}\text { Feature } \\
\text { Matrix }\end{array}$ & $\begin{array}{l}\text { Grass seed } \\
\text { (Poaceae) }\end{array}$ & \multicolumn{2}{|c|}{ observed } & & & & & & & & & $6 / 12 / 06$ & TN & $\begin{array}{c}\text { Feature } 2 \text { soil from pedestal; E. } \\
\text { half of unit } 2\end{array}$ \\
\hline na & 33 & 28 & 2 & & 2 & 6 & & 90 & 97.6 & $97.7-97.6$ & $\begin{array}{l}\text { Special } \\
\text { Samples }\end{array}$ & $\begin{array}{l}\text { Feature } \\
\text { Matrix }\end{array}$ & $\begin{array}{l}\text { Carpetweed } \\
\text { seeds (Mollugo } \\
\text { verticillata) }\end{array}$ & \multicolumn{2}{|c|}{ observed } & & & & & & & & & $6 / 12 / 06$ & TN & $\begin{array}{c}\text { Feature } 2 \text { soil from pedestal; E. } \\
\text { half of unit } 2\end{array}$ \\
\hline na & 33 & 28 & 2 & & 2 & 6 & & 90 & 97.6 & $97.7-97.6$ & $\begin{array}{l}\text { Special } \\
\text { Samples }\end{array}$ & $\begin{array}{l}\text { Feature } \\
\text { Matrix }\end{array}$ & Insects & \multicolumn{2}{|c|}{ observed } & & & & & & & & & 6/12/06 & TN & $\begin{array}{l}\text { Feature } 2 \text { soil from pedestal; } E \text {. } \\
\text { half of unit } 2\end{array}$ \\
\hline na & 34 & 29 & 2 & & 3 & 2 & & 70 & 97.8 & 97.9-97.8 & $\begin{array}{l}\text { Special } \\
\text { Samples }\end{array}$ & $\begin{array}{l}\text { Feature } \\
\text { Matrix }\end{array}$ & Roots & \multicolumn{2}{|c|}{ observed } & & & & & & & & & 6/12/06 & TN & Feature 2 soil from pedestal \\
\hline 2 & 34 & 29 & 2 & & 3 & 2 & & 70 & 97.8 & 97.9-97.8 & $\begin{array}{l}\text { Oadmies } \\
\text { Special } \\
\text { Samples }\end{array}$ & $\begin{array}{l}\text { Neatur } \\
\text { Feature } \\
\text { Matrix }\end{array}$ & Bone & 4 & $<0.1$ & & & & & & & & & $6 / 12 / 06$ & TN & Feature 2 soil from pedestal \\
\hline 2 & 34 & 29 & 2 & & 3 & 2 & & 70 & 97.8 & $97.9-97.8$ & $\begin{array}{l}\text { Special } \\
\text { Samples }\end{array}$ & $\begin{array}{l}\text { Feature } \\
\text { Matrix }\end{array}$ & Debitage & 3 & 0.7 & & & & & & & & & $6 / 12 / 06$ & TN & Feature 2 soil from pedestal \\
\hline
\end{tabular}

* Beginning and Ending Depths are given in centimeters below surface (cmbs) 
Table D.1. Specimen Inventory for Site 41SS164 (continued)

\begin{tabular}{|c|c|c|c|c|c|c|c|c|c|c|c|c|c|c|c|c|c|c|c|c|c|c|c|c|c|c|}
\hline Bag & Lot No. & Bag No. & Ftr.\# & Trench & Unit & Level & $\begin{array}{l}\text { Begin } \\
\text { Depth }^{*}\end{array}$ & $\begin{array}{c}\text { End } \\
\text { Depth* }\end{array}$ & $\begin{array}{l}\text { Bottom } \\
\text { Elev. }(m)\end{array}$ & $\begin{array}{c}\text { Elevation } \\
\text { Range }\end{array}$ & $\begin{array}{l}\text { Artifact } \\
\text { Category }\end{array}$ & $\begin{array}{c}\text { Artifact } \\
\text { Type }\end{array}$ & $\begin{array}{c}\text { Artifact } \\
\text { Description }\end{array}$ & \# & Weight (g) & $\begin{array}{l}0-5 \mathrm{~cm} \\
\text { FCR \# }\end{array}$ & $\begin{array}{c}0-5 \mathrm{~cm} \\
\mathrm{FCR}(\mathrm{kg})\end{array} \mid$ & $\begin{array}{r}5-10 \mathrm{~cm} \\
\text { FCR \# }\end{array}$ & $\begin{array}{l}5-10 \mathrm{~cm} \\
\mathrm{FCR}(\mathrm{kg})\end{array}$ & $\begin{array}{c}10-15 \mathrm{~cm} \\
\text { FCR \# }\end{array}$ & $\left|\begin{array}{l}10-15 \mathrm{~cm} \\
\mathrm{FCR}(\mathrm{kg})\end{array}\right|$ & $\begin{array}{l}>15 \mathrm{~cm} \\
\text { FCR } \#\end{array}$ & $\begin{array}{l}>15 \mathrm{~cm} \\
\mathrm{FCR}(\mathrm{kg})\end{array}$ & Date & Initials & Comments \\
\hline na & 34 & 29 & 2 & & 3 & 2 & & 70 & 97.8 & $97.9-97.8$ & $\begin{array}{l}\text { Special } \\
\text { Samples }\end{array}$ & $\begin{array}{l}\text { Feature } \\
\text { Matrix }\end{array}$ & Rootlets & \multicolumn{2}{|c|}{ observed } & & & & & & & & & $6 / 12 / 06$ & TN & Feature 2 soil from pedestal \\
\hline na & 34 & 29 & 2 & & 3 & 2 & & 70 & 97.8 & $97.9-97.8$ & $\begin{array}{l}\text { Special } \\
\text { Samples }\end{array}$ & $\begin{array}{l}\begin{array}{l}\text { Feature } \\
\text { Matrix }\end{array} \\
\end{array}$ & $\begin{array}{l}\text { Legume leaves } \\
\text { (cf. Prosopis } \\
\text { glandulosa) }\end{array}$ & \multicolumn{2}{|c|}{ observed } & & & & & & & & & $6 / 12 / 06$ & TN & Feature 2 soil from pedestal \\
\hline na & 34 & 29 & 2 & & 3 & 2 & & 70 & 97.8 & $97.9-97.8$ & $\begin{array}{l}\text { Special } \\
\text { Samples }\end{array}$ & $\begin{array}{l}\text { Feature } \\
\text { Matrix }\end{array}$ & $\begin{array}{l}\text { Carpetweed } \\
\text { seeds (Mollugo } \\
\text { verticillata) }\end{array}$ & \multicolumn{2}{|c|}{ observed } & & & & & & & & & $6 / 12 / 06$ & TN & Feature 2 soil from pedestal \\
\hline na & 34 & 29 & 2 & & 3 & 2 & & 70 & 97.8 & $97.9-97.8$ & $\begin{array}{l}\text { Special } \\
\text { Samples }\end{array}$ & $\begin{array}{l}\text { Feature } \\
\text { Matrix }\end{array}$ & $\begin{array}{l}\text { Indeterminable } \\
\text { seed }\end{array}$ & \multicolumn{2}{|c|}{ observed } & & & & & & & & & $6 / 12 / 06$ & TN & Feature 2 soil from pedestal \\
\hline na & 34 & 29 & 2 & & 3 & 2 & & 70 & 97.8 & $97.9-97.8$ & $\begin{array}{l}\text { Special } \\
\text { Samples }\end{array}$ & $\begin{array}{c}\text { Feature } \\
\text { Matrix }\end{array}$ & Insects & \multicolumn{2}{|c|}{ observed } & & & & & & & & & $6 / 12 / 06$ & TN & Feature 2 soil from pedestal \\
\hline curation & 34 & 29 & 2 & & 3 & 2 & & 70 & 97.8 & $97.9-97.8$ & $\begin{array}{l}\text { Special } \\
\text { Samples }\end{array}$ & $\begin{array}{l}\text { Light } \\
\text { Fraction }\end{array}$ & $\begin{array}{l}\text { Live Oak } \\
\text { (Quercus } \\
\text { fusiformis) }\end{array}$ & 1 & 0.01 & & & & & & & & & $6 / 12 / 06$ & TN & $\begin{array}{l}\text { Not returned from analyst, Feature } \\
2 \text { soil from pedestal }\end{array}$ \\
\hline$\frac{2}{5}$ & $\frac{34}{35}$ & $\frac{29}{30}$ & 2 & & $\frac{3}{4}$ & $\frac{2}{2}$ & 100 & $\frac{70}{110}$ & $\begin{array}{l}97.8 \\
97.4\end{array}$ & $\begin{array}{l}97.9-97.8 \\
97.5-97.4\end{array}$ & $\begin{array}{c}\text { Special } \\
\text { Samples } \\
\text { Lithic Artifact }\end{array}$ & $\begin{array}{l}\text { Light } \\
\text { Fraction } \\
\text { Debitage }\end{array}$ & $\begin{array}{c}\text { Mescuute } \\
\text { (Prosopis } \\
\text { glandulusa) } \\
\text { Proximal Flakes }\end{array}$ & $\frac{1}{2}$ & 0.01 & & & & & & & & & $\begin{array}{l}6 / 12 / 06 \\
6 / 13 / 06\end{array}$ & $\begin{array}{c}\text { TN } \\
\text { JEG, HAM }\end{array}$ & Feature 2 soil from pedestal \\
\hline curation & 35 & 30 & & & 4 & 2 & 100 & 110 & 97.4 & $97.5-97.4$ & Lithic Artifact & FCR & & 8 & 200 & 8 & 0.2 & & & & & & & $6 / 13 / 06$ & JEG. HAM & Discarded in field \\
\hline 4 & 35.1 & 30 & & & 4 & 2 & 100 & 110 & 97.4 & $97.5-97.4$ & Lithic Artifact & Debitage & Broken Flakes & 6 & 5.4 & & & & & & & & & $6 / 13 / 1 / 06$ & JEG, HAM & \\
\hline 6 & 36 & 32 & & BHT 1 & & & & $\begin{array}{c}126 \\
\text { (cmbs) }\end{array}$ & & & Lithic Artifact & Core & Multi-Directional & 1 & 82.5 & & & & & & & & & $6 / 13 / 06$ & $\mathrm{MB}$ & $7.35 \mathrm{~m} \mathrm{~W}$. wall \\
\hline 1 & 37 & 33 & & $B \mathrm{HT}_{1}$ & & & & 120 & & & Lithic Artifact & Flake Tool & Betouched Flake & 1 & 85 & & & & & & & & & $6 / 13306$ & $\mathrm{MB}$ & $6.25 \mathrm{~m}$ W wall \\
\hline curation & na & na & & BHT 1 & & & & & 98.1 & & Historic Artifact & Metal & Iron Bar & 1 & & & & & & & & & & $6 / 12 / 06$ & $\mathrm{MB}$ & $\begin{array}{l}\text { S. wall; } 12.5 \mathrm{~m} \text { from W. trench wall; } \\
\text { iron bar w/ hole in one end; not } \\
\text { collected }\end{array}$ \\
\hline curation & na & $m$ & & BHT 1 & & & & & 977 & & Histric Artifont & Metal & Nail & 1 & & & & & & & & & & $6 / 1206$ & $\mathrm{MB}$ & S. wall, $0.65 \mathrm{~m}$ from W. trench wall \\
\hline
\end{tabular}

